

\section{HARVARD UNIVERSITY.}

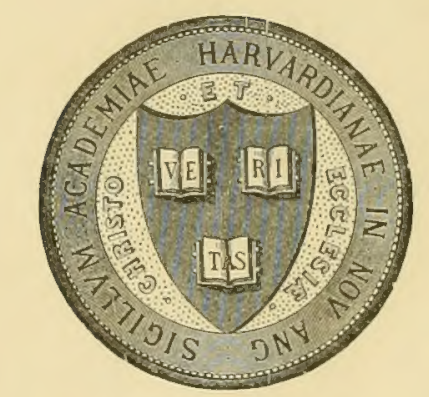

\section{LIRRARY}

$$
\text { OF THE }
$$

MUSEUM OF COMPARATIVE ZOÖLOGY.

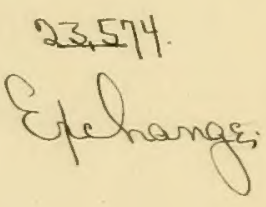

Slaryg.1904 


$\lambda$ 

DEPARTMENT OF THE INTERIOR

\section{MONOGRAPHS}

OF THE

\section{Uniteid States Geological Survey}

$$
\text { VOLUME XLII }
$$

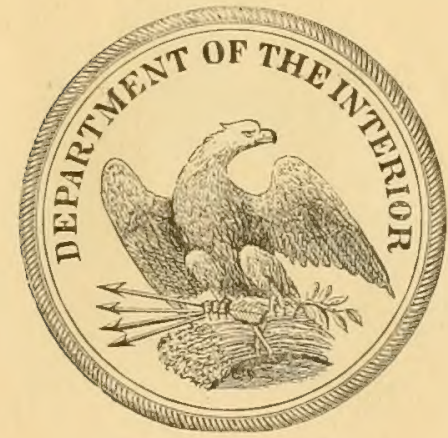

W A SHINGTON

GOVERNMENT PRINTING OFFICE 1903 

UNITED STATES GEOLOGICAL SURVEY

CHARLES D. WALCOTT, DIRECTOR

\section{THE}

\section{CARBONIFEROUS AWIONOIDS OF MIIERICA}

BY

\section{JAMES PERRIN SMITH}

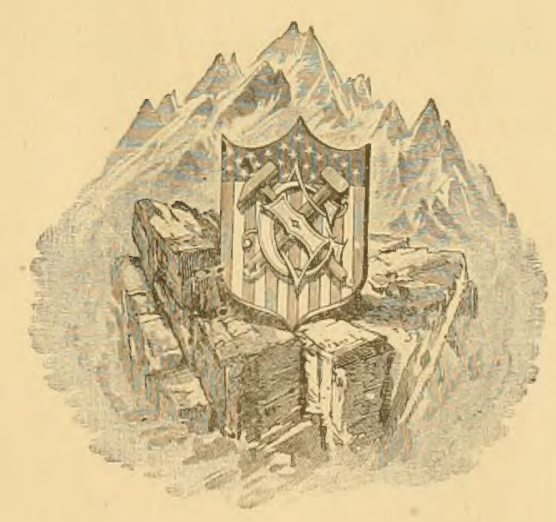

W A SH I T TON

$$
\begin{gathered}
\text { GOVERNMENT PRINTING OFFICE } \\
1903
\end{gathered}
$$




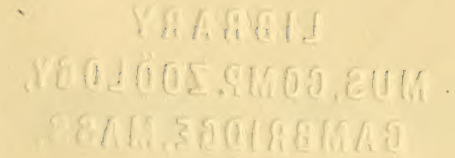




\section{CONTENTS.}

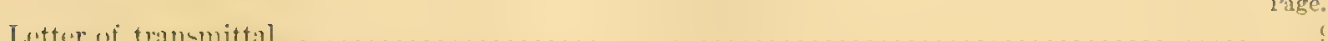

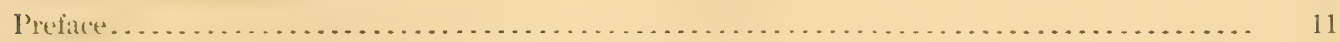

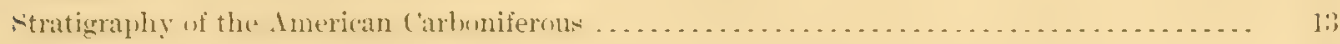

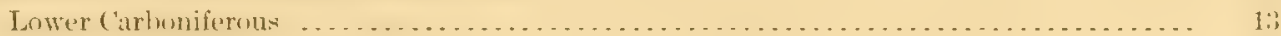

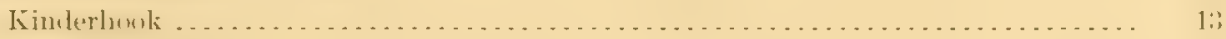

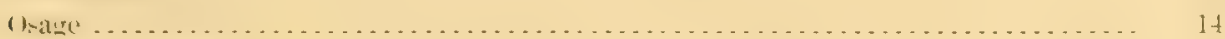

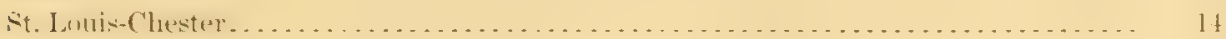

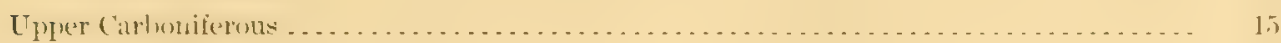

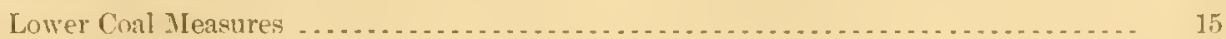

Middle Coal Measures . . . . . . . .

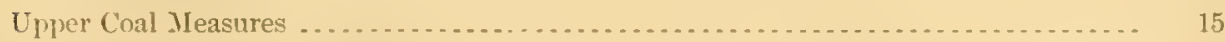

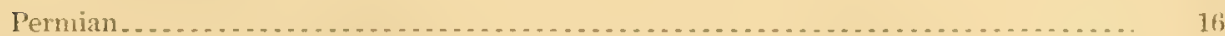

Cormelation table of the (arbmiferme . . . . . . . . . . . . . . . . . . . . . . . .

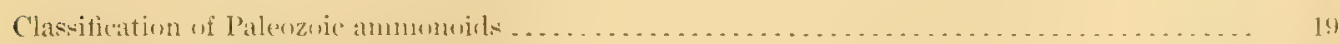

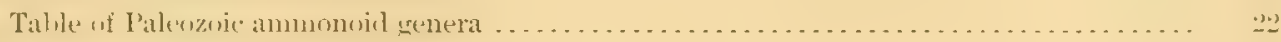

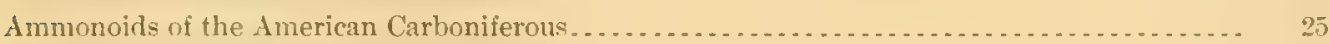

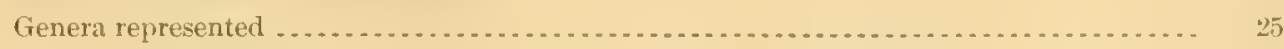

Table of occurrence of ammonoid genera in the American Carboniferous . . . . . . . . . . . . 27

Table of species described . . . . . . . .

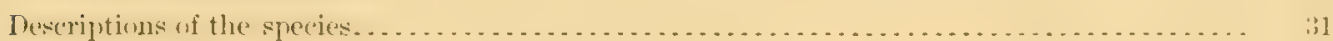

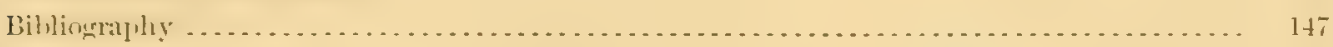

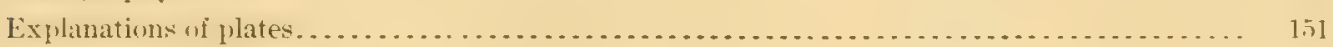

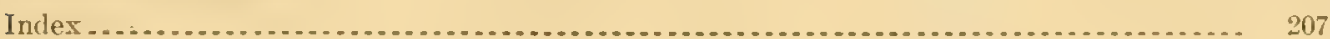





\section{ILLUSTRATIONS.}

Prate' I. Phylogenic table of the Paleozoic ammonoids . . . . . . . . . . . . . . . . . . . . . .

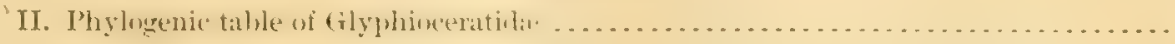

III. Figs. 1, 2, Schistoceras hildrethi Morton; figs. 3-13, Shumardites simondsi Smith ......

IV. Figs. 1-3, Gonioloboceras goniolobum Meek; figs. 4-8, Gastrioceras kingi Hall and Whitfield; figs. 9-11, Paralegoceras baylorense White; figs. 12-14, Paralegoceras

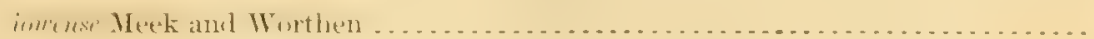

V. Figs. 1 and 2, Prionoceras ? Lrounense Miller; figs. 3 and 4, Muensteroceras? indianense Miller; figs. 5-7, Irolecanites? compactus Meek and Worthen; figs. 8-10, Gastrioceras nolinense Cox; fig. 11, Nomismoceres ? monroense WTorthen.....................

VI. Fig. 1, Gastrioceras globulosum Meek and Worthen; figs. 2-5, Goniatites lunatus Miller and Gurley; figs. 6-8, Prolecanites louisianensis Rowley; figs. 9-11, Bactrites car-

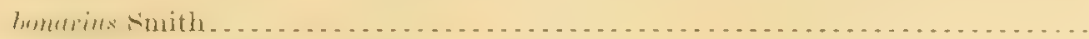

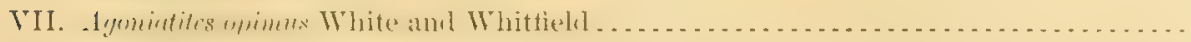

VIII. Fig. 1, Schistoceras missouriense Miller and Faber; figs. 2 and 3, Aganides? sciotoensis Miller and Faber; firs. 4 and 5, Prolecrnites greenii Miller; figs. 6 and 7, Gastrioceres occidentale Miller and Faber; figs. 8 and 9, Gonioloboceras ? limatum Jiller and Faber; figs. 10 and 11, Glyphioceras leviculum Hiller and Faber.................

IX. Figs. 1-3, Gastrioceras compressum Hyatt; figs. 4-7, Paralegoceras iowense Meek and

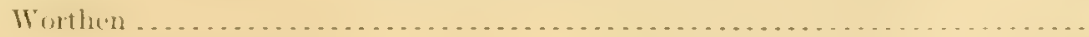

X. Figs. 1-11, Goniatites striatus Sowerby; figs. 12-16, Goniatifes crenistria Phillips; figs.

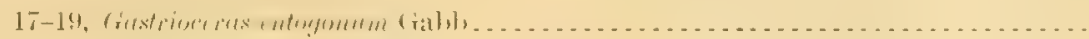

l'age

$\because 2$ is 151

1 ini 15x 160 162 16.4 Itit $16 s$

XI. Figs. 1-1, Gustrioceras carbonarium von Buch; figs. 5-7, Pronorites siebenthaii Smith;

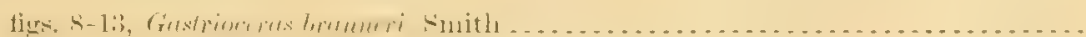

II. Figs. 1 and 2, Pronorites maxpermicus Karpinsky; fig. 3, Pronorites cyclolobus Phillips; figs. +-9, Paralegoceras neusomi Smith; fig. 10, Glyphioceras diadema Goldfuss; fig. 11, Tomoceras retrorsum von Buch; figs. 12-15, Pronorites cyclolobus Phillips var.

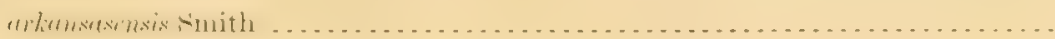

XIII. Figs. 1-5, Ironorites cyclololus Phillips; figs. 6-15, Gastrioceras listeri Martin. .......

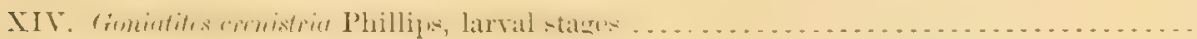

XV. Goniatites crenistria Phillips, development from adolescence to maturity ..........

XVI. Fig. 1, Goniatites crenistria I'hillips, development of the septa; fig. 2, Gastrioceras excelsum Meek; fig. 3, Muensteroceras parallelun Hall; figs. $1-5$, Pericyclus Wairi Miller and Gurley; figs. 6-8, Milleroceras parrishi Miller and Gurley; figs. 9-11, Veoicacera. elkhomense Miller and Gurley; figs. 12-14; Gastrioceras montgomeryense Niller and Gurley; figs. 15-17, Schistoceras fultonense Miller and Gurley; fig. 18, Prolecanites lyoni Meek and Worthen; fig. 19, Aganides rotatorius de Koninck; tig. 20, Pericyclus kochi Holzapfel; tig. 21, Popanocerts jurkeri Heilurin. 
Prate XVIT. Fig. 1, Goniatites kentuchiensis Miller; figs. 2-5, Goniatites nerwomi Smith; figs. 6-8, Page. Gastrioceras illinoisense Miller and Gurley; figs. 9-11, Gastrioceras kansasense Miller and Gurley; figs. 12-14, Goniatites greencastlensis Miller and Gurley; figs. 15-17, Gastrioceras subcavm Miller and Gurley; figs. 18-20, Aganides jessiex Miller and rurley . . . . . . . . . . . . . . . . . . . . . . . . . . . . .

IVIII. Glyphioceras caly.x Phillips, development from early larval stage to maturity.....

XIX. Figs. 1-2, Muensieroceras paralletum Hall; figs. 3-8, Muensteroceras oweni Hall; figs. 9-11, Prolecanites lyoni Meek and Worthen; figs. 12-14, Aganides rotatorius de Koninck .............................................

XX. Figs. 1-8, Schistoceres hyatti Smith; figs. 9-11, Gonioloboceras welleri Smith; figs.

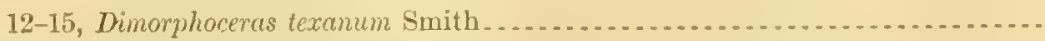

XXI. Figs. 1-6, Gonioloboceras welleri Smith; figs. 7-9, Gastrioceras globulosum Meek and Worthen; figs. 10-13, Schistoceras hyatt Smith; figs. 14-16, Popanoceras ganti Smith; figs. 17-19, Agathiceras ciscoense Smith; figs. 20-22, Schuchertiles

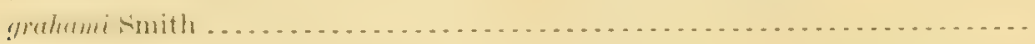

XXII. Figs. 1-3, Wedlicottia copei White; figs. 4-8, Wagenoceras cumminsi White; figs.

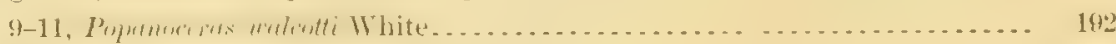

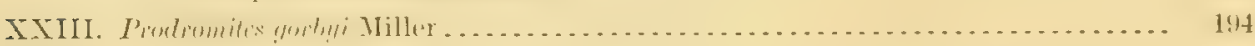

XXIV. Figs. 1-4, I'rolecaniles gurleyi Smith; figs. 5-7, Aganides discoidalis Smith; figs. S-12, Muensteroceras osagense Swallow; figs. 13-20, Gastrioceras velleri Smith....

XXV. Figs. 1 and 2, Prodromites gorbyi Miller; tigs. 3 and 4, I'rodromites promaturus Smith and Weller; fig. 5, Hedenstromia mojsisocicsi Diener; tigs. 6-8 Prodromites

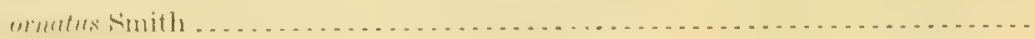
182 184

XXVI. Figs. 1-5, Goniatiles crenistric Phillips; figs. 6-13, Goniatites striatus Sowerby; figs. 14-18, Goniatites subcircularis Miller............................ 20.

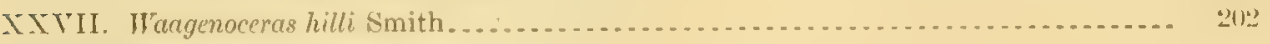

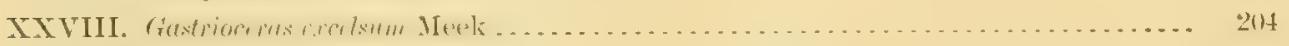

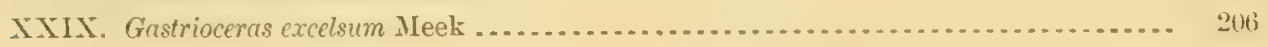




\title{
LETTER OF 'TRANSMITTAL.
}

\author{
Stanford University, Cal., May 1\%, 1901.
}

SIR: I have the honor to transmit herewith the manuscript and drawings for a paper entitled The Carboniferous Ammonoids of America, in which all the Carboniferous ammonoid genera and species known in America are listed, described, and, where possible, figured.

A phylogenic classification of the Paleozoic ammonoids is attempted, which, it is hoperl, will prove useful to students of systematic paleontology. Very respectfully,

Hon. Charles D. Walcott, James Perrin Sirth.

Director United States Geological Survey. 



\section{PRE A C E}

A number of years ago the writer began his studies of American

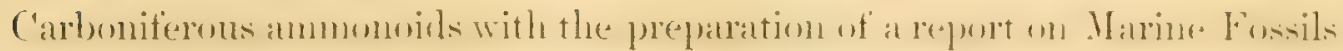
from the Coal Measures of Arkansas for the geological survey of Arkansas, unler the directorship of P'rof. John C. Branner, State geologist. 'This work has been continued uninteriuptedly since then in connection with the writer's studies in the cephalopods of the 'Trias.

In the prosecution of these studies the writer has spent much time in the field in Arkansas and 'Texas, and has had access to the material collected by the geological surveys of those two States.

The writer desires to make acknowledgment to the gentlemen named below for courtesies in the loan of specimens and for assistance in the prosecution of this work:

D1. John C. Branner, of Leland Stanford Junior University, formerly State geologist of Arkansas, for the opportunity of studying the collections of Carboniferous cephalopods made by the geological survey of Arkansas.

Dr. Stuart Weller, of the University of Chicago, for the opportunity of studying the Gurley collection (the richest in the United States in Carboniferous ammonoids), for the loan of specimens and drawings, and for much valuable assistance.

Prof. Alpheus Hyatt, for the lcan of specimens and for valuable advice and suggestions

Prof. Robert 'T'. Jackson, of Harvard University, for the loan of specimens.

Mr. Charles Schuchert, of the U. S. National MIuseum, for the use of specimens.

Messis. E. 'T' Dumble and W. F. Cummins, of the geological survey of 'T'exas, and Prof. F. W. Simonds, of the University of 'Texas, for the olportunity of sturlying the collections of the gerological survery and of the university.

IIr. G. A. Graham and Dr. Gant, of Graham, 'Tex., for the gift of valuable specimens. 



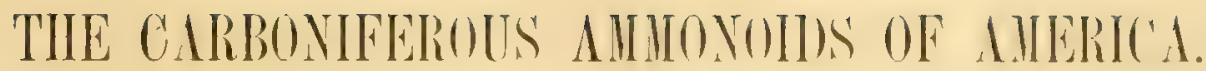

\author{
By James l'errix Simiti. \\ STRA'TIRAPII OF 'TIF AMEIRICAN CARIBONIFEROUS. \\ LOWER CARBONIFEROUS.
}

Kinderhook.-The oldest Carboniferous fuma of America is typically developed in the northern part of the Mississippi Valley, where the formations in which it is found have been called Kinderhook, Chontean, Marshall, and Waverly. Ammonoids of this epoch are best known from the goniatite beds of Rockford, Ind., where the following species have been found: Prolecanites lyoni Meek and Worthen, Agunides rotutorius de Koninck, MIensteroceras oweni Hall, M. parallelum Hall, Prodromites gorbyi Miller, I. promaturus Smith and Weller. In addition to these, the Kinderhook stage of other parts of the State has furnished Prolecunites yremii Miller and ITuensterocerus indionense Miller. 'The Chontean limestone near Sedalia and Louisiana, Mo., has also furnished a number of anmonoids: Prolecanites louisianensis Rowley, I'. gurleyi Smith, Aganides jessiea Miller and Gurley, A. discoidalis Smith, Prodromites gorbyi Hiller, P. omatus Smith, Pericyclus blairi Miller and Gurley, Muensteroceras? holmesi Swallow, M.? morganense Swallow, and M.? osagense Swallow.

The Marshall group of Michigan has furnished Prolecanites houghtoni Winchell, P. marshallensis Winchell, Muensteroceras oweni Hall, M. parallehm Hall, M. holmesi Swallow, P'rionoceras? andrewsi Winchell, Aganides? propinque Winchell, A. romingeri Winchell, A. shumardianus Winchell, Glyphioceras? pygmaeum Winchell.

'The Lower Waverly, or Kinderhook, of Ohio has furnished Prolecanites lyoni Heek and Worthen, P. marshallensis Winchell, Prionoceras? andrewsi Winchell, P.? ohioense Winchell, Aganides? shumardianus Winchell. 
The Kinderhook stage of Iowa has furnished Prodromites gorbyi IIiller, Agoniatites opimus White and Whitfield.

Cephalopor fiunas of the Toumaisian formation, the European equivalent of the Kinterhouk, are known at Tournai in Belgium, Erdbath in Germany, and in Ireland, where the most characteristic genera are Aganides,

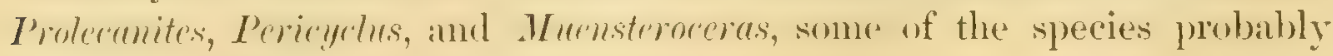
being identical with American forms.

Cephalopod faunas of 'Tournaisian age are not yet known elsewhere in the world.

Osage-While marine deposits of Osage or Burlington-Kenkuk age are widely distributed in America, ammonoids are cited from but two places-from the Burlington limestone of Louisiana, Mo. (Muensteroceress. osagense Swallow), and from the Lpper. Warerly formation of ()hio (Aganides? sciotoensis Miller and Faber).

St. Louis-Chester. - The St. Louis-Chester, or Ste. Genevieve, stage of Indiana and Kenturliy has fumisher the following species: Glyphou-

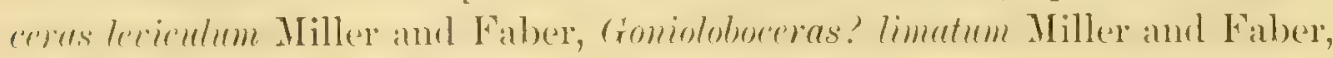
Goniatites kentuchiensis Miller, G. greencastlensis Miller and Gurley, G. subcircularis Miller:

The only goniatite found in Illinois in this formation is Nomismocerus? momroense Worthen.

The lower part of the St. Louis-Chester stage in Arkansas, the so-called Fayetteville shale, has yielded Bactrites carbonarius Smith,

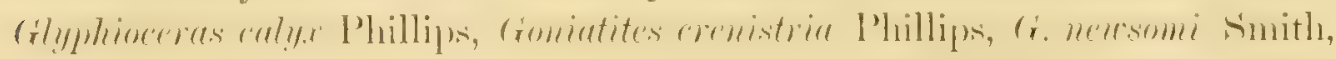
G. sphcericus Martin, G. striatus Sowerby, G. subcircularis Miller. The upper part of the St. Louis-Chester in Arkansas, the Boston group, has

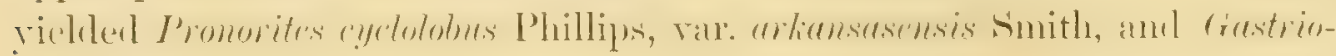
ceras bromeri Smith.

The Bend formation of Texas, which has been assigned by the writer

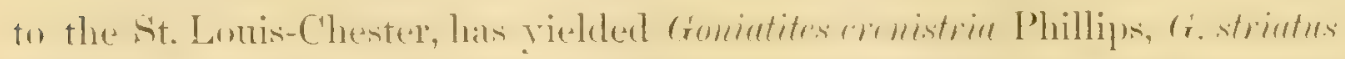

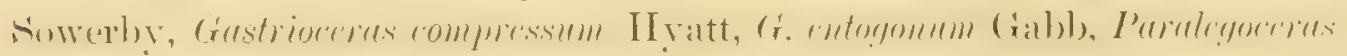
iowense Meek and Worthen, and P. texanm Shmmard.

Cephalopod famas of St. Louis-Chester age are known in the Visé formation of Europe at Visé in Belgium, at Bolland in Yorkshire; in the Culm of the Hartz Mountains; in the upper Kollenkalk of Silesia; and in the Carboniferous limestone of the Pyrenees in Spain. The most char- 


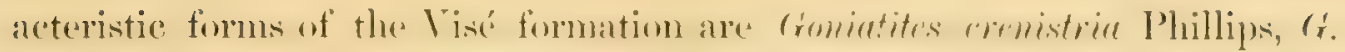

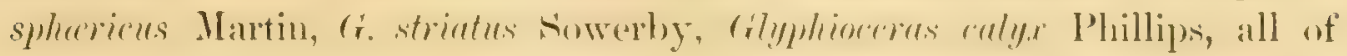
which occur in America in the same horizon.

\section{UPPER CARBONIFEROUS.}

Lower Coal Measures.-Goniatites are known certainly in America from the Lower Coal Measures at but a single locality, near Morrilltom, in Arkansas, where Paralegoceras newsomi Smith was found; this rarity of cephalopods from this horizon is due in part to the fact that the marine beds of the Lower Coal Measures have been deposited eliefly in the southwest, and that most of this time is represented in Missomi, Mllinois, Indianal, and adjacent States by an erosion interval.

Widdle Coul Mersures. - The Middle or Productive Coal Measures have furmished gomiatites in but few places. The following fossils have besen found in this formation: In Illinois, Prolecanites? compartus Meek and Worthen,

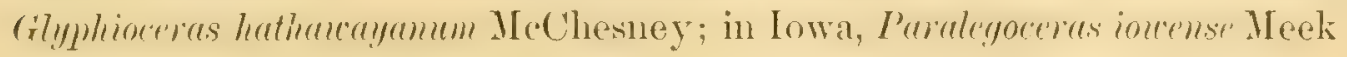

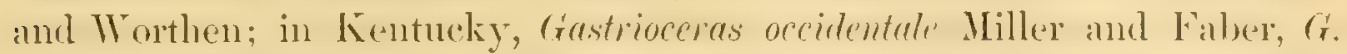
molinense Cox, Veoicoceres elthornense Milles and Cxurley, Gomiatites lunatus Miller and Gurley; in Arkansas, Gustrioceres exelsum Meek, Gr. glolulusum Meek and Worthen, Cr. corlonarium Buch, Cr. listeri Martin, Imomorites siden-

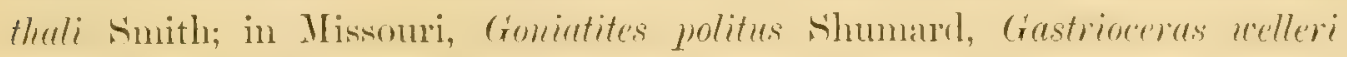
Smith; in Texas, Popanoceras parkeri Heilprin.

This formation has commonly been called Lower Coal Measures in the States within the Mississipun Valley, hut it does not form the luotem of the series, and in Arkansas is separated from the limestones of the Mississippian by several thousand feet of shales and sandstones-the so-called Arkansan formation.

This fauma is represented in the zome of Gastrioceras listeri in western Europe, especially in Silesia, Belgium, and England.

Upper Coal Measures. - The Upper Coal Measures have furnished the

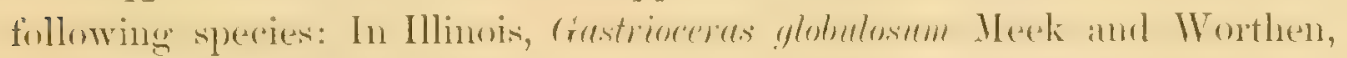
G. montgomeryense Miller and Gurley, G. illinoisense Miller and Gurley,

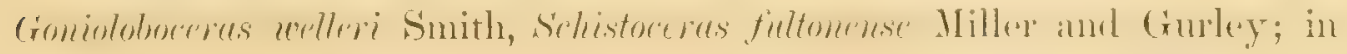
Ohio, Schistoceras hildrethi Morton, "Goniatites" colubrellus Morton; in Missouri, Milleroceras parrishi Miller and Gurley, Gastrioceras excelsum Meek, G. kansasense Miller and Gurley, G. planorbiforme sliumard, G. 
subcrum Hiller and Gurley, Schistocens missoniense Miller and Faber; in Kansas, "Goniatites" parvus Shumard; in Texas, Gonioloboceras velleri

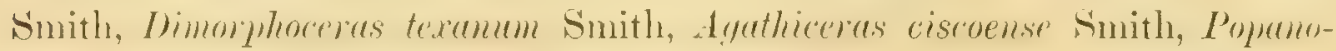

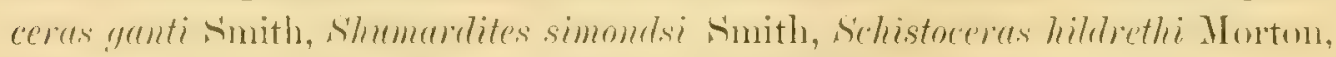
S. Jiyatti Smith, Gastrioceras globulosum Meek and Worthen, G. subcaum

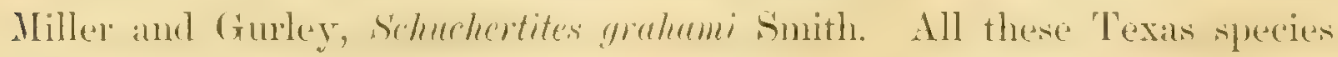
came from Graham, in the Cisco formation, associaterl with a typical Upper Coal Measures famna. Many of the other species are identical with forms in the Uralian formation, but the numerous ammonites are more highly developed than any known in the Eumpan Iprere ('onl Measures: the matiloids found in the Graham beds are mostly identical with forms that also occur in the overlying Wichita. Permian, as are also most of the other invertebrates. But the stratigraphic position is about 1,000 feet below the Wichita beds, in a region where the structure is exceedingly simple, the strata boing nearly horizontal, thus precluding the possibility of a mistake in the stratigrapliy.

Permian.-Ammonoids are at present known in the American Permian only in 'Texas, in Wichita, Baylor, Archer, and Kent counties. 'The geological survey of 'Texas recognized two divisions of this group: (1) The Wichita and Clear Fork beds, from which Dr. C. A. White ${ }^{a}$ described the following forms: Paralegoceras baylorense White, Popanoceras walcotti White, Waagenoceras cumminsi White, Medlicottia copei White; (2) the Double Mountain beds, from which only a single ammonite is known, Waagenoceras hilli Smith, described in this paper.

The Wichita beds are generally correlated with the Artinsk stage of liussia, the Fusulina limestone of Sosio in Sicily, and the Midrlle Productus limestone of India, some of the ammonite species being very nearly related in all these localities.

The Double Hountain beds are probably Upper Permian, and shomld be correlated with the Hungarites beds of Djulfa in Armenia and the Upuer Productus limesteme of India; but this is purely stratigraplice, the known fanma of the Upper Permian of 'Texas being too scanty to warrant paleontologic correlation. 
STRATIGRAPHY OF AMERICAN CARBONIFEROUS.

Correlution tuble of the Cremoniferous.

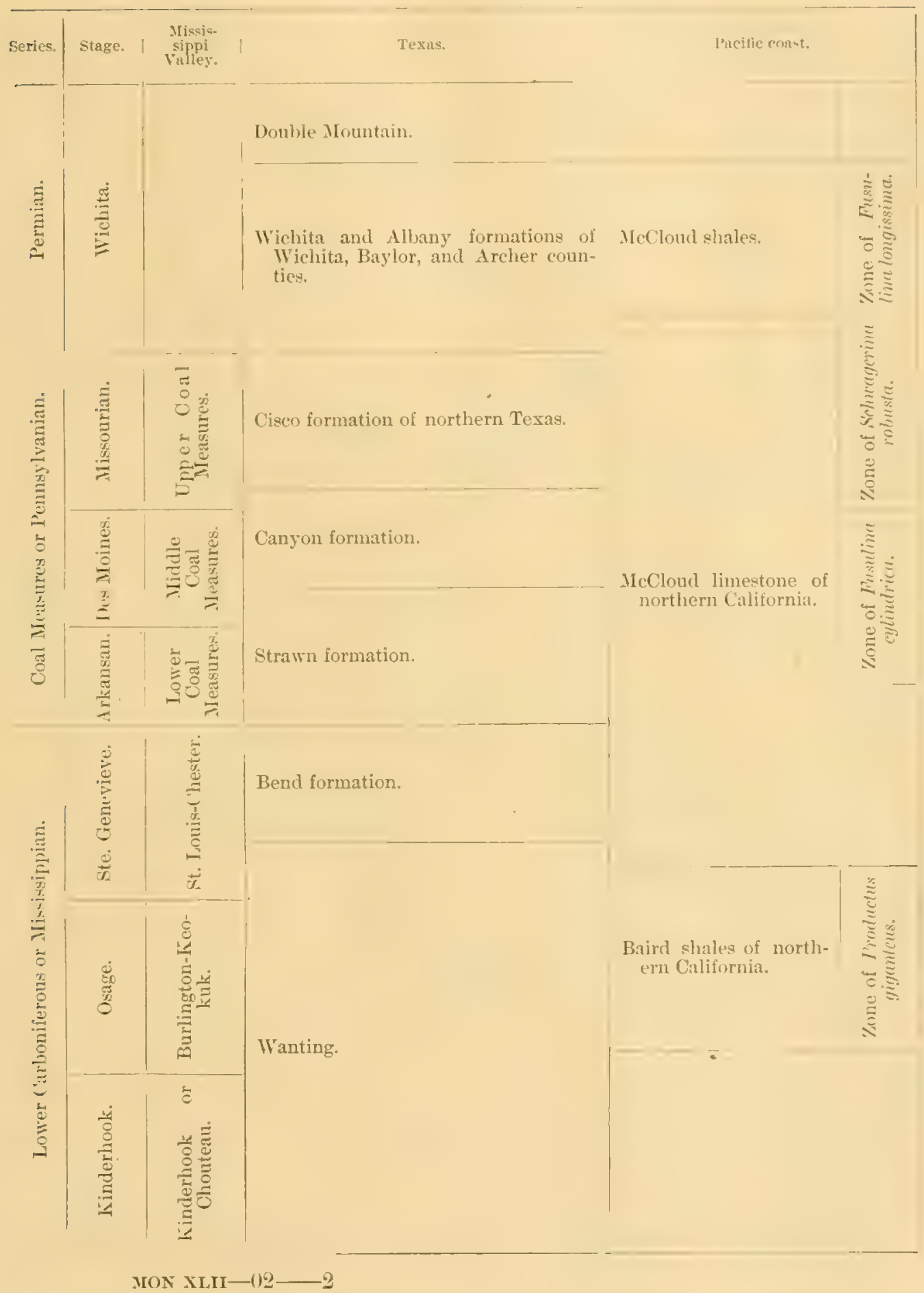


Complation tuble of the Carboniferons-Continued.

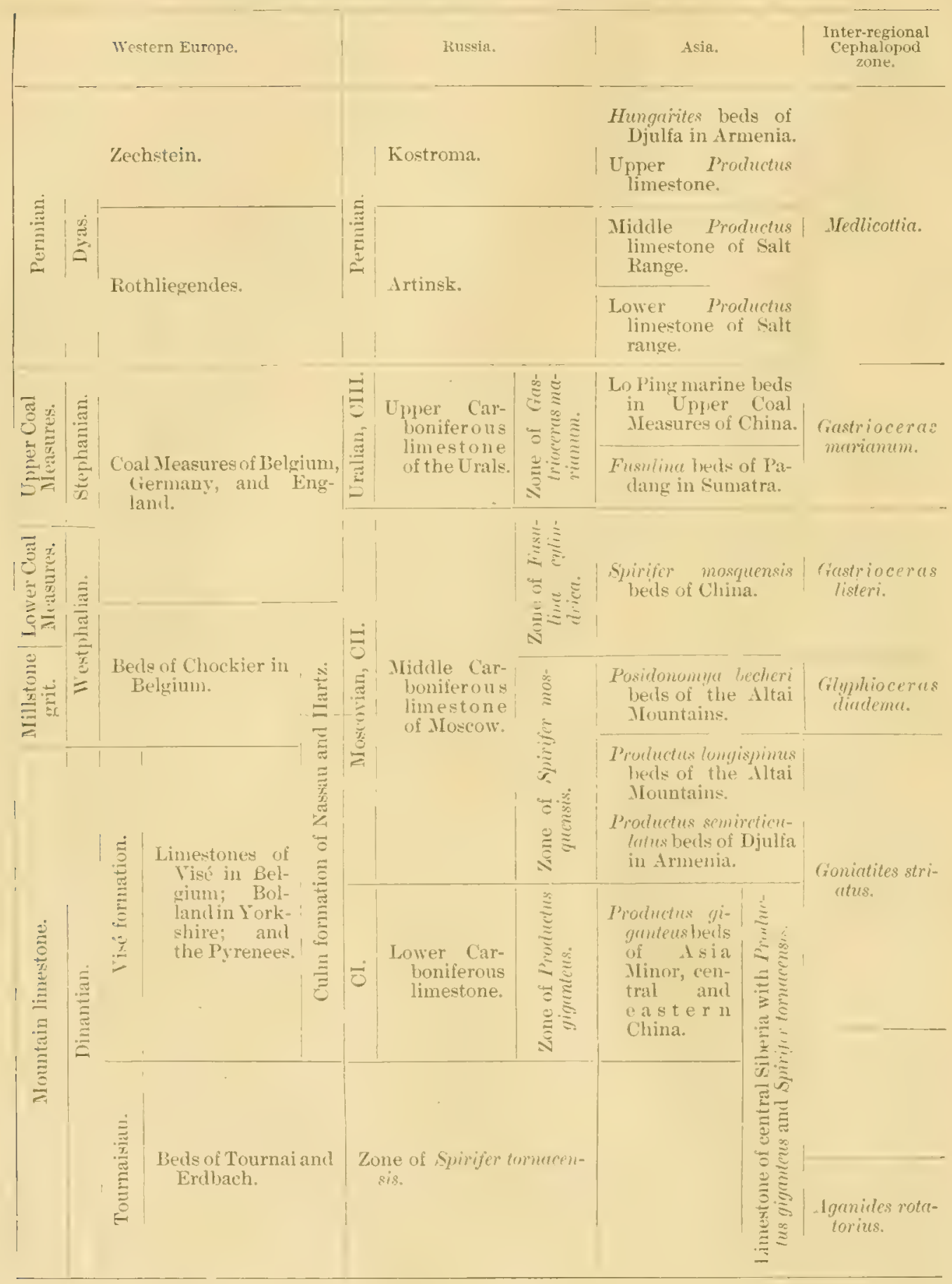




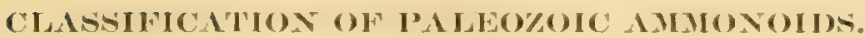

Formerly all Paleozoic ammonoids were classified as Goniatites, with the exception of Clymenia, which was at first supposed to be a nautiloid. As more forms became known, the unwieldiness of the genus Goniutites was

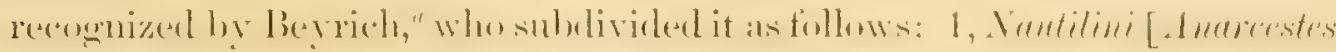
and Mimoceras]; 2, Simplices [Tomoceras, Aganides, and P'rionoceras]; 3, Aequales [Sparadoceras and P'rolecanites]; 4, Irregulares [Beloceras]; 5, Primordiales [Geplayroceras]; 6, Carbonarii [Glyphioceras, Goniatites s. str., and Gastrioceras].

Afterwards another classification was attempted by G. and F. Sandberger ${ }^{b}$ who established the following subdivisions: 1, Linguati [Sandbergerocerus $] ; 2$, Lanceolati $=$ [Aequales p. p. Beyrich $] ; 3$, Genufiacti $=[$ Carbonarii Beyrich]; 4, Servati $=[$ Irregulares Beyrich $] ; 5, \quad$ Crenati $=[$ I'rimordiales Beyrich]; 6, Acutolaterales [MLaneceras]; 7, Magnosellares $=$ [Simplices Beyrich $] ; 8$, Nautilini $=[$ Noutilini Beyrich $]$.

The divisions of Beyrich and those of the Sandbergers were not intender to represent genera, and they mostly contain heterogeneous elements. At that time even the old genus Ammonites, comprising sereral. times as many species as Goniatites and species much more various in form, was still considered a unit.

Goniatites was supposed to differ fundamentally from dmmonites, although it was known to L. von Buch and Quenstedt that the ammonites in their youth went through a goniatite stage of growth; but since these forms were all supposed to be special creations, this phenomenon was not comnected with the idea of evolution, and had no effect on classification.

The first attempt to distinguish genera among the goniatites was made by Dr. E. von Mojsisovics" in 1882, who named Anarcestes, P'inacites, Promorites, Prolecanites, and I'ericyches, bringing them into rather fanciful relationships to his genera of 'Triassic ammonites.

The first systematic attempt to group all goniatites in families and genera was by Hyatt in his Genera of Fossil Cephalopods, where they were classified as follows:" Family 1, Nautilinidre, including Himoceres Hyatt,

"Beitr. z Kennt. Rhein. Ueberwangsgeb.

cephalop. Jeeliterranen Triasprovinz.

W Verstein. Rheinischen Schichtensystems in Nassau.

"Proc. Boston Soc. Sat. Hist., Vol. XYII. 
Anarestes MIojsisovies, Agoniatites Mfeek, Pinacites Mojsisovies, Celceceras

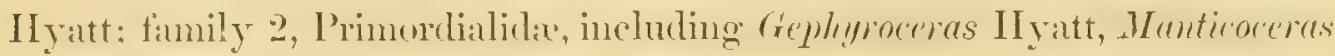

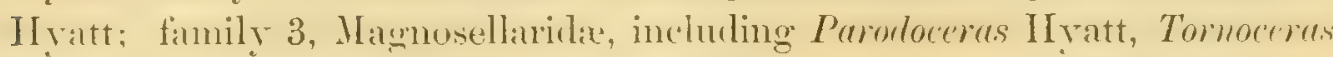

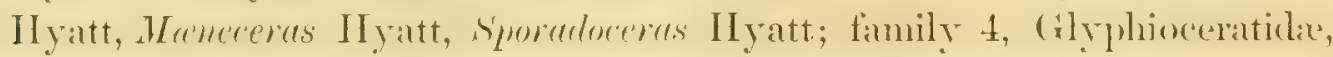

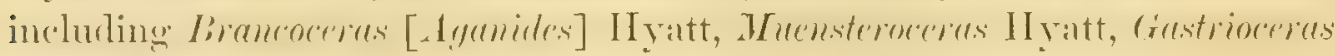

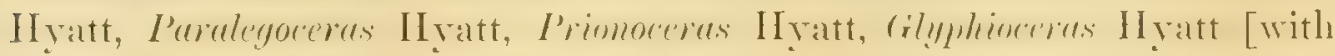

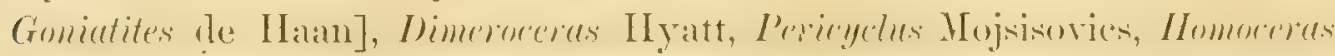

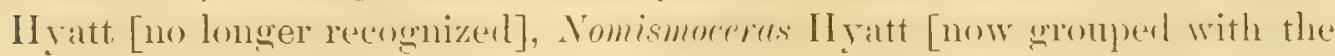

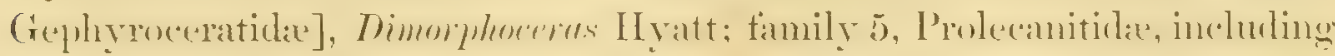
Sandbergeroceras Hyatt, Beloceras Hyatt, Prolecanites Mojsisovics, P'harci-

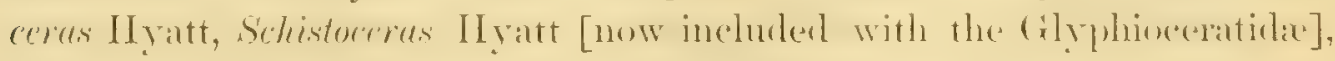
Trienoceras Hyatt, Pronorites Mojsisovies, Popanoceras Hyatt.

Medlicottia Waagen, Suyeceras Mojsisovies, and Lobites Mojsisovies were

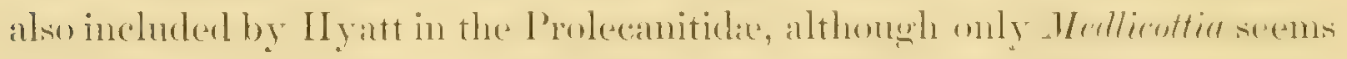
to show any relationship to Prolecanites, and that only remotely.

Hyatt's families do not represent genetic series, but are polyphyletic

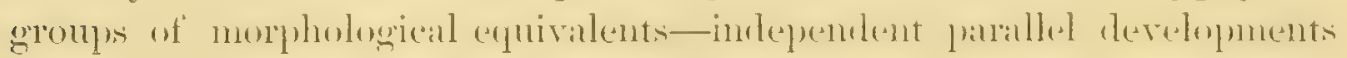
from kindred stocks.

Before this publication of Hyatt, genera of Paleozoic ammonoids had already been recognized by Waagen". in the Permian of India and Russia

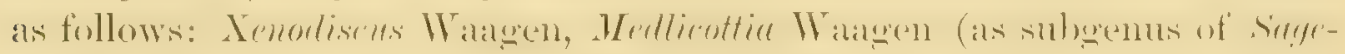
ceras Mojsisovics), Cyclolobus Tragen. These were classed with the ammonites on account of their resemblance to 'Triassic generia.

Gemmellaro's monograph on the Permian cephalopod famma of Sicily revealed hitherto unsuspected riches in Paleozoic ammonites of the fami-

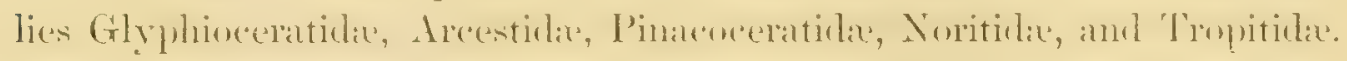

A somewhat similar fauna was described by Dr. C. A. White ${ }^{c}$ from the Permian of Texas, with Paralegoceras, Popanoceras, Waagenoceras, and Medlicottia.

The classic Permian fauna of the Ural Mountains was redescribed and revised by Karpinsky, "who showed the gradual transition from the Carboniferous soniatites into the Pernian ammonites in the Glyplingeratidax, Arcestidx, and Prolecanitidx.

a Pal. Indica, Ser. XIII, Salt Range Fossils, Vol. I.

b Fauna calc. Fusulina.

$c$ Bull. U. S. Geol. Survey No. 77.

a Die Ammoneen der Artingk-Stufe. 


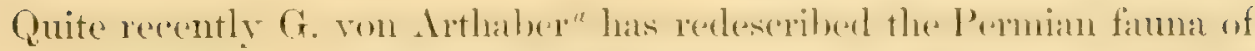
Djulfa in Armenia, making known the presence in the same beds of

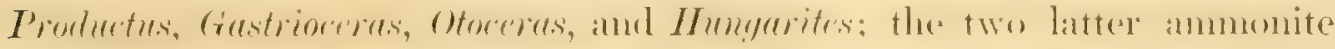
genera are known elsewhere only in the Trias, and the beds containing them are considered as uppermost P'ermian, later even than the Upper Productus limestone of the Salt Range.

When these new discoveries began to be known, it became evident that a new classification of the Paleozoic ammonoids was necessary, since there was no place in the old scheme for the new forms. 'The first attempt to give a phylogentete classification of ammonoids, showing the relationship of the goniatites and the ammonites wats made by steimmamn," but this was largely speeculative, not hased on the ontogeny of any species, and hence fails to express the true relationships of the groups.

The most satisfactory attempt at a phylogenetic classification of the Parleozoic ammonoids is that of E. Hang, in which all known senera are grouped in five phyla, or superfamilies: (I) Axarcestid E, including Anarcestes, Parodoceras, Prionoceras, Prolobites, MLeneceras, Sporadoceras, Dimeroceras, Pharciceras,? Sandbergeroceras,? Trianoceras; (II) Gryphio-

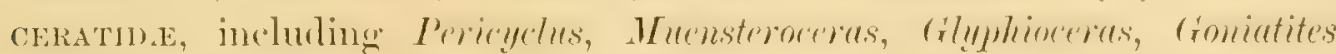
s. str., Gastrioccras, Paralegoceras, Agathiceras, Adrianites, Stacheoceras;

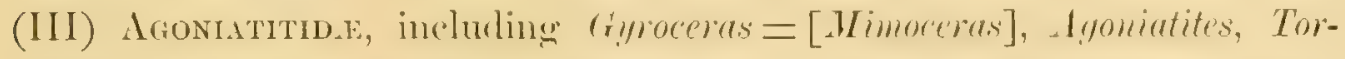
noceras, Pinacites, Aganides $=[$ Brancoceras Hyatt], ? Pronannites, Dimor-

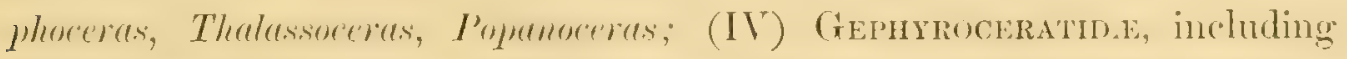

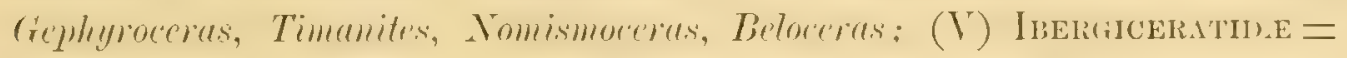

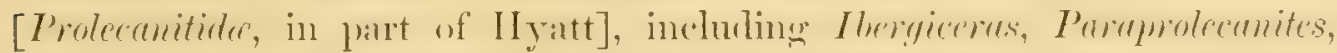

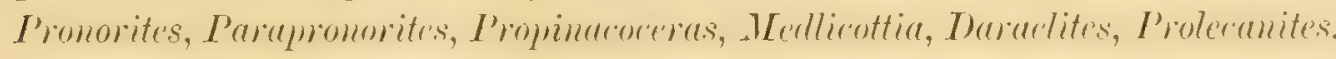

On Table II, page 113, of Haug's work, is an attempt to show graphically the relations of the Paleozoic ammonotes to each other and to their successors of the Mesozoic. This classification is a distinct improvement over that of Steinmann, but also makes the mistake of errouping together heterogeneous elements and separating forms that are manifestly of near kinship. It also seems to the writer that there are too

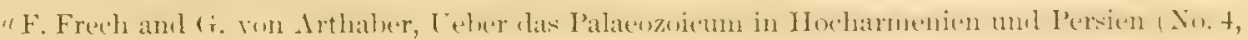
G. von Arthaber, Das Jüngere Palaeozoicum aus (er Araxes-Enge bei Djulfa): Beitr. Palaeont. und Geologie Oesterreich-Ungarns und des Orients, Vol. XII, No. IV, 1900.

$b$ Elemente der Palïiont.

$c$ F́tudes sur les Goniatites. 
few phyla recognized. Since most of the ammonoid genera of the Devonian and Carboniferous were progressive, and probably gave rise to descendants in the Permian and Mesozoic, there ought to be nearly as many phyla, or genetic series, as there are primitive genera. But since some of these are nearer of kin than others, for the sake of convenience we group them together, in spite of the fact that this does not express the true filiation of the genera. Thus, even at the best, many of the so-called fimilies will not be a true genetic series, but a group of nearly related morphological

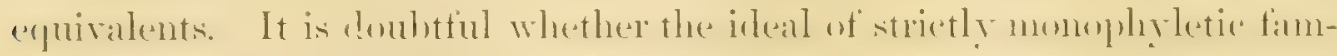
ilies and genera can ever be realized, even if the geologic record should turn out to be less broken than we now suppose it to be. Of the great majority of Paleozoic ammonoids we do not now know, and probably shall never know, the ontogeny, and until we are able to compare in erery case the individual ontongens with the supposed genetic suceesion as preserved in the rocks we can never hope to establish a classification that will not be overthrown by each discovery of new faunas.

One great difficulty in classification is that we do not yet know what characters are of fundamental importance in taxonomy. One systematist selects the length of the body chamber as the criterion, another the septa, anther the sculpture. A rigid adherence to any one of these systems leads to absurdities, for it becomes clear that any one of these characters may appear at different times in different stocks; and a dependence on any one character would cause the grouping together of forms that have no real kinship. The only safe way is to take into consideration all these characters, where it is possible, and to compare in every case the individual ontogeny

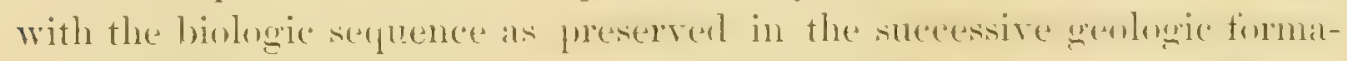
tions. The writer has endeavored to do this in the classification adopted in this work.

TABLE OF PALEOZOIC AMMONOID GENERA.

For convenience of reference there is given below a table showing the genera and families now known from the Paleozoic, and their geologic range. This is based on the works of Hyatt, Gemmellaro, Karpinsky, Frech, Waagen, von Mojsisovics, ron Arthaber, Hang, and Diener, and on the writer's own studies in the ammonoids of the Carboniferous and Lower Trias. This classification is only tentative; it represents merely the present state of linowledge, or rather of opinion, concerning the deri- 


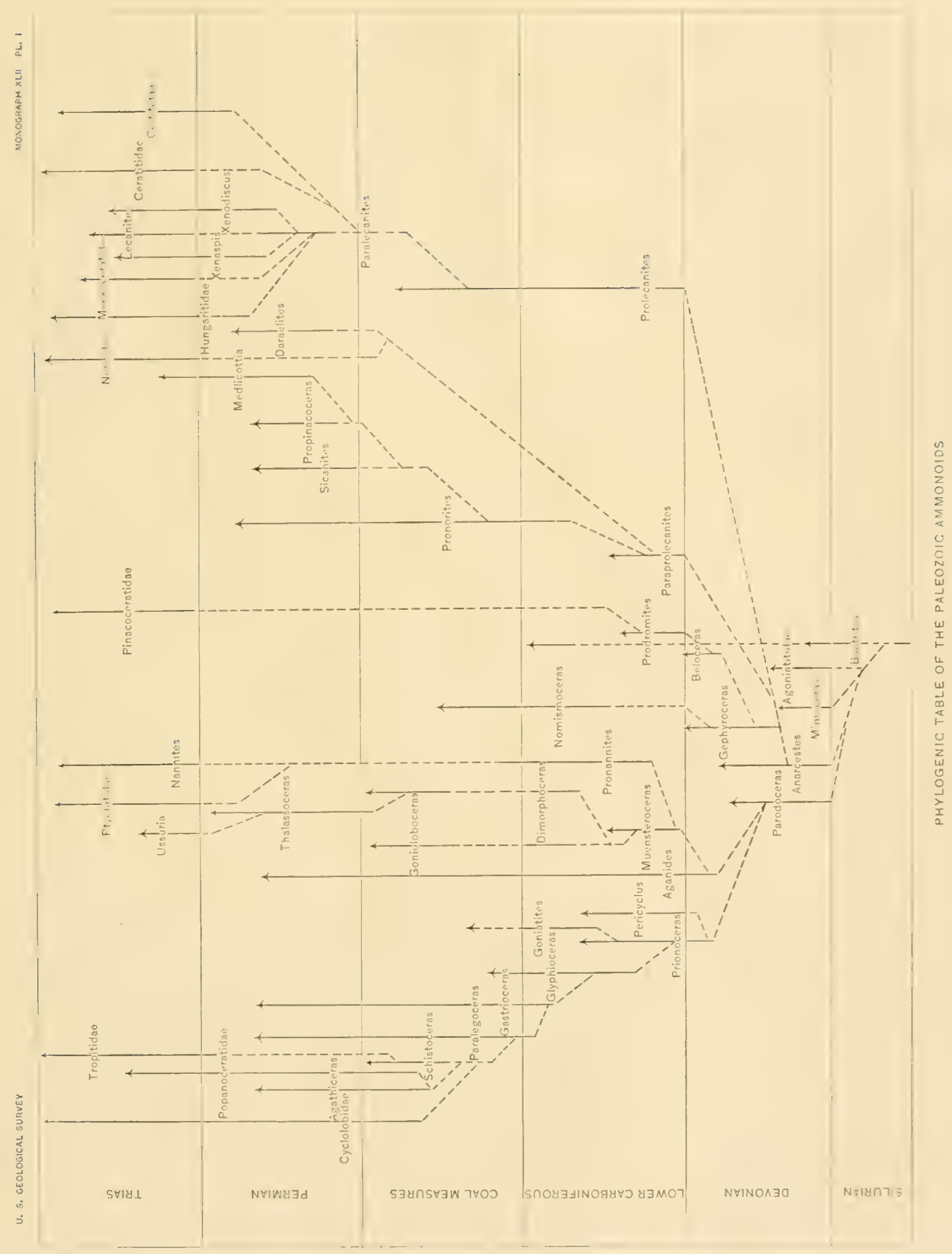



vation and relationship of the various groups. It is subject to revision or modification by any new discovery of forms, or any studies in the ontogeny of groups of which the ontogeny is at present unknown. It is not rlamed that it is an alsolute phylugente classifieations: it is merely an attempt at such a classification. The writer has followed strictly the classifications of other investigators where he had no new observations of his own to offer; he has departed from the accepted classification in

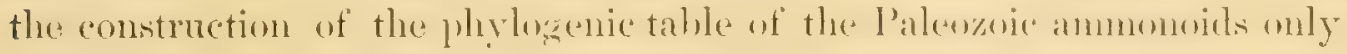
where ontogenie stuly of the valious groups makes such chlanges nerestiary.

Table of Paleozoic ammonoid genera.

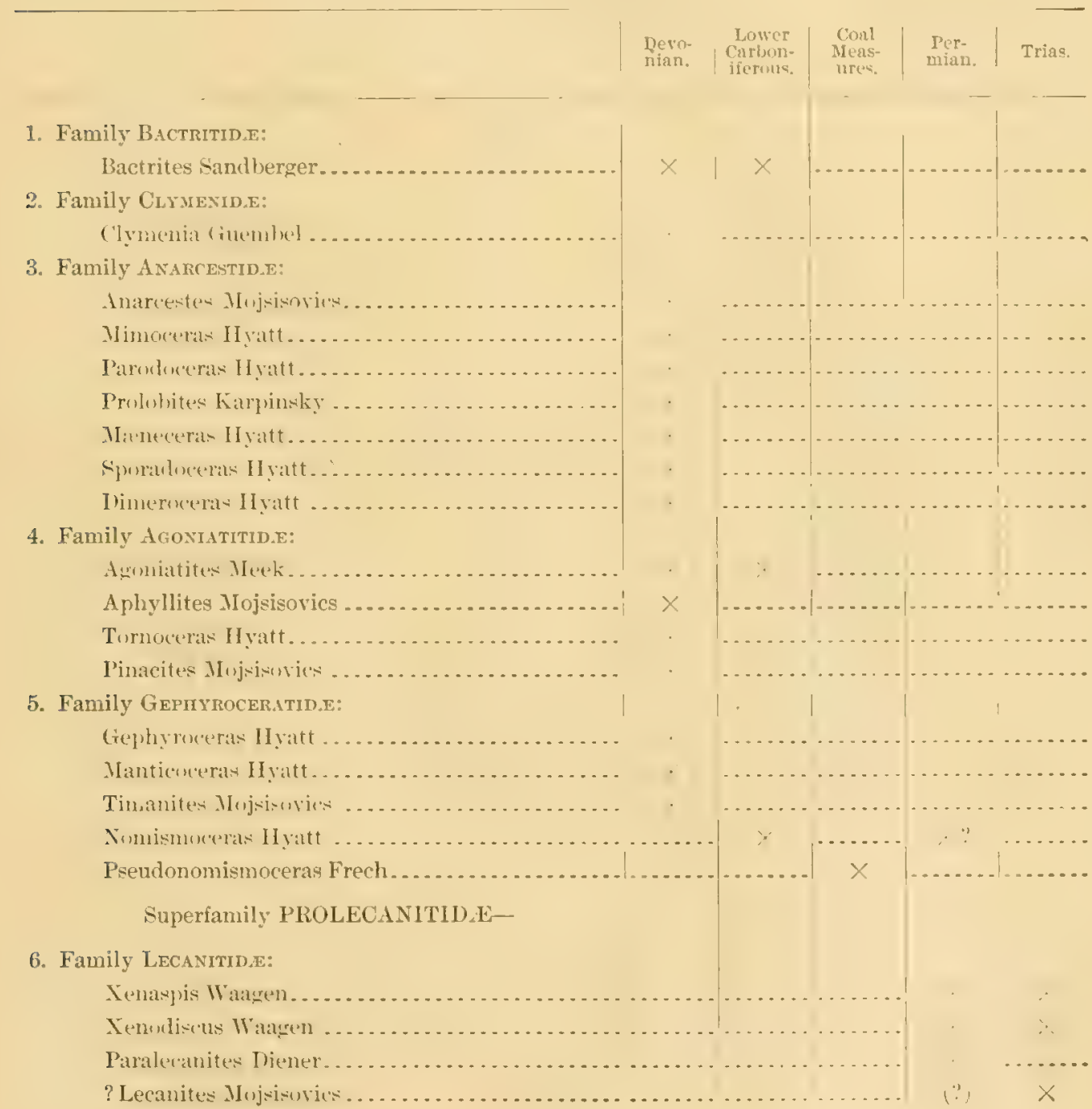


Table of Palenzoic ammonoid gener - Continued.

Superfamily PROLECAXITIDA-Continued.

7. Family Beloceratide:

Probeloceras Clarke

Lielucerat Hyatt

Prodromites Smith and Weller

8. Family Provoritide:

Promoritess Mojusisuvic:

Paraprolecanites Karpinsky

Sicanites Gemmellaro

Propinacoceras Gemmellaro.

Medlicottia Waagen

9. Frmily Noritide:

Darelites Gemmellaro

s.huchertites smith

10. Family Prolecanitid.e:

Prolecanites Mojsisovics

? Paraceltites Gemmellaro

?Sandbergeroceras 1 yatt

? Triatuseras II yatt .

? Pseuclarietites Frech

"I'henaleoceras Frenth

Phameicerats If yatt

11. Family HuxG.ARITIDE:

Hungarites Mojsisovics.

Otoceras Griesbach

Superfamily GLYPHIOCERATIDAE-

12. Family GLYPHoceratides. str.:

Prionumerats II yatt .

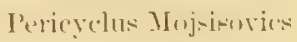

Glyphioceras Hyatt

(imiatites de Haan

Gastrioceras Hyatt

I'aralemen'eras Hyatt

sinistuceras Hyatt.

13. Family AGaNidide:

Aganicles de Montfort

Inensternems I1 yatt.

? P’onamnites Hany.

f imouloluкеrats IIyatt .

Jinomphoweras IIyatt

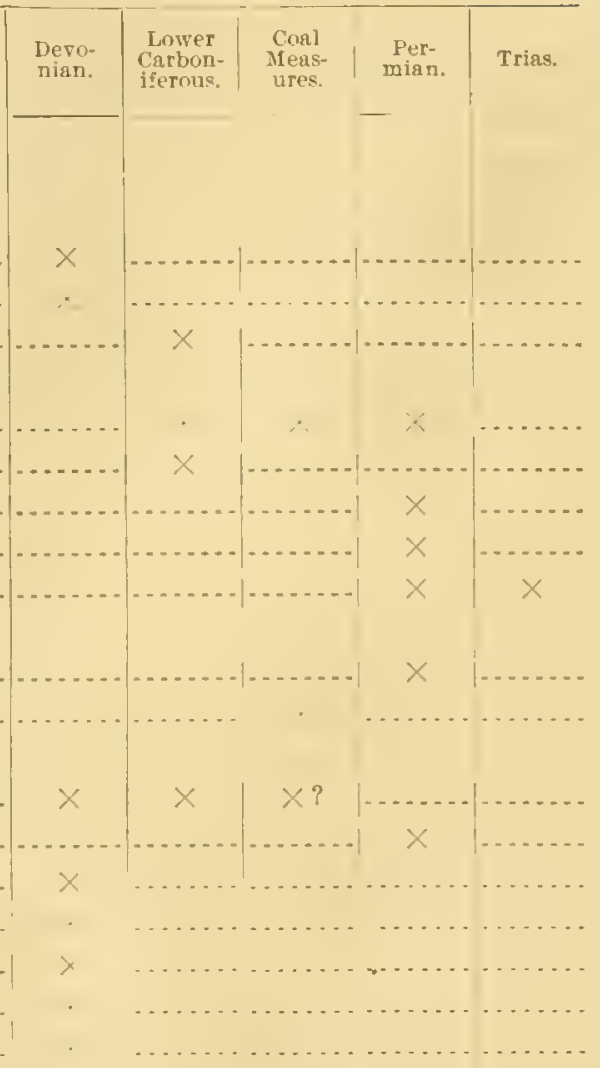


Table "f I'alcoznic ammonoid genera-Continued.

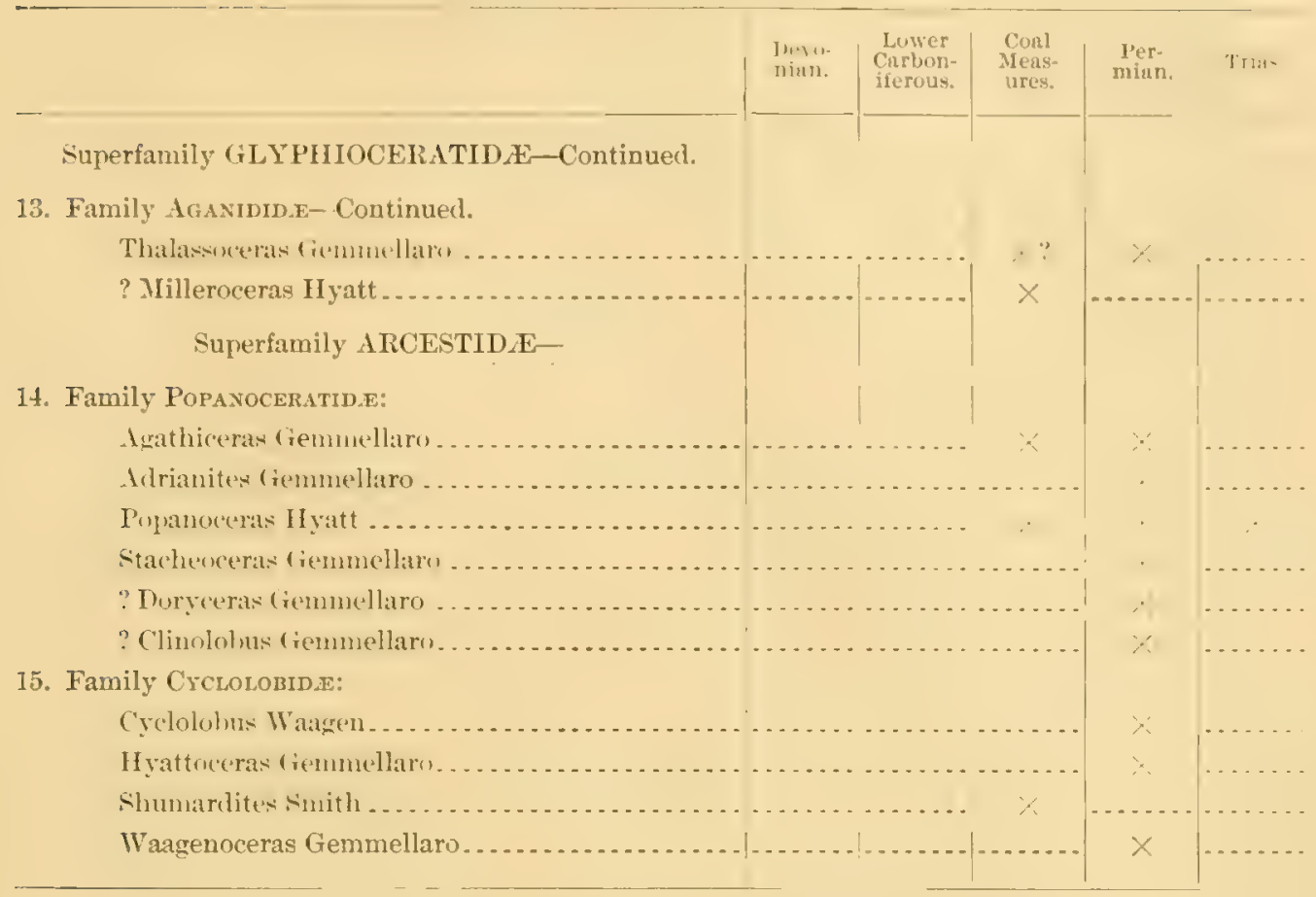

AMMONOIDS OF 'THE MMERICAN CARHONIFEIROUS. GENERA REPRESENTED.

The writer has made no distinction betreen goniatites and ammonites, because there is none that will hold. Certain families, or genetic series, contain some genera that, on account of simplicity of the septa, would be ealled goniatites, and others that might appropriately be termed ammonites. 'There are other forms that, while having simple or goniatitic septa, have forward-pointing siphonal collars and would thes fall wnder the detinition of ammonites. The form of the aperture has been frequently used as a mark of distinction between these two groups, but this is so commonly unkuown as to have little value in systematic work.

There are at present known in the American Carboniferous eleven farnilies, twenty-four genera, and eighty-nine species of ammonoids, besides two apocryphal species (not ammonoids). Their stratigraphice occurrence is as follows:

Kindermook: Prolecanites, Prodromites, Aganides, Prionoceras:, Mruensteroceras, Gonioloboceras?, Pericyclus, Agoniatites.

Osige: Aganides?, .Muensterocerus?. 
St. Lous-CHester: Goniolohoceras, Glyphioceras, Goniatites s. str., Gastrioreras, Paraleguceras, Pronorites, Nomismoceras?.

Lower Coat Measures: Glyphioceres, Gastriaceras, I'umlegoceras.

Midde Coal Measures: Popanoceras, Neoicoceras, I'olecanites?, Glyphiocerus, roniatites s: str., Gastrioceras, Paralegocerts.

Upper Cos Measures: Milleroceras, Glyphioceras?, Gastrioceras, Schistuceras, Shumardiles, I'umlegoceras, Lyathiceras, Popanoceras, Schuchertites, Goniblobocenas, Dimorphoceras.

Penman: Paralegocerrs, Popanoceras, II aagenoceras, Medlicuttia.

The association and range of the genera of the Upper Coal Measures are approximately the same as in the Uralian of Europe, except that in Furope the true ammonites are not known below the Permian.

Popanoceras, Shumardites, and Schuchertites would be classed by anyone among the ammonites, on account of their complex septa, while Schistoceras might justly be placed under the same group, on account of the large number of lobes and the forward-pointing siphonal collars.

While nearly all the characteristic European genera are present, some are extremely rare, represented by a single species, as Agathiceras, Dimorphoceras, Nomismoceras, and Pericyclus; others have a different range in America from that in Europe. Dimorphoceres appears first in Europe in the Visé horizon, but in America is unknown until the Upper Coal Measures, or Uralian. Popanoceras is known in Europe only in the Permian, but in America it occurs in the Middle and Upper Coal Mensures. Gastrioceras and Paralegoceras do not appear in Europe before the middle of the Coal Measures, but in America they are known in the St. Louis-Chester. I'rodromites, Gonioloboceras, Schistoceras, Shumarclites, and Schuchertites are not yet known in the European region.

These differences of range and association give us hints as to the region where some of these forms originated, but the information is too inclefinite to allow any positive statements as to the famal geengaphy of that time. This much is certain: At least periodically there was easy intermigration between the American and the European waters, for the community of genera, and even of species, is too great to be explained by any other hypothesis. 


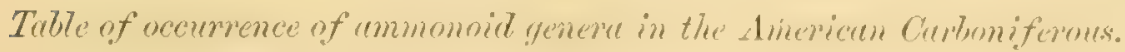

[The genera marked $\times x \times$ are common; thowe markel $x \times$ are rare; thome murkel $\times$ : arc very rare,]

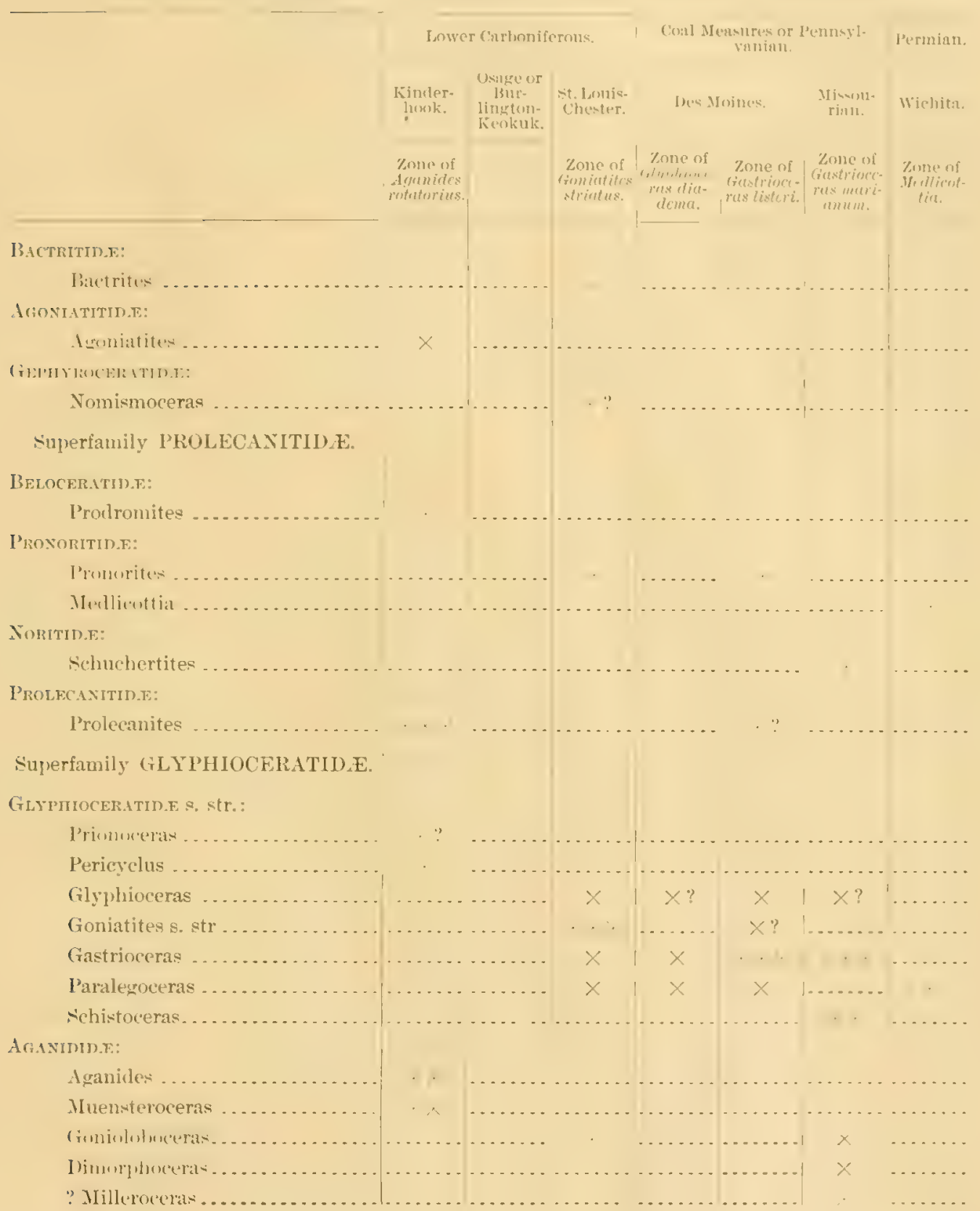


Table of occurrence of ammonoid genera in the American Curbonifersus-Continued.

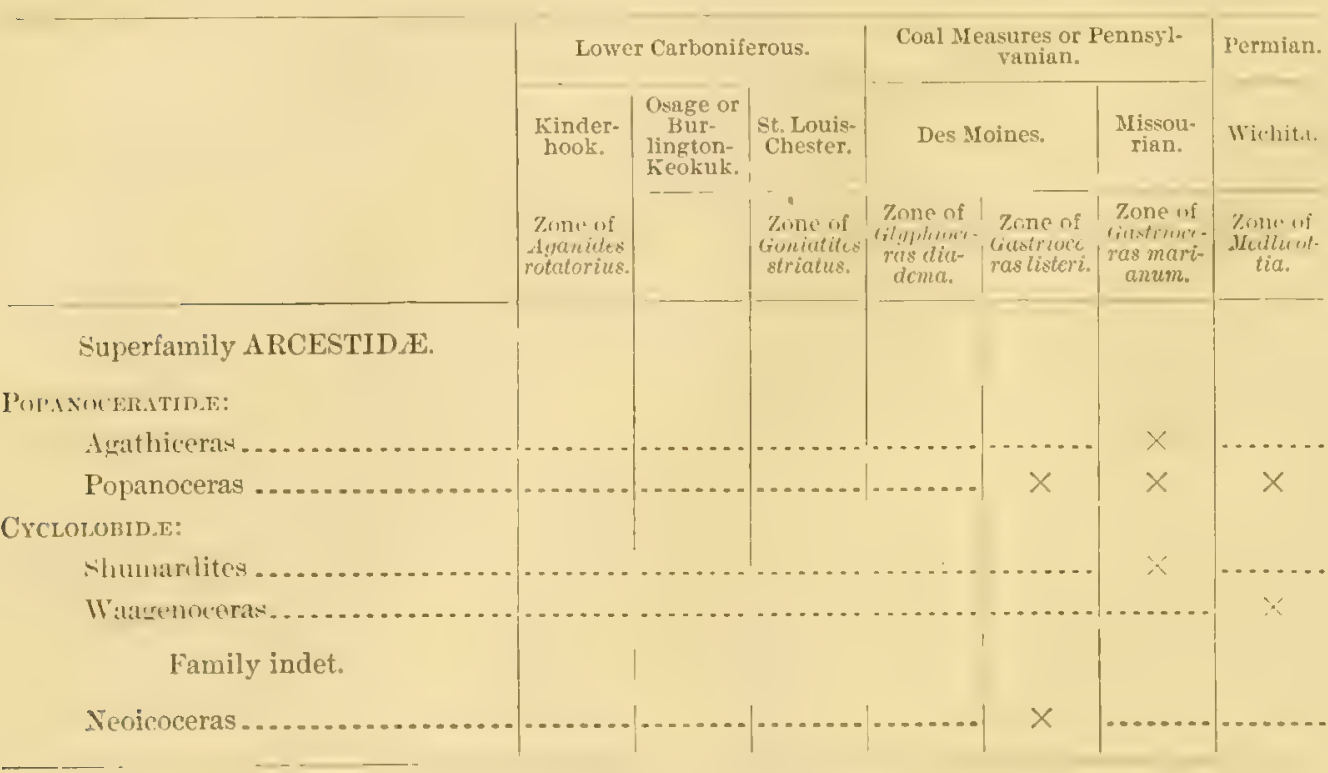

TABLE OF SPECIES DESCRIBED.

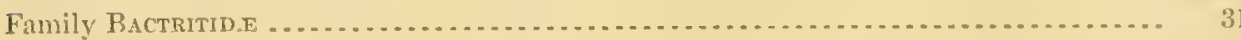

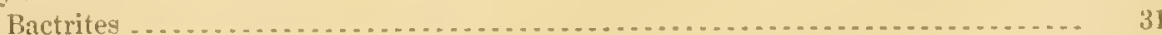

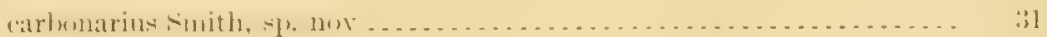

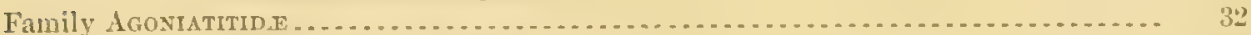

Agoniatites .... . . .

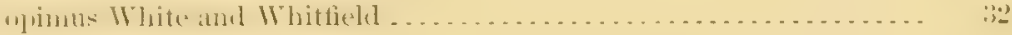

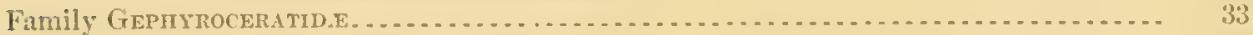

Vunismueras.

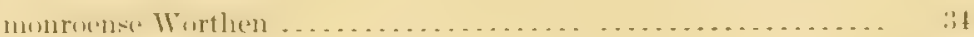

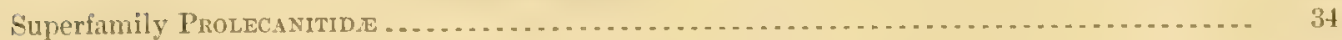

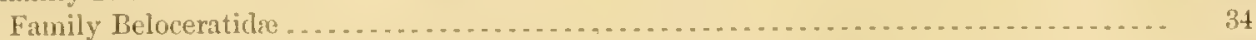

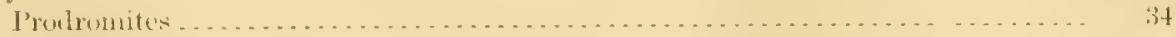

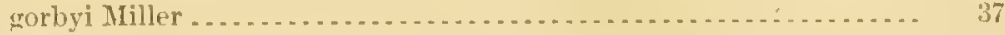

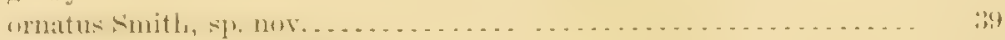

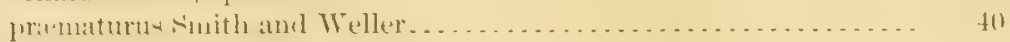

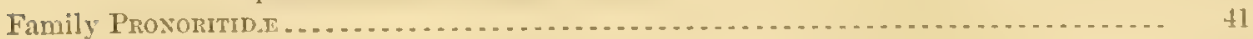

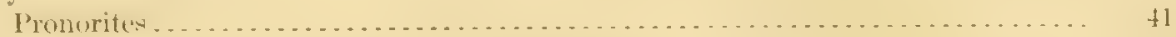

cyclolobus Phillips var. arkansasensis .................... 43

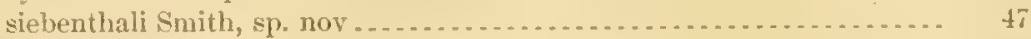

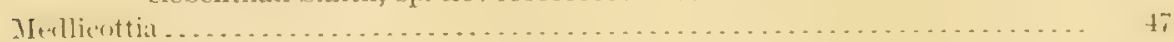

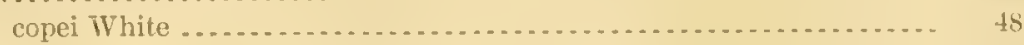

Family Nortтd . . . . . . .

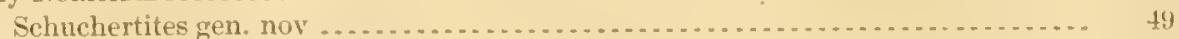

grahami Smith, sp. nov .................................. 50

Family ProLecanimid.E s. str...

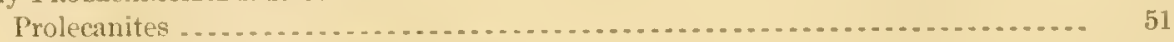

? compactus Meek and Worthen.....................

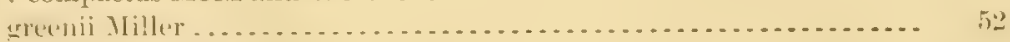

gurleyi Smith, sp. nov ..................................... 53 
Superfamily Prolecanitine-Continued.

I'age.

Family Prolecaxitum s. str-Continued.

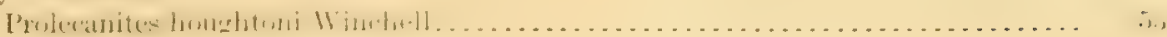

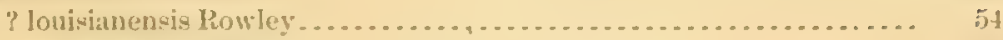

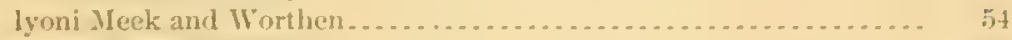

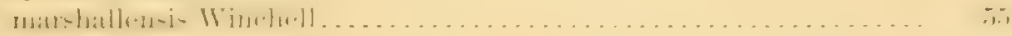

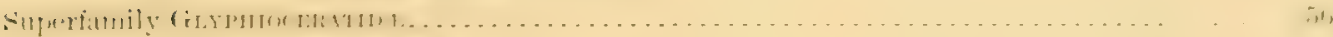

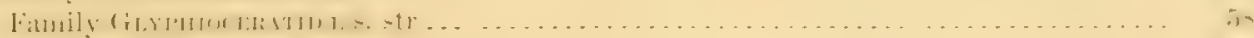

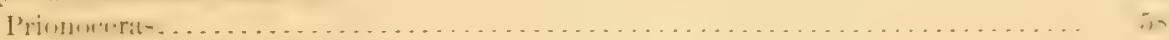

andrewsi Winchell .........................................

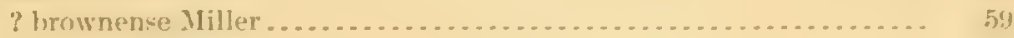

? vhinense Winchell .................................... 5 .

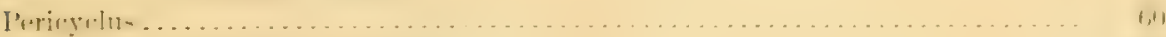

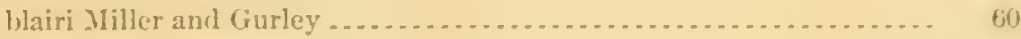

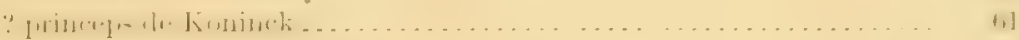

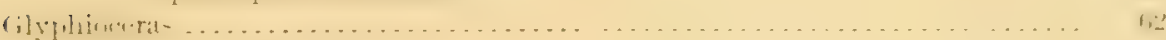

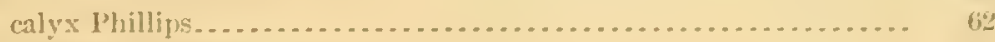

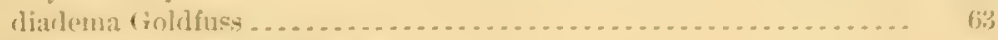

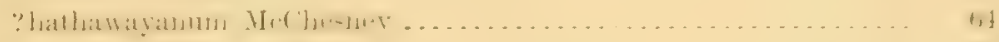

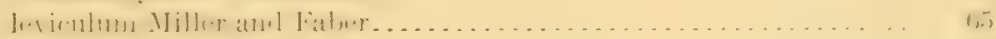

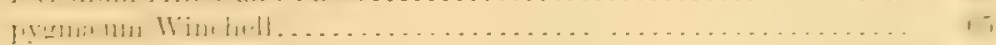

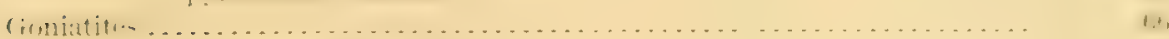

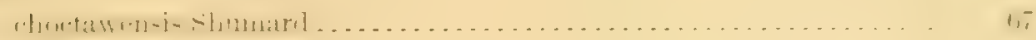

crenistria Phillips ....................................... fis

greencastlensis Jiller and Gurley.......................... ti;

kentuckiensis Jiller ..............................

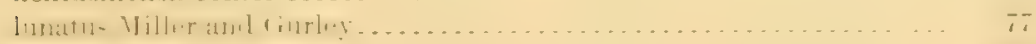

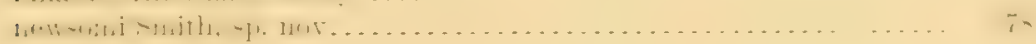

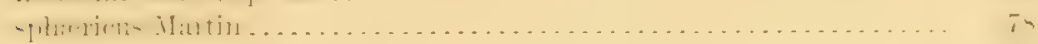

striatus sowerloy........................................

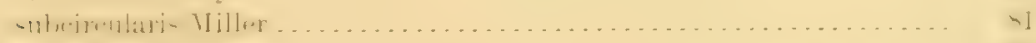

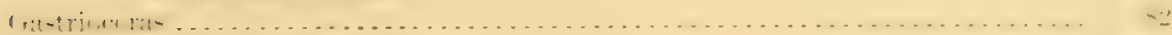

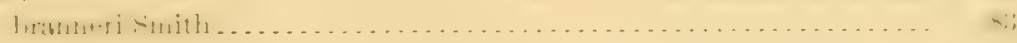

? carlonarium von Buch . . . . . . . . . . . . . .

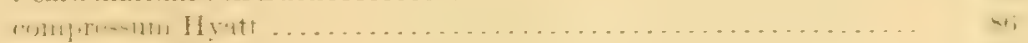

entogonum (jab) .....................................

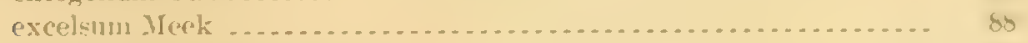

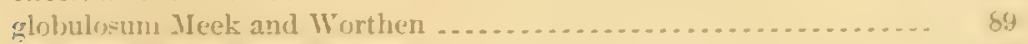

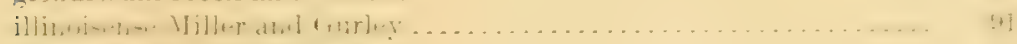

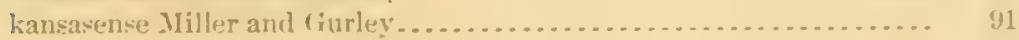

kn1,

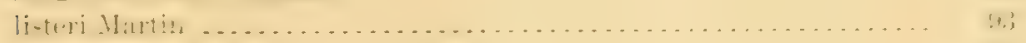

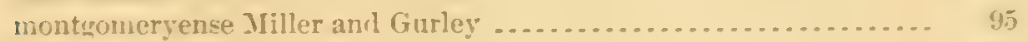

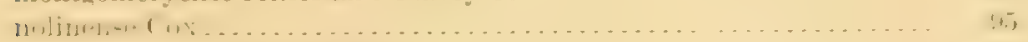

occirlentale Viller and Faber............................

- planorbiforme Shumart................................. 97

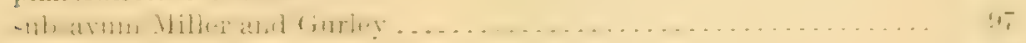

welleri Smith, sp. nov....................................

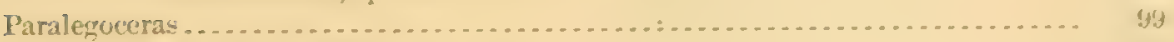

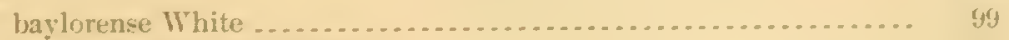

iowense Ileek and Wrorthen.............................. 100

newsomi Smith, sp. nov............................... 101

texanum Shumaril ........................................ 10 t

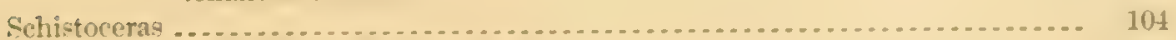

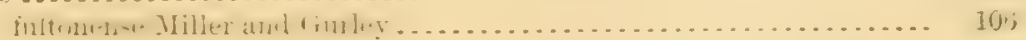


Superfamily GLyPRIOCER.ITID.I-Continued. Page.

Family Gup PIIOCER.TTID.E s. str.-Continued.

Schistoceras hildrethi Horton. ................................... 107

hyatti Smith, sp. nov ................................. 10 s $^{2}$

miscouriense Miller and Faber ........................... 111

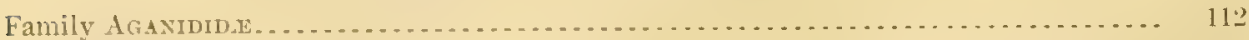

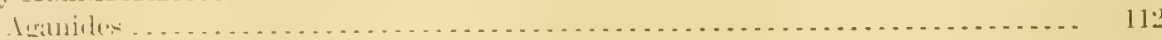

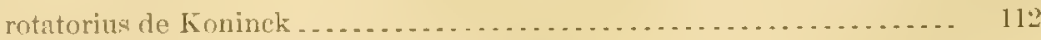

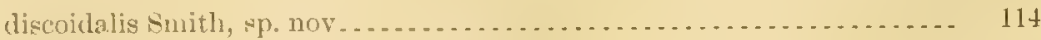

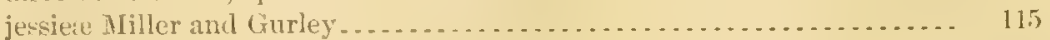

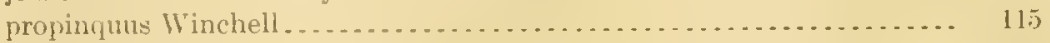

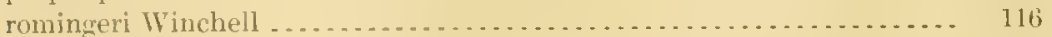

? sciotoensis Jiller and Faber. . . . . . . . . . . . . . . . . . . . . . 116

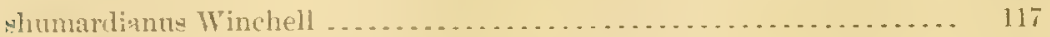

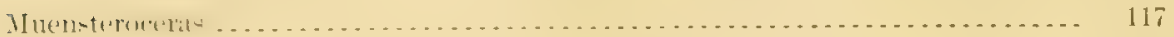

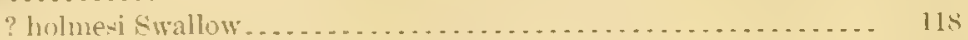

? indianence Miller.............................. 118

? morganence Swallow . . . . . . . . . . . . . . . . . . . . . . . 11 !

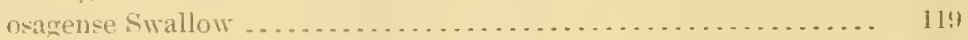

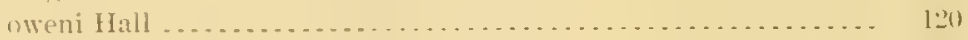

parallelum Hall . . . . . . . . . . . . . . . . . . . . . . . . . . .

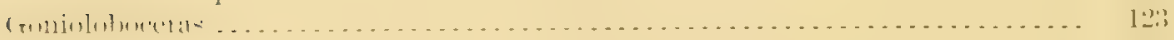

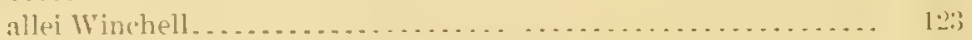

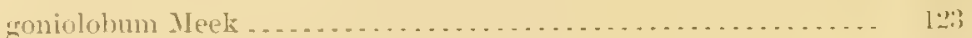

limatum Miller and Faber . . . . . . . . . . . . . . . . . . . . . . .

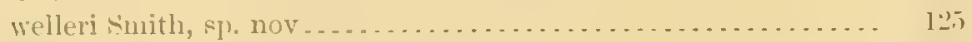

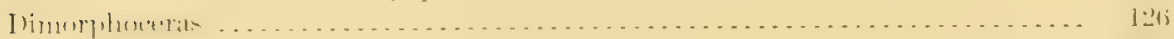

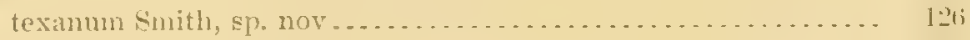

Milleruprit . . . . . . . . . . . . .

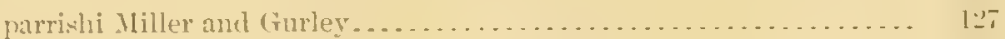

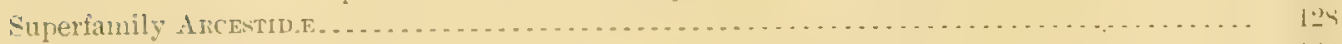

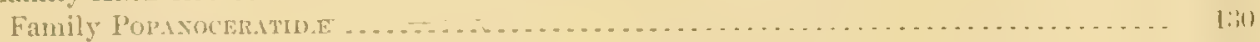

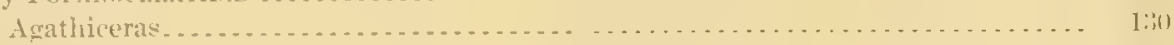

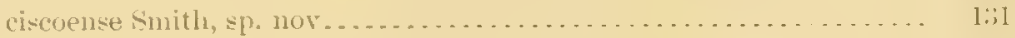

Popanoceras . . . . . . . . . . . . .

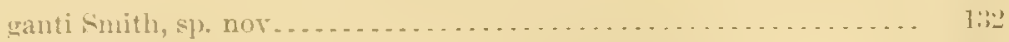

parkeri Ileilprin ...................................

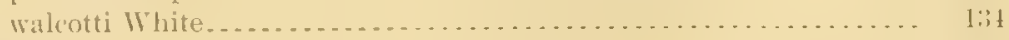

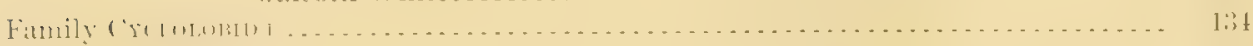

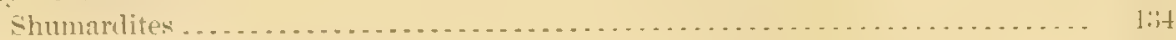

simondsi smith, sp. nov........................

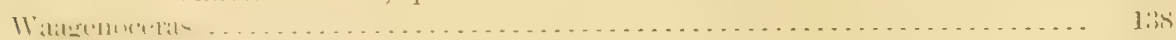

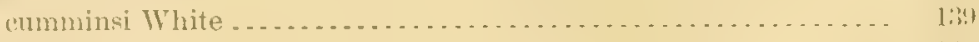

hilli smith, sp. nov .............................. $1+11$

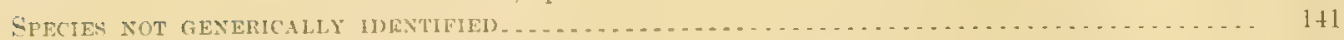

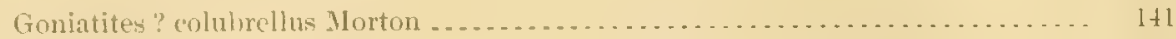

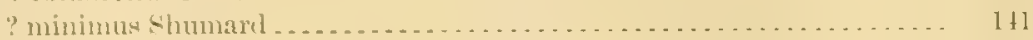

? parvus shumard . . . . . . . . . . . . . . . . . . .

? politus Shumard . . . . . . . . . . . . . . .

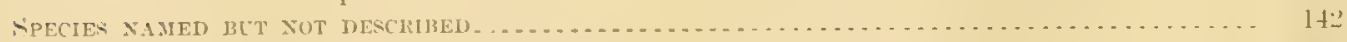

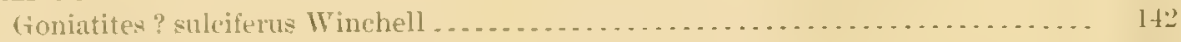

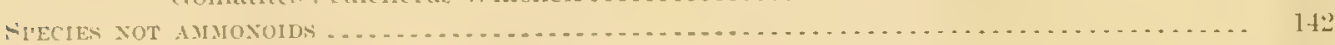

"Ammonites" bellicosus Morton ............................ 14:

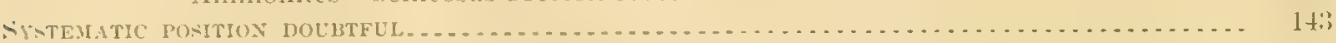

Yeoicoceras elkhornense IIller and Gurley $\ldots \ldots \ldots \ldots \ldots \ldots \ldots \ldots \ldots \ldots \ldots \ldots$ 


\section{DESCRIPTIONS OF' THE SPECIRS.}

\section{Family BACTRITID E.}

\section{Genus Bactrites Saindberger.}

Shell straight or slightly curved, gently tapering, aposs section circular or elliptical. Surface smooth except for the cross strix of growth. Siphuncle mareinal, with long hackward-pointing extensions of the septum, as in Spirula. Septa simple, running nearly straight around the shell, but with a fumel-shaped siphonal lobe.

Bactrites was formerly regarded as a nautiloid, but its siphonal lobe and the calcareous protoconch that has been found on a few specimens. cause it to be classed usually under the ammonoids. The genus has been usually considered as typical of the Devonian, and the species described below is the only authentic species known to oceur in Carboniferous strata.

\section{Bactrites carbonarius Smith, sp. nov.}

$$
\text { Pl. VI, figs. 9-11. }
$$

Shell straight, gently tapering, slender, angle of the increase $5^{\circ} 30^{\prime}$. Cross section of whorl circular. Chambers convex backward, deep, septa close together. The septum runs nearly straight around the shell, but has a slender tongue-shaped siphonal lobe, and short backward pointing siphonal collar. Siphumcle slender, with long backward extension of the septum, as in Spincla; when this extension reaches the extremity of the siphonal lobe it swells out into a knob-like expansion, supposed to represent a periodic repetition of the siphonal cacum. From this contact with the septum a short siphonal collar extends backward into the next chamber. This septum is much more specialized than that of any other species of Buctrites yet described, but this is not remarkable if we consider the fact that the genus has not before been found above Devonian beds.

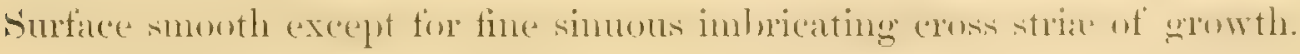

Bactrites was probably the ancestor of the entire ammonoid stock, and thus in it we have a survival of a primitive type occurring along with the 
more specialized descendants of that type This occurrence, however, is of eren greater interest, not as an anachronism, but rather as a forerunner of other forms. Morphologists look to a straight orthoceran ammomoid as the ancestor of the Belemnoidea, but the gap from the Devonian to the 'Trias has been a rather severe tax on the faith of the geologist. Here, then, we have this gap at least partly filled ont by the finding of Bartrites near the top of the Lower Carboniferous.

Occurrence.-St. Louis-Chester stage, so-called "Fayetteville shale" of the Arkansas geological survey, on farm of O. P. Goodwin, near Moorefield, Ark. "The trpe was collected by the writer, and is depesited in his paleontologic collection at Letend stanford Junior Lniversity, Califomia.

\section{Family AGONIATITIDE. \\ Genus Agoniatites Meek.}

The name Agoniatites was proposed by F. B. Meek ${ }^{a}$ for compressed shells with flattenerl sides, narrow abdomens, narrow umbilici, with high and narrow aperture; septa consisting of $\varepsilon$ short abdominal lobe, and a lateral lobe consisting merely of a broad curve. The type chosen was Goniutites expansus Vanuxem.

Agondatites opmes White and Whitfield.

Pl. VII.

1862. Goniatites opimus, White and Whitfield, Proc. Boston Soc. Nat. Hist., Vol. VIII, p. 305 .

1900. Agoniatites opimus, S. Weller, Kinderhook Faunal Studies, II, p. 121, Pl. VII, fig. 8; Pl. VIII, fig. 1; Pl. IX, fig. 1.

The following description is copied from Dr. Weller's paper:

Shell large, discoid, gently convex on the sides, rather sharply rounded on the periphery. Number of volutions not known, the inner ones embraced by the next outer one to a depth of one-half the diameter of the latter; the umbilicus rather small, but somewhat rariable in size, being relatively larger in the larger individuals, its sides rounded.' Aperture compressed erescentic in outline, the proportion of height to width about as 7 to 5 , the ventral margin sinuate as indicated by the lines of growth. The size of the living chamber not known. Septa deeply concare, rather distant, being abont $20 \mathrm{~mm}$. apart in the outer volution of a large individual; 
the sutures forming a low saddle upon the umbilical angle, then gently curving backward and forming on each lateral face a single broad lobe which occupies the entire width of the rolution; the direction of the suture upon the periphery can not be certainly determined, but there seems to be a low saddle on either side, with a shallow ventral lobe between. Position of the siphuncle unknown. Surface marked by faint lines of growth which are sinuate on the periphery of the shell.

Remarks. - In the original deseription of Gonatites opimus, specimens of two entirely different species were apparently used, the general form of the shell being described from one specimen and the suture from another. The specimen bere illustrated on P1. VII, fig. 8 [in Weller's Kinderhook Faunal Studies, II, The Fauna of the Chonopectus Sandstone at Burlington, Iowa], is the type of the species in the University of Michigan collection, and corresponds with original description of the general form and proportions of the shell. 'This specimen, however, does not preserve the suture, and the original from which the suture was described has not been seen. The latter specimen was probably a fragmentary one, not preserving the form of the shell, which was believed to belong to the same species as the type which has been preserved. In the collection received from Prof. Calvin there is a goniatite much larger than the type of $G$. opimus, but agreeing closely with it in its general form and propertions in all respects ave in its relatively largere umbiliens. This specimen is illustrated on Pls. VIII and IX [in Weller's paper cited above], and it is believed to be an indiridual of the same species as the type of $G$. opimus; but, unlike the type specimen, several of the sutures are fairly well preserved, and are entirely different from the sutures of $G$.opimus as indicated in the original description. It is therefore probable that the suture originally described as that of G. opimus is really that of some shell which is not only specifically but generically distinct from $G$.opimus. The true suture of the species is in all respects that of the genus Agoniatites, and therefore the species is placed in that genus. Heretofore this genus has been recognized only in the Devonian, and in America, at least, at no higher horizon than the Middle Devonian.

Occurrence.-Lower Carboniferous, Kinderhook stage, Chonopectus sandstone, Burlington, Iowa.

\section{Family GEPHYROCERATIDE. \\ Genus Nomismoceras Hyatt.}

This genus was establisherl by Iyatt, " with comiutites sprombis Phillips

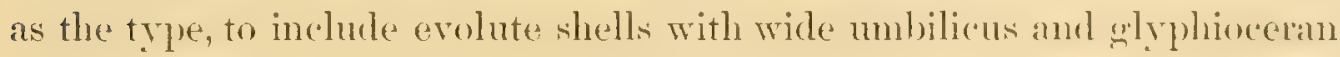
septa; it was regarded as belonging to the Glyphioceratidx, section

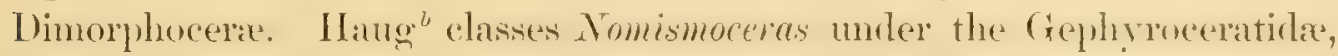
and regards it as the radical of the Meeknceratidar of the 'Trias, the series being Nomismoceras, Paralecanites, Lecanites, Meekoceras.

" Proc. Boston Soc. Nat. Hist., Vol. XXII, p. 330.

${ }^{b}$ Études sur les Goniatites, D. 46.

MON XLII-O $02-3$ 
It is possible that Nomismoceras may be the connecting link between this fimily and I'rolectutes, although it may be a degenerate form of the Glyphioceratidx, to which opinion E. Holzapfel ${ }^{a}$ seems to incline.

Nomismoceras ? Monroense Worthen.

Pl. V, fig. 11.

1890. Goniatites momroensis, A. H. Worthen, Geol. Surr. Illinois, Vol. VIII, p. 150, Pl. XXVI, tig. \$.

Shell discoidal, evolute, compressed, sides slightly rounded, abdomen narrow and sharply rounded. Height of whorl at little greater than width; umbilicus comparatively wide, being about once and a half as wide as the height of the whorl. Umbilical shoulders rather angular and abrupt. Surface of shell smooth, septa consisting of a pair of short rounded lobes on each side, with obtuse saddles.

'The generic reference is very doubtful; the species certainly does not agree with the type of the genus, but probably is as nearly related to it as are several other species that are generally classed under Nomismoceras.

Occurence-Lower Carboniferous, St. Louis stage, Momre, Illinois. Depositer in the Illinois State Museum.

\section{Superfamily PROTFCANTTIDA. Family BELOCERA'TIDE.}

Gemus Prodromites Sinith and Weller.

The type of this genus is $I^{\prime}$. (Goniatites) gorbyi Miller." The type species was originally described as "Goniatites," but a most liberal interpretation of that group could not include this form, which was

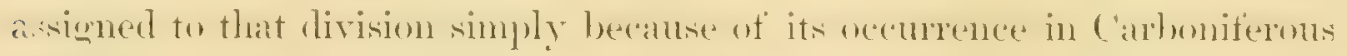
rocks.

The genus Prodromites is characterized by its laterally compressed, discoidal, involute deeply embracing whorls, narow unbilicus, high, hollow aldominal keel, and complex ceratitic septa. Where the keel is broken offe,

\footnotetext{
"Die Cephalopoden des Lomanik im südlichen Timan, p. 21: If́n. Com. gíol. Russie, XII, Yo. 3.

${ }^{b}$ Adrance sheets Seventeenth Ann. Rept. Geol. Surv. Indiana, p. 90, P1. Xr; fig. 1; and Serenteenth Ann. Rept. Geol. Surv. Indian?, p. 700, Pl. XV, fig. 1.
} 
as is usually the case, the abdomen is flattened and angular. 'The surface, as far as known, is smooth, destitute of ribs, constrictions, or other ormamentation. The septation is the most distinctive feature of this genus, on account of the large number of serrated lobes, and extensive auxiliary series of lobes and saddles. The ventral lobe is rather lome and undivided, the saddles all rounded and entire; the first four or five lateral lobes are serrated, and in addition to these there is a series of six or more pointed and more or less irregular auxiliary lobes.

The only Paleozoic genus to which Prodromites may be likened is Beloceras Hyatt, which it resembles only in its compressed involute form and in the multiplication of the elements of the septr 'The resemblance is not great, but the agreement is fundamental, and the two genera may safely be placed in the same family or phylum. A much greater resemblance and probable kinship comects this form with Hedenstremia Waagen, of the Lower Trias of the Oriental region. 'The best known species of that genus is H. mojsisovicsi Diener. ${ }^{a}$ In Hedenstramia, as defined by Waagen, ${ }^{b}$ the ventral lobe is divided, the external saddle is divided by adventitious lobes; the first four lateral lobes are serrated, and there is a series of about six pointed auxiliary lobes. The form is flattened, involute, with narrow and angular abdomen. No keel is known, and the shell is smooth. In Prodromites, on the other hand, the ventral lobe is undivided, and the external saddle is entire and rounded; but in the serration of the first four or five lateral lobes, and in the auxiliary series it is almost identical with Hedenstremia, as also in the form, with the exception of the keel, which may not have been preserved in the few specimens known. 'There can be no doubt that the two genera belong, to the same phylum and even family,

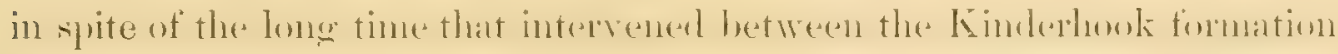
of the Lower Carboniferous and the Lower 'T'rias. Hedenstrumiu (Pl. XXI', fig. 5), according to Wangen, ${ }^{\circ}$ belongs to the family Pinacoceratidx, subfamily Hedenstrominx, which also contains Clypites Waagen, and Camite's Mojsisovies of the Trias. The family Pinacoceratida in the broader sense, as defined by Wagen, contains all forms with compressed involute whorls, an adventitious series of lobes, many lateral lobes and saddles, and an

"Pal. Indica, Ser. XV, Himalayan fossils, Yol. II, Pt. I, Cephalopoda of the Inwer Trias, p. 63, Pl. XX, fig. la-c.

b Pal. Indica, Ser. XIII, Salt Range Fossils, Vol II, Fossils from the Ceratite formation, p. 140.

' Ilirl. 
auxiliary series of lohes ontside of the mbilicus. In this family Waagen

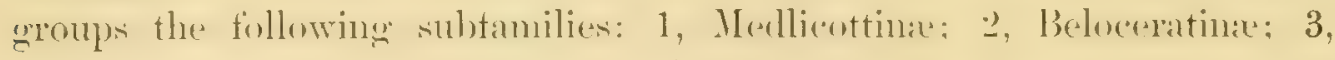
Beneckeinx; 4, Hedenstrominx; all of which have representatives in American Paleozoic or 'Triassic strata.

It is not likely that Prodromites is a descendant of Beloceras, since the septation is quite different in the two genera; and unless Hedenstramia should be found to have a keel, it is not probable that it has descended from Prodromites. Beloceras is commonly placed in the family Prolecanitidx, although it antedates any typical species of Prolecanites. On the

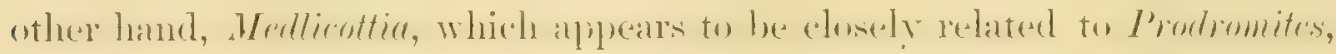
seems certainly to have been a descendant of the typical Prolecantide. No solution of these puestions is possible until the ontogeny of sereral of these genera is known, which is prevented, at present, by a scarcity of specimens. Until other evidence is forthcoming Prodromites is placed

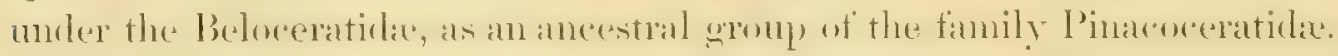

The genus is not founded solely on Miller's figure, which is not accurate, nor even on his type specimens, but also on three other specimens of

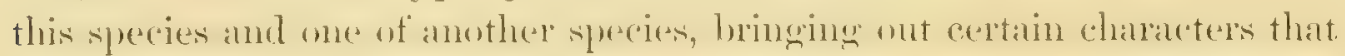
diel not show on Miller's tyles. 'The writer has had at his disposal for stmly four specimens of Prodromites gorbyi Miller, and one of $P$. promuturus Smith and Weller, all of which, except one, belong to the paleontologic

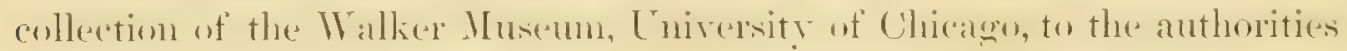
of which the writer's thanks are due for the use of the specimens. The first specimen, No. 6208, ${ }^{a}$ is Miller's type of Goniatites gorbyi, and came from the Choutean linestone, I'in IIonk Bridee, Pettin County, IIo. A

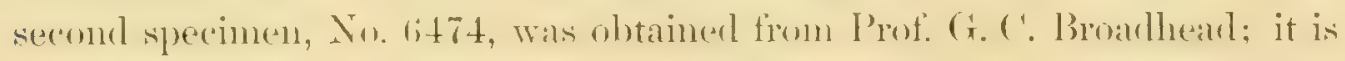
better preserved than the type, but is in the same sort of limestone, and while it is merely labeled "Chouteau limestone, Pettis County, Mo." it probably came from the same locality as the type. A third specimen, No. 672: is recorderl merely from the Kinderhouk stage of Burlington, Iowal. The material in which it is preserved is a buft or yellowish, rather finely crystalline limestone, the position of which in the Kinderhonk section at Burlington is probably near the top, between the oolitie limestene and the buft magnesian berd, which lies immediately below the Burlington limestone, 
of Osage age. 'This horizon may then be correlated with the Chontean limestone of central Missouri.

A fourth specimen of Prodromites gorlygi was studied in the collection

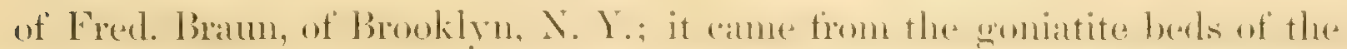

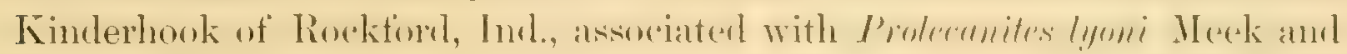

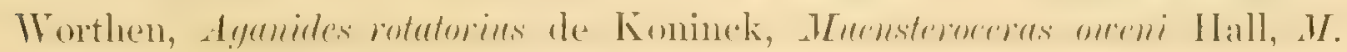
parallelum IIall; thus it is certainly in the zone of Iganieles rotatorius of thes

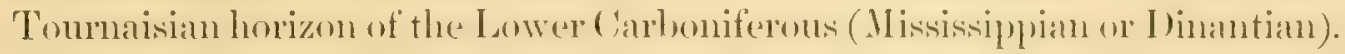

A fifth specimen of the genus, No. 6223, belongs to a new species, (I'. prematurus Smith and Weller); it cane from the goniatite heds of the Kinderhook of Rockford, Ind.

Occurrence.-Since this genus occurs in the same horizon, in rocks

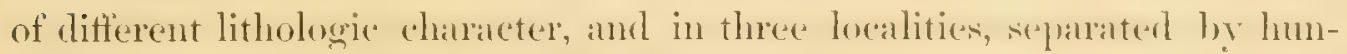

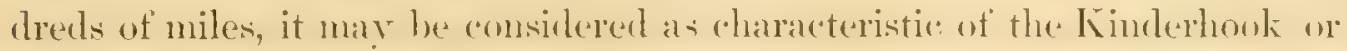
Choutean horizon of the Lower ('arboniferous, equivalent to the lower part of the Toumaisian division of the European Dinantian formation. At

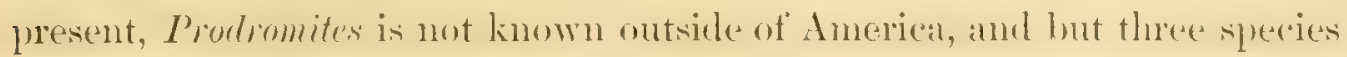
are known, in the Mississippi Valley region, from the three localities inentioned.

\section{Prodromites gorby Miller.}

Pl. XXIII; Pl. XXV, figs. 1, 2.

1591. Goniatites yorbyi, S. A. Miller, Adrance sheets Serenteenth Ann. Rept. Geol. Surr. Indiana, p. 90, Pl. XV, fig. 1.

1892. Goniatites gorbyi, S. A. Miller, Seventeenth Ann. Rept. Geol. Surv. Indiana, p. $700 ;$ Pl. XV, fig. 1.

1901. Prodromites gorby, Smith and Weller, Jour. Geol., Vol. IX, No. 3, p. 259, P. VI, tig. 1: P'. VII, fig. 1: P'. VIII, tigs. 1 and :.

Neither the description nor the figure of this type given by Miller is accurate, the drawings of the septa being much tou gencralized. 'The form is laterally compressed, involute, discoidal, with very narrow unbilicus. The abdomen is narrow and sumounted by a high hollow keel, which, however, is not usually preserved. Where the keel is broken away the abromen is narrow, less than a millimeter wide, with angular arders. 'The

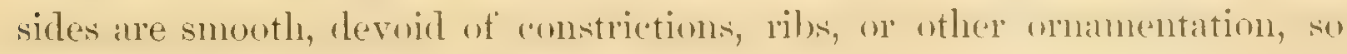
far as could be determined from the casts.

The septa are complex, ceratitic, with many lobes and saddles. 'The 


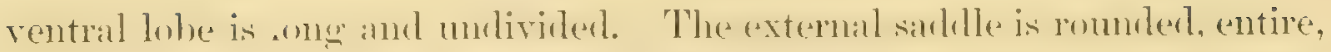
and shorter than the laterals. The first lateral holye in serrated, four-pointerl: the second four-pointed; the third, three-pointed; the fourth, irregularly three-pointerl: the tifth, imeoularly hifirl. With the sixth lateral lobehegins the auxiliary series of goniatitic lobes, which are of irregular size, and eight in number at maturity, growing smaller toward the umbilicus. These characters could not be made out distinctly on Miller's type, but the details were clearly seen on $\mathrm{No} .6474$, from the same locality. The differences between the two specimens might seem, at a casual glance, to be specific, but closer study shows them to be due to difference of preservation, and to different sizes at which the septa are seen. The type specimen shows the keel at only a fer places on the periphery, and so indistinctly that Hiller overlooked it, while No. 6474 shows the keel, $31 \mathrm{~mm}$. high, entirely around the periphery. On both specimens the body chamber is incomplete and occupies a little over a fourth of the last revolution. It is not known what was the shape of the aperture, how long the body chamber was when the keel began, nor what the internal lobes were like, since none of the speci mens available sufficed to answer these questions.

A smaller specimen, No. 6222, from the Kinderhook beds, of Burlington, Iowa, showed much simpler septa and the narrow angular abdomen

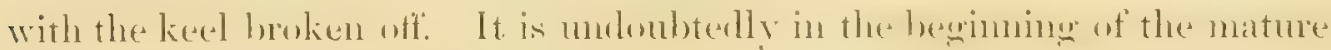
stage of growth, and is of value in showing the shape of the cross section, since the sides were free from the matrix.

Occurrence.-At present there are known only five specimens of Prodromites yorlyji, ail from the same horizon, Kinderhook or Chouteau stage zone of Ayanides rotatorius of the Lower Carboniferous, equivalent to the Tournaisian horizon of the Dinantian formation of Europe, viz:

1. Miller's type, from the Choutean limestone of Pin Hook Bridge, Pettis County, Mo. No. 6208, paleontologic collection, Walker Museum, University of Chicago (Gurley collection). This specimen is the type of the genus Prodromites Smith and Weller (Pl. XXIII, fig. 1).

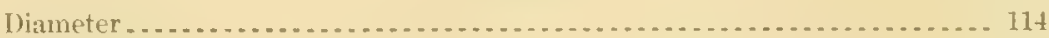

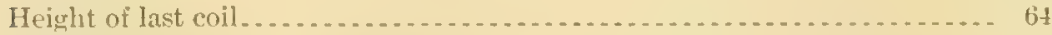

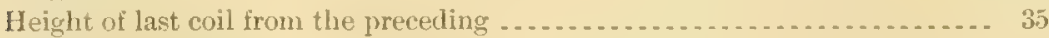

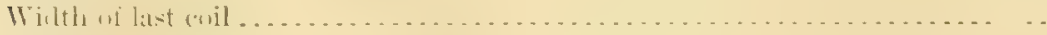

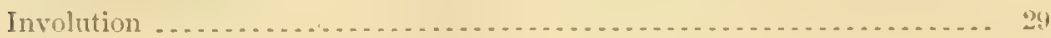

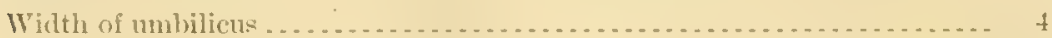


2. Specimen obtained from Prof. G. C. Broadhead, Chontean limestone, Pettis County, 1 o. probably from the same locality as the last, No. 6474, paleontologic collection, Walker Musemm, University of Chicago (Pl. XXIII, fig. 2).

\section{limensions.}

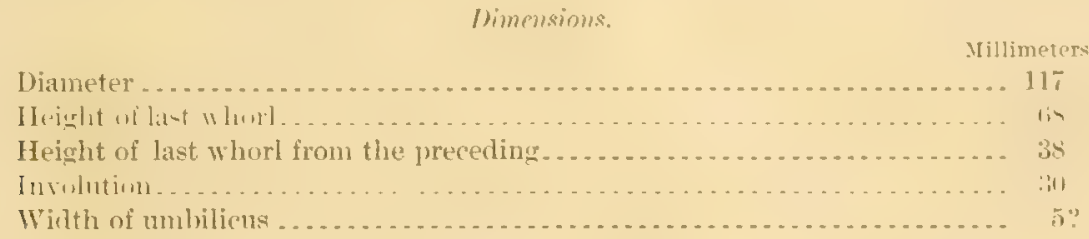

3. Specimen from the Kinderhook limestone of Burlington, Iowa, between the oolitic limestone and the buff magnesian bed that lies immediately below the Burlington beds of the Osage stage. No. 6222, paleontologic collection, Walker Museum, University of Chicago (Pl. XXV, figs. 1 and 2)

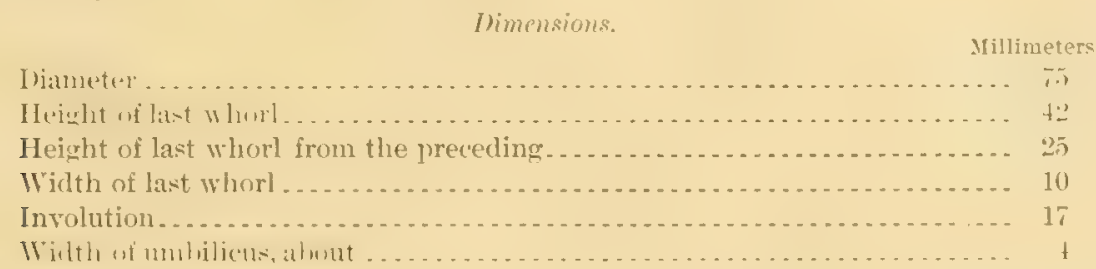

4. Specimen from the goniatite beds of the Kinderhook of Rockford, Ind.; in the paleontologic collection of Fred. Braun, of Brooklyn, N. Y., where it was examined by the writer. Its dimensions are about the same as of the two specimens from Missouri.

5. A specimen from this species is said to be in the U. S. National Museum, but it has not been seen by the writer.

P'rodromites ornatus Smith, sp. nov.

Plate XXI, figs. 6-8.

Form discoidal, involute, laterally compressed. Whorls deeply embracing, and deeply indented by the inner volutions. Cross section of the whorl high and narrow, with flattened sides and acute venter, surmounted by a sharp, narrow keel. The umbilicus is almost entirely closed, and without umbilical shoulders: 'The height of the whorl is somewhat more than one-half of the total diameter of the shell, and the breadth is one-fourth of the height; it is indented by the inner volution to one-half of 
its height. The surface of the cast is omannented with sigmoirlal ribs, which bend backward toward the venter. These rils are fine and sinuous, showing with unusual distinctness on the cast. The outer shell is unknown, but they should be even more distinct on it.

Septa ceratitic, lanceolate. The ventral lobe seems to be undivided, the first lateral is indistinctly tripartite, the second lateral distinctly sermated, and the third is bifid; these are followed by a series of six unserrated auxiliary lobes, growing smaller and shorter toward the umbilicus.

From its small size, its shape, and the primitiveness of its septa, this speremen might be considered as the young of Prodromites gorbyi, but in all known specimens of that speceies the surface of the cast is perfectly smooth. It moloubtedly belongs to that genus, and is perlatps the romger of some unknown form, but probably not that of Irodromites gorbyi, nor of $P$. prometurn: a name is therefore given to it by which the mature form may be known when it is discovered.

Only a single specimen is known, No. 7682, paleontologic collection, Walker Husemm, Tniversity of Chicago. The writer's thanks are dur Dr. Stuart Weller for the use of the type. Diameter of the type, $28 \mathrm{~mm}$.

Occurrence.-Lower Carboniferous, Kinderhook stage, Chouteau limestone, Pettis County, Mo.

Prodromites prematurus Smith and Weller.

Pl. XXV, figs. 3 and 4.

1901. Prodromites prematurus, Smith and Weller, Jour. Geol., Vol. IX, No. 3, p. 261, Pl. VIII, figs. 3 and 4 .

Type of species is specimen No. 6223, paleontologic collection, Walker Museum, University of ('hicago (Gurley collection). Fom laterally compresserl, discoidal, involute, deeply embrang, with namm umbilicus, narrow, slightly flattened abdomen surmounted by a hollow keel $3 \mathrm{~mm}$. high. Whorl indented by the preceding whorl to a little over onethird of its height. Surfice smooth, so far as known.

The septa are complex, ceratitic, with rounded, entire saddles, serrated lateral lobes, and a series of auxiliaries above the umbilicus. 'The ventral lobe is narrow and undivided; the first lateral is lomger and thres-pointed; the second lateral, four-pointed; the third lateral, bifid; the fourth lateral, lifid: then begins a series of anxiliary lobest undivided and printed, seven in number. 
The only species with which Prodromites promaturus might be com-

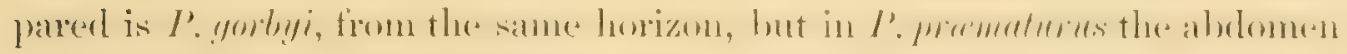

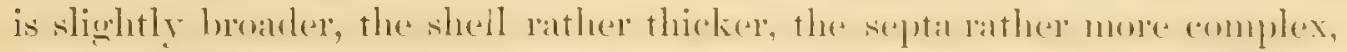
and the umbilicus slightly wider than on $P$.gorbyi at the same diameter. In the figures and deseriptions of the septat a diflerence between the two species may easily be seen.

\begin{tabular}{|c|c|}
\hline Diameter. & $\begin{array}{c}\text { Millimeters } \\
6: 2\end{array}$ \\
\hline Ie ight of last whorl. & 34 \\
\hline Height of last whorl from the preceding........... & 21 \\
\hline Width of last whorl .......... & 9.5 \\
\hline Involntim.. & $1: 3$ \\
\hline Wisth of umbiliness & is. .5 \\
\hline
\end{tabular}

This specimen was septate throughout, and when complete must have been much larger.

Occurrence-Only a single specimen is known, No. 6223 of the paleontologic rollection, Walker Musem, Eniversity of ('hicanen, trom the Lower Carboniferous, Kinderhook limestone, goniatite herds of Rockford, Ind., near the base of the Mississippian series.

\section{Family PRONORITID E.}

As it is now generally admitted that Pronorites and its allies can not be classed under the family Prolecanitidx in the strictest sense, some new designation for this group ought to be given. E. Hauge" proposed the name Iberegiceraticla for this phylum, but the genus on which the family was foumled, Ibergireres, has since been shown to be merely an inmature form of Pronorites cyclolobus. Since Pronorites is the principal genus of this group, and is the ancestor of a large number of genera that occur in the Permian and Trias, the writer proposes to call the family Pronoritidre,

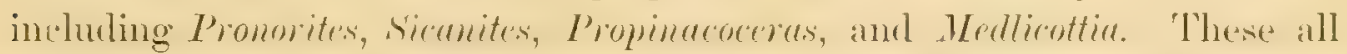
seem to have been derived from Paraprolecanites, which may then be considered as the family radicle: F. Frech" has used the term l'rommitinat for this group, regarding it as a subfamily.

\section{Genus Pronorites Mlojsisovics.}

In the adult stage Pronorites is discoidal, has high, narrow whorl, with nearly parallel sides, is very involute, and has narrow umbilicus.

The siphoual lobe is three-pointed, the first lateral lobe divided into 
two or three parts by secondary simuses. In addition to these there are sereral anxiliary lateral lobes, three to six, all slightly pointerl, while all the saddles are rounded. No constrictions or other surface ornamentations are known, exeept that on the alult borly chamber faint rils have been observert.

The first septum of Pronorites is latisellate, and the broad sinus is soon divided by a siphonal lobe into two lateral simuses (Pl. XII, fig. 1). 'This is the end of the embryonic stage, in which the shell is seen to belong to an ammonoid cephalopod, but the family is not yet indicated.

In the next stage the lateral sinuses me subdivided by broad, rounded lobes; the sutures then resemble those of Goniatites (Ibergiceras) ${ }^{a}$ tetragoms Roemer, and the shell is in the beginning of the larval or nepionic stage; a little further on the sutures are like those of a Prolecanites (I'. serpentimus Phillips), and the larral stage is approaching its end.

In the following or neanic stage the siphonal lobe becomes threepointed, and the shell corresponds to Paraprolecanites Karpinsky, and its family aftinities are beyond doubt (PI. XIII, fig. 5).

With the adult or ephebic stage the first lateral lobe becomes divided into two or three parts (Pl..XIII, fig. 5c-f). With this stage the genus

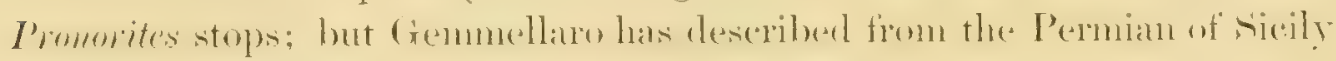
a further development of this series in the genus Parapronorites, in which the double lateral lobe and some of the simple ones become serrated.

Another line of development of Pronorites has been described by Gemmellaro as Sicanites, in which all the lateral lobes become double like the first one. The next higher stages are given by Merllicottic Waagen, in which the siphonal saddles become indented and ammonitic. Karpinsky ${ }^{b}$ shows that Medlicottia in its development goes through the Ibergiceras, Prolecanites, Paraprolecanites, Pronorites, Sicanites and Promedlicottiu stages.

Pronorites is represented in America by two species, one in the upper part of the St. Louis-Chester stage, and one in the Middle Coal Measures, both in Arkansas. The finding of Pronorites in Arkansas is of great importance, since it is the ancestor of Medlicottiu, which, though monkown in Arkansas, has been found at no great distance away in the Texas l'ermian. Pronorites. on the other' hand, has not yet been found in 'T'exas.

"Holzapiel has recently shown in Die Cephalopoden des Domanik in südlichen Timan, p. 45, that Ibergiceras tetragonus Roemer is merely a young stage of Pronorités cyclolobus Phillins, and came from the Carboniferous limestone instead of from the Devonian strata of the Hartz.

b. Ammoneen der A-tinsk-Stufe, p. 41. 
These occurrences help to prove the continuity of life from the Carboniferous into the Lermian, and to show that the same conditions existed here as in the Artinsk region of the Ural Mcountains, where the Carboniferous beds contain the goniatites out of which most of the Permian ammonites were developed.

\section{Pronorites cyclolobts Phillips, variety arkansasensis Smith}

$$
\text { Pl. XII, figs. 12-15. }
$$

1836. Goniatites cyclolobux, J. Phillips, Geol. Yorkshire, Pt. II, p. 237, PI. XX. figs: $40-42$.

18tó. Goniatite's cyclolobus, Murchison, Verneuil, and Keyserling, Géol. Russie d'Europe, ete., Vol. II, p. 370, Pl. XXVII, fig. 4.

1855. Goniatites cyclolobus, F. A. Roemer, Palaentographica, Vol. V, p. 167, Pl. XXVII, fig. 1 (not Pt. II, p. 95, Pl. XIII, fig. 34).

1860. Goniatites cyclolobus, F. A. Roemer, Palæontographica, Vol. IX, p. 11, PI. IV. figs. $1, a, b, c$.

1850. Goniatites cyclolobus, L. G. de Koninck, Faune calc. carbon. de la Belgique, Vol. 1, p. 273, Pl. L, tigs. 5, 6.

1882. Pronorites cyclolobu, E. yon Mojsisovies, Cephalop. Mediterranen Triasprorinz, p. 201.

185t. Pronorites cyclolobus, A. Hyatt, Proc. Boston Soc. Nat. Hist., Vol. XXII, p. 337.

185t. Pronorites cyclolobus, K. A. von Zittel, Handbuch der Palæont. Vol. II, p. 421 , tig. ist.

18s8. Goniatites cyclolobus, R. Etheridge, British Fossils, Vol. I, Palrozoic, p. 311. 18s\%. Pronorites cyclolobus var. uralensis, A. Karpinsky, Ammoneen der ArtinskStufe, p. 8, Pl. I, tig. $t$.

1890. Pronorites cyclololus, Steinmann and Döderlein, Elemente der Palïont., p. 395 , fig. 475 .

1895. P'ronorites cyclolobus, K. A. von Zittel, Grundzüge der Palæont., p. 400. fig. 1059.

1896. Pronorites cyclolobus var. arkensasensis, J. P. Smith, Proc. Am. Philos. Soc., Vol. XXXV, p. 267, Pl. XXIV, figs. 1-t.

1897. Pronorites cyclolobus, Foord and Crick, Catal. Foss. Ceph. Brit. MIus., Pt. III, p. 26 , fig. 125 .

1900. Promorites cyclolubus, A. Hyatt, Cephalopoda, p. 562, fig. 115t. (NotGoniatites: cyclolobus Barrois, Mém. Soc. Géol. du Nord, Vol. II. p. 295, Pl. XIV. fig. :, a-c=Pronorites bamoixi Karpinsky.)

Phillips's original description of Goniatites cyclolobus is as follows:

Dissoid, sides that, back broad, inner whorls half concealed, septa with four round lateral lobes. a small double dorsal lobe. and small acute dormal sinuses. the first lateral sinus double, the others simple, all round.

This description is too meager to be of more than generic value, and also the term "dorsal" is user where now "abdominal" is in common use.

The shell is smooth, discoidal, very involute. The sides are nearly 
parallel and the breadth increases very slowly; the abdominal shoulders are nearly square, and the abdomen flat. The whorls are deeply embracing and increane rapidly in height. The umbilical shouders are square, the umbilicus narow and deep, and increases slowly in diameter.

Dimensions.-The specimen, which was septate throughout, gave the following dimensions:

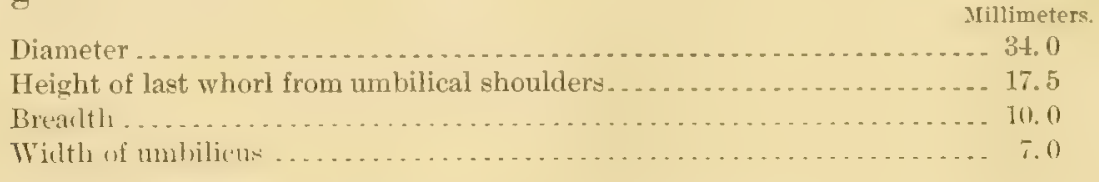

This gives the proportions: $1: 0.5: 0.29: 0.20:$ which agree almost exactly with Karpinsky's figures, $1: 0.5: 0.30: 0.20$. On the Arkansas specimen the involution is shown by the height of the last whorl from the top of the next inner one, $12.5 \mathrm{~mm}$. as compared with the total height of the whorl, which is $17.5 \mathrm{~mm}$. Nomeasurements of this relation were shown on the Russian specimen.

This deseription applies only to the adult shell, the relative measurements of the nepionic and neanic shells being rery different. The Arkansas specimen showed only the last whorl, but the young stages lave been worked out by Karpinsky," from whose work the following description is translated:

Around the cylindrical embryonic chamber [PI. XIII, fig. 2] are coiled very evolute whorls, whose involution increases gradually, but at first only in slight measure [PI. XIII, fig. 4 ]. So, for example, the fourth whorl embraces at the beginning only ahout one-fourth of the preceding; thus the height of the evolute portion of this fourth whorl is six or seven times as great as that of its own involute portion.

With later stages of growth the involution increases so that the whorls become finally completely embracing, and probably conceal a portion of the umbilicus. Because of this mode of growth the umbilicus appears at first broad, and increasing rapidly, then only gradually, and finally not at all. while the whorl continues to grow in height with great rapidity. Thus, at a diameter of the whorl of 4 or 5 millineters, the umbilicus is abont one-half of the total diameter, and at 30 millimeters only about one-tifth. The first and second whorls have a broad elliptical cross section [Pl. XIII, fig. :3. while that of the succeeding whorls become- higher, with the lomg elliptical axis vertical [Pl. XIII, fig. 2], and then finally the flanks are bounded by almost parallel lines and the siphonal side is only slightly arched.

Ontogeny.-According to Karpinsky the first or typembryonic stage is latisellate-that is, the suture consists of a broad aldominal saddle; this saddle is mext divided by a broad siphonal lobe (Pl. XII, fig. 1). 
The next stage corresponds to the supposed genus rbergiceras Kar-

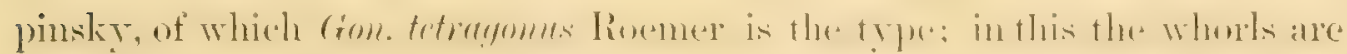

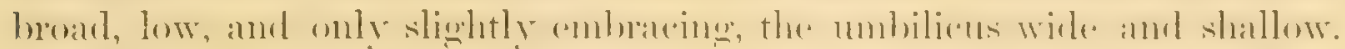

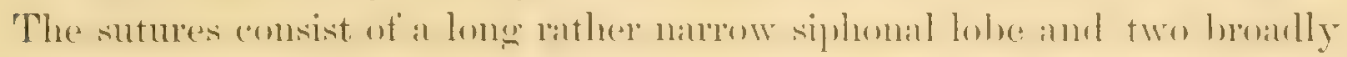
rounded lateral lobes. 'This is the nepionic or larval stage (Pl. XIII, fig. 5a). In the continuation of this stage the whorls become higher and the lobes more complicated, corresponding to the genus Prolecanites, of

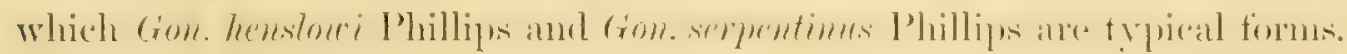

In the next stage the shape of shell does not change materially, but the siphomal lohe becomes three-pointed (I'I. XIII, tign. 5): this is the neanic

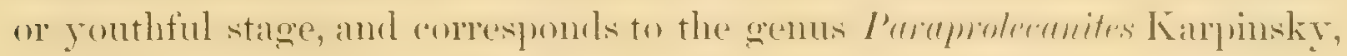
of which the type is Gon. mixolobus Sandberger (not Phillips). ${ }^{a}$

The further development consists in the division of the first lateral

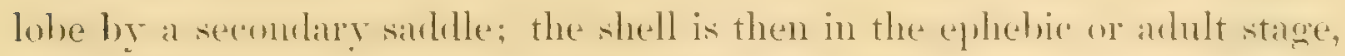
and in Pronorites gets no higher in its development.

The sutures are then constant in shape, and consist of a three-pointed siphomal lobe, a first lateral lobe deeply divided hy a secomdary saddle and five secondary lateral lobes outside the umbilical bordere, and me on the umbilial shoulder. All the lobes are pointed, and the saddles rounded. The inner lobes, covered by the involution, are unknown.

The sutures, as figured on Pl. XII, fig. 15, show some differences from those figured by Ihillips, I'l. XII, fig. 3, amd hy Karjunsy, Pl. XII, fig. 5. On the Arkansas specimens the three-pointed siphonal lobe is longer than on the type of Phillips, or the form $P$. cyclolobus variety urelensis Karpinsky, the secomblary sinus on the first lateral lobe is dereper, and the secomd lateral lobe is propurtionally lomere. In this the Arkansas specimen does not depart further from the type than the variety uralensis. This differenee was thought to be of sufficient impurtance to charareterize a new variety, and the name $P$. cyclolobus Phillips, variety arkansasensis was proposed in 1896.

Surface markings.-The shell is smooth and devoid of constrictions or other ornamentation, but on the body chamber of the adult Karpinsky observed weak ribs that are stronger on the abdomen and grow weaker toward the umbilicus.

"Verstein. Rhein. Schichtensystems in Nassau, p. 67, Pl. III. fig. 13"; P1. IX, tig. 6. 
Affinities.-This species is certainly a variety of Pronorites cyclolobus Phillips," but is more involute at the correspomling dianeter, and has at narrower umbilicus and a greater number of lateral lobes. Specimens described by de Koninck ${ }^{b}$ from Belgium, and by Roventere from the Hartz

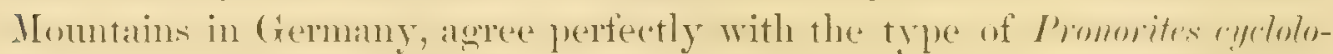
bus; the English, Belgian, and German beds, in which the species was found, are all in about the same horizon as the bed in which it was found

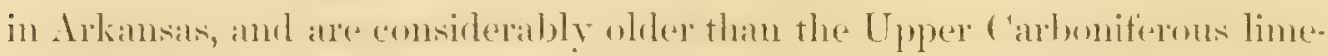
stone in whel it was found in the Ural Mountains. From this Karpinsky ${ }^{d}$ thinks the variety uralensis represents a mutation from the type of the species.

The form from the Pyrenees described by Barrois ${ }^{e}$ as Goniatites cyclolobus Phillips has been shown by Karpinsky to be a new species, I'. barroisi Karpinsky. 'This form is more evolute than even the type of $I$ '. cyclololus, and its lobes and saddles are broader and also less numerous.

Occurrence.-I'ranorites cyclolobus Phillips, variety arkansasensis Smith was found with Gastrioceras brameri Smith in Arkansas, on Pilot Mountain, Carroll County, 3욜 miles southwest of Valley Springs, in T. $17 \mathrm{~N}$, R. $19 \mathrm{~W}$, sec. 18, northeast comer, near the junction of the Chester limestone of the Lower Carboniferous with the Lower Coal Measures or "Millstone grit," but probably in the Chester stage, judging from the occurrence of Productus cestriensis Meek and Worthen in the same beds with the goniatite. 'The beds are called A 10 in Prof. H. S. Williams's section; below them lie 55 feet of micaceous sandstones and shales (A 9 of the section), and below that coarse, reddish-brown fossiliferous limestone, belonging to the Chester stage of the Lower Carboniferous

'The type figured on Pl. XII, figs. 12-15, is the property of the U. S. Geological Survey (National Museum), locality number 1275.

Pronorites cyclololus has been found in Fingland in the upper part of the Mountain limestone; in Belgium in the limestone of Visé; in Germany in the Kohlenkalk of the IIartz; and the variety uralensis has been found in Russia in the Upper Carboniferous limestone of the Ural Mountains in (: 2 of the section.

\footnotetext{
"Geol. Yorkshire, Pt. II, p. 237, Pl. XX, figs. 40-42.

${ }^{b}$ Faume calc. carbon. de la Belgique, Vol. I, p. 273, Pl. L, figs. 5 and 6.

c Palseontographica, Vol. IX, p. 167, Pl. XXVII, tig. 1.

"Ammoneen der. Artinsk-Stufe, p. 10.

e Mém. Soc. Géol, du Nord, Vol. II, No. 1, p. 295, II. XIV, fiy. 2.
} 
Pronorites stementhali Smith, sp. nov.

Pl. XI, figs. 5-7.

1896. Pronorites sp. indet., J. P. Smith, Proc. Am. Philos. Soc., Vol. XXXV, p. 260 , Pl. XX, tigs. $2 \mathrm{a}-\mathrm{c}$.

In the Middle Coal Measures of Scott County, Ark., 'T.1 N., R. 28 W., ser.

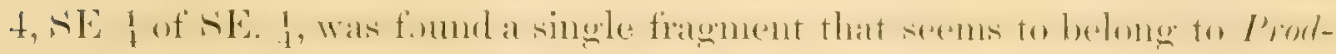

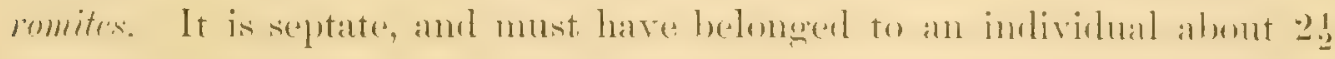
inches in diameter. The sides are smooth and little embracing and almost parallel; the coil is thin and discoidal, and the ventral or external portion seems to be only slightly arched. From the umbilicus toward the ventral portion are seen five lateral lobes that are long and pointed, the saddles being somewhat rounded. 'The siphonal lobe and part of the first lateral lobe are not seen, that part of the shell being worn so that they can not be made out, but enough of the first lateral lobe is visible to show the secondary saddle that divides it. The septa are very close together, as seems to be the case on all species of this genus.

The nearest known relative is Pronorites cyclolobus Phillips, var. uralensis Karpinsky. ${ }^{a}$ The lobes figured on Pl. I, fig. 4, of Karpinsky's monograph are very like those of the specimen from Scott County, and the general shape of the coil, the height, and the amount of the involution are about the same on both.

Occurrence.-Middle Coal Measures, Scott County, Ark., T'. 1 N., R. 28 W., sec. 4 .

Genus Medicottia Waagen.

It was once thought that ammonites were not found below the Mesozoic, and that all the Paleozoic ammonoids were goniatites. A survival of this idea is seen in Dr. C. A. White's description of the Permian ammonites of 'T'exas as "Mesozoic types." But to-day it is recognized that ammonites are quite as characteristic of the Permian as of any later formation.

Medlicottia was one of the first Paleozoic ammonites to be described, a species of this genus having beeu published by IIurchison, Vemenil, and Kegrerling" undere the name croniutites ablignyenus, from the Artinsk formation, Lower Permian, of eastem Russia. 
Since that time species of this genus have been found in the Perminn of India, Sicily, and 'T'exas, and one species has recently been lescribed by Diener ${ }^{a}$ from the Lower 'Trias, so that it is no longer to be regarded as exclusively Paleozoic.

As to the systematic position of this genus there is no doubt, for Karpinsky ${ }^{b}$ settled that question by his researches in the ontogeny of Medlicottia, Pronorites, and kindred forms. The only question now is

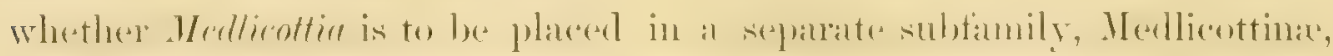
or whether the larger group, Prolecanitidx, shall be retained. Waagen regards the latter group as a suborder.

\section{MedLICOTTIA COPEI White.}

Pl. XXII, figs. 1-3.

1889. Medlicottia copei, C. A. White, Am. Nat., Vol. XXIII, p. 117, I'I. I, figs. 1, 3. 1891. Medlicottic copei, C. A. White, Bull. U. S. Geol. Survey No. 77, 1). 21, PI. I, tigss. 1, 3.

1901. Medlicottie copei, F. Frech, Die Dyas, p. 512, figs. 1 and 2.

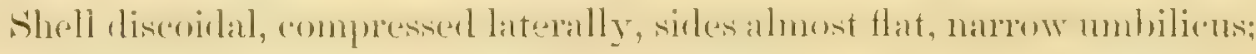

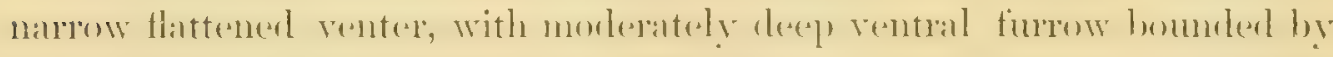

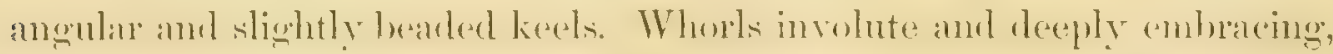
becoming more so as age advances. "Surface almost smooth, ornamented with fine curving cross ribs; the spiral ribs or striac that are found on some species of Medlicottia have not been observed on the Texas specimens. The septa are complex, as is always the case with this gemus. 'The siphonal lobe is long and narrow, with a number of small denticulations on the sides. The external saddle is deeply digitate and rather broad. 'The

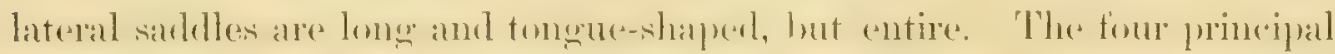
lateral lobes are narrow and deeply bifid. There are also about eight auxiliary lateral lobes, of which the two highest upon the sides are bifid, and those nearer the umbiliens modivided, thus exemplifying Jackson's law of localized stages of development.

Occurrence.-In the Permian of Baylor County, 'Tex., at the military crossing on the Big Wichita River; also near San Angelo, 'Tom Green County, 'Tex. 
Since this genus is so widely spread and so characteristic of the Permian, this horizon has been called the zono of Medlicottio. Closely related species have been found in the same horizon and in approximately the same association in the Artinsk formation of the Ural Mountains; in the Productus limestone of the Salt Range of India; in the Fusulina limestone of Sieily; and in the Wichita formation of northern Texas.

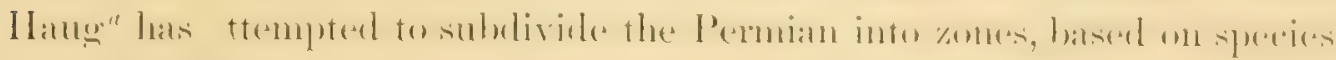
of Medlicottia, but this is impracticable, since these species are not inter-

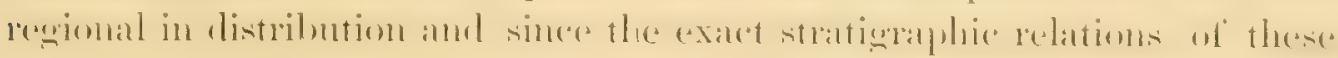
beds in various parts of the world are not yet known.

\section{Family NORITIDA.}

Genus Schuchertites gen. $110 \mathrm{v}$.

F'orm discoidal, laterally compressed; sides flattened; abdomen narrow, angular, and channeled. Close coiled, involute, with narrow umbilicus. Surface deroid of ribs, constrictions, and other ormamentation, except curved cross stria of growth, forming gentle undulations on the shell.

Septr ammonitic and complex, with numerous lobes and saddles.

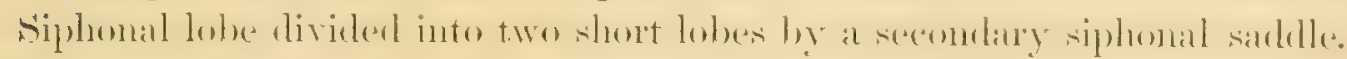
First lateral saddle diveled by a shert rounded indentation or arlventitions lobe; all the other saddles rounded and entire. Lobes somewhat digitate and club-shaped, constricted at the upper portion. The septa, instead of

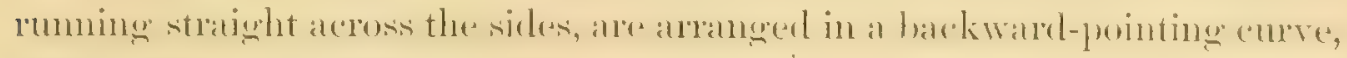
parallel with the strix of growtl.

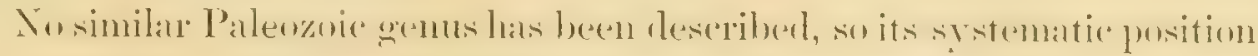
is somewhat doubtful, especially since the young stages of the shell are unknown. But the compressed, involute, discoidal form and the compli-

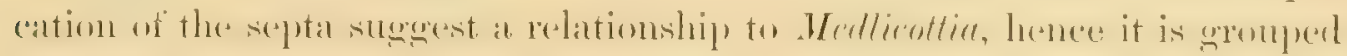
near that genus under the superfamily Prolecanitida, and doubtfully referred to the Noritida. The shape of the whorl, the character of the

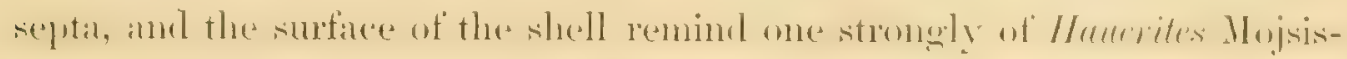
ovics, of the Upper 'Trias, but Schuchertites is much too complex to have been the ancestor of that genus; it is probably only a case of parallelism, in accelerated development from a kindred stock. 
No Permian forms are known that could have developed out of this menus, so probalbly it is the end of a series which itself is at present monown, for I'rmorites conld not have been the ancestor, and this is the only involute riscoidal member of the Prolecanitidx known from the Carboniferous. This wenus is the most highly specialized form known in the ('arboniferous, and is as complex as any yet described from the Permian. The occurrence of such forms sugrests the great galps that exist in our knowledge of the Paleozoic ammonords, and inspires the hope that eventmally these galps will be filled out.

Occurrence-Schuchertites is at present known only from the Upper Coal Measures, the type of the genus, Schuchertites grahmi sp. nov., being known from only a single locality, Graham, Tex. Named in honor of Mr. Charles Schuchert, of the U. S. National Museum.

\section{Schuchel:tites grahami Smith, sp. nov.}

Pl. XXI, figs. 20-22.

This species, represented by only a single imperfect specimen, U. S.

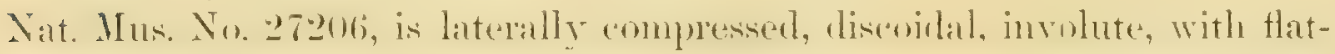
tened sides, narrow umbilicus, and narrow elammeled abrlomen. Surface so far as known is devoid of ribs and constrictions, but has fine curved cross strix of growth, forming gentle undulations on the shell.

The septa are complex and ammonitic, divided into eight lobes and saddles. The siphomal hole is divided ly a short angular weondary sudtle; the first five lateral lobes are undivided and digitate, and there are three simple auxiliary lobes, not digitate, but club-shaped. The first lateral saddle is divided by a short rounded secondary lobe, the other lateral saddles are undivided, and rounded at the extremities. The lobes are sharply constricted at the mprer portion, giving a club shape to the lobes

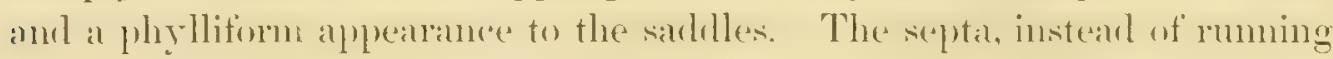
in a straight line across the sides, are arranged in a backward-pointing curve, parallel to the strix of growth. Internal septa unknown.

Occurrence--Upper Coal Ieasures, Graham, Young County, 'Tex., about a thousand feet below the Permian, associated with a typical Upper Coal Measures fama. Collected by A. B. Gant. 


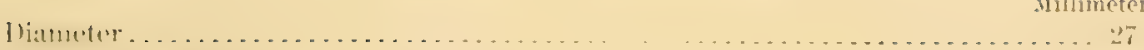

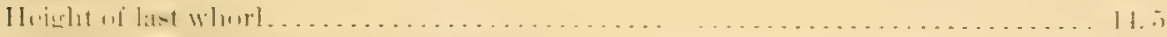

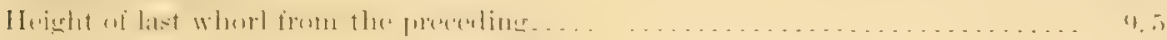

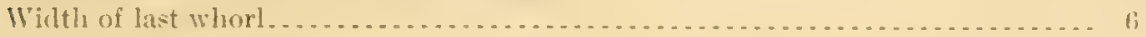

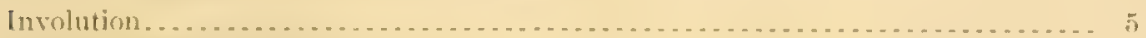

IVilth ai umbiliens, almont.

The specimen was septate throughout, and must, if complete, hare reached at least twice this size.

\section{Family PROLECANITIDE s. str.}

In this paper the superfamily Prolecanitidx is used in the broad sense, as it was by Karpinsky, and is thus equivalent to Hyatt's superfamily Prolecanitidu. 'The family name Prolecanitide is applied only to the immediate allies of Prolecanites. E. Hang " has recently proposed to sub-

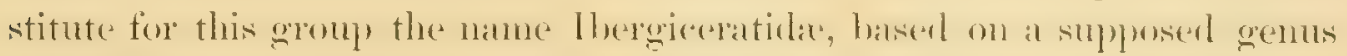

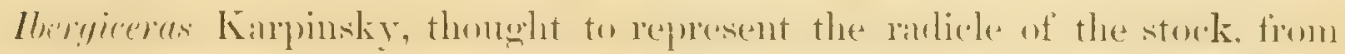
which Prolecanites, Puraprolecanites, and Pronorites came. But Holzapfel ${ }^{b}$ has shown that the genus Ibergiceras, (Gon. tetragonus Roemer) was based merely on a young specimen of Pronorites cyclolobus, and came, not from the Ievonian, but fiom the Lower (arboniferoms linestone of the Ihereg in the Hartz.

\section{Genus P'rolecanites Mojsisovics.}

The genus Prolecanites was named by Mojsisovics ${ }^{e}$ to include evolute, compressed forms, with wide umbilicus, slightly embracing whorls, and goniatitic, lanceolate septa. 'The extermal lobe is undivided, the two or thres lateral lobes pointed and tongue-shaped. The saddles are spatulate and rounded. The antisiphonal lobe is long and pointed, flanked by a pair of short, rounded lobes.

As restricted by Haug, "Prolecunites is confined to the uppermost Devonian and the Carboniferous. The type of the genus is Gomatites

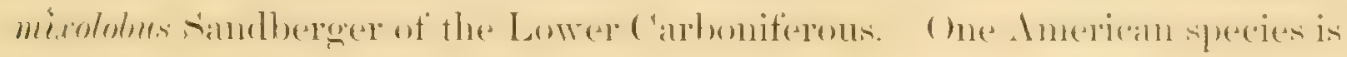
found in the Middle Coal Measures.

\footnotetext{
"Études sur les Goniatites, p. 50.

b Die Cephalopoden des Domanik im südlichen Timan, p. 45.

c Cephalop, der Mediterranen Triasprovinz, p. 199.

d Etudes sur les (ioniatites, p. 52.
} 


\section{Prolecanttes? compactus Meek and Worthen.}

Plate V, figs. 5-7.

1865. Goniatites compactus, Meek and Worthen, Yroc. Acad. Nat. Sci. Phila., 1865, p. $15 \pm$.

1573. Gromiatites compactus, Meek and Worthen, Geol. Surv. Illinois, Vol. V, p. 611, Pl. XXXI, tig. $2 \mathfrak{\imath}-\mathrm{c}$.

1897. Primoceran compactum, ,1. P. Smith, Proc. Cal. Acad. Sci., 3d series, Geology, Vol. I, No. 3, p. 118.

The systematic position of this species is somewhat doubtful; the septa are of the Prolecanites type, while the cross section of the whorl retains the Anarcestes shape, approaching that of Gastrioceras. It is evolute, with broad, slightly arched whorls, wide umbilicus, and rounded umbilical shoulder. It may be that this species should be made the type for a new

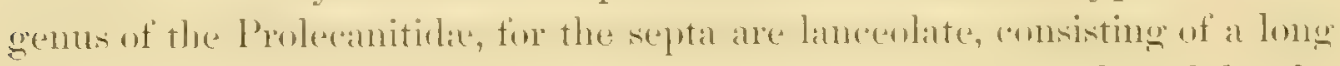
tongue-shaped ventral lobe, flanked by two similar laterals, while the saddles are broadly rounded; but the writer has not seen the original, and is of the opinion that no one has a right to found genera or species on illustrations alone, of the accuracy of which he has no knowledge. It is barely possible, but not at all likely, that in this case, as in that of Croniatites yreencastlensis, the impressions of the internal septa on the rentral of the next inner whorl give the lanceolate character to the lobes.

Occurrence and locality.-Middle Coal Measures, Menard and Macoupin counties, Ill.

\section{Prolechites greenil Miller. \\ Pl. VIII, figs. 4, 5a, 5b.}

1892. Gmiatites greenï, S. A. Miller, Adrance sheets Eighteenth Ann. Rept. Geol. Surr. Indiana, p. 76, Pl. X, figs. 5.6 .

1894. Goniatitew meenï, S. A. Miller, Eighteenth Ann. Rept. Geol. Surv. Indiana, 1. 330, Pl. X, tigs. 5,6 .

Shell minute, discoidal, evolute, volutions more than four in number, narow, and little embracing. Abdomen narrow and rounderl. Cross section of the whorl elliptical. Umbilicus wide and shallow. Septa close and lancenlate, consisting of a short, pointed, tomgure-shaped rentral lober

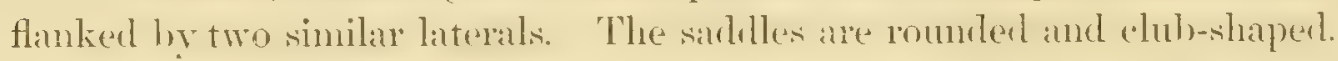
The shane and the septa resemble Profectuites lymi Meek amb Worthen, 
but in $P$. greenii, the ventral lobe is broader and dart-shaped, while in I'. lyoni it is simply a blunt point.

Occurrence-Lower Carboniferous, Kinderhook, New Albany, Ind.

Prolecantes gurleyi Smith, sp. nov.

Pl. XXIV, figs. 1-4.

Shell extremely evolute, laterally compressed, widely umbilicate. Whorls low, and increasing very slowly in height, little embracing, and scarcely indented hy the imerolutions. The unbiliens is wide and shallow. The eross section of the whorl is cluallate oval, the corve heing interrupted

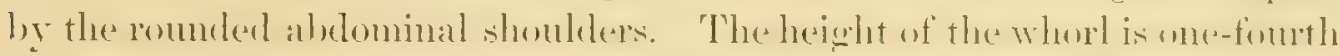

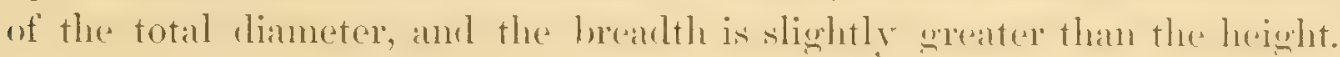
The width of the umbilicus is one-fourth of the total diameter of the shell. Six volutions are seen at the diameter of $16 \mathrm{~mm}$.

The surface of the cast is entirely smooth, none of the outer shell being preserved. The length of the body chamber is unknown, as the only specimen seen is septate to the end. 'The septa are spatulate, the ventral lobe is undivided and tongue-shaped; the first lateral lobe is similar, and of the same size; the second lateral is two-thirds of the length of the first, and similar in shape. There is a short auxiliary lobe on the umbilical slope.

This species is most nearly related to Prolecanites yreenii Miller, but differs from it in the greater evolution, wider umbilicus, less compressed whorls, and slower increase in size.

Occurrence-Lower Carboniferous, Kinderhook stage, Cedar Galp, Wright County, $H_{0}$. The type specimen, No. 8600, paleontologic collection, Walker Musem, University of Chicago, was loaned to the writer by Dr. Stuart Weller. 'The specific name is given in honor of Prof. W. F. E. Gurley.

\section{Prolecanites houghtoni Winchell.}

1562. Goniatites hengletoni, A. Wincheli, Am. Jour. Sci., 2d series, Vol. XXxIII. p. 363.

Shell discoidal, evolute; whorls but slightly anbrateing, with Hattenest venters and sides, and cross section elongate-oval. Umbilicus wide and

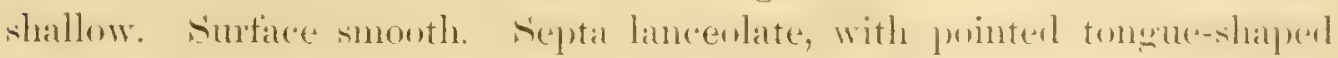
lobes and rombled sardles: an undivided ventral lober, two principal and an auxiliary lateral lobe. 
This species differs (according to Winchell) from I'. lyoni in the greater relative length of the second lateral lobe and the anxiliary saddle, and also in the greater compression of the cross section of the whorl; from $P$. henslowi Sowerby in the more acute lateral lobes and greater length of the saddles. Occurrence-Lower Carboniferous, Kinderlook stage, Marshall, Mich.

$$
\begin{aligned}
& \text { Prolecanitem ? Louthinensis Romley. } \\
& \text { Pl. VI, figs. 6-8. }
\end{aligned}
$$

1895. Gonintites louisianensis, R. R. Rowley, Am. Geologist, Vol. XVI, p. 221, Pl. XXXI, figss. 15-18.

This minute species is of somewhat doubtful systematic position. It is hardly possible to determine it from Rowley's figures, but the writer is indebted to Dr. Stuart Weller, of the University of Chicago, for the loan of several well-preserved specimens from the Gurley collection. On these the lanceolate type of lobes can be clearly seen, resembling the young stages of Pronorites cyclolobus, the so-called "Ibergiceras" stage.

The whorls are evolute, depressed, little embracing. The shell has one or two constrictions to a revolution. The general shape reminds one strongly of Anarcestes, but the septa show that the transition to the stock of the Prolecanitidx has already been made. The ventral lobe is long, tongue-shaped, and undivided; the lateral lobe is lanceolate, and the second lateral or auxiliary lobe is shallow, broad, and lies just outside of the umbilicus. The internal septa consist of a pointed antisiphonal lobe, flanked by a pair of shallow laterals. All the saddles are rounded.

Occurrence.Lower Carboniferous, Kinderhook stage. Louisiana, Mo.

The figured specimen is deposited in the paleontologic collection, Valker Museum, University of Chicago (Gurley collection).

\section{Prolecanties Lyoni Meek and Worthen.}

$$
\text { Pl. XVI, fig. 18; Pl. XIX, figs. 9-11. }
$$

1860. Goniatites lyoni, Mreek and Worthen, Proc. Acad. Nat. Sci. Phila., 1860, p. 471. 1860. Gomirtites hyus, J. Hall, Thirteenth Rept. N. Y. State Cab. Nat. Hist., p. 102, figs. $17,18$.

1866. Goniatites lyoni, Meek and Worthen, Geol. Surr. Illinois, Vol. I1, p. 165, Pl. XIV, figs. 11a-c. 
1879. Gomiatites lyomi, .J. Hall, Pal. N. Y., Vol. V, Pt. II, p. 476, II. LXXII, fig. 12: PI. LXXII, figs. :11; H, LXXIV, fig. 7.

1852. Mrolecumites lymi, E. von Mojsisovies, Cephalop. Meditermanen Triasprovinz, 1). 1999.

1555. Gomintites lyoni, C. L. Herrick, I3ull. Denison Univ., Vol. IV, 1’l. VII, fig. 2. 1895. Gomiutites lyomi, C. L. Herrick, Geol. Surr. Ohio. Vol. VII, I’l. XVIII, fig. 2. 1899. Prolecenites Tynni, F. Frech, Die Steinkohlenformation, 1'l. XLVI, L, fig. 11. 1901. Prolecrnites lyomi, F. Frech. Ueher devonische Ammoneen, p. 6t, fig. $21 \mathrm{c}$

Shell discoidal, compressed, evolute; whorls but little embracing, only about one-fifth of the inner volutions being covered by the outer ones. Whorls six or more in number, the inner ones being semielliptical in cross section and the outer ones trapezoidal, with flattened sides and abdomen and rounded shoulders. Breadth of the whorl is two thirds of the height. The whorls enlarge very slowly, giving a large number of whorls for a small diameter.

Length of body chamber unknowru, but fragments indicate that specimens have attained a diameter of $80 \mathrm{or} 90 \mathrm{~mm}$, exclusive of body chamber.

Surface of the shell unknown, but the cast is smooth and devoid of constrictions and all other surface onnamentation.

Septa lanceolate, with pointerl and slighty murounte lobes and romonded saddles. Ventral lobe undivided and shorter than the laterals, which are two in number; the dorsal (internal) lobes cousist of an undivided tongueshaped antisiphonal, with a short, blunt lobe on the umbilical margin. 'The total number of lobes is therefore one pair less than on most species of Prolecanites, but this difference has not been considered by any writers to be of generic value, since so many otherwise typical species of Prolecanites possess this number of lobes, and several even have one more pair than the normal.

Occurrence.-Irolecanites lyoni occurs in the Lower Carboniferous, Kinderhook stage, at Rockford, Ind., along with Aganides rotutorius de Koninck, Muensteroceras oweni Hall, M. parallehum Hall, Prodromites pramaturus Smith and Wellex, and $P$ 'gorbyi Miller. It has also been foumd in the same horizon in the Waverly group of Granville, Ohio.

\section{Prolecanites marshallensis Winchell.}

1862. Goniatites marshallensis, A. Winchell, Am. Joux. Sci., 2d series, Vol. XXXIII, p. 36 .

1865. Goniutites marshallensis, A. Winchell, Proc. Acad. Nat. Sei. Phila., 1865, p. 133. 1870. Goniutites marshallensis, 1. Winchell, Proc. Am. Philos, Soc., Vol, XI, p. 258. 
Shell evolute, discoidal, little embracing; cross section elliptical; impression moderate. Whorls at least four in number, with slow increase of growtl. Umbilicus wide. Surface smooth. Length of body chamber unknown.

Septa lanceolate and close together. Ventral lobe long, pointed, and narrow; first and second lateral lobes not so large as the ventral and not sharply terminated. Auxiliary lobe outside of the umbilical border short and blunt. Antisiphonal lobe deep.

The nearest American species is $P$. Tyoni Meek and Worthen, from

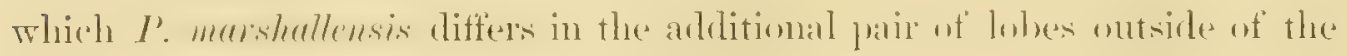
umbilical border and in the greater length of the rentral lobe. It is also somewhat more involute than $P$. lyoni. Winchell thought this species to be nearest akin to $P$. mixolobus Plillips, which was chosen by Mojsisovics as the type of Prolccanites, but the lobes of $P$. mixolobus are not mucronate but rather club-shaped, and the auxiliary lobe is nearly as large as the principal laterals, and the ventral lobe seems to be very small.

Occurrence.- $P$. marshallensis was found in the Lower Carboniferous Kinderhook stage, Marshall group, at Marshall, Moscow, Battle Creek, Napoleon Cut, Mich., and in the Warerly group at Weymouth and Newark, Ohio.

\section{Supertamily GLYPIIOCHRATIDA.}

This group was established by Hyatt ${ }^{a}$ to include a number of species from the Upper Devonian, Carboniferous, and Permian. 'The oldest genera are Aganides (Brancoceras) and Prionoceras, which began in the Upper Devonian and attained their acme in the Lower Carboniferous. Both genera are smooth-shelled, and hoth have a pointed, milivider, ventral lobe and two pairs of lateral lobes, of which the first is angular; the saddles of most species of both genera are broadly rounded, although on Prionoceras (Goniatites) belvaliamm de Koninck the first lateral saddles are angular. The only difference between the two genera is that Aganides is compressed, high-whorled, almost discoidal, and very involute; while Prionoceras is broad, low-whorled, and evolute. Hyatt considered Brancoceras as the radicle of the Glyphioceratidx, and traced the group from Anarcestes of the Lower Devonian, through Tomoceras (P'arodoceras) of the 
Middle Deronian. He admitted the near relationship between the two

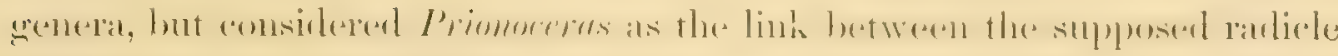
Brancoceras and Glyphioccras. 'The genealogy of the Glyphioceratida, according to Hyatt, is as follows:

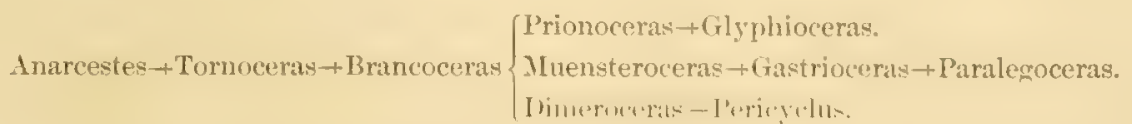

Prof. K. A. von Zittel has recently merged Prionoceras in Brancoceras, not even giving subgeneric rank to the former. But even though they may be nearly related, their phylogeny justifies the separation. Both genera probably branched off about the same time from Parodoceras or from Sporaloceras in the Upper Devonian, but Aganides (Brancoceras) is not the radicle, at least of the main branch of the Glyphioceratida. While it is possible, although not known, that Wuensterocerus may go through a Bramcoceras stage, P'rionoceras does not, neither does Glyphioceras, nor Goniatites s. str. Prionoceras seems to have come directly from P'trodoceras, and in turn gave rise to Glyphioceras. It seems likely, too, that some species of Gastrioceras descended directly from Prionoceras by division of the ventral. lobe, while other's may have come from Glyphioceras. In any case, whether it came off from the radicle, or through Glyphlioceras, Gastrioceras is a later

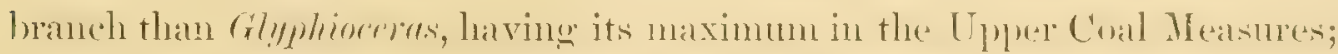
it therefore deserves to rank as an independent genus. It also seems proper

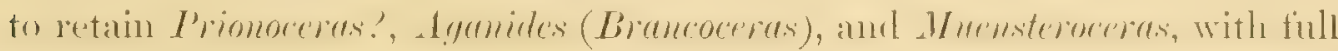
generic rank.

Frech $^{b}$ derives the Glyphioceratidxe from Sporadoceras, but this hyputhesis is not in hammen with the ontogeny of comintes and cilmphioceras. However, too little is known of the development of these forms to warrant any positive statement.

Some members, at least, of this group are prosiphonate, and deserve the designation "ammonite" as much as Lobites of the Trias, for simplicity of the septa is no longer considered as a distinctive mark of the goniatites. Hyatt considered the Glyphioceratide as a family, but E. Inug ${ }^{\circ}$ is of the opinion that it is rathere a gromp of morpholegieal expivalents than a

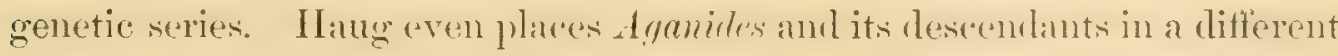


phylum or superfanily, and derives them from a different Devonian grenus, Tornoceras. This seems to the writer to be going further than the facts warmant. But it is beyond doubt that the Glyphioceratida, as Hyatt used the term, can be divided into two series. The writer prefers to retain the two under the same phylum or superfanily, Glyphioceratide, and to name each of the component series or families after the most characteristic gentus.

Under the Glyphioceratidae s. str. would fall I'rionoceras?, P'ericyches, Glyphioceras, Goniatites, Gastrioceres, Paraleyoceras, Schistoceres.

Under the Aganididne would fall Aganides, Muensteroceras, Goniolohoceras, Dimorphoceras, Hilleroceras.

From the Glyphioceratide it appears that the Arcestida and the Tropitida have been derived. The Ptychitidae sech to have sprung from the Aganidida.

\section{F'anily GLYPHOCERA'TIDAs s. str. \\ Genus Prionoceras? Hyatt.}

This genus was established by $\mathrm{Hy}_{\text {yatt }}{ }^{a}$ to include rather evolute, lowwhorled forms, with undivided external lobes; and angular lobes and saddles. The type chosen was Goniutites divisus IIuenster of the I)evonian. Another species assigned to the grenus is Coniatites belvatianus de Koninck from the Lower Carboniferous. It is very doubtful if either species fits the description. Certainly neither has angular saddles, and even the external lobe of Goniatites belvaliams is divided at maturity.

As a consequence of this the genus has been either abandoned entirely or merged by most authors with Aganides (Brancoceras). Whether this be correct or not, the ontogeny of later forms teaches that such a genus was the radicle of the greater part of the Glyphioceratidx. It is very doubtful whether Prionoceras is represented in America at all, but three species are doubtfully assigned to it. Frech ${ }^{b}$ has shown that Gomiatites divisus, the type of I'rionoceras, is identical with Goniatites sulcatus Muenster and G. linearis IIuenster, both listed by Hyatt as most characteristic members of Brancoceras (Aganides). A strict ruling would thus throw this genus out entirely, although Haug proposes to retain it on account of its supposedly longer body chamber. 


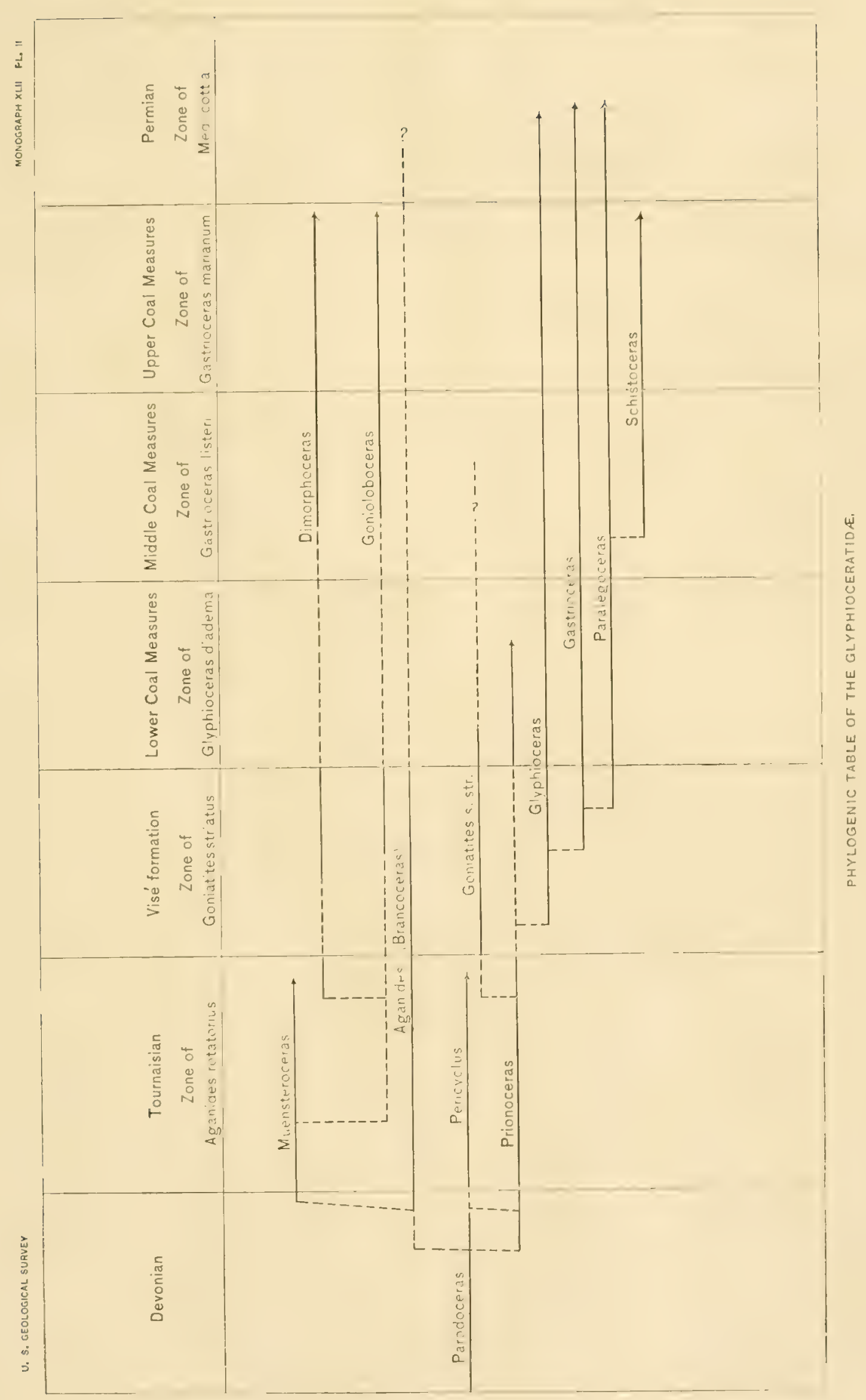





\section{Prionoceras? andrEwsi Winchell.}

1570. Goniatites andmexi, A. Winchell, P'roc. Am. Philos. Soc., Vol. XI. p. 259.

Shell subglobose, evolute; whorls broader than high, low-arched, helmet-shaped, greatest width close to rmbilical shoulder. Umbilicus deep and wide, umbilical shoulders abrupt and bearing faint ribs. Surface ormamented with four constrictions to a revolution.

Septa consisting of a long, undivided, tongue-shaped, pointed ventral lobe, a similar but shorter and broader lateral lobe, a rather narow clubshaped external saddle, and a broad oblique lateral.

Occurrence-Lower Carboniferons, Kinderhook stage, Lower Waverly group, Newark, Ohio.

Prionoceras? mbownense Miller.

I'I. I, figs. 1 and '2.

1891. Goniatites brownensis, S. A. Miller, Advance sheets Seventeenth Ann. Rept. Geol. Surv. Indiana, p. 90, Pl. XVIII, figs. 3, t.

1892. Goniatites brownensis, S. A. Miller, Seventeenth Ann. Rept. Geol. Surv. Indiana, p. 700, Pl. XVIII, figis. 3,4 .

Shell globose, evolute, broadly rounded on the venter, and rather

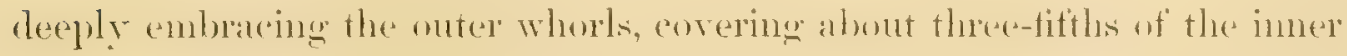
ones. Umbilicus rather wide, being about two-fifths of the total diameter of the shell, and exposing all the inner whorls. Surface of the shell apparently smooth.

Septa not distinctly made out, but consisting of a pointed rentral lobe, with a pair of angular laterals, and probably also with a pair of auxiliary lobes on the umbilical shoulders. The dorsal lobes correspond to the external, as well as conld be seen on the broken face of the whorl.

Occurrence.-Lower Carboniferous, Kinderhook stage, Kuobstone grouip, Brown County, Ind.

\section{Prionoceras? ohionnse Winchell.}

1870. Goniatites ohioensis, A. Winchell, Proc. Am. Philos. Soc, Vol, XI, p. 259.

Shell subglobose, umbilicated; whorl depressed, helmet-shaped, abdomen broadly arched, sides sloping steeply to the abrupt umbilicus, which has diameter of more than one-half of the diameter of the shell.

Septa consisting of a slender rentral lobe with rounded end, a first 
lateral lobe, twice as longe as the rentral, clavate and pointed, and a short triangular auxiliary lobe on the umbilical shoulder. The external saddle is long and broadly rounded, the lateral saddle is narrower and shorter.

This species is said to be most nearly related to "Goniatites" allei Winrhell, but differs in its shorter and rounded ventral lobe, its lomger lateral, and in porsessing the anxiliary lobe; also its sides are less convex, and the umbilicus less abrupt than in G. allei.

Occurrence.-Lower Carboniferous, Kinderhook stage, Lower Waverly group, Newark, Ohio.

\section{Genus Pericrclus Mojsisovirs.}

Goniatites minceps de Koninck was chosen by E. von Mojsisovies as the type of the genus Pericyclus, characterized by its angular lobes, spatulate saddles, and coarse ribs crossing the abdomen. Hyatt ${ }^{a}$ included this

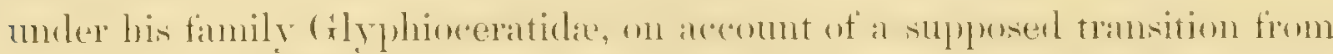
Brancoceras to Pericyclus. In a later paper Hyatt ${ }^{b}$ places Pericyche in a new fimily, Periegelidte, supposed to differ from the alyphioneratida in the possession of two internal lateral lobes instead of one on each side. This was based on Haug's mistaken copy of the septa of Pericychs liochi Holzapfel, ${ }^{c}$ in which there seem to be two internal laterals. A figure of the septa of this species is given by Holzapfel, ${ }^{a}$ showing but one internal lateral lobe on each side. 'There can, therefore, be no reason for separating this genus from the Glyphioceratidie.

\section{Pertcyclus blatri Miller and Gurley.}

I'l. XYI, fign. $4,5$.

1896. Goniatites blairi, Miller and Gurley, Bull. Illinois State MIts. Nat. Hist. No. 11, p. 35, Pl. IV, tigs. 4, 5 .

Shell discoidal, moderately evolute, becoming more so with age; whorls compresised, with romberl venter and thattened sides, with subanguiar umbilical shomlders. Cmbilicus narrow in youth, hut widening lapidly with age as the spiral opens out, on account of the fact that the whorl increases very slowly in height. Ifeight of whorl slightly greater thatu its

a Proc. Boston Soc. Nat. Hist, Vol. XXII, p. 330.

$\imath$ Cephalopoda, p. 551, in Eastman's Transl. Zittel's Elements of Palrontology, 1900.

c Études sur les Goniatites, p. 27, fig. 6c.

a Pal. Abhandl., Vol. V, Pl. III, fig. 6. 
greatest breadth, which is just aluse the umbilical shoulders. The surface

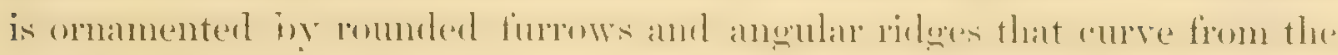

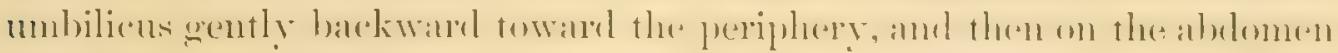

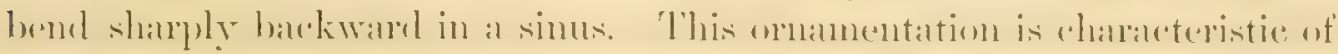

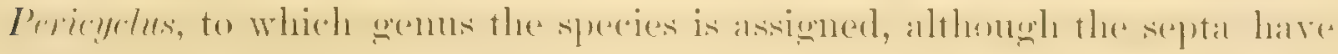
not been seen. It is more evolute and less robust than P. princeps, but is more nearly related to that than to any other known species. 'The strong transverse ribs crossing the abdomen without interuption are not known on any other genus of goniatites, and much reliance is placed in this character, even in the absence of knowledge of the septa.

Occurrence.-Lower Carboniferous, Kinderhook stage, Sedalia, Mo.

Pericyclus ? princeps de Koninck.

1843. Goniatites princeps, L. G. de Koninck, in d'Omulius, Précis élém. géol., p. 515. 18+2-184t. Ammonites princeps, L. G. de Koninck, Deser, anim. foss., p. 579, Pl. II, tign. $\because$, :

1850. Aganides princeps, A. d'Orbigny, Prod. de paléont. stratigr., Vol. I, p. 116. 1852. Ammonites princeps, C. G. Giebel, Fauna der Vorrwelt, Vol. III, p. $64 t$.

1550. Gomiatites princeps, L. G. de Koninek, Faune calc. carbon. de la Belgique, Vol. I, p. 268, Pl. XLIX, tigs. 1, 2.

1882. Pericyclus princeps, E. von Mojsisovies, Cephalop. Mediterranen Triasprovinz, P. 141.

1584. Pericych princeps, A. Hyatt, Proc. Boston Soc. Nat. Hist., Vol. XXII, p. 330. 18ss. Goniatites princeps, R. Etheridge, British Fossils, Vol. I, Palreozoic, p. 312.

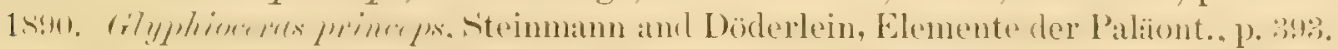
1897. Pericyctus princeps, Foord and Crick, Catal. Foss. Ceph. Brit. Mus., Pt. III, p. 145 , tigs. $68 \mathrm{a}$ and $\mathrm{b}$.

J. J. Bigsby ${ }^{a}$ cites Goniatites princeps from the Goniatite limestone of Rockford, Ind., but nu Americin collection is known to have an anthentive specimen of this, nor is it cited in any list of American species. In the paleontologic collection of the Malker Musemm, Univernity of ('hilangen, is a specimen wrongly labeled "Goniatites princeps," and this may have been the cause of the mistaken reference. Bigsby's citation is, therefore, probably a mistake. But it is by no means improbable that $P$. princeps may be found in the Kinderhook of America, since P. blairi, a closely related

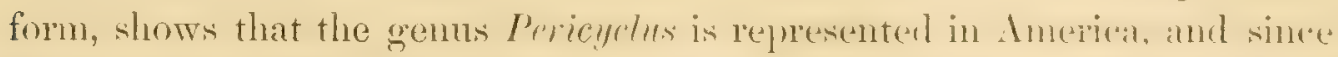
thes rest of the Kinderhook fauma so closely resembles that of Ireland and Belgium. 


\section{Genus Guyphioceras Hyatt (emend. Haug).}

In establishing his genus Glyphioceras Hyatt took for the type Goniatites spharicus Martin, already chosen by de Haan as the type of Goniatites, so that the group of G. splecricus and G. striatus can not properly come under this genus. But Hyatt divided his genus into two divisions, the second of which is characterized by open umbilici, less involution, broader and lower whorls, semilunular or trapezoidal cross section, fine lateral or umbilical ribs. Of the species mentioned by Hyatt under this section Goniatites diadema Goldfuss is the best known. E. Haug " has accordingly proposed to retain Il yatt's mance for this sex tion, and hats selected G. diadema as the type, although the first species mentioned by Hyatt is G. obtusus Phillips, which belongs to the group of G. striatus.

This division seems quite satisfactory from the stratigraphic standpoint, for Goniatites s. str. is almost confined to the Visé horizon of the

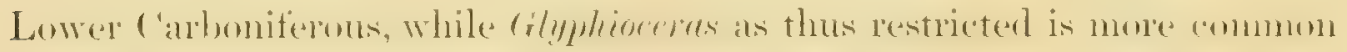
in the Lower Coal Meastures.

\section{Glyphioceras calyx Phillips. HI. XVIII.}

1836. Gomiutites calyx, J. Phillips, Geol. Yorkshire, Pt. II, p. 236, Pl. XX, figs. 2.2., ․․‥

1836. Goniatites mutabilin (pairs), J. Phillips, Geol. Yorkshire, Pt. II, p. 236, Pl. $\mathrm{XX}$, figs. $24,25(\operatorname{not} 26)$.

1852. Ammonites resicu (pars), C. G. Giebel, Fauna der Vorwelt, Vol. III, p. 470.

1880. Goniatitex caly,x, L. G. de Koninck, Faune calc. carbon. de la Belgique, Vol. I, p. 265, Pl. L, fig. 18.

188t. Ifomnceras calyx, A. Hyatt, Proc. Boston Soc. Nat. Hist., Vol. XXII, p. 330. 1888. Gonintites colyx, R. Etheridge, British Fossils, Vol. I, Palrozoic, p. 311. 18s9. Glyphincercas mutabile (pars), E. Holzapfel, Pal. Abhandl., Vol. V, p. 30. 1897. Glyphioceres calyx, Foord and Criek, Catal. Foss. Ceph. Brit. Mus., Pt. IIl, p. 206.

1898. Glyphioceres calyx, E. Haug, Études sur les Goniatites, p. 101.

This species was selected by Hyatt as the type of a new genus Homoceras, but its characters are common to the young of all members of Cilyphioceres when they have just made the transition from the Prionoceres stage of grow th. Iolzalptel theoght this was the young of (r. mutabile Plillips, as, indeed, it may be, but the commection has not yet been demonstrated.

The shell is much smaller than is usual with the Glyphioceratidx, not 
reaching a greater diameter than $6 \mathrm{~mm}$; it is evolute, has wide open umbilicus, low flattened whorls with trapezoidal cross section, faint umbilical ribs which reach almost to the abdomen. There are abont three rather faint constrictions to a revolution. 'The surface is ormamenterl only with fine smooth cross strix. 'The septa are like those figured by de Koninck; the differentiation into two extemal lobes las not taken place, as in the rest of the section Glyphioceras, but it is indicated by the incipient ventral saddle. 'lhese are certainly persistent larval characters, and the so-called species may be merely a case of arested development such as is seen in the young of Glyphioceras diadema, but whether it is really the young of some other species, or whether it is a separate form, can lardly be detemined as yet. It any rate the adult of Glyphioceras mutrbile has not been found in America, and the American form can hardly be the young of that species. Nor in the beds where it occurred have any other species with similar young

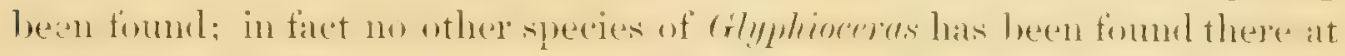
all. To the writer it seems quite possible that $G$. calyx is only the male of

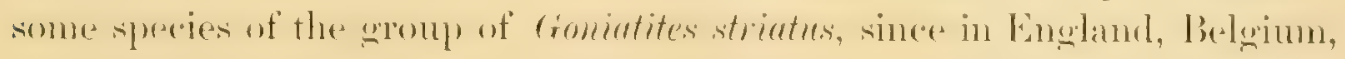
and America it is associated with this group, and more especially because the young stages are exactly alike in these. A demonstration of this is at present impossible, for we know nothing of sexual variations in the ammonoids.

Occurrence.-The specimens figmed here are deposited in the geologic

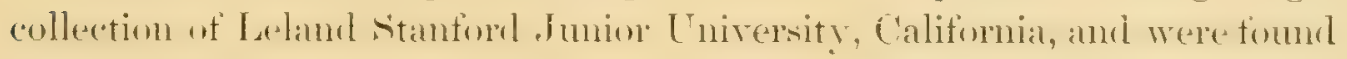
in the Lower Carboniferous, St. Louis-Chester stage, Fayetteville shale,

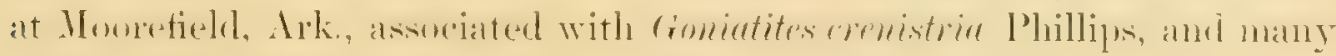
other species of invertebrates characteristic of this horizon. In Emope the species is found in the Visé horizon, in England, Belgium, and Germany.

\section{? Glyphioceras diadema Golifuss.}

Pl. XII, fig. 10.

1597. Ammonites diadema (Goldfuss), H. E. Beyrich, De Goniatitis, p. 15, Pl. II, figs. $8-10$.

1537. Ammomites listeri, H. E. Beyrich, Beitr. 7. Kennt. Rhein. Uebergangsegeb, p. 14, P. II, figs. 6a-b, and 11 .

1542-14. Ammonites diademu, L. G. de Koninck, Descr. anim. foss., p. 574. Pl. L, figs. $1 \mathrm{a}-\mathrm{f}, 2 \mathrm{a}-\mathrm{b}$.

18t5. Goniatites dirulema, Murchison, Verneuil and Keyserling, Créol. Russie d'Europe, ete., Vol. II, p. $36 \%$, Pl. XXVII, figs. la-d. 
1S51. Goniutites diadema, G. Sandberger, Jahrbuch. Nassau Ver. Nat., Vol. VII, 2 and 3, p. 30t, PI. III, tig. 33.

1855. Aqanides diartema, F. McCoy, Brit. Pal. Fossils, p. 563.

!1863. Gomintites tiadema, F. Roemer, Zeitschr. Deutsch. Geol. Gesell., Vol. XV.

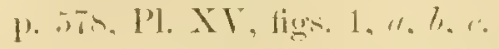

1850. Goniatites diadema, WV. Branco, Paleontographica, Vol. XXVII, PI. IV, fig. 1. 1854. Glyphioceras diadema, A. Hyatt, Proc. Boston Soc. Nat. Hist., Vol. XXII, p. 329. 1888. Ammonites dirdema, E. Beyrich, Zcitschr. Deutsch. Geol. Gesell., Vol. XXXVI, p. 213.

15ss. Goniatites diadent, R. Etheridge, British Fossils, Vol. I, Palaozoic, p. 311. 1889. Gastrioceras diadema, E. Holzapfel, Pal. Ahhandl., Vol. V. Pt. I, p. 26.

1897. Glyphioceres diademe, Foord and Crick, Catal. Foss. Ceph. Brit. Mus., Pt. III, p. 202 , fig. 98.

1898. Gluphiocerces stridatum (pars), E. Haug, Études sur les Goniatites, p. 92.

In England, Belgium, and Germany this species is characteristic of the Lower Coal Measures; in Arctic America it has been found on Bergo Island, "brought in by the Nares expedition.

It is quite likely that Phillips's name, G. striolatum, will take precedence over G. diadema, which Goldfuss left in manuscript, and which Beyrich afterwards published.

A similar species has been described by $\mathrm{F}$. Roemer under the name Gomiatites listri Mantin, from Carboniferous limestone of sumatra, although this latter may be Goniatites beyrichianm de Koninck. At any rate this type of Glyphioceras is widespread, characteristic of Lower Coal Measures, and may be chosen as a zone fossil. It has not yet been found within the United States, but may well be expected there on account of general similarity of faunas of this horizon.

\section{Gliphioceras? Hathawayanum McChesney.}

1860. Goniatites huthremana, .J. H. McChesney, Descr. New Pal. Foss., p. 60.

1865. Goniatites hathareyuna, J. H. McChesney, Illustrations of new sp. Pal. Foss., Pl. III, fig. 3.

1868. Goniutites hathurouyanu, J. H. McChesney, Trans. Chicago A cud. Sci., Vol. I. p. 53, Pl. III, tig. 3.

'The following description is quoted from McChesne $y^{-5}$ last paper:

Shell moderately small, discoidal, much compressed. Volutions two to three, strongly embracing, and concealing about two-thirds of the inner rolutions; umbilicus comparatively wide and shallow. Dorsum [renter] extremely narrow, having a linear depression along its center; sides of the volutions very slightly and regularly 
convex to the slope into the umbilicus, which is more shaply curved. Aperture very narrow and much elongated. Sejuta on the sides of the volutions strongly sige moidal, with the curves or lobes which stand back toward the apex much more sharply turned than those pointing in the opposite direction. Outer shell entirely wanting in the specinen.

MeChesney's drawing and description do not permit a certain determination as to whether this species is a Glyphioceres or a Crastrioceres.

Occurrence. - Michdle Coal Measures, Lasalle, Ill.

Glyphoceras? ueviculum Ililler and Faber.

P. VIII, figs. 10, 11.

1892. Cromiatites leviculus, Miller and Faber, Jour. Cincinnati Soc, Nat. Hist., Vol. XIV, p. 167, Pl. VI, figs. 10, 11.

Shell discoidal, whorl highly areherl with gently romided sides and highly arched narow abdomen. Umbilical shonders abrupt. Whorls deeply embracing, the outer whorl being indented to about one-third of its height by the next inner volution. Width of whorl is more than threefourths of its height. Umbilicus wide and deep, width is one-third of the total diameter. On the imer whorls the umbilicus is proportionally narrower, and the breadth of the whorl greater than its height.

Surface of shell smooth, no constrictions or ribs having been seen. Specimens septate throughout, thus the body chamber and aperture are unknown.

Septa close together and sinuous, as is usual in the Glyphioceratidx. The rentral lobe is divided by a small pointed siphonal satdle; the lateral lobe is fumel-shaped and pointed; the external and the lateral sardlles are broally romorled. There are three internal lobes as in all typual Glyphioceratida, but their shape could not be ascertained.

Occurrence-Lower Carboniferous, St. Louis stage, Crab Orchard, Ky. The type is depositerl in the paleontologic collection, Walker IItsemm, University of Chicago.

\section{Glyphioceras pygmeun Winchell.}

1862. Goniatites mgman, A. Winchell, Am. Jour. Sci., थd series, Vol. XXX11, p. 366.

Shell globose, involute, umbilicus small. Whorl broad, depressed, breath equal to one-half of the total diameter. Surface with four constrictions to a revolution.

MON xidI-1) - : 
Septa consisting of a broad, obtusely rounded ventral lobe, with a very small siphonal indentation; lateral lobe shallow, acute, fumnel-shaped; ventral and lateral saddles broad, shallow, with circular ends.

Winchell compares this species with Glyphiomeres striolatum Phillips, from which it differs in the smaller umbilicus, larger ventral lobe, and rentral saddles. The description, however, would make it appear that this species in nearer to Glyphioceras mutabile Phillips.

(cerurence.-Supposed to have come from the Lower Carboniferous (?), Kinderhook stage, Marshall group, Battle Creek (?), Mich.

\section{Genus Goniatites de Haan.}

When Hyatt undertook a revision of the goniatites in his Genera of Fossil Cephalopods he did not include comiutite's itself in his list, but included the trpe of all this stock in his new genus Glyphioceras. Miny years before this de Haan " had described and figured the genus foniutites,

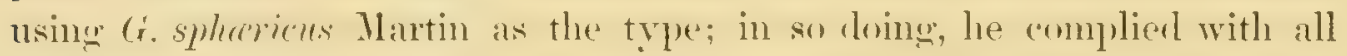
the laws of nomenclature, and mo genus stands on a firmer basis than this. Therefore when it has been found that de Itam includerl under this name many species of diverse orgin, it is quite proper to give sepalate generic titles to these; but the type of the original genus can not receive any new name, and must always stand for the original species and all like it.

Il yatt" first mentions fromiatites splacericus under the description cilyphioceves, and therefore this species is to be regarded as the trpe of the gemus, rather than G. crenistria, which authors usually cite as the type. Hyatt divides the genus Glyphioceras into two sections:

I. Involute ghobose shells, including sueh forms as Goniatites sphericus Martin, G. crenistria Phillips, and G. striatus Sowerby.

II. Forms with compresised whorls, and npen umbilici, including Comiat tites obtusus I'hillips as type of the section, Cr. diudema Croldfuss, Cr. platylolues Phillips, G. barbotanus II. V. K., and others. Of this second section, $G$.

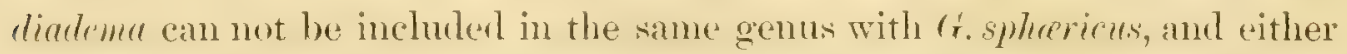
a new name will have to be given it or else Hyatt's name will have to be restricted to this section. E. Haug " lmoposes to restrict the name Goniatites

"Mon. Ammon. et Gron., 1825, \%. 159.

b Proc, Boston Soc. Nat. Hist., Vol. XXII, p. 328.

c Études sur les Goniatites, p. 26. 
to species of the type of $G$. sphcricus, G. crenistria, and $G$. striatus; and to restrict Glyphioceras to the type of G. diadema.

As thus restricted, Goniatites is almost entirely confined to the Lower Carboniferous zone of croniatites striatus, and is thus of great importance in stratigraphic paleontology. It has been shown by researches in the ontogeny of Goniatite's crenistria and Gilyphioreras diadema" that these two genera have a common origin in I'rimoreras, which is considered hy most paleon-

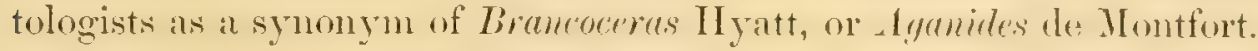

F. Frech ${ }^{c}$ thinks that Goniatites s. str. was derived from Sporadoceras; and certainly S. mammilliferum Sandherger and st. subinvolutum ILuenster, as figured by Frech, do resemble rosely what the writer has described as the Irionoceras stage of growth in comiatites. It is, however, by no means certain that these species should be assigned to sporaloceras, als II yalt took Cromiatites mammillifer as the type of his genus Dimeroreve, and regarded it as transitional from Brancoceras to I'ericyclus. But if these species should be acrepted as genuine members of sporadoceras, the writer agrees with Frech in regarling this genus as the ancestral stock of the Glyphioceratidie s. str.

\section{Goniatites choctawensis Shumard.}

1868. Goniatites choctawensis, B. F. Shumard, Trans. St. Louis Acad. Sci., Vol. II, p. 109.

The following description is quoted from Shumard's paper:

Shell discoidal, broadly and strongly rounded on the dorsum [abdomen] and flattened laterally, inner volutions entirely concealed by the outer one; umbilicus small, its diameter scarcely equal to one-sixth the breadth of the volution; transwerse diameter of volution about equal to the breadth from dorsal to ventral side; alperture lunate, much wider than high; surface marked with fine distinct revolring lines, less than the width of the intervals between, crossed by extremely fine, crowded, transverse strix. Septre having but one lateral lobe on either side; dorsal [rentral] lobe as wide as long, divided into two laneeolate luranches hy an acersisory saddle, which is truncated and bifid at tip and extends almost to the middle of the lohe; dorsal [ventral] saddle of the same form, but wider and double the length of the branches of the dorsal [ventral] lobe; superior lateral lobe wider than the dorsal [ventral] saddle, and contracted at extremity to an acute point.

This shell resembles the $G$. striatus (Sowerby) both in the form and number of the lobes of the septre and its surface markings, and for several years I have had

a J. P. Smith, Proc. Cal. Acad. Sei., 3d series, Geology, Vol. I, No. 3, pp. 105, 128.

6 W. Branco, Palæontographica, Vol. XIVII, PI. IV, figs. 1 a-o.

e Ueber devonische Ammoneen, ‥ 84. 
it in my cabinet under the latter name. A closer examination, however, shows points of difference which appear to me to be of specific value. The stria of our shell are finer and more crowded; the dorsum [abdomen] is more broadly rounded. and the umbilicus is proportionally smaller.

This description shows the species to belong to the group of $G$. striatus, and the differences noted are precisely those characteristic of Gr. crenistria, which has been found in both Arkansas and 'Texas, and of which Goniatites choctavensis may turn out to be a synonym.

Occurrence-Lower Carboniferous, St. Louis-Chester stage (?), Bend formation, Choctaw Nation (?), Ind. 'T'

\section{Goniatites crenistria Phillips.}

Pl. X, figs. 12-16; Pl. XIV; Pl. XV; Pl. XVI, figs. 1a-j; Pl. XXVI, figs. 1-5.

1836. Gomiatites crenistria, J. Phillips, Geol. Yorkshire, Pt. II, p. 234, Pl. XIX, figs. $7-9$.

1541. Goniatites crenistria, J. Phillips, Pal. Foss. Cornwall, Devon, and IV. Somerset, p. 121, Pl. L, tigs. $23+a-g$.

1843. Goniatites crenistria, F. A. Roemer, Verstein. Harzgeb., 1) 33, II. IX. figs. 10a-b.

1850. Goniatites crenistria, F. A. Roemer, Palrontographica, Vol. III, p. 51, PI. VIII, figs. $13 a-c$.

1852. Gomiatite crenistria, F. A. Roemer, Palrontographica, Vol. III, p. 93, 1'l. XIII, figs. $29 a-c$.

1852. Aganides spherious var crenistria, F. McCoy, Brit. Pal. Fossils, p. 567.

1870. Goniatites spharions (not Martin), F. Roemer, Geol. Oherschlesien, p. 55, Pl. VI, figs. 2a-b.

1880. Goniatites striatus (pars), L. G. de Koninck, Faune eale. carbon. de la Belgique, Vol. I, p. 253.

1882. Goniatites crenistria, C. Barrois, Mém. Soc. Géol. du Nord, Vol. II, No. 1, p. 292, Pl. XIV, fig. 1.

1884. Glyphioceras crenistria, A. Hyatt, Proc. Boston Soc. Nat. Hist., Vol. XXII, p. 329.

1893. Glyphioceras incisum, A. Hyatt, Fourth Ann. Rept. Geol. Surv. Texas, p. 4 ir. Pl. XLVII, figs. $41 \pm 8$.

1897. Glyphioceras crenistria, Foord and Crick, Catal. Foss. Ceph. Brit. Mus., Pt. 111 , p. 160, fig. 76.

1897. Glyphioceras incisum, J. P. Smith, Proc. Cal. Acad. Sci., 3d series, Geology, Vol. I, No. 3, p. 111, Pls. XIII-XV.

1598. Goniatites crenistria, E. Haug, Etudes sur les Goniatites, p. 27.

1898. Glyphioceras crenistria, G. C. Crick, Trans. Limn. Soc. Zool., 2d series, Vol. VII, P't. IV, p. 106, Pl. XX, figs. 15-1s.

This specoies has been united by many paleontologists with comiatites

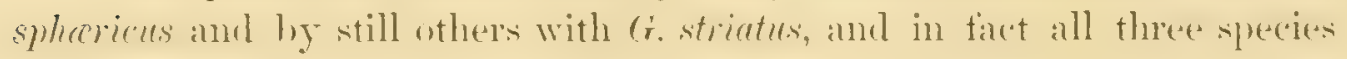


have so much in common that it is very hard to distinguish them; it is quite possible that they are only varieties of $G$. splucricus.

The form is glolesse, broad, low-whorled, with semilumular cross sertion. 'The mubilieus is very narrow, about ane-tenth of the diametere of the shell, so that the immer coils are concealed. 'There are four or five constrictions to a revolution, visible both on the shell and the cast. The whorl is exceedingly involute, ateh whorl being indented to allont three-fifths of its height hy the preceding. The shell is marked with distinct cons stria with fine, shatre erenulations, which show only towarl maturity. 'The derations between the pits of the crenulations become in the arlut indistinct spiral striations, giving a finely reticulate aspeet to the surfice. 'These are not visible on the cast. In the adult stage the cross stria bundle near the umbilicus, forming weak incipient nodes.

From G. spharicus this species is distinguished by being more compressed laterally, lesis globose, having narrower umbilicus, weaker spiral strial, and coarsere cross striae. From G. striatues this species mat be distinguished chiefly by its slightly narrower unbilicus, its tiner spiral striar, and coarser cross strix. 'The table below, compiled from Foord and Crick's catalogue, shows the principal differences and agreements between the three species:

\begin{tabular}{|c|c|c|c|}
\hline & (r. crcnistria. & G. striatus. & G. sphtricus. \\
\hline Breadth in proportion to diameter .. & $\mathrm{B}=\frac{3}{5} \mathrm{D} \ldots \ldots \ldots$ & $B=50 \ldots \ldots \ldots$ & $B={ }_{4}^{3} \mathrm{D}$. \\
\hline Height of whorl to width.......... & $\begin{array}{l}\text { A little wider than } \\
\text { high. }\end{array}$ & Wider than high... & IV. \\
\hline Height of whorl to diameter........ & A little over $\frac{1}{2}$ D ... & $\frac{3}{7} \mathrm{D} \ldots$ & $\frac{1}{1 j} \mathrm{D}$ \\
\hline WVidth of umbilicus to diameter..... & $\mathrm{U}=\mathrm{T}_{\mathrm{I} 0}^{1} \mathrm{D} \ldots \ldots \ldots$ & $\mathrm{U}=\frac{1}{6} \mathrm{D} \ldots \ldots \ldots \ldots$ & $\mathrm{U}=\frac{1}{5} \mathrm{D}$ \\
\hline $\begin{array}{l}\text { Indentation of last whorl by preced- } \\
\text { ing. }\end{array}$ & $\begin{array}{l}\text { Indented more } \\
\text { than } \frac{1}{3} \text {. }\end{array}$ & Nearly & More than $\frac{1}{2}$ \\
\hline Constrictions to revolution . ......... & $\begin{array}{l}( \pm \text { in American } \\
\text { spécimens.) }\end{array}$ & \pm to 5 feeble........ & 4 or more faint. \\
\hline Septa to revolution... & $19-20 \ldots \ldots \ldots$ & $20 \ldots \ldots \ldots$ & 18. \\
\hline Spiral strice.......... & $\begin{array}{l}\text { (Fine in American } \\
\text { specimens.) }\end{array}$ & Strong and sharp... & Very fine. \\
\hline Cross strix .. & Finely crenulated . - & $\begin{array}{l}\text { Sharply incised, } \\
\text { sinuous. }\end{array}$ & Obscure. \\
\hline
\end{tabular}

Not enough specimens have been studied to show that these characters are really constant; that they are not constant is shown by the fact that 
Mecoy grouperl all three under G. spllariens, and de Koninck united $G$ r. crenistria with $G$. striatus.

Occurrence-Goniatites crenistria is common in the upper part of the Lower Carboniferous in Great Britain, Belgimm, and Germany. It lats been described under the name of Cilyphioceras incisum Hyatt from the st. Louis-Chester stage, of Texas (see Pl. X, figs. 12-16) and Arkansas, associaterl with cromiatites striatus (E Cilyphoreras cumminsi Hyatt (in the Bend formation of 'Texas, and the Spring Creek limestone, so-called Fayetteville shale, of Arkansas.

The specimens figured on Pl. XIV; Pl. XV; Pl. XVI, figs. 1a-j; and Pl. XXVI, figs. 1-3, came from Moorefield, Arkansas, from calcareous nodules in shales. They were associated with an undoubted St. Louis fauna. The specimen figured on Pl. XXVI, fig. 5, came from the same formation, near Boles, Ark.

On account of the great interest and importance of this species, there is given below the complete ontogeny of the American comiutites remistria

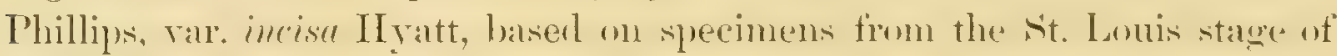
Moorefield, Ark., associated with. an undoubted St. Louis fauna. 'The development of this species was first published by the writer in a paper in the Proceedings of the California Academy of Sciences, ${ }^{a}$ from which paper the following description with some modifications is taken:

\section{IAAVAI, NTAGES.}

In order to obtain the larval stages of Goniatites crenistria, a number of adults were selected, so as to make sure of the identity, and the outer coils were broken off until the desired size was obtained. This necessitated the destruction of several specimens, but was well worth while in view of reliability of the results. The specimens were studied in three different mountings, dry on cardboard, in a drop of water on cardboard, and in water in a watch glass orer a strong condensing lens. In the first way the surface markings are seen best, in the second the sutures and form, in the third the internal structure when the specimen is translucent. 'The nomenclature used is that of Hyatt, published in Phylogeny of an Acquired Characteristic.

Phylembryonic.-The protoconch represents the first shell secreted by the shell gland, and must have been formed while the animal was in the egg. It is quite possible that some of the chambers were formed before the egg was hatched, but this can not be determined on fossils. The protoconch is taken for convenience to represent the phylembryonic stage of growth, the end of the embryonic, when the class or phylum can be determined and the animal is already a cephalopod. In shape 
the protoconch is a smooth, rather chongate, bohbin-shaped, oral body, of which the upper part projects forward in a lap, where the first chamber was joined to it. The protoconch was not the whole of the embryo chamber, for a part of the spiral tube must have furnished a lodging for the embryo; but after the formation of the first air chamber it is no longer posible to dotemine how long the primitive hody ahanber was. The protoconch corresponds to the primitive nautilian shell from which the ammonoids descended, but the parallelism is not exact. for the initial chamber of the natiloids is not calcareous, while anderation of development has pushed hatek to the embryo the calcareous shell of the ammonoids.

In the protoconch is seen the beginning of the syphon, or syphonal crecum, a pear-shaped knob, projecting a short distance into the embryonic shell. It must have been present in the embryo, for it is older than the first suture, but its function is unknown. In some specimens what seemed to be a tube could be seen attached to the coreum; this is probahly the prosiphon described hy Munier-Chalmas, but no specimens sufficiently definite to figure could be obtained.

On PI. XIV, figs. 1 and 2, ${ }^{a}$ is shown the protoconch from which all the chambers have been broken off.

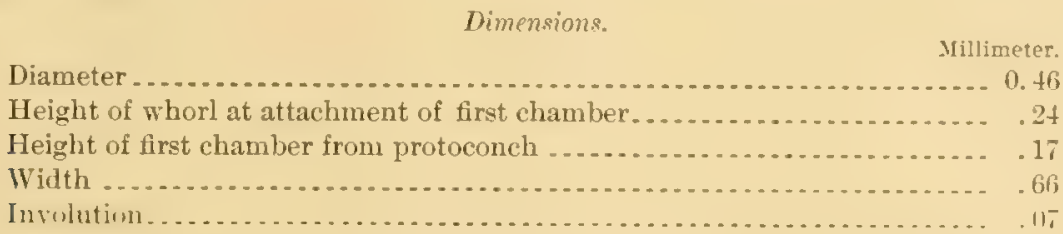

The protoconch is constant in size and dimensions, for several specimens were obtained free from the air chambers. Also a number of others were broken back almost to the protoconch, and the dimensions agreed, as nearly as could he determined.

On Pl. XIV, figs. $3, t$, and 5 , is shown the protoconch of a Goniatites from the Carboniferous of Scott County, Ark., 2 N., 29 W., sec. 36, near the center. This species was comprared by the writer to tr. spluevions Martin, and said to be identical with the species from Moorefield. But although the adults are nearly alike, the protoconchs are quite unlike, as may be seen by a comparison of the tro figures.

Dimensions of the Scott County form.

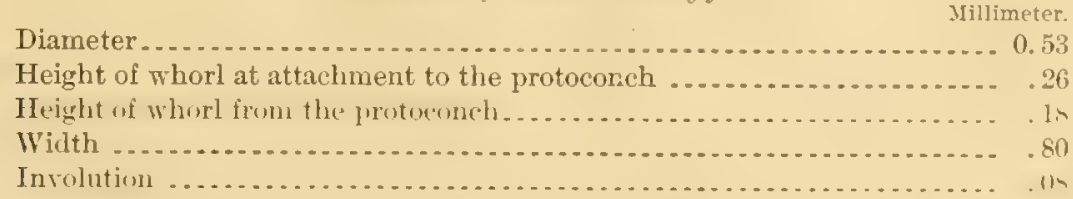

These figures show it to be larger and proportionally broader than the trpical $G$. crenistria. It the species are identical, then this is an unusual rariation.

Ananenionic. - As soon as the first air chamber is formed the animal has left the embryonic and begun the larval staces and then takes rank with the chambered nautiloids. The suture at this stage consists of a very broad rentral saddle, with a pair of narrow, lateral lobes. On PI. XIV, fig. 1, is shown this suture; fig. 6

a The figures here referred to are those of this monograph.

$b$ Proc. Am. Philos. Soc., Vol. IXXY, p.11. 
shows this, and also the second chamber wall; figs. 9 and 10 show the ananepionic suture with half a coil attached. Pl. XVI, fig. 1, shows the initial suture along with the later ones. While this stage can not be compared to any particular genus, it corresponds to some natilian form of the Silurian. The ananepionic siphon is about halfway between the dorsum and the renter; in this character, too, agreeing with the nautiloicls. Whore the siphon pasies through the partition the wall is bent backward in a cone and has a siphonal collar around the tube. The surface is still smooth, no ornamentation of any sort ever having been seen on early stages of ammonoids.

Metanepinnic.-With the second larral substage the shell becomes a true ammonoid. This begins with the second suture, which takes on the ventral lobe of the goniatites. The shell is smooth, as before, and the whorl changes little in shape, being still low, broad, and little embracing. The sutures and shape correspond exactly to Ancrostes, the primitive goniatite and radicle of the ammonoids. Anar-

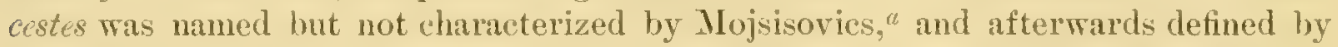
Hyatt, ${ }^{b}$ as containing forms with smooth, broad, and low whorls, with semilunular cross section, deep umbilicus, and rather broad abdomen. Goniatites subrautilinus Schlotheim, of the Middle Deronian, was chosen as type of the genus, but most of the species occur in the Lower Devonian, in the Hercynian bects, which were formerly assigned to the Upper Silurian:

Goniatites cremistrie shows the Anarcestes stage at the second and third sutures, and resembles closely 1 . luteseptutus Beyrich of the Lower Devonian. On Pl. XIV, fig. 6 , is seen the transition from the ana- to the meta-nepionic; figs. 9 and 10 show the transition from ananepionic (first suture) to metanepionic (second and third sutures); figs. 11 and 12 show the duarcestes stige at the first and second sutures visible on the whorl. The metanepionic sutures, seen in projection on Pl. XVI, figs. $1 \mathrm{~b}$ and c, consist of a deep, rounded, rentral lobe, and a pair of broad, shallow, latera! lobes. When the animal has progressed thus far in its development it is a true goniatite, and the siphon has already turned to the outside of the whorl, or abdonen.

Puranepionic. - When the broad lateral lobes become indented with a pair of lateral saddles, the sutures, the narrow umbilicus, and the broad, low whorl all correspond to Parodocerrs Hyatt, of the Middle and Upper Devonian. G. crenixtriu reaches this stage at the fourth suture, at a diameter of about $0.68 \mathrm{~mm}$., one-third of a whorl, and continues in it for the fourth, fifth, and sixth sutures, up to a diameter of $0.80 \mathrm{~mm}$., and five-eighths of a whorl. Pl. XIV, figs. 9 and 10 , shows the form at the Purudoceras stage, at one-half a whorl, with the following dimensions:

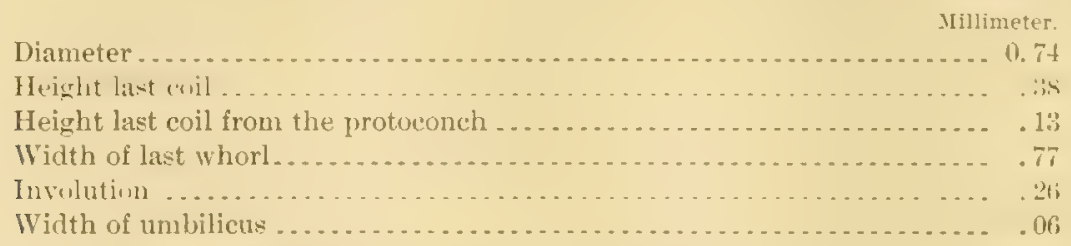

"Cephalop. Mediterranen Triasprovinz, p. 181.

b Proc. Boston Soc. Nat. Hist., Vol. XXII, p. 309. 
On Pl. XIV, figs. 11 and 12, the I'eroulocemestage shows at the fourth, fifth, and sixth sutures.

Teanic.-When the ammonoid in its growth no longer shows the characters of its distinct ancestors, but has already taken on those of its own family, it may be said to have left the larval stage proper and to have hegun its youth. 'The ananeanic is then the beginnimg of the adolesent period. Gr. cremistriv at the seventh suture, three-fourths of a whorl, and diameter of $0.85 \mathrm{~mm}$., changes its form markedly; the two pairs of lateral lobes become more pronounced, and the ventral lobe becomes smaller in proportion; the coil leaves its clove spiral and shows decided egression, the umbilicus becomes wider, while the chamber becomes actually narrower than in the Purolocerts stage, as seen from these figures: Width of chamber at diameter $0.7 t \mathrm{~mm}$. is $0.77 \mathrm{~mm}$., at diameter $0.92 \mathrm{~mm}$. it is $0.69 \mathrm{~mm}$. The inrolution also becomes less. At diameter $0.90 \mathrm{~mm}$. and end of the first whorl a decided constriction, marking a temporary mouth of the shell, makes its appearance. This stage corresponds to the Upper Devonian and Carboniferous genus I'ronoceres Hyatt, of which I'. Aivisum Muenster, of the Upper Devonian, and I'. betruliumum de Koninck, of the Lower Carboniferous, are the types. These species have broad, Iow, rather evolute whorls, with wide umbilici and smooth surfaces, ornamented only with periodic constrictions. The external sutures consist of an undivided, pointed, rentral lobe, one pair of angular lateral lobes, and a second pair of rounded lobes on the umbilical border. 'The external saddles are angular and the lateral saddles rounded and broad. If the genus Promoceras is dropped, as now seens likely, it will be necessary to give some other name to this stage of growth. The beginning of the Prionocerces stage is shown on Pl. XIV, figs. 11 and 12 , in the widening of the umbilicus, egression of the spiral, and narrowing of the chamber.

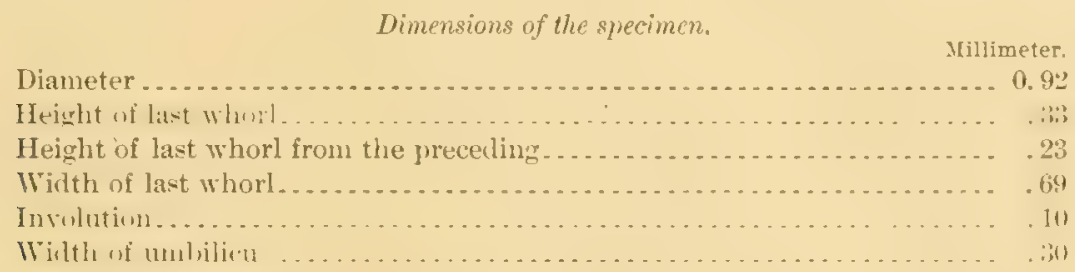

This stage begins at $0.85 \mathrm{~mm}$. diameter, three-fourths of a whorl from the protoconch, and lasts with little change except increase in size for two revolutions up to a diameter of $2.25 \mathrm{~mm}$., when the transition to Goniatites begins.

Plate XV, figs. 1 and 2, shows a continuation of the P'rionoceres stage, at 1 I whorls.

\section{Dimensions.}

Millimeters.

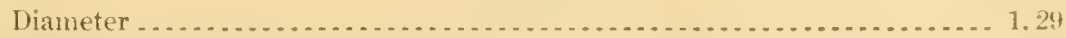

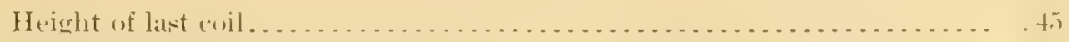

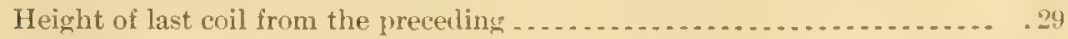

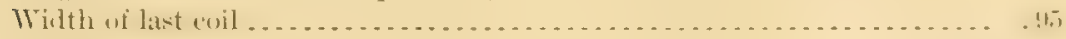

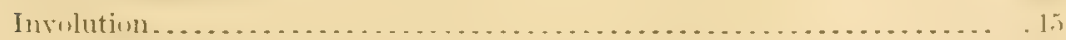

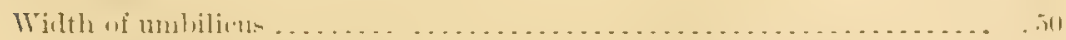

"Proc. Boston Soc. Nat. Hist., Vol. XXII, p. 328. 
On this specimen are seen two constrictions about two-thirds of a revolution apart, thus making the resemblance to Primucens very striking. At this stage are first seen the cross striz of growth. A continuation of the same generic stage is shown on Pl. XV, figs. 3 and 4 , at $1 \frac{\pi}{8}$ whorls.

Dimensions.

Millimeters.

Diameter. 1.38

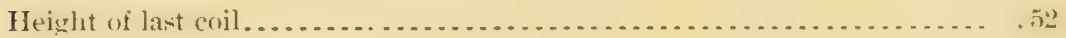

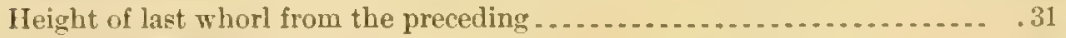

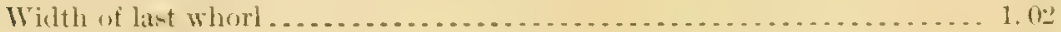

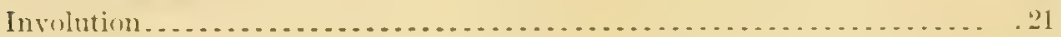

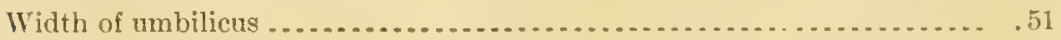

The relative dimensions are nearly the same as at diameters $0.92 \mathrm{~mm}$, and 1.29 mm., but the utures difler slightly, the rentral lobe being slightly hlunted, as shown on Pl. XVI, fig. 1. On this specimen only one constriction was risible at diameter of $0.85 \mathrm{~mm}$.

On Pl. XV, figs. 5 and 6 show a larger specimen still in the Prionoceras stage, at $2 \frac{1}{5}$ whorls.

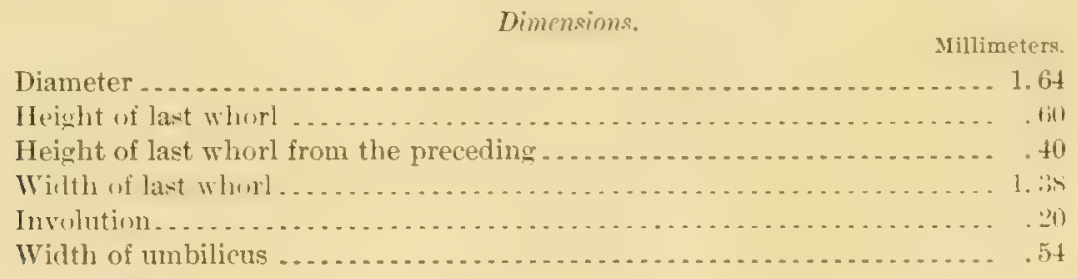

No constrictions were visible on this specimen; that one which occurs at end of the first whorl being concealed by the outer coil. The relative dimensions are nearly the same as on the preceding specimens, except that the last whorl is proportionally broader and the umbilicus nurrower. The sutures are the same as on the last specimen. The end of the Priunoceras stage is shown on Pl. XV, tigs. $T$ and $\mathrm{S}$, at $2 \frac{3}{4}$ of a whorl.

Dimensions.

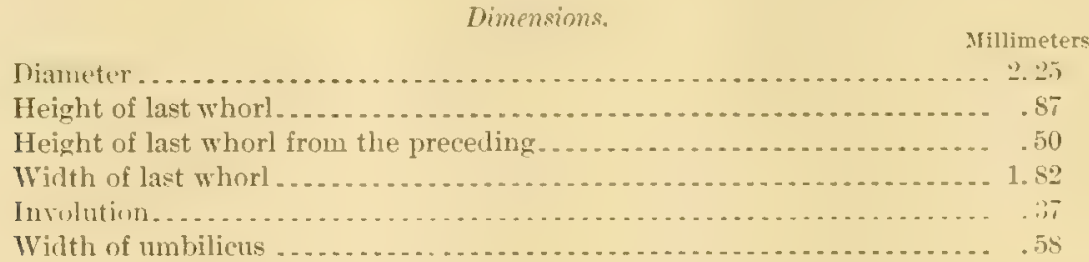

No constrictions were visible on this specimen, the earlier ones being concealed by the outer whorl. The figures show that the relative dimensions remain nearly as before, but the umbilicus becomes considerably narrower. 'The sutures are like those of the smaller specimens, but on the last half whorl the ventral lobe becomes rery much flattened, and at diameter of $2.2 \mathrm{~mm}$. becomes slightly indented by the beginning of a ventral saddle, thus showing a transition to Goniatites and the end of the adolescent stage. To youthful stages larger than this were suc- 
cessfully broken out in condition to figure. but the imperfect ones ohtained showed a gradual narrowing of the umbilicus and increase in height of the whorl and involution.

\section{ADULT STAGF.}

The form of the adult $G$. crenistric has already been sufticiently described in this paper and in Hyatt's monograph. 'The sutures changed in increasing depth of the rentral sinus and sharpening of the lateral lohes, as shown on Pl. XVI, fig. 1. taken from a specimen of diameter of $15 \mathrm{~mm}$. The early alult sutures hare been figured by Hyatt, ${ }^{a}$ and the figures are reproduced in this paper.

Pl. XV, fig. 9, shows a small specimen in the early adult stage; it agrees in all essentials with those of larger growth, only the rentral saddle is shorter and the lateral saddles more rounded.

Taule of stages of grouth.

\begin{tabular}{|c|c|c|c|c|c|c|}
\hline - & Protoconch. & $\begin{array}{l}\text { Protoconch } \\
\text { and two } \\
\text { chambers. }\end{array}$ & $\begin{array}{l}\text { One-half } \\
\text { whorl, } \\
\text { Anarrestes to } \\
\text { Parmoceras. }\end{array}$ & $\begin{array}{c}\text { First whorl, } \\
\text { Parodoeras } \\
\text { to } \\
\text { Prionmeras. }\end{array}$ & $\begin{array}{l}\text { Prionocers } \\
\text { stuge. } \\
\text { 1) whorls. }\end{array}$ & $\begin{array}{l}\text { Prionoceras, } \\
1 \% \text { whorls. }\end{array}$ \\
\hline & $m m$. & $1 \mathrm{~mm}$. & $m m$. & $m m$ & $m m$ & $m m$. \\
\hline Diameter ..... & $0.46=1.00$ & $0.61=1.00$ & $0.7 t=1.00$ & $0.92=1.00$ & $1.29=1.00$ & $1.38=1.00$ \\
\hline Ileight of last whorl. & $.24-.52$ & $.31=.50$ & $.3 \varsigma=.52$ & $.33=.35$ & $.45=.34$ & $.52-.39$ \\
\hline \multicolumn{7}{|l|}{ Height of last whorl } \\
\hline from the preceding .. & $.17=.36$ & $.15=.2 t$ & $.13=.17$ & $.23=.25$ & $.29=.22$ & $.31=.22$ \\
\hline Width of last whorl... & $.66=1.56$ & $.66=1.08$ & $.7=1.04$ & $.69=.75$ & $.95=.73$ & $1.02=.73$ \\
\hline Involution ... & $.07=.15$ & $.16=.26$ & $.26=.35$ & $.10=.10$ & $.15=.11$ & $.21=.15$ \\
\hline Width of umbilic & & & $.06=.08$ & $.28=.30$ & $.50=.38$ & $.51=.37$ \\
\hline \multirow[t]{2}{*}{ - } & & & & & & \\
\hline & $\begin{array}{l}\text { Hionvecras, } \\
2 ! \text { whorls. }\end{array}$ & $\begin{array}{l}\text { Prionoceras, } \\
2 f \text { whorls. }\end{array}$ & $\begin{array}{c}\text { Prionoceras to } \\
\text { Goniatiles. }\end{array}$ & $\begin{array}{l}\text { Prionoceras to } \\
\text { Gonintites. } \\
\text { End of } \\
\text { neanic. }\end{array}$ & $\begin{array}{l}\text { Goniatites. } \\
\text { Anephebic. }\end{array}$ & Gmiatites \\
\hline Diamete & $\begin{array}{l}m m . \\
1.6 t=1.00\end{array}$ & $\begin{array}{l}m m . \\
2.25\end{array}$ & $\begin{array}{l}m m . \\
2.60=\end{array}$ & $\begin{array}{l}m m . \\
3.00=1.00\end{array}$ & $\begin{array}{l}m m . \\
6.00=\end{array}$ & $m m$ \\
\hline Height of last whorl & $.60=.36$ & $.8 \mathrm{r}=.3 \mathrm{~s}$ & $1.24=.47$ & $1.45=.48$ & $3.50=.58$ & $5.50=.50$ \\
\hline \multicolumn{7}{|l|}{ Height of last whorl } \\
\hline from the preceding .. & $.40=.23$ & $.50=.22$ & $.76=.29$ & $.83=.27$ & $1.80=.30$ & $3.00=.27$ \\
\hline Wilth of last whorl.... & $1.3 s=.8 t$ & $1.82=.80$ & $2.30=.83$ & $2.62=.94$ & $(i).(x)=1.00)$ & $10.010-.411$ \\
\hline Involution ...... & $.20=.12$ & $.37=.16$ & $.48=.18$ & $.62=.20$ & $1.6 \overline{3}=.27$ & $2.50=.22$ \\
\hline Width of umbilicus .... & $.54=.32$ & $.58=.25$ & $.61=.23$ & $.66=.22$ & $.90=.15$ & $1.00=.09$ \\
\hline
\end{tabular}

\section{SUMMARY.}

The ontogeny of Gomiatites is of interest not only for its own sake, but also because it is the most important genus of the largest family of ammonoids of the Carboniferous, and because this family gave rise to a large part of the ammonites of the Trias. Goniatites in its ontogeny goes through the following stages: phylembryonic, protoconch, representing the primitive cephalopod; ananepionic, Silurian 
nututiloid; metanepionic, Anarcestes of Lower Devonian; paranepionic, Purodoceras of Middle Devonian; neanic, Prionoceres of Upper Deronian and Carboniferous, showing gradual transition through ana-, meta-, and paraneanic, and a gradual change from Prionoceras to Goniatites in the late adolescent and early adult stages. Prionocerces or some similar form seems to have been the family radicle, and Aganifles is a side branch, since Gomiatites does not go through any stage corresponding to the latter genus. Gustriocerus comes from P'rionoceras (through Glyphinceress) by somewhat narrowing the whorl and division of the ventral lobe. Glyphioceres and Goniutites come directly from I'rionocerts by narrowing the umbilicus so as to conceal most of the inner whorls, and by division of the rentral lobe.

The division of the family Glyphioceratide into Aganides, Prionoceras, Gonioloboceras, Dimorphoceras, Pericychu, Gomiatites, Glyphioceras, Hünsteroceras, Gastriocerces, Peralegoceras, and Schistoceres is quite proper for phylogenetic reasons.

According to Steinmann the Ceratitida of the Trias are descended from Gustriocerce, and the Tropitide from Pericyclus, but neither of these groups goes through stages of growth corresponding to these genera. Tropites does, however, go through a P'ionoceras stage, and later it resembles closely Gustrincerus, but it already has the Tropites keel before the ventral lobe is divided. But it is quite likely that some of the genera assigned to the Tropitida do descend directly from other nember's of the Glyphioceratide.

All specimens of Goniutites crenistria figured in this paper, except those on Pl. X, figs. 12-16, are deposited in the greologic collection of Leland Stanford Junion Lniversity, Californial, and "ame from the St. Lonis-(Gester stage (Fayetteville shale), of Moorefield, Ark. 'Those figured on PI. X, figs. 12-16, are from the Lower Carboniferous, St. Louis-Chester, Bend formation, near Richland Springs, San Saba County, Tex.

\section{Goniatites (iReencastlensis ililler and Gurley.}

$$
\text { Pl. XVII, figs. 12-14. }
$$

1596. Goniatites yrencustlensis, Miller and Gurley, Bull. Illinois State Mus. Nat. Hist. No. 11, p. 4t, pl. 5, figs. 12-14.

This species has been referred by E. Haug ${ }^{a}$ to Coniatites s. str., on the supposition that the pointed undivided abdominal lobe was merely the lobe of the internal part of the next outer coil pressed on the shell. 'Through the kindness of Dr. Stuart Weller the writer was allowed to examine the type of this species in the palentolegie collection, Waller Musemm, Lniversity of Chicago, and found the facts to be as Haug suspected. This specimen is, therefore, a member of Goniatites s. str., and not of Prianoceras, as one would think from the drawing published.

Occurrence-Lower Carboniferous, St. Louis stage, Greencastle, Ind. 
Gontatites kentuckiessis diller.

Pl. XVII, fig. 1.

1589. Gomintites Rentuctiensis, S. A. Miller, North American Geol, and Pal., p. ttu. fig. 740 .

1896. Gomintites lientuckiensis, Niller and Gurley, Bull. Illinois State Mus. Nat. Hist. No. 11. p. 40, Pl. V, tig. 1.

This species is probably identical with G. striatus Sowerby, and thus with Glyphioceras cumminsi II yatt, for the globose rather flattened form, the size of the umbilicus, the septa and the spiral ridges all agree with that species. But Miller does not describe nor figure any constrictions on the shell, although it probably has them in the earlier stages.

Occurrence.-Lower Carboniferous, St. Louis stage, Crab Orchard, Ky. The type is depositer in the paleontologic collection, Walker Museun, University of Chicago.

Goniatites lunatus Hiller and Gurley.

Pl. VI, figs. 2-5.

1896. Goniatites lunatus, Miller and Gurley, Bull. Illinois State Mus. Nat. Hist. No. 11, p. 41, Pl. V, tigss. $2-5$.

shell globuse, volutions enlarering rapidly, and becoming mole broadly rounded with increasing size. Cross section of the whorl semilunular. Greatent breath of whorl about one-fourth laroer than the lexight, and situated at a point about one-fifth of the height of the whorl above the umbilicus. Whorls detply embracing, the last whorl being indented to one-halt of its height by the preceding one. Lmbilicus rery namow, heing not more than one-eighth of the total diameter. Surface of the shell smootle except for fine cross imbricating stria of growth. No constrictions have been observed.

Septa ronsisting of a narrow divided rentral lobe and broad, shatlow, bluntly pointed laterals. External saddles bather narrow, lateral sardlles broad and shallow. Dorsal septa unknown.

In this species is seen the survival of a type that prevailed in the St. Louis-Chester stage of the Lowere Carboniferous, hut it has applarently lonst the constrictions and tendeney to surface ornamentation chamateristic of the group at that time.

Occurrence-Coal Measures (Middle?), Elkhorn Creek, Kentucky. 
Deposited in the paleontologic collection in Walker Museum, University of Chicason. 'The writer's thanks are due Dr. Stuart Weller for the use of the drawings of this species, from Bull. No. 11, Illinois State Mus. Nat. Hist., Pl. V, figs. 2-5.

\section{Goniatites newsomi Smith, sp. nov. \\ Pl. XVII, figs. 2-5.}

Whorl depressed, with broably rounded abdoment, and angular umbilieal shoulders. Whorl a little wider than high, erreatest breadth a little above the middle, indented to half its height by the preceding whorl. Involute, umbilicus rather wide, about one-fourth of diameter of shell; narrower in young. Several sharply incised constrictions to a revolution showing on both shell and cast. These bend sharply forward on the abdomen, making a broad sabdle, with a narrower lobe. Shell ornanented with strong spiral striae or ridges, with hroader interspaces coarser than on G. striatus. There are also fine cross strix of growth, giving a slightly reticulated aspect to the shell and the cast. These show on both shell and cast. The ornanentation resembles G. striatus, but is coarser, and the form is somewhat more strongly compressed than that species, from which it also differs in the form of the constrictions and in its wider umbilicus.

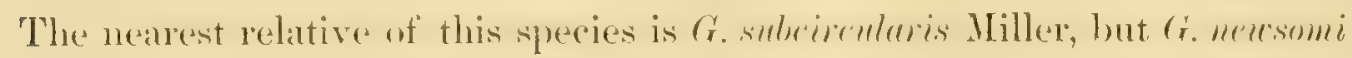
is much broader than $G$. subcircularis, has coarser spiral ridges, and wider umbilicus. The septa are more larval in character than those of G. striatus. Named in honor of the collector, J. F. Newsom. Deposited in the geologic collection of Leland Stanford Junior University, California.

Occurrence-Lower Carboniferous, St. Louis stage, so-called Fayetteville shale, Batesville, Independence County, Ark.

\section{Goniatites SPHericus Martin.}

1809. Conchyliolithus Nutilites sphericus, W. Martin, Petrif. Derb., p. 15, PI. VII, figs. $3,4,5$.

1814. Ammonites sphrericus, J. Sowerby, Min. Conchol., Vol. I, p. 116, Pl. LIII, fig. 2. 1825. Gomiatites sphericus, G. de Haan, Mon. Ammon. et Gon., p. 159.

1825. Orbulita sphxrica, J. Fleming, Hist. Brit. Anim., p. 248.

1832. Anmonites carbonarius (pars), L. von Buch., Phys. Abhandl. Berlin Akad. der Wissenschaften for 1830 , p. 176, Pl. II, figs. 9, 9 I, 9 II, 9 II (not fig. 9 IV). 1836. Goniatites spharicus, J. Phillips, Geol. Torkshire, Pt. II, p. 234, PI. XIX, figs. $t 6$. 
1837. Ammonites spherricus, L. Beyrich, De Goniatitis in Mont. Rhen., p. 13.

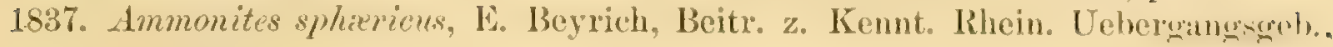
p. 38.

1842-4. Ammonites sphirricus, L. G. de Koninck, Deser, anim. foss., p. 570, PI.

XLIX, figs. 6; Pl. L, figs. 9, 10.

18tt. Goniatites spharicus, F. McCoy, Synop. Carb. Foss. Ireland, p. 15.

18t6. Goniatites sphericus, F. A. Quenstedt, Petrifact. Deutschl., Vol. I, Cephalopoden, p. 66, PI. TIL, fig. 11 (not fig. $10 \mathrm{a}-\mathrm{d}$ ).

1850. Aganides spharicus (pars), A. d'Orbigny, Prod. de Palént., Vol. I, p. 115.

1855. Aganides spherious, F. MeCoy, Brit. Pal. Fossils, p. 566.

1867. Goniatites sphrericus, H. Trautschold, Bull. Soc. Impér. Nat. Moscou, Vol. XL, No. 3, p. H, Pl. V, fig. 10.

1875. Goniatites sphericus, W. H. Baily, Charact. Fossils, p. 117, Pl. XL, figs. 9a, b. 1880. Goniatites sphrieus (pars), L. G. de Koninck, Faune calc. carbon. de la Belgique, Vol. I, p. 249, PI. XLVII, figs. 3-5.

185t. Glyphioceres splexricum, A. Hyatt, Proc. Boston Soc. Nat. Mist, Vol. XXII, p. 329.

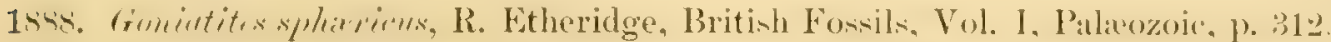
1897. Glyphioceras sphericum, Foord and Crick, Catal. Foss. Ceph. Brit. Mus., Pt. III, p. 157, fig. 73.

18:17. Glyphioceras spharricum, S. Weller, Trans. N. Y. Acad. Sci., Vol. XVI, p. 271, Yl. XXI, figs. 1, 2.

1598. Goniatites sphrenicus, E. Haug, Etudes sur les Goniatites, p. 26.

1901. Glyphioceras spharicum, F. Frech, Ueber devonische Ammoneen, p. 84, fig. $37 \mathrm{~b}$ and $\mathrm{c}$.

This species was somewhat doubtfully identifiod by Weller from the so-called Batesville samrlstone, St. Lonis-Chester stage, Lower carboniferous, of Batesville, Ark. Since the same group has furmished in that region $G$. crenistria and $G$. striatus the occurrence of $G$. spharicus is not at all unlikely, but better specimens must be found before the islontitication will be certain. 'The European form was the one chosen by IIyatt as the type of his genus Glyphioceras.

For the distinctions between Goniatites crenistria, G. sphrricus, and $G$. striatus see the descriptions of $G$. crenistria and $G$. striatus, where the relations of all three are fully discussed and the compurative dimensions griven. The three specoses have usually been confused, amd imbled they are separated by rery slight differences, which seem, however, to he fairly comstant. But it is by no means imposible, nor even molikely, that at leatst G. crenistriu and (r.striahes may be the same species, and botl posibly only a variety of $G$. sphericus.

Occurrence-Lumer Cabboniferous, St. Louis-Chester stage, liatesville sandstone, Batesville, Ark. 


\section{Goniatites striatus Sowerby. \\ P1. X, figs. 1-11; Pl. XXVI, figs. 6-13.}

131t. Lmmonites striatus. J. Sowerby, Min. Conchol., Vol. I, 1). 115, Pl. LIII, fig. 1. 1825. Gomiatites striatus, G. de Haan, Mon. Ammon. et Gon., 1) 15\%.

1836. Gmintitesstriutus, J. Phillips, Geol. Yorkshire, Pt. II, p. 2939, P1. XIX, figs. 1-3. 15t2-154t. Ammonites striutus (jars), L. G. de Koninck, Descr. anim. foss., p. כ̌6. Pl. XLIX, figs. 7, il, b, c, d; Pl. L, tigs. 7 , a, b. c.

1814. Gomintites strutus, F. MeCoy, Synop). Carb. Foss. Ireland, p. 16. 1852-185t. Gomitites sphixpicus (jars), F. Roemer, in Lethar Geognostica, 3d ed.,

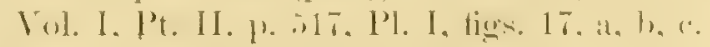

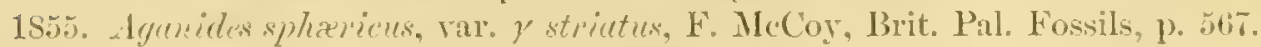

1876. Grmintites spharicu, F. Roemer, Lethar Geognostica, P't. II, Lethar Palaozoic'a, Pl. XLVI, tios. 11, a, b, c.

1880. Gromiutites striatus (pars), L. G. de Koninck, Faune calc. carbon. de la Belgique. Vol. 1, 1). 2533, I'. XLVI, figs. 1, 1a, 2, 2a; P. XLVII, figs. 1, 1a, 2, 2a.

185t. Glyphioceres striatum, A. Hyatt, Hroc. Boston Soc. Nat. Hist., Vol. XXIl, 1). 329.

189:3. Glyphinceras cumminsi, A. Hyatt, Fourth Ann. Rept. Geol. Surr. Texas, p. 467. [1. XLVII, figs. 33-13.

1897. Cryphioenes striatum, Foord and Crick, Catal. Foss. Ceph. Brit. Mus., Pt. III, P. 166 , fig. 75 .

18us. Gomiatites striatus, E. Haug, Etudes sur les Goniatites, p. 2S.

1899. Glyphiocenes strintum, F. Frech, Die Steinkohlenformation, Pl. XLVI,A figs. 1-2.

Shell globose, involute, with slightly flattened sides, and broadly rounded abdomen. Height of whorl about the same as the breadth, and a little more than one-half of the diameter. Whorl indented more than halt its height by the preceding whorl. Cimbilicus numw, about one-eighth of the dianeter, broader than in G. crenistria, and narrower than in $G_{0}$ sphericus. Three to four distinct constrictions to a revolution; these form a broad, shallow saddle on the abdomen, showing on both shell and cast.

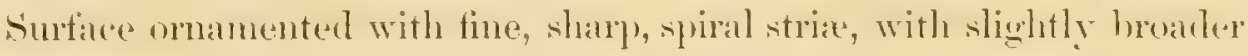
interspaces, and fine cross strix, giving a reticulated aspect to the shell. The cross strixe are finely crenulated, as in G. crenistria, but the spiral ridges much stronger. G. strintus is most nearly allied to G. crenistria, from which it differs in heing shightly more compressed, in its coarser spiral strix and less distinct. cross strixe, and somewhat wide umbilicus. From G. sphericus this species differs in its more distinct spiral and cross stria, the slight reticulation of the shell, the somewhat narower umbilicus, and the greater lateral compression. 


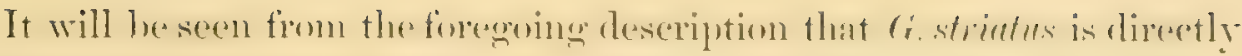

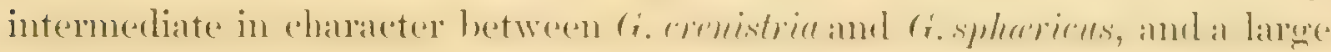
suite of specimens of all three would probably show transitions from one to the other:

There seem to be among the American specimens two rather wellmarkerl varieties of this species, one with the spiral lines very shanp and the cross strix very weak; this one occurs in the St. Louis-Chester stage of latesville, Ark.: the other lats the spiral lines and cross stria of almut explal strength, and rery sharply defined crenulations; this ocents in the st. I.unisChester stage, the Bend formation of central Texas (Glyphioceras cumminsi Hyatt, Pl. X, figs. 1-11), although it seems to the writer that Hyatt has included under this designation specimens of both $G$. striatus and G. crenistria. In youth these varieties can not be distinguished from each other, nor from $G$. crenistria, which is associated with them.

Goniatites kentuckiensis Miller is probably identical with this species, but until a specimen is found showing constrictions it is left under its present name.

Occurrence.-Goniatites striatus is characteristic of the upper part of the Lower Carboniferous in Great Britain, Belgium, and (xemany, and is considered a typical zone fossil in that region. We may therefore extend the term zone of Goniatites striatus to the same horizon in America, the St. Lomis- ('hester stage, in which this species has been found nealr Batesville, Ark. (Pl. XXVI, figs. 6-13), and in the Bend formation near Lampasas, 'Tex. (Pl. X, figs. 1-11). The specimens figured on Pl. XXVI, figs. 6-13, in this paper are deposited in the geologic collection of Leland Stanford Junior University, and eame from the st. Lomis-( thester lueds (Fayetterille shale) of laatesville, Ark. Those figures on I'l. X, tign. 1-11, came from the Bend formation near Lampasas, Tex., and are deposited in the Texas State Museum:

\section{Goniatites subcircularis Miller.}

Pl. XXVI, figs. 14-18.

1889. Goniatites subirculurix, S. A. Miller, North Ameriean Geol. and Pal. p. 40. fig. $7+1$.

This species resembles some what (t. striatus, but has wider umbilicus, coarser spiral strix, more compressed whorl, and lacks entirely the MON XIII $-02-6$ 
(remulations seeth on most other species of this group. Constrictions deeply incised, four to a revolution, bending sharply forward on the abdomen.

Occurrence.-Lower Carboniferous, St. Louis stage, Crab Orchard, Ky., and the same horizon in the so-called Fayetterille shale of Batesville, Ark. The figured specimens came from the Arkansas locality, and are

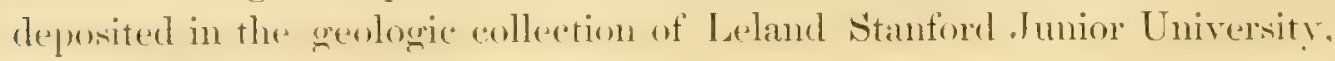
California.

\section{Genus Gastrioceras Hyatt.}

This genus was originally established by Hyatt ${ }^{a}$ to include evolute species with open umbilicus, trapezoidal or semilunular cross section, and usually ribs or tubercles on the sides; the species included by Hyatt

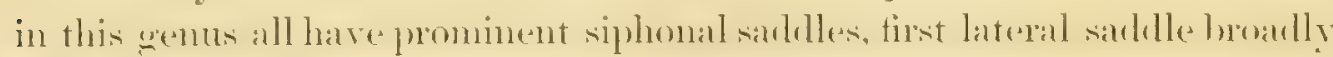
rounded, second lateral saddle broad, but inclined to be pointed; the siphonal lobes are long, narrow, and pointed, and the lateral lobes broad and pointed. In all the species cited by Hyatt as belonging to Grastrioceras, there is but a single pair of lateral lobes visible-that is, on the sides of the shell; and Hyatt ${ }^{c}$ limits Gastrioceras to forms with a single pair of lateral lobes and with the second pair on the umbilical shoulders. Hyatt refers $G$. messiense Tzwetaev to his genus I'aralegoceras, because that species has the second pair of lateral lobes on the sides of the shell and not on the umbilical shoulders. But Gastrioceras vussiense has just the same number of lobes as all other known species of Gastrioceras, namely, nine in all, and lacks the lobe ou the umbilical border, which is characteristic of Paralegoceres. Dr. K. von 'Zittel" confines Gastrioceras to forms with a single pair of lateral lobes. But the relations of Gastrioceras, Glyphioceras, Goniatites, and Paralegoceras have been best worked out by Karpinsky, who shows that there is no marked distinction between Goniatites and Gastrioceras: that both have the same number of lobes and saddles-nine of each; that the second pair of lateral lobes may be on the umbilical shoulders or on the sides of the shell, thus differing from Paralenoceras, in which the

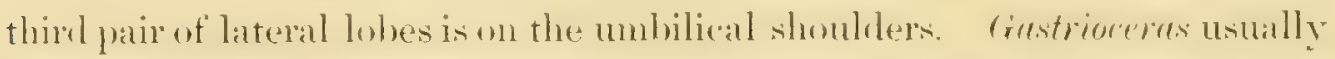
has a trapezoblal cooss sectiom and umbilical ribs: hut somespecies lack the

\footnotetext{
"Proc. Boston Soc. Nat. Hist., Vol. XXII, p. 327.

b) Ibid.

c Second Ann. lept. Geol. Surv. Texas, 1) 355.

"l Ibirl.

e Grundzüge cler Palıeont., p. 349.
} 
are three in number, a long, narrow, pointed antisiphonal lobe, and a pair of shorter, pointed lateral hobes: the four internal saddles are romoled. The figures on Pl. XI, figs. 12 and 13, show the sutures to be (halacteristic of Gastrioceras; but the second lateral lobe, while on the umbilical shoulders, is plainly visible from the outside. Thus the species might be referred to the genus l'ureleforeras of IIyatt; but it has culy nine lobes and nine saddles, while Paralegoceras has eleven of each.

Surface characters.-The shell is preserved on only a small portion of the specimen, but the cast shows the generic and specific elaracters quite as well. Obscure and somewhat doubthil comstrictions were observed, hut the preservation is such that their interval could not be ascertained. The umbilical shoulders are marked with rathere weak nodes or ribs, which on the outer whorls reach up nearly to the abdominal shoulders: on the roumg shell they are relatively much stronger.

Affinities.-Gastrioceras brameri belongs to the group of $G$. listeri

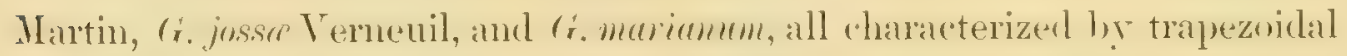
cross section, umbilical ribs, pointed lohes and rounded sardles, and evolute whorls. From the above-mentioned species G. branneri differs in the narrowness of its whorls, and wide, shallow umbilicus; it seems to depart

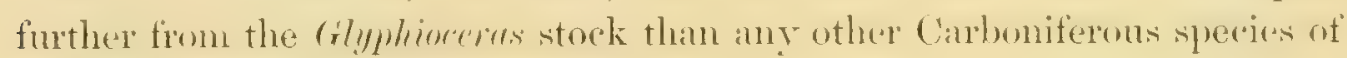
the genus Ciastrioceras.

Occurrence.-Gastrioceras branneri was found along with Pronorites

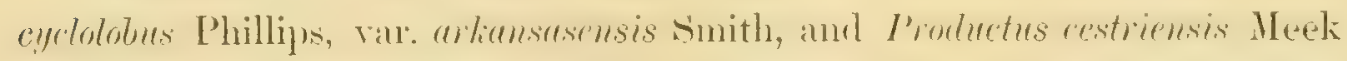
and Worthen, in Arkansas, on Pilot Mountain, (arroll County, 3! miles southwest of Valley Springs, in T. 17 N., R. 19 W., sec. 18, northeast corner, in Lower Carboniferous, Chester groul) (A10 of Prof. H. S. Williams's section).

The type, for the use of which the writer is indebted to Prof. H. S. Willians, is the property of the U. S. Geological survey (U. S. National Museum), locality number 1275.

\section{Gastrioceras carbonarium von Buch.}

Plate XI, figs. $1-4$.

1832. Ammonites carbonarius (pars), L. von Buch, Phys. Abhandl. Berlin Akad. der Wissenschaften for 1830 , p. 176, Pl. II, fig. $9 \mathrm{IV}$, (not 9, 9 I-III).

1842. Goniatites carbonarius (pars), d'Archiac and Verneuil, Trans. Geol. Soc. London, 2d series, Vol. VI, p. 382. 


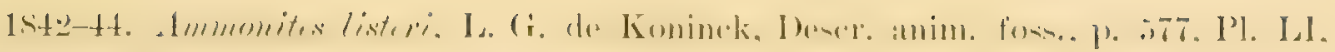
figs. $4, a-b$.

1861. Goniatites listeri, J. W. Salter, Mem. Geol. Survey, Iron Ores of Great Brittain, Pt. III, p. 221, Pl. I, figs. 35. 36.

1863. Goniatites listeri (pars), F. Roemer, Zeitschr. Dentsch. Geol. Gesell., Vol. XXXVI, 1) 213.

18st. Glyplioceres curbonarium (pars), A. Hyatt, Proc, Boston, Soc. Nat. Hist.. Vol. XXII, p. 329.

1590. Goniutites listeri, J. Ward, Trans. N. Stafls. Inst. Min. and Mech. Eng., Vol. X. Pl. I, tigs. 4, i.

1892. Goniatites listeri, G. Wild, Truns. Manchester Geol. Soc., Vol. XXI, p. 396, Pl. II, figs. 9, 10.

1896. Gastrioceras, sp. indet., J. P. Smith, Proc. An. Philos. Soc., Vol. XXXV, p. 262, Pl. XX, figs. 1, a, b, c, d.

1896. Goniatites crrbonarius, H. Bolton, Trans. Manchester Micros. Soc., 1895. p. 130, H. II, fig. 20 .

1897. Gastrioceras curbonarim, Foord and Crick, Catal. Foss. Ceph. Brit. Mus.,

Pt. III, p. 229, tigs. 110, a-d.

1898. Gustrinceras listeri (pars), E. Haug, Études sur les Goniatites, p. 103.

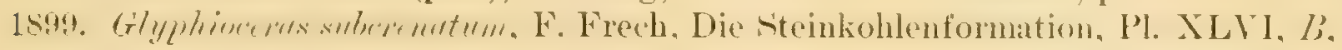
figs. 3 and 5.

[Not 18t0. Goniatites carbonarius, I. de C. Sowerby, Trans. Geol. Soc. London, 2d series, Vol. V, p. 703, Pl. LII, figs. 8, 9.]

Form somewhat compressed laterally; whorls helmet-shaped, wider than high, highly arched, and indented to nearly one-half the height by the preceding whorl. Greatest breadth at the umbilical margin. Umbilicus wide and deep, imner area steep. In the adolesent stage the whorts are broad, low, and flattened, with angular sides exactly like those of G. listeri.

The sides are ornamented with strong tubercles, which on the young stages are like those of G. listeri, but at maturity form ribs that reach halfway up to the abdomen.

Three or four constrictions are seen on each revolution. Outer shell with fine cross strixe of growth, visible on the cast. The ventral lobes are sharp and narmow, the lateral lobe narrower than is msual with restrioredas, and not tongue-shaped.

The inner whorls are flattened and angular, with much stronger tubercles than those on the mature shell.

E. Haug" has included not only this species, but also $G$. coronatum 
Foord and Crick, in (r. listeri, hut these there differ in septa, in involution, and shape of the whorl, r. listeri heing intermediate between the others. and no transitions from one to the other being known.

Occurrence.-Gastrioceras carbonarium is characteristic of the middle division of the Coal Measures in England, Belgium, and Germany. In America it has been found at the same horizon in westem Arkansas-Scott County, near Boles-associated with G. listeri. The identification is not beyond question, on account of the nature of the preservation of the specimens. It is therefore referred with some doubt to G. carbonarium. Figured

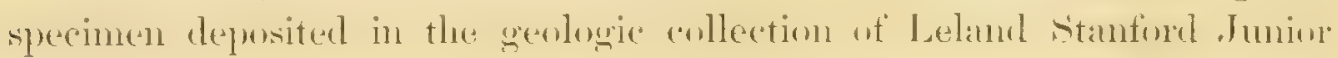
University.

\section{Gastrioceras compressum Hyatt.}

Pl. IX, figs. 1-3.

1891. Gastrioceras compressum, A. Hyatt, Second Aun. Rept. Geol. Surr. Texas, p. 355 , figs. 57,58 .

The following description is quoted from Hyatt's paper:

The form of the whorl is helmet-shaped, and at the diameter of $109 \mathrm{~mm}$. in an cast the greatest transverse diameter was $42 \mathrm{~mm}$; the distance in a straight line from umbilical shoulder to center of abdomen, $38-39 \mathrm{~mm}$.; the abdomino-dorsal diameter. $23 \mathrm{~mm}$. The increase by growth in both diameters is slow and the umbilici consequently shallow. The involution covers more than two-thirds of next internal whorl at the diameter of $109 \mathrm{~mm}$., and in another specimen at diameter of $68 \mathrm{~mm}$. it is just two-thirds. The still younger whorls are numerous and visible from the sides at the centers of the umbilici, and doubtless the amount of involution is correspondingly less. Constrictions appear in the smaller specimen measured and in the younger stages of another flattened example.

The ventral lobe is divided by a large bottle-shaped siphonal saddle divided by a siphonal lobe at the extremity; the lateral branches of the rentral lobes are very long and acutely pointed, as are also the first lateral lobes, which are of the same length as these branches of the ventral. The first lateral saddles are hastate and acutely pointed, and second lateral saddles are, as is usual in this genus, subhastate. The inner outlines of these last are concave near the points, then suddenly convex internally where the lobe of the umbilical shoulder hegins. These last-mentioned lobes are also acutely pointed, but much more abhreviated than the other two pairs. The shell is strongly striated, but it is not pilated or otherwise marked, except when constrictions oceur.

Occurrence-Lower Carboniferous, St. Louis-Chester stage, Bend formation, San Saba County, near Bend, Tex. The type is deposited in the U. S. National Museum. 


\section{Gastrioceras entogonun Gabl).}

Plate X, figs. 17-19.

1861. Goniatites entogonus, IV. M. Gabb, Proc. Acad. Nat. Sci. Phila, 1861, p. 372. 1893. Gustrinceres entogonum, 1. Hyatt, Fourth Ann. Rept. Geol. Surr. Texas, p. 472, Pl. XLVII, tigs. 49-51.

'The following description is quoted from Hyatt's paper:

This species is similar to others of the genus in its open umbilici and the areuate trapezoidal outline of the whorl in section. The cast is mitrked by deep constrictions, confined to the abdomen, and somewhat less than one-third of a volution apart, or about three and five-tenths to one rolution. These bend forward on either side and then back, forming two crests and a median sinus on the abdomen. The sides are dirergent, narrow, and smooth. The abdomen is strongly furrowed and ridged on the shell, and these markings are repeated on the cast. The longitudinal ridges are crossed by strong lines and narrow lamine of growth, which are to a greater or less extent impressed upon the surface of the cast, as shown in fig. 51 [in Hyatt's paper]. The lines of growth and the constrietions are exactly parallel on the abdomen, and the apertures were probably similar in outlime.

The shell was seen only in small fragments, but there is sufficient of these to show that it was not very thick, and ornamented by contiuuous ridges mach sharper than those on the cast. These were crossed and slightly serrated by fine transverse lines, oceurring as the edges of narrow lamina of growth. The sides are smooth except for the presence of the edges of these same lamine. But there is one patch near the line of involution having a ridge with the usual crenulations. The ridges on the renter cross the constriction of the cast helow without any inflection. the constriction being caused entirely by the internal thickening of inner layer of the shell.

This species differs from Gast. listeri of Europe in the smoothness of the shell on the sides and the extent of the involution, which is here coextensive with the abdomen of the whorls, and also in the strong ridges on the abdomen.

The sutures were also visible on the specimen and are of the usual gastrioceran type.

Occurrence-Lower Carboniferous, St. Louis-Chester stage, Bend formation, 5 miles west of Lampasas, 'Texas. A similar species, thought to be identical with $G$. entogonum, was found by the geological survey of Arkansas in the Lower Carboniferous, Fayetteville shale, near Boles, Ark. In both Arkansas and 'Texas this species was associated with Goniatites cumminsi of Hyatt, or Goniatites striatus, according to the writer. 


\section{Gastrioceras excelsum Mleek.}

\section{Pl. XVI, fig. 2; Pl. XXVIII; Pl. XXIX.}

1866. Goniatites globulosus (pars), Meek and Worthen, Geol. Surv. Illinois, Vol. II. p. 390, fig. 38 (not Pl. XXX, figs. 2 a-c).

1576. Goniatites globulosus var. excelsus, F. B. Meek, Bull. U. S. Geol. and Geog. Surv. Terr., Vol. I, No. 6, p. $\$ 5$.

1596. Gastrioceras excelsum, J. P. Smith, Proc. Am. Philos. Soc., Vol. XXXV, p. 260. Pl. XVI, figs. 1 a, b, c.

This is the largest known species of Carboniferous ammonoids. A specinen from () sage, Kans., now deposited in the Lniterl States National Insetum, has a diameter of 11 inches, and is entirely septate, so that the full size, with the complete hody chamber, must have betell several inchess more. Shell globose, with depressed helmet-shaped whorls, and abruptly rounded umbilical shoulders. Width of whorl nearly equal to the tortal diameter of the shell, and more than twice the height of the whorl. Fach whorl indented to one-third of its height by the inner volution.

Surface apparently smooth except for obscure traces of nodes on the umbilical shoulder.

Umbilicus deep and wide, being more than one-third of the total diameter in wilth. Septa of the usual gastrioceran type, rentral lobes long, narow, and pointed, divided by a broader siphonal saddle. Lateral lobes longer than the ventral, and very little wider. First and second litteral saddles broadly rounded. A third lateral lobe, short and fumel shapeed, is seen below on the umbilical slope of the umbilical shonlder. This is not shown in the sketch on PI. XXVIII, fig. 2, which stops at the umbilical shoulder, but can be seesn on fig. 1, from at photogeraph of the shell. Internal septa unknown.

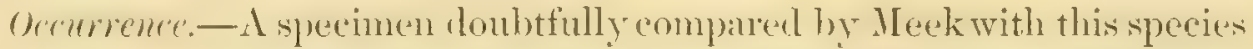
Wals found at an unknown locality in the Tpper Coal Mealsures of Kansas, and figured in geological survey of Illinois, Vol. II, p. 390, fig. 38.

This type was fomul in the Upper Coal Measures of eastern Kansas at Osage. This is the specimen now deposited in the ['nited States National Musemm. In the paleontologic collection of the Walker Insemn, Iniversity of Chicago, is a specinten, No. 6226, from the Upler ('nal Measures of Osage, Kins.; this is better preserved than the type, and has therefore been figured on Pls. XXVIII and XXIX. The writer's thanks are due Dr. Stuart Weller, of 
the Iniversity of " 'lowenge, for the opportunity of stmlying the specimen,

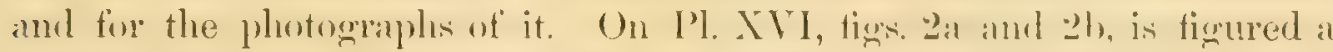
specimen from the Middle Coal Measures of Pope ('ounty, Mrk., 'T. 10 N., R. $20 \mathrm{~W}$., sec. 8, collected by the geological survey of Arkansas, and now deposited at Leland Stanford Jumior University.

Gastrioceras globulosum Meek and Worthen.

Pl. VI, fig. 1; P1. XXI, figs. 7-9.

1860. Goniatites globulosus, Meek and Worthen, Proc. Acad. Nat. Sci. Phila., 1860, p. $t i 1$.

1866. Goniatites globulosus, Meek and Worthen, Geol. Surv, Illinois, Vol. II, p. 390. Pl. XXX, fig. 2.

18st. Gestrioceres globulosem, A. Hyatt, Proc. Boston soe. Nat. Hist.Vol., XXII, p. 327.

1896. Gastrioceras globulosum, J. P. Smith, Proc. Am. Philos. Soc., Vol. XXXV, p. $258, \mathrm{Pl}$. XVIII, figs. $1-6$.

1598. Glyphioceras globuiosum, E. Haug, Études sur les Goniatites, p. 26.

This species has some slight resemblance to I'araleyoreras buylorenser of the Texas Permian, but the lobes of the latter are alone sufficient to separate the species, exceeding by one the number on the sides of 'tr. glolulosum. The Texas species also has the umbilicus much wider and more open, and is not so giobose.

The angle of the umbilicus is $45^{\circ}$, which remains constant notwithstanding the fact that the shell grows more involute with age, being in its gouth a companatively open coil. In youth the whorls are flattened, but with age they become more rounded, until the shell reaches almost the form of Goniatites sphericus Martin. As many as six whorls are known.

The deeply marked constrictions, that are so common in the family of the Glyphioceratidx, are seen on the casts, about four to a whorl.

Sutures.-The sutures show nine lobes and nine saddles; the siphonal lobes are narrow and printed, the first lateral lobe is loroul, but pointed, and on the umbilical sloulder is a small, pointed "suspensive" lobe. There are three pointed, internal (concealer by the involution) lobses, of which the antisiphonal (dorsal) is the longer.

The siphonal saddle is rather deeply notched, long and narrow; the two lateral saddles are bromi and rounder. The two internal saddles are rather pointer and long, as is the ease with most species of this genus. 'The internal lobes and sudlles have never been seen before in this speries. 
The septa are exactly like those figured by Meek and Worthen, so that no further description of them is necessary; they are typical of the genus Gastriocevas, as characterized by Hyatt, although as Karpinsky ${ }^{a}$ remarks, the sutures alone are not sufficient to separate the genera Glyphioceras and Gastrioceras, since a comparison of the sutures of

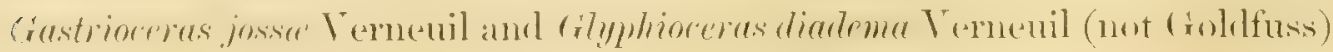
shows the almost perfect similarity of the two.

The surface of the shell was unknown to Meek and Worthen, but some of the Arkansas specimens have the shell partially preserved. It is marked with fine, sharp, doubly arcuate, sickle-shaped stria or ribs, with the sinus on the ventral portion pointing backward. The surface ornamentation resembles that of Glyphioceras obtusum Phillips, ${ }^{b}$ but the form is much more globose, and the lobes unlike those of P'nillips's species.

Dimensions.-One of the fragments shows a diameter of over 2 inches; on this only the body whorl was seen, it being at least one coil in length.

Dimensions of the largest figured specimen.

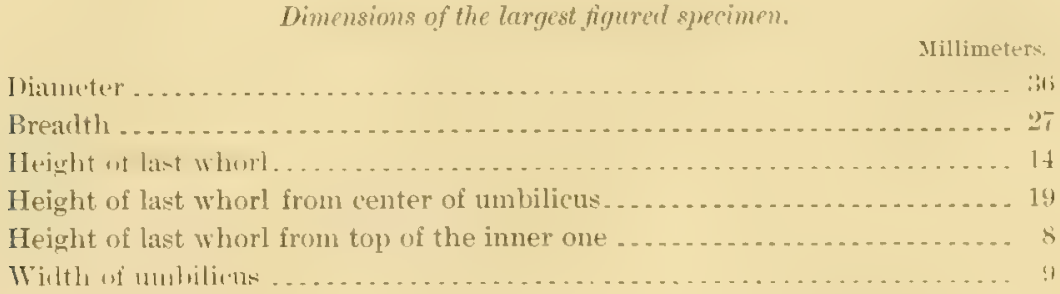

These measurements show the adult shell to be very globose.

Occurrence.-Several specimens of this species were found in the Middle Coal Measures of Seott County, Ark., T. 1 N., R. 28 W., sec. 4, SE. 1 of SE. 1. This species is also found in the Cisco formation of the Texas Upper Coal Measures, and in the Upper Coal Measures of Springfield, Ill. The specimen figured on Pl. XXI, figs. 7-9, came from the Upper Coal Measures, Cisco formation, of Graham, Tex., and has been deposited by the writer in the U.S. National Museum.

"Ammoneen der Artinsk-Stufu, 1".46.

GGeol. Yorkshire, Pt. II, ]. 235, I'l. XIX, figs. 10-13. 
Gastrioceras iluinotsensi: Miller and Gurley.

Pl. XVII, figs. 6-8.

1896. Goniatites illinoisensis, Miller and Gurley, Buil. Illinois State MIns. Nat. Hist. No. 11, p. t2, PI. V, figs. 6-8.

1898. Pumlegocerce illinoisense, E. Hang, Études sur les Goniatites, p. B1.

The following description is quoted from the paper by Miller and Gurley :

Species medium size, subglobose, volutions moderately enlarging, and periphery broadly rounded. One specimen exposes part of three volutions, leaving the impression that il complete shell contained not less than six volutions. A transverse of a volution is suberescentiform, the horns being short and obtuse. The last volution incloses all the inner ones, but leaves a rather large open umbilicus. The air chambers are short and complicated. The outer shell is not preserved in our specimen.

'The septa are gastrioceran in character', consisting of a pair of ventral lobes divided by a blunt siphonal saddle, a principal lateral lobe, and a broad, shallow, pointed, fumnel-shaped auxiliary. The saddles are clubshaped, and the rentral and first lateral lobes mucronate.

This species certainly belongs in the same genus with Gastrioceres hicuscesense Miller and (xurley, of which the writer has satisfient hinself hy an examination of the types of the two. Haug referred this species to

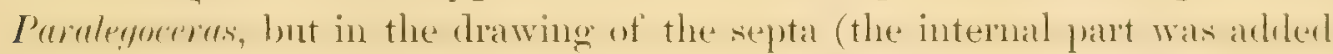
to the original drawing from a sketch of the tye hy Dr. Stuart Weller) it is seen to lack the fourth external lobe that is characteristic of Paralcgocercs, and to have the normal number of lobes, external and internal, characteristic of Gastrioceras.

Occurrence-Upper Coal Measures, Montgomery County, Ill. 'Type specimen is deposited in the paleontologic collection, Walker Museum, University of Chicago.

Gastrioceras ransasense Miller and Gurley.

Pl. XVII, figs. 9-11.

1896. Goniatites Kansasensis, Miller and Gurley, Bull. Illinois State Mus. Nat. Hist. No. 11, p. 43, Pl. V, tigs. $4-11$.

Shell small, subglobose; whorls slowly increasing in size, depressed helmot-shaped and deeply embratoing, indented to half their height hy the 
preceding whorls. Breadth of whorl about two-thirds of the total diameter of the shell and nearly twice as great as the leight of the whorl. L'mbilicus wide, its wilth heing more than a third of the total cliameter of the shell. Surface of the shell smooth, not marked by ribs.

According to Miller and Gurley, this species differ's from r. illinnisense in its larger umbilicus, more depressed whorls, less gibbous shape of the whorls, creater aloruptuess of the cumbilical shoulders, and greater simplicity of the septa, which are decidedly mucronate in Gr. illinoisense and

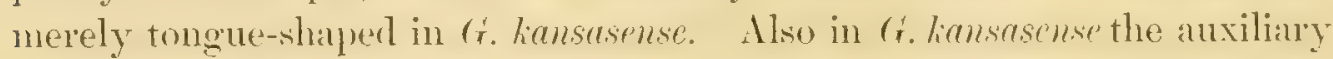
lobe is on the mmbilical border, while on $(x$. illinoisense it is om the umbilical sope, just helow the shoulder. Both species belong to the group of ir. glubulosum, characterized loy ghlobose whorls and absence of umbilical nodes or ribs, thus differing from the species that have been comsidered typical of Geastrioneras. 'This seems to be a rather specialized group that has lost the nodes entirely, and retains the constrictions only in the young.

Occurrence-Upper Coal Measures, Missourian stage, Kansas City, Mo. The type is in the palcontologic collection, Walker Museum, University of Chicago.

Gastrioceras kingi Hall and Whitfield.

Pl. IV, figs. 4-8.

187\%. Gromintites kingi, Hall and Whitfield, U. S. (rool. Expl. Fortieth Parallel, Vol. IV, Pt. II, p. 299, Pl. VI, figs. 9-1t.

1854. Grastrioceras Kingi, A. Hyatt, Yroc. Boston Soc. Nat. Hist., Vol. XXI, p. 327. Shell subghobose, the breath of the whork beding about two thirds of the total diameter of the shell and aloont twice as great as the height of the whorl. Whorls with flattened lorad venter, depressed helmet-shaped ontline, abrupt angular umbilieal shoulders, the umbilical border having an inclination of $45^{\circ}$ with the axis of the shell. Lmbilicus wide, being about one-half of the diameter of the shell. Whorls deeply embrateing, each one covering the inner whorl to near the umbilical shoulder, and heing indented by this to one-half its height.

Surface ornamented by obscure nodes on the umbilical shoulders, sometimes forming faint undulations across the abdomen. The whole surfice is covered by fine lines of growth, the crowding together of which causes the undulations. Surface of the cast marked by constrictions, about two to a revolution. 
Septa of the usual enstrioceran type: ventral lobes narrow and long.

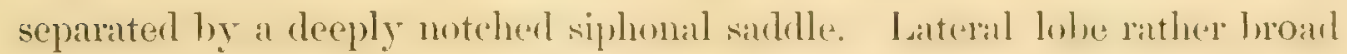
and fumel-shaped. Extermal and lateral sablles brombly rombled. The secomet lateral lobe is not abore the mubilicus. Bonly chamber at least two revolutions in length.

Occurrence.-In black shale of the Coal Measures, presumably the "plere part, near Eherhartt Mill, Whice P'ine, Ner. The type is deposited in the U. S. National Museum.

\section{Gastioceras listeri Martin.}

$$
\text { Pl. XIII, figs. 6-15. }
$$

1809. Conchyliolithus Nautilites Ammonites (listeri), W. Martin, Petrif. Derb., PI. XXXV, fig. 3, and p. 16.

1825. Ammonites listeri, J. Sowerby, Min. Conchol., Vol. V, p. 163, Pl. DI, fig. 1 (right and left hand figures).

1832. Ammonites listeri, L. von Buch, Phys. Abhandl. Berlin Akad. der Wissenschaften for 1830, p. 175.

1833. Ammonites listeri, C. J. Davreux, Mém. Cour. Acad. Roy. Bruxelles, Vol. IX, p. 270, Pl. III, figs. 1, 2.

1836. Goniaútes Tisteri, J. Phillips, Geol. Yorkshire, Pt. II, p. 235, Pl. XX, figs. 1, 1a. 1842. Goniatites listeri, F. McCoy, Synop. Carb. Foss. Ireland, p. 14.

1842-14. Ammonites listeri (pars), L. G. de Koninck, Descr, anim. foss., p. 577 (excluding figures).

?1855-57. Goniatites Tisteri, J. Kelly, Jour. Geol. Soc. Dublin, Vol. VII, p. 7.

1863. Goniatites listeri, F. Roemer, Zeitschr. Deutsch. Geol. Gesell., Vol. XV, p. 580 (excluding figures).

188t. Gastrioceras listeri, A. Hyatt, Proc. Boston Soc. Nat. Hist., Vol. XXII, p. 327. 188t. "Ammonites listeri," E. Beyrich, Zeitschr. Deutsch. Geol. Gesell., Vol. XXXV1, p. 213.

1885. Goniatites listeri, R. Etheridge, British Fossils, Vol. I, Palæozoic, p. 312.

1892. Goniatites striatus, G. Wild, Trans. Manchester Geol. Soc., Vol. XXI, p. 396. Pl. II, fig. 11.

1896. Goniatites listeri, H. Bolton, Trans. Manchester Micros. Soc., 1895, pp. 130. 13t, Pl. II, tig. 21.

1896. Gastrioceras marianem, J. P. Smith, Proc. Am. Philos. Soc., Vol. XXXV, p. 260, Pl. XVI, figs. 1-5.

1897. Gastriocercas listeri, Foord and Crick, Catal. Foss. Ceph. Brit. MIus, Pt. III, p. 233, fig. 111 .

1898. Gastrioceras listeri (pars), E. Haug, Etudes sur les Goniatites, p. 103, PI. I, figs. 25-31.

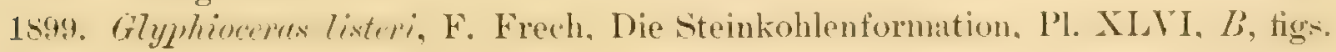
$2 \mathrm{a}-\mathrm{b}$. 
The whorl is low, broad, with trapezoidal cross section, very evolute, hroader than high; indented about onte-half the height by the preceding whorl. Greatest breadth at the umbilical margin, about three-fourths the diameter: height of the whorl about two-sevenths the diameter amb less than half the brealth. Umbilicus broad and deep, width about one-half the diameter. Strong umbilical tubercles, which are continued across the abdomen by fine undulations. About three constrictions to a revolution. Outer shell with fine cross strix, and obscure spiral strix on the inner whork. Septa consisting of a pair of tongue-shaped narow ventral lobes, and a somewhat shorter and broader lateral lobe. On the umbilical shoulders is a small shallow "suspensive" lobe. The saddles are all broadly rounded.

This species has been united by many writers with Gastrioceras carhonerium, but is always broader and more depressed, has stronger unbilieal tubereles and broarler lateral lobes than that species. Some have confused it with G. mariamum II. V. K., and the American representative has been referred by the writer" to that ipeceles. But the figures and descriptions of Foord and crick enable these two specties to be distinguished quite easily: G. listeri is not quite so involute as G. marianm, is always broader and coarser in sculpture. The breadth of the whorl in G. listeri is more than three-fourths of the diameter, in $G$. mariamm it is only two-thirds of the diameter. Also in G. listeri the lobes are proportionally longer and narrower.

Occurrence.-In England, Belgium, and Germany Gastrioceras listeri is characteristic of the middle division of the Coal Measures. In America it has been found in the same horizon near Boles, Scott County, Ark., accompanied by ci. curbonarium. It may thus be taken as diagnentic for this zone in these two regions.

The figured specimens came from near Boles, Scott County, Ark., and are deposited in the geolngic collection of Leland stanford Junior University, California. 
Gastrioceras montgomeryense Miller and Gurley.

Pl. XVI, figs. 12-14.

1896. Gromiatites montyomeryensis, Miller and Gurley, Bull. Illinois State Mus. Nat. Hist. No. 11, p. 3s, Pl. IV, figs. 12-14.

Shell robust, breadth nearly as great as the diameter; whorls slowly expanding, three times as broad as hight, deeply embraing, the outer wherl being indented to one-halt its height by the imer one, hut the mubilinal shoulders of the imner whorls are exposed in the deep fumnel-shaped umbilicus. ('ross section of whork depressed, traprezoidal, hrobler than is usual in Gastrioceras. Ventral portion flattened and broad; umbilical shoulders montar and abrupt, descending stereply to the umbilicus, and crnamented with sharply incised ribs ar notes. C'mbiliens wide and deep, being one-half of the total diameter of the shell.

There are six constrictions to a revolution, beginning at the umbilical borter, curving abruptly forward on the sides and then backwart on the abdomen in a broad, gentle series.

Septa consisting of a pair of narrow tongue-shaped ventral lobes, separated hy a short siphonal saddle, decply incised by a secondary notreh or lobe; a broad, short, lateral lobe on the sides halfway between the siphon and the umbilical shoulders.

This species is most nearly related to Gastrioceras listeri, but is broader in proportion, and also has a greater number of constrictions to a revolution. The lateral sculpture is slightly coarser than on G. listeri.

Occurrence.-Upper Coal Measures, Montgomery County, Ill. 'I'ype in the paleontologic collection, Walker Museum, University of ('hicager.

Gastrioceras nolinense: Cox.

$$
\text { Pl. V, figs. 8-10. }
$$

1857. Goniatites nolinensis, E. T. Cox, Geol. Surv. Kentucky, Vol. III, p. 57t, Pl. X, figs. 1, 1a, 1b.

1891. Goniatites nolinensis, C. R. Keyes, Proc. Acad. Nat. Sci. Phila., 1891, p. 264.

Form subglobose, somewhat compressed laterally. Whorls highly arched, with broadly rounded abdomen and slightly flattenet sides, deeply embracing, and covering most of the inner volutions. Umbilical shoulders abruptly rounded, umbilicus narow, being not over one-fifth of the totil 
diameter. Surface smooth, but ribs and constrictions might possibly not be preserver by the iron ore by which the shell is replaced. Septa consisting of hastate lohes and tongue-shaped saddles; siphonal saddle long, mucronate, rentral siddles long and tongue-shaped, lateral saddle broadly rounded; rentral lobes narrow and hastate, lateral lobes broader and pointed, second lateral or anxiliary lobe on the umbilical border. The antisiphonal bohe is long, narrow, and pointed, flanked by a pair of shorter hastate lobes and narrow tongue-shaperl saddles. The internal lateral saddles are very broad and shallow.

This species seems to be nearest akin to Gastrioceras carbonarium, with which its form and septa agree, but the smoothness of the shell of ' $r$. nolinense would serve to distinguish them, if it should be proved that the sperimens are always devoid of ornamentation.

Occurrence_-Middle Coal Measures, Nolin, Edmonson County, Ky., and Iles Moines formation, Middle Coal Measures, of Des Moines, Iowa.

\section{Gastrioceras occidentale Miller and Faber.}

Pl. VIII, figs. 6 and 7 .

1592. Goniatites occidentalis, Miller and Faber, Jour. Cincinnati Soc. Nat. Hist., Vol. XIV, p. 166, Pl. VI, figs. 6 and 7.

Shell sulgglolose, abdomen broadly rounded, sides sloping with a grentic. curve to the abrupt umbilical shoulders. Whorls highly arched, deeply embracing, indented to about one-half of their height by the imner whorls. Embilicus deep and wide, heing about one-third of the total diametere Unbilical shoulder arenulated or submodose. Surtice marked by fom broal, shallow constrietions which run nearly straight across the abdomen. Between these furrows are tine transverse lines of growth, parallel to the constrictions. The septa, as shown by Niller and Faber, do not resemble thene of any known goniatite genus, but are remarkably like the impressions of the internal muscle-scars, as seen on many ammonoids. This is probably what was seen by Miller and Faber and reproduced in the drawing. The septa when seen will probably be like those of other species of Gastrioceras.

Occurrence-Middle Coal Measures, Elkhom Creek, Kentucky. 


\section{Gastrioceras planorbiforme Shumard.}

1855. Goniatites planorbiformis, B. F. Shumard, Geol. Surv, Missouri, Vol. II, p. 208, Pl. C, figs. 11-a-b.

1894. Goniatites planorbiformis, C. R. Keyes, Geol. Surv. Missouri, Vol. V. Pt. II, p. 221.

Shell evolute; whorls depressed, romderl, little ombracing, elliptical rather than trapezoidal in cross section. Sides rounding grently to the abrupt unbilical shoulders, which, however, are not angular. Umbilicus very wide, exposing all the inner whorls, being more than at third of the total diameter.

Surface ornamented with fine imbricating bands of growth, hearing very minute stria, which are flexums on the abdomen; me constriction has been observed at about the end of the fiftl revolution. Septa gastrioceran in eharacter, with lobes inclined to be pointerl, and broally rounded saddles. Shumard's type was very small, and these septa are larval in character, so this probably does mot represent a mature form, but might be the young of any one of several species of Gastrioceras.

Occurrence.-L Puer Coal Measures, Kansas City, Dover's Landing, IIo.

Gastrioceras subcayum Miller and Gurley.

Pl. XVII, figs. 15-17.

1896. Gumietites sulecums. Niller and Gurley, Bull. Illinois State Mus. Nat. Hist. No. 11, p. 45 , Pl. V, figs. $15-17$.

This species wats first described by Miller and Gurley from the Lpper Coal Measures of Montemery County, Ill. The writer has a specimen collected by Dr. N. F. Inratie in the Lpper Coal Ileasures, ('isco formation, of Graham, Young County, 'I'ex., about 1,000 feet below the Permian.

The species resembles Gastrioceras globulosum, but the whorls are narrower, more depressed, more angular on the umbilical shoulders, and less rounded than on that species. The two agree in the septa and in the absence of umbilical ribs.

The figured specimen is in the paleontologic collection, Walker Museum, University of Chicago (Gurley collection).

Occurrence.-Upper Coal Measures, Montgomery County; Ill., and Graham, Young County, 'Tex.

MON XLII-02- 


\section{Gastrioceras welleri Smith, sp. nov.}

Pl. XXIV, figs. 13-20.

Form evolute, widely umbilicate; whorls low and broad, increasing slowly in size. Cross section trapezoidal, ventral arch low. Umbilicus deep, fumel-shaped, with abruptly angular umbilical shoulders. The height of the whorl is one-third of the total diameter, and the width is twice the height. The width of the mubilieus is slightly more than methird of the diameter of the shell. The impresserl zone is abont one-sixth of the height of the whorl. The greatest hreadth of the whorl is at one-half the height.

The surface is ornamented with both cross stria of growth and periodic constrictions. These are seen on both shell and cast. The cross strix are sinuous and show only imbrication of the shell. There are no erenulations nor spiral lines visible. The constrictions on the last whorl are five in number, deeply incised, and slightly sinnous, bending forward in a broad sinus. The cross strixe also form incipient undulations on the shell and cast. The length of the body chamber is at least one revolution.

The septa are typically gastrioceran; the ventral lobe is divided by a narrow siphonal saddle into two short, narrow branches; the principal lateral lobe is deeper, broad and pointed; the second lateral lobe is on the umbilical slope, just outside of the suture.

This species is most nearly related to Gasiriocenas kingi Hall and Whitield, hut differs from that species in its weaker sculpture, fewer constrictions, less highly archerl whorls, and more angular shoulders. The relative dimensions and the septa of the two species are exceedingly similar. 'The species belongs to the group of Gastrioceras globulosum Ifeek and Wrorthen, characterized by rather globose shape and absence of umbilical ribs. But (r. wethri is proportiomally narrower and has a wider umbilicus than G. globulosum.

Occurrence.-In the Middle Coal Measures, Des Moines formation, of Carroll County, Mo., exact locality unknown. The figured specimens are deposited in the paleontologic collection of the Walker Museum, University of Chicago (No.1313). The specific name is given in honor of Dr. Stuart Weller, to whom the writer's thanks are due for the loan of the specimens. 


\section{Genus Pakalegoceras IIyatt.}

This genus was described by Hyatt" to include forms similar in many respects to Grestrioures, but with more highly arohed whorls, helmetshaped rather than trapezoidal in outline, narrower umbilici, and less pronounced sculpture. The septa are of the lanceolate type, both lobes

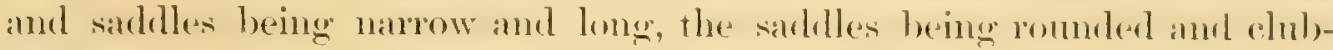
shaped, while the lobes are pointed and tongue-shaped, or mucronate. The lobes on each side are four in number-an external or ventral two laterals, and an auxiliary lobe just on the umbilical border. There are three intemal or dorsal lobes-a long, pointed antisiphonal flanked by two similar laterals. This gives for Paralegoceras eleven lobes in all, one pair more than Gastrioceras posesses.

The type chosen was $P$. iowense Meek and Worthen.

Paralegoceras iaylorense White.

Pl. IV, figs. 9-11.

1891. Goniatites baylorensis, C. A. White, Bull. U. S. Geol. Survey No. 77, p. 19, Pl. II, figs. 1-3.

'The following description is quoted from White's paper:

Shell apparently reaching a moderately large size; its transverse diameter less than that of the plane of its coil; volutions moderately embracing; the peripheral and lateral portions regularly rounded from the border of one umbilicus to that of the other; umbilici deep and somewhat narrow, but showing a portion of each of the inner volutions, their borders abruptly rounded inward from the sides; the transverse diameter of the volutions nearly three times as great as the dorso-ventral diameter, a transverse section of them showing a lunate outline. Living chamber and aperture unknown. Septa moderately distant from one another; dorsal [ventral] lobe longer than wide, deeply divided into two narrow, lanceolate, slightly diverewing bramches; dorsal [rentral] and superior lateral saddles linguiform and nearly equal in size: the two saddles separated hy the superior lateral lobe, which is simple, slightly constricted in the middle, and acutely pointed; the inferior lateral lobe similar in shape to the superior, but a little shorter and less distinetly constricted; inferior lateral saddle a little shorter than the others, somewhat irregular in shape, and occupying the margin of the umbilicus. Surface apparently unornamented.

The only specimen in the collection, when perfect, probably reached a diameter of coil of about 55 millimeter.

This species bears considerable resemblance to the $G$. globulosus of Meek and 
Worthen, but the septa of the Texan form have each one more lobe and saddle between the periphery and the margin of the umbilieus than have those of the other form.

There can be little doubt that this species is correctly referred to Paralegocenas, hecause the amxiliary lobe appears to be on the mmbilical border giving the right number of lobes, although it is not shown in the drawing.

Occurrence-Permian, Wichita formation, military crossing of the Big Wichita River, Baylor County, Tex.

Deposited in U. S. National Museum.

Paralegoceras Iowense Meek and Wrorthen.

$$
\text { Pl. IV, figs. 12-14; Pl. IX, figs. 4-7. }
$$

1860. Goniatites iowensis. Neek and Worthen, Proc. Acad. Nat. Sci. Phila., 1860, p. $\$ 71$.

1866. Gomatites iowensis, Meek and Worthen, Geol. Surv. Illinois, Vol. II, p. 392, Pl. XXX, tigs. 3 a-c.

185t. Paralegoceras iowense, A. Hyatt, Proc. Boston Soc. Nat. Hist., Vol. XXII, p. 327.

1893. Peralegoceras ionoense, A. Hyatt, Fourth Ann. Rept. Geol. Surv. 'Texas, p. 474 , figs. 52-54.

Not 1896. Paralegoceras iowense, J. P. Smith, Proc. Am. Philos. Soc., Vol. IXXV, p. 263, Pl. XIX, tigs. 1-3.

The following description is quoted from Neek and Worthen, in Geological Survey of Illinois, Vol. II, p. 392 :

Shell attaining a rather large size, discoidal or nearly flat on the sides, and narrowly rounded on the dorsum [abdomen]. Umbilical rather shallow, about onehalf as wide as the breadth of the outer whorl from the rentral to the dorsal side, showing apparently about one-third of each inner whorl. Volutions increasing gradually in size, but gently convex on the sides, nearly twice as broad from the ventral to the dorsal side as the trinsverse diameter, and profoundly grooved within for the reception of the inner whorls; aperture, as near as can be determined from a section of the whorls, narrow-subovate, deeply sinuous on the rentral side. (Surface unknown.)

The septa are lanceolate, lobes and saddles all long, narrow, and crowded. Fiddles rounded and tongene-shaped, lobes lancenhte and sharply pointed. The ventral lobe is divided by a siphomal saldle; the first and second lateral lobes are smaller than the ventral; a fourth lobe lies just on the unbilical border. There are therefore eight lobes visible on the ontside, 
one pair more than possessed hy ciastrioureres, with which this genus has sometimes been united.

There is no other species with which this may be compared; the writer ${ }^{a}$ erroneously identified a species from the Lower Conl Measures of Arkansis with $P$. iovense, but further study of the specimen las shown it to be specifically distinet, and it is deseribed in this palper cunder the name of $I$. newsomi. Hyatt has described, ${ }^{b}$ under the name of Paralegoceras iowense Meek and Worthen, a goniatite from the Bend formation of Texas. But the lobes are not exactly like those of the Inwa coal Measuress species, the third lateral saddle is on the umbilical shoulders, and the young shell is marked with rilss which form well-defined tubercles, wen on the older shell. These differences were explained by the supposition that the Texas specimen was the youmg of I'eralegoceres ionense. and might thus naturally show them. The Bend formation is called Coal Measures by the genogoneal survey of Texas, but its famia seems to be identical with that of the Fayetteville shale of Arkansas, which belongs to the Lower Carboniferous, and probably to St. Lonis-Chester stage. Speceses that are alumest certainly

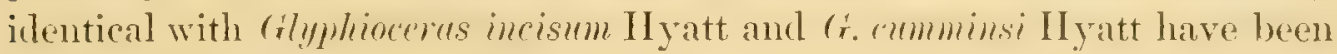
collected in the Fayetteville shale of Arkansas.

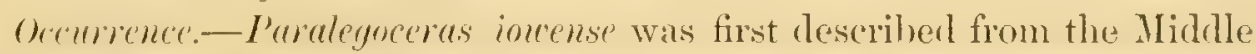
Coal Measures of Alpine, Iowa, and since then has been described from the Bend formation (Nt. Louis-('hester) of Texas, near Bend, San Saba County.

\section{Paralegoceras newsom Smith, sp. nov.}

Pl. XII, figs. 4-9.

1896. Paralegoceras iowense, J. P. Smith, Proc. Am. Philos. Soc., Vol. XXXV, p. $263, \mathrm{Pl}$. XIX, figs. $1-3$.

Not 1860. Goniutites iowensie, Meek and Worthen, Proc. Acad. Nat. Sci. Phila., 1860, p. 471. Not 1866. Goniatites ioncensis, Meek and Worthen, Geol. Surv. Illinois, Vol. II, p. 392, Pl. XXX, figs. 3a-c.

Shell somewhat discoidal, with flattened sides and rounded abdomen. Greatest breadth somewhat above the umbilical border. Umbilical shoulders rounded. Whorl indented to about two-fiftls of its height by the preceding whorl. Height of whorl equal to the breadth, and nearly 
one-half the rliameter. Umbilicus broad and shallow, one-fourth the diameter, and a little over half the height of the last whorl.

Septa consisting of an external lobe, two lateral, and a "suspensive" lobe on the umbilical shoulders; the internal lobes are three in number, long, narrow, and pointed; this gives eleven lobes in all for Paralcyoceras, while Gastrioceras has only nine, and Schistoceras has thirteen or more; that is, four extemal lobes on each side, one on each umbilical shoulder, and three internal. Schistoceras is the only Carboniferous member of the Glyphioceratidae that is known to have more than three internal lobes.

The type specimen is a septate cast that when complete must have been at least 4 inches in diameter. The whorls are broader and rounder than on $P$. iowense. They are quite involute, and the umbilicus is narrow on the young shell, becoming wider as the shell grows older. 'The surface of the cast is smooth, no constrictions or other ornamentations appearing on the older shell. On the younger shell the umbilical shoulders show faint ribs, that shade off into fine undulations on the sides. Hyatt has shown the same thing on $P$. iowense. ${ }^{a}$ But in the Texas specimen the ribs persist to a much later stage than on that from Arkansas.

Dimensions.-Although the specimen was not well preserved, the measurements of the entire form could be taken. They were as follows:

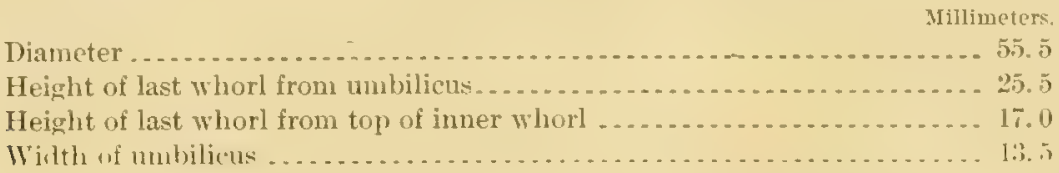

An imner coil taken out of the same specimen gave the following measurements:

Millimeters

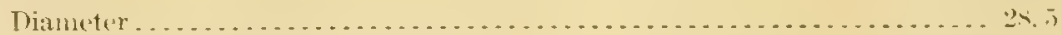

Height of last whorl from umbilicns.............................. 12.0

Height of last whorl from top of inner whorl .................... 7.5

Width of umbilicus ......................................... 6.

These show the inner coils to be much lower, less highly arched, and less embracing than the outer ones.

Surface markings.-On the imner whorls a trace of the shell is preserved, and is like that figured by Iyatt. 'The undulating stria are like those common on the Glyphioceratidx.

Sutures.-The sutures are like those of $P$. iowense figured by Meek and 


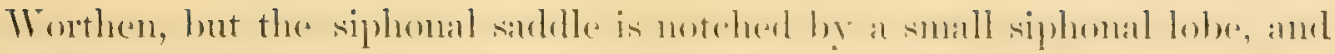
all the lobes are somewhat constricted in the middle. The three external

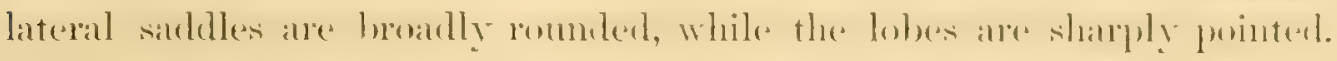
The lobes are eleven in number, three on each side, one on each umbilical shoulder (suspensive lobe) and three intemal, that is, covered by the involution. The interior lateral lobes and the antisiphonal lobe (dorsal) are very sharp and long. 'The sutures approach very closely to those of Gastrioceras russiense 'Tzwetaer, but l'araleyoceras has one more pair of lobes than the Russian species and hes also a suspensive lobe on the umbilical shoulders. In the latter characteristic P'araleyoceras newsomi

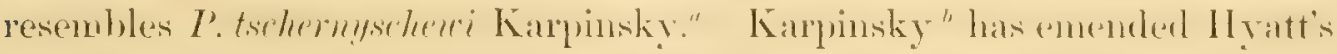
genus to embrace those forms with two lateral lobes and a "suspensive"

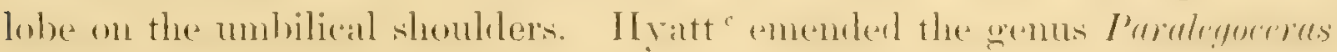
to include those forms with the second lateral lobe on the umbilical shoulders, and he included in it Gastrioceras mssiense 'T'zwetaev. But the Rusilan species hats the suspensive lolw on the side and hat only nine lobes in all, and thus ought to remain in the group characterized as Gastrioceras.

This species was first assigned by the writer" to P'aralegoceras iowense Jeek and Worthen, although differencess were noted. A reexamination of the type and careful comparison with all figures and descriptions of I'orelegoceras shors that this form, while nearest to $P$. iowense, can not correctly be placed under that species. The umbilicus on $P$. iovense and on $P$. nexsomi is one-fourth of the total diameter'. 'The whorl of $P$. iowense has a brealth about three-fourths of its height, while on $I$. nersomi the brealth is nearly equal to the height. The Arkansas species is therefore more globose, with highly arched, helmet-shaped rather than laterally compressed whorls, has a much more rapid increase of size of the whorls, and is more involute and less discoidal than $P$. iovense.

Shumard's description of $P$. texanm suggests a near kinship with I'. nexsomi, but this form seems to be more compressed laterally, more dis-

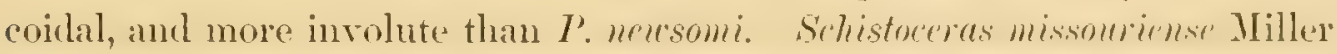
and Faber also resembles this species extemally, hut has one more pair of lobes and saddles, and thus can not be assigned to Paralegoceras.

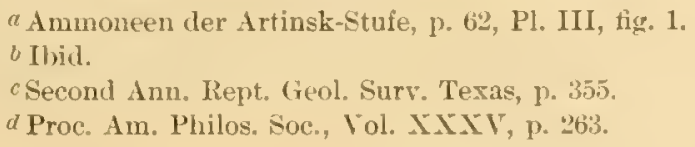


Occurrence.-Paralegoceras newsomi was found in the Lower Coal Measures near Morrillton, Conway County, Ark., T. 5 N., R. 16 W., sec. 14, on the Arkansas River. Specific name in homor of the discoverer, J. F. Newsom. The type specimen is depositer in the geologic collection of the Leland Stanford Junior University.

\section{Paralegoceras texanum Shumard.}

1863. Goniatites texemus, B. F. Shumard, Trans. St. Louis Acad. Sci., Vol. II, p. 109. The following description is quoted from Shumard's paper:

shell large, discoidal, strongly rounded on the dorsum [abdomen], gently convex on the sides, umbilieus deeply exeavated, exhibiting the inner volutions, and having a diameter equal to two-thirds the greatest width of the last volution; margin sulangulated; transerse section of last rolution somielliptical; its dorso-rentral diameter about equal to, or a little greater than, the width from side to side.

A small fragment only of the shell is preserved in one of the specimens in the Texas state collection. It is extremely thin, and the surface is marked with numerous parallel revolving lines, crossed with flexuous transverme lines, presenting a neat cancellated uppearance. There are also faint indications of transverse costre perceptible near the margin of the umbilicus. Septie deeply sinuous; dorsal [ventral] ]obe cleft by a profound linguaform sinus with a broad base, into two narrow, elongated branches, which are not so wide as the sinus between, and which are gently expanded in the middle and narrowed to an acute point at their extrentitien by an ohlique truncature of their immer margins: dorsal [rentral] saddle linguaform, longer than wide and latrger than the hranches of the dorsal [rentral] lobe; superior lateral lobe having nearly the same form as the branches of the lateral lobe, but larger.

This description placen it beyond doubt that the species is a I'aralegoceras, but as it was never figured, and the type is lost, it is difficult to say whether I. framm is equivalent to any of the other species of this genus. It may be the same as $I^{\prime}$. iowense Meek and Worthen.

Occurrence-Lower Carboniferous, St. Louis-Chester stage, Bend formation, Wallace Creek, Sau Saba County, 'Tex.

\section{Genus Schistoceras Hyatt.}

Type of genus, Schistocerce hyatti Smith.

The genus Schistoceras was established by $\mathrm{Hyatt}^{a}$ to includea single species which is not figured or described, but can be readily distinguished by its large bottle-sbaped, sipthonal saddle. This is the only characteristic by which 
it diflers from P'rederenite.s. The two arms of the ventral lobe are widely separated, and there are only three pairs of lateral lobes and a small umbilical lobe with two pairs of dorsal lobes. The lobes are hastate, and the saddles more rounded and club shaped, as in Prolecanites. 'The first pair of saddles have dorsal correspondents, and the annular lobe is deep and acute.

Professor Hyatt's type was never figured, and the existence of any other species belonging to this genus was unknown to him, so it was afterwards either ignored or the species of this group were included in other genera. Foord and Crick" recognized the aftinity of this group with Agathiceras, which was established by Gemmellaro, based on the type A. suessi Gemmellaro, to include Carboniferous ammonoids with rather helmet-shaped whorls, somewhat compressed laterally, with spiral ornatmentation, with fou extemal tongue-shaped goniatitic lobes. Karpinsk ${ }^{\circ}$ subsequently included in this genus Adrianites Gemmellaro, which differed only in having a longer body chamber and a greater number of lobes. But such a character as this has a much greater significance in the simpler goniatites than in the specialized ammonites. Thus a difference in number of lobes may always be taken as indicating cemerio proceress. It therefore seems better to leave the genera as Gemmellaro defined them, except as to their systematic position.

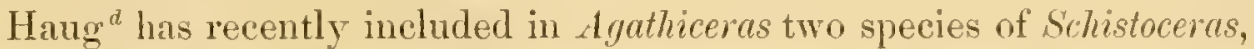
S. fultonense Miller and Gurley, and s. hildrethi Mortom, which he asigned to the Glyphioceratidex. On page 105 of the same work Haug redescribes $S$. hildrethi, and calls attention to the fact that it has one pair of lobes and saddles more than the troe of dyothiceres, and therefore might represent at

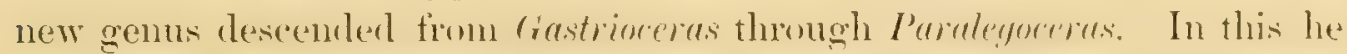
is in perfect accord with the writer, except that it was unknown to Haug that the genus schistoceras met all these requirements. This genus muloulotedly resembles Ayathiceras, but appears to differ in the constant number of lobes and saddles; one external lobe divided deeply by a bottle-slatped siphonal saddle, three lateral lobes decreasing in length toward the umbilicus, a short pointed lobe on the umbilical shoulder; and the internal lobes consisting of a long tongue-shaped undivided dorsal or antisiphomal lohe and two pairs of lateral lobes. There are, then, in all ten extermal and

a Catal. Foss. Ceph. Brit. Mus., Pt. III, p. 269.

${ }^{b}$ Fauna calc. Fusulina, p. 77. c Ammoneen der Artinsk-Stufe, P. 64.

"Etudes sur les Coniatites, p. 33. 
five internal lobes, tour more than are possessed by l'aralegorevas, and two more than Agathiceras.

Professor. Hyatt has kindly turued over to the writer the type specimen of Sirhestoreres, and thromeh the kinduess of In. Stuart Weller the troe of

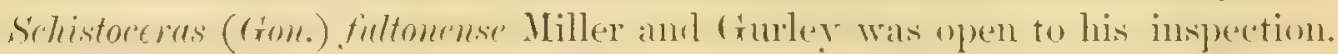

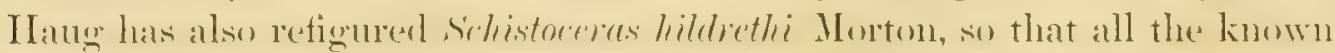
species of this genus were available for study. The type species has nerere been named until now, but the laws of priority demand a recognition of Hyatt's genus.

The ontogeny of $s$. hyutti shews ummistakably that the genus is derived from Gastrioceras through Peralegoceras, and is thus not a member of the Prolecanitidx. It may possibly be an ancestor of the Arcestidx, but that question can be settled only by a study of the ontogeny of the primitive Permian members of this group.

Occurrence.-At present the genus Schistoceras is known only from America, in the Upper Coal Measures.

Schistoceras rultonense Miller and Gurley.

$$
\text { Pl. XVI, tigs. 15-17. }
$$

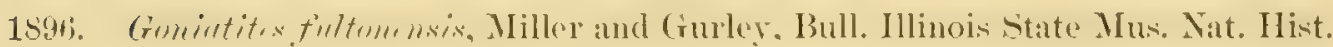
No. 11, p. 39, PI. IV, figs. 15-1\%.

The following lescription is quoted from Miller and Gurler's paper:

Species medium size, subglobose, periphery regularly rounded; volutions rather rapidly expanding. Transverse section of a volution semielliptical, the transierse diameter being a little more than the dorso-ventral. Sumber of volutions not known. The last rolution embraces all the inner ones. ITmbilicus small, open but not disclosing the inner volutions. The sides of the volutions are slightly flattened and inclined toward the regularly rounded periphery. The sides of the umbilicus are ahrupt, and the greatest transverse diameter of a volution is near the abrupt descent to the umbilical cavity. The external shell of our specimen is not preserved.

The septa are lanceolate, the saddles all rounded and tongue-shined, the lohes all pointed and slightly constricted at the middle. The extemal lobe is long, rather broad, and divided by a siphonal saddle of equal breadth. The superior lateral lobe is of equal length and similar to the external; the second lateral lobe is about two-thirds of the length of the superior lateral; the third lateral lobe is rery small and stands well above the umbilical shoulder; on the umbilical border is a fourth lobe similar to 
the third. The internal or dorsal lobes consist of a narrow and pointed antisiphonal lobe, flanked on eithere sicle by a pair of similar laterals, making five internal lobes.

Miller and Gurley did not attempt to assign this species to its proper genus, and $\mathrm{E}$. Hang ${ }^{a}$ ascribed it to Agathiceras. The writer has, through the kindness of Dr. Stuart Weller, examined the type specimen in the paleontolugice collection of the Wralker. Museum, L niversity of ( 'hicatgo, and

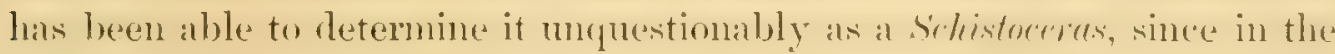
number and character of both external and internal lobes, fifteen in all, it agrees with Hyatt's type specimen.

It is most nearly related to Schistoceras missouriense Miller and Faber, but is more globose than that species and has a slightly natrower unbilicus, which is mly me-fifth of the total diameter of the shell, while in st. missmmriense it is nearly one-fourth. It also resembles $S$. hyatti in the narrow umbilicus, but is more robust than that species and appourently lacks the umbilical nodes. It agreess with st. hildrethi in its robust form, but differs in its narrower umbilicus. It is quite possible that all these species, $S$. fultomense', s. hyutti, and s. hildrethi, may be only local varieties of the sante thing, in which case they would all fall under the synonymy of the latter species. But not enough material is known at present to demonstrate a gradation between them, and they are accordingly lept separated until the discovery of sufficient material should warrant a mion of all or part of them in one species.

Occurrence--Upper Coal Measures, Fulton County, Ill. Type in the paleontologic collection, Walker IInsenn, University of Chicago.

\section{Schistoceras hildrethi Morton.}

Pl. III, figs. 1 and 2.

1836. Ammonites hildrethi, S. G. Morton, Am. Jour. Sci., 1st series, Vol. XXIX, p. 149, Pl. I, fig. 24; Pl. XXVIII, tigs. 48, 50, 53, 5 t.

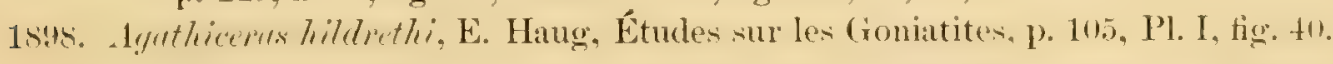

Shell subglobose, involute; whorls highly arched, height being fourfifths of their breadth; helmet-shaped, reeply embracing, concealing all but the umbilical shoulder of the inner whorls, and indented by them to onethird of its height. Limbiliens wide and deep, being nearly one-third of 
the total dianeter. L'mbilical shoulder abruptly romeded and omamented with fine nodes or ribs.

Septa lanceolate, lobes pointed and linguxform, saddles rounded. Tentral saddle long, narow, and bottle-shaped; ventral lobes long, tongueshapeed; three lateral lohes, similiar in shape, but decreasing in size toward the umbilicus.

This species is most nearly related to S. hyatti Smith, but has a wider umbilicus, more globose whorts, and retains the umbilical ribs to a greater size. It is quite possible that S. hyatti may be only a variety of S. hildrethi, but they will be kept separate until enough specimens are found to show the intergradation.

Hang" redescribed S. hildrethi and assigned to it the genus Ayathiceras, at the same time stating that it did not agree entirely with the type of Aguthiceras; but II ratt's genum sechistoceros was unknown to him, since it had not been figured and the type species had not been named.

Occurrence.-Upper Coal Measures ("Lower Barren"), near Cambridge, Guernsey Comnty, ()hio, and Cisco formation, (traham, Young Comnty, T'ex.

Specimens are in the U. S. National IIuseum from Graham, and Haug has rediscovered one in the Verneuil collection of the École des Mines, Paris, presenterl by Hildreth, from Cambridge, Ohio.

\section{Schistoceras hyatti Smitlı, sp. nov. \\ Pl. XX, figs. 1-8; Pl. XXI, figs. 10-13.}

188t. Schistoceras, sp. indet., A. Hyatt, Proe. Boston Soc. Nat. Hist., Vol. XXII, p. 336.

Form somewhat compressed laterally, with high helmet-shaped whorl, sloping sides, romuled venter, rounded mmbiliabl shoulders, and deep, open umbilicus, showing the immer whorls. 'The last whorl is indented to twofifths of its height by the preceding whorl. No ribs or constriction andur on the mature shell, but the surface is omamented with fine spiral strixe and fine sinuous cross strixe, giving a beatufully reticulated alprearances to the shell. In the adolescent stages there are strong umbilical ribs, which become obsolete at a diameter of about $15 \mathrm{~mm}$. The septa are goniatitic, but complex, divided into a large number of lobes and saddles. 'The siphonal saddle is long, notched, and bottle-shaped; the three lateral 
saddles are long, narow, and spatulate; the external lobe and the three lateral lobes are long, narrow, pointed, and tongue-shaped. On the umbilical shoulder is a fifth lobe, short and pointed, and on the dorsal side is a long, narrow, and pointed antisiphonal lobe, flanked on each side by a pair of lobes, of which the one nearest the dorsum is longe and the secomd short, like that on the umbilieal shoulder. There are thus fifteren lobes and fifteren saddles in all-one pair more than those of Aguthireras and two pairs more than those of Povalegoceras. It is prosiphonate, but it could not be ascertained at what stage the siphonal collars began to point forward.

The largest specimen seen had the following thimensions:

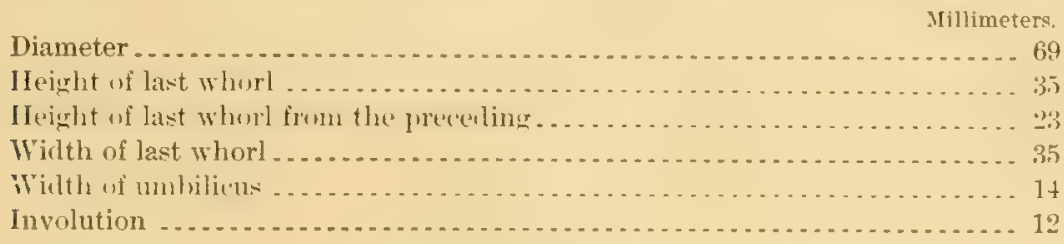

'This specimen was septate throughout, and the outer shell showed the impressions of the septa of inearly one-half a revolution in addition to this. The bouly rhamber would have alded at least three-quarters of a revolution more, so that the full diameter of this shell could not have been less tham $175 \mathrm{~mm}$.

The type of this species served Professor Hyatt as the type of his genus Schistoceras, and to his kindness the writer owes the use of the specimens. Since a specific name was never given to this form, the designation Schistoceras hyatti is appropriate.

This species is nearest to S. hildrethi Morton, but differs from it in being more compressed laterally, in the greater hesght of the whorl. in the slightly narower unbilicus, and in the fainter umbilical rils, which persist to a later stage in S. hildrethi.

Occurrence.-This species is at present known only from the Upper ('oal Measures, Ciseo fommation, of Graham, Tex. Specomens of it, incluling the type (PI. XX, fign. 5 and (i), are in the private collecetion oi the late Prof. Alphens Iratt, of ('ambridere. Mass.; in the Musenum of Comparative Zoology; and in the U. S. National Museum.

Gutogeny.-Since the individual development of this species shows its phylogeny in the plainest terms, it is given below, so far as could be ascertained. 
The smallest specimen seen (Pl. XXI, figs. 10i and 10b) had a diameter of $5.5 \mathrm{~mm}$., was evolute, broad and low-whorled, with caronate form, strong umbilieal ribs, and periodic constrictions. This ummistakably corresponded to ciustriocems. At one-half revolution in addition to the above the dimensions were:

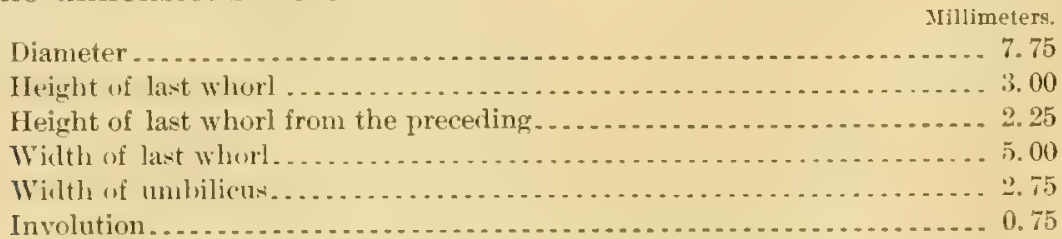

The gastrioceran ribs still persisted, but the whorl had become more highly arehed, and the septa were transitional from Crustrioceras to Paralegorras, while the form was still typical of crastrioceras. The addition of another half coil showed no change in the shell, except that the ribs were seen only on the umbilicus. At this stage the dimensions were:

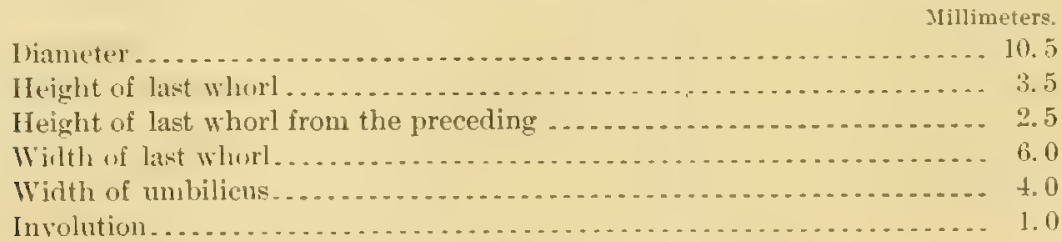

This is shown on Pl. XXI, figs. 11a, 11b, and 11c.

Another revolution showed the whorl highly arched and helmet-shaped, and the ribs hat disappeared; the resemblance to P'uralegoceras was now plain, but the septa showed an extra pair of lateral lobes just within the umbilical border. No speecies of I'aralegoceres has yet been observed with this extra pair of lobes, but such may yet be found, since only a few specimens of that genus are known. This stage (shown on Pl. XX, figs. 1 and 2, and Pl. XXI, fig. 12) gave the following dimensions:

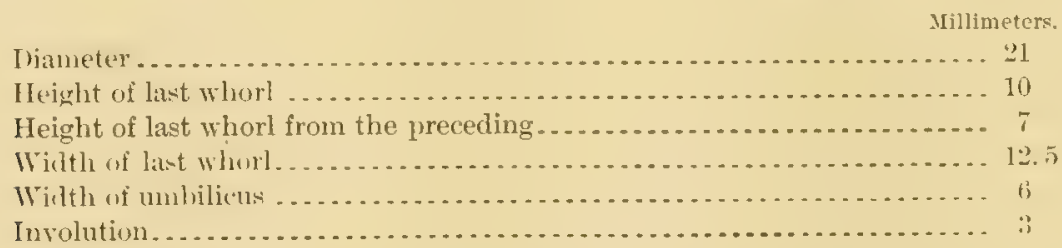

At diameter of $30 \mathrm{~mm}$, one-half revolution more than the preceding, the shell had taken on mature characters, the septa were typical of Schistoceras, and after this only an increase in size took place. This early mature stage is shown on $\mathrm{Pl}$. XX, fig. 3. 
A still larger specimen (one of Ilyatt's types) is shown on Pl. XX, figs. 5 and 6 , giving the following dimensions:

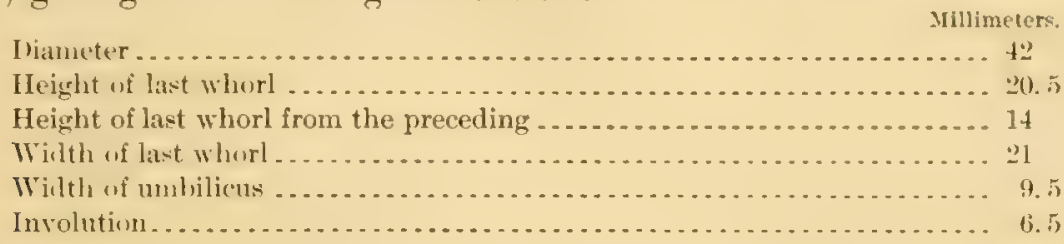

The largest specimen figured, diameter $69 \mathrm{~mm}$., showed about two-thirds of a revolution more than the last, but no change in septa, shape, or surface characters (PI. XX, figs. 7 and 8; Pl. XXI, fig. 13). Thus Srhistoceres clearly is derived from Ciastrioceras, through L'aradegweras, and undoubtedly belongs to the Glyphioceratidx, being the most complex member of that group.

\section{Schistoceras missouriense Miller and Faber.}

\section{Pl. VIII, fig. 1.}

1892. Goniatites missouriensis, Miller and Faber, Jour. Cincinnati Soc. Nat. Hist., Vol. XIV, p. 16t, Pl. VI, fig. 1.

Shell subglobose, involute, whorls highly arched, helmet-shaped, sides somewhat flattened, about twice as high as hroad, deeply embracing, showing but little of the inner whorls, and deeply indented by them. Umbilical shoulders abruyt and the umbilicus is deep and rather narrow, being hardly one-fourth of the total diameter. Surface apparently smooth, no constrictions being visible. 'The preservation of the cast does not permit the determination of the presence or absence of umbilical ribs.

Septa consisting of four lateral lanceolate lobes on each side, and probably a fifth on the umbilical border. The saddles are also like the lobes, but more constricted and club-shaped. The form and septa are mmistakably those of Schistoceras, and the species may very likely be identical with either s. layatti or s. hildrethi, but the figures and description of s'. missomiense do not permit this determination. It seems to be more compressed and to have a narrower umbilicus than either of the other species.

Oceurrence-Upper Coal Mleasures, Missumian stage, Brush ('reek, near Kansas City, Mo. Type in paleontologic collection, Walker Museum, University of Chicago. 


\section{Family AGANIDIDE.}

\section{Genus Agavides de Montfort.}

1854. Brancoceras, A. Hyatt (not Brancoceras Steinmann, 1881).

1895. Aganides, E. Haug, Etudes sur les Goniatites, p. 39.

1901. Aganides, F. Frech, Ueber devonische Ammoneen, p. 74.

Aganides rotatorius de Koninck.

Pl. XVI, fig. 19; Pl. XIX, figs. 12-14.

1842-184. Ammonites rotatorivs, L. G. de Koninck, Deser. anim. foss., p. 565, Pl. IsI, tig. 1.

1852-185t. Goniatites rotatorins, F. Roemer, Lethea Geognostica, 3d ed., Vol. I, Pt. 1I, p. 51, Pl. I, tig. 16.

1860. Goniatites rotatorius? James Hall, Thirteenth Rept. N. Y. State Cab. Nat. Hist., p. 101, figs. 15 and 16.

1860. Goniatites ixion, James Hall, Thirteenth Rept. N. Y. State Cab. Nat. Hist, p. 125, figs. 1-3.

1876. Goniatites rotatomine, James Hall, Illustr. Deronian Foss. Cephal., P'l. LXXIII, figs. 12-1t.

1876. Goniatites motatorius, F. Roemer, Lethara Geognostica, Pt. I, Lethan Paleozoica, Pl. XLVI, tigs. $12 \mathrm{a}, \mathrm{h}$.

1879. Goniatites ixion, James Hall, Pal. N. I., Vol. V., Pt. II, p. tit, PI. LXXIII, figs. 12-14; PI. LXXIV, fig. 12.

1850. Goniutites rotutomius. L. G. de Koninck, Faune cale. carbon. de la Belgique, Vol. 1, p. 246, Pl. XLVII, tig. 12.

1584. Brancoceras ixion, A. Hyatt, Proc. Boston Soc. Nat. Hist., Vol. XXII, p. 326.

1886. Branencercls ixion, James Hall, Fifth Ann. Rept. N. Y. State Geologist, Pl. XIII, tig. 3.

155s. Brancocems ixiom, C. E. Beecher, Pal. N. Y., Vol. V, Pt. II, Supplement, p. 40, Pl. CXXVIII, fig. 3.

1597. Brancoceras ixion, Foord and Crick, Catal. Foss. Ceph. Brit. Mus., Pt. III, p. $1+1$, fig. 62 .

1595. ? Brancoceras rotatorinu, M. Tzmetaer, Mém. Com. Géol., Vol. VIII, No. 4. p. 38, Pl. $\mathrm{V}, 19$.

1898. Aganides rotatorins, E. Haug, Études sur les Goniatites, p. 39, fig. 9e.

1901. Aganides ixion, F. Frech, Ueber deronische Ammoneen, p. 74, fig. 32c.

This species, which is very common at Rockford, Ind., but unknown anywhere else in America, is quite easily rocognizable. The following description is based on a number of specimens from Rockford.

Discoidal, compressed laterally, with sides sloping gently to the 


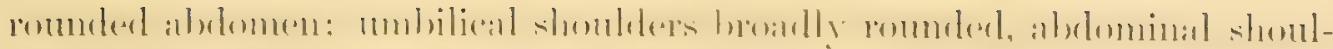
ders more abruptly. Greatest width of whorl at about one-fifth of height of whorl. Involution almost one-half of height of whorl. Umbilicus very narrow, almost closed, and not showing the immer coils. Surface smooth, no constrietions, ribs, or other ornamentation at maturity; but the writer has observed constrictions on a specimen of dimeter $13 \mathrm{~mm}$. Septa composed of a tongue-shaped ventral lobe, with a narrow, long, pointed lateral lobe on each side, narrow external saddle and broad lateral saddle. On the umbilicus there is a short broad lobe, and concealed by the involutiom there is a pointed spatulate antisiphomal lober resembling the external one, and on each side a narrow pointed lateral lobe. The septa figured here are from actual drawings from a specimen broken open to expose the interior. Number of septa to a revolution from 17 to 20.

James Hall at first considered Goniatites rotatorius and G. ixion to be irlentical, but atterwards changed his opinion. The differences on which he based the specific discrimination were the greater number of septa to a revolution in $G$. ixion and the greater lateral compression. But these very characters ald not andant in the specimens from Rockford, the number of septa to a revolution varying from 17 to 20 , and some shells are more compressed than others. The variation between individual specimens from Rockford is at leakt ats great as the differences between de Koninck's and IIall's types, and most paleontologists have always believed in the identity of the species.

The following are the dimensions of a Rockford specimen:

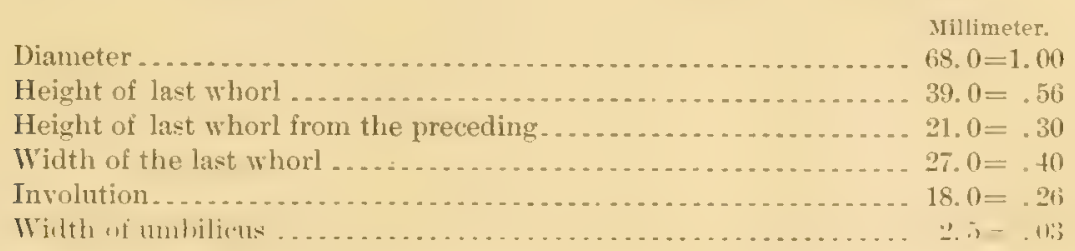

Compared with Ilall's figures and those of de Konnind this specimen might belong to either. In fant, instead of being more complesised than the Belgian form, it is rather broader.

Hyatt" chose Gonatites ixion Hall as the type of his genus Brancoceras, but this name had been preocenpied three yeals before by (x. Steimman for a genus of cretaceous ammonites. It hat, howerer, been itemonstrated 
that de Montfort ${ }^{n}$ used as the type of his genus Aganides the same species afterwards described by de Koninck as Goniatites rotatorius. Since this genus was described and figured by de Montfort, the laws of priority demand a recognition of it, in spite of the confusion made by later writers, for which he was not responsible.

Occurrence.-Aganides rotatorius occurs in America only in the goniatite beds of Rockford, Ind., in the Kinderhook stage. In Europe it is known only in the calcareous shales of Tournai, in lelgium, and in the same horizon in Ireland. Since the species occurs in the same horizon in two widely separated regions, it may be taken as a zone fossil and the horizon called the zone of Aganides rotatorius. Even if the species shonld not be absolutely identical, there are so many other identical forms in the two regions that the correlation is beyond doubt. The form described by M. Tzwetaev ${ }^{b}$ as Brancoceras rotatorium, from the Iloscow limestone of Rusia, pmbably belomger to amother species, although quite chosely related to the one under discussion.

Aganides discoidalis Smith, sp. nov.

PI. XXIV, figs. 5-7.

Shell discoidal, involute, laterally compressed, whorls deeply embracing, and deeply impresised by the inner volution. 'The height of the whorl is slightly more than one-half of the total diameter, and it is indented to nearly one-third of its height by the imner whorl. The width of the last whorl is nearly one-third of the total diameter of the shell and four-serenths of the height. The umbilicus is almost entirely closed. The sides of the whorl are flattened convex, curving gently to the narrow and rounded venter:

The surface (of the cast) is ornamented only with obscure sigmoidal strix of growth, with a broad, backward-pointing sinus.

The septa are of the usual Aganides type, with a tongue-shaped ventral lobe, deep and rather narrow, pointed lateral lobe, narrow extemal saddle, and broadly rounded lateral saddle.

This species is more compressed and discoidal than any other known species of this genus.

"Conchyliologie Systématique, Vol. I, p. 30. bIém. Com. Géol., Vol. VIII, p. 28. 
Occurene - In the Lower Carboniferous, Kinderhook stage, Choutean limestone, of I'ettis County, Ifo. 'The type is deposited in the paleontologie collection of the Walker Husem, University of Chicago, No. 8601. 'The writer's thanks are due to Dr. Stuart Weller for the use of the specimen, which is the only one known.

Aganides insond Miller and Gurley.

Pl. XVII, figs. 18-20.

1896. Goniatites jessicie, Miller and Gurley, Bull. Illinois State Mus. Nat. Hist. No. 11, p. 46, P’. V. figs. 18-20.

Shell discoidal, laterally compressed, involute. Whorls high, indented to one-half of the height by the preceding whorl; abdomen narrowly romded, sides flattemed. Volutions rapidly expanding, concealing all the inner whorls. Umbilical shoulders abruptly rounding; umbilicus closed. Brealth of whorl is equal to three-fourtho of the heignt and nearly one-half of the total diameter

Septa composed of a long, tongue-shaped, undivided, ventral lobe and a shorter and more rounded lateral. First lateral saddellomg and narrowly rounded; second lateral short and broadly rounded. Internal septa unknown.

Surface smooth, so far as known.

'This species is closely related to Aganides rotatorius, but has somewhat simpler septa, with longer ventral lobe, and rounded insteal of angular laterals. The form is also slightly more robust than that of Ayanides rotatorius.

Dr. J. MI. Clarke ${ }^{a}$ cites Aganides jessiece as a member of the genus Tornocevas, but its characters agree better with Aganides.

Occurrence.-Lower Carboniferous, Kinderhook stage, Sedalia, Mo.

Aganides propinques Winchell.

1862. Gomiatites propinques, A. Winchell, Am. Jour. Sci, 2d series, Vol. XXXIII, p. 365 .

1870. Goniatites propinques, A. Winchell, Proe. Am. Philos. Soc, Vol. XI, p. 259.

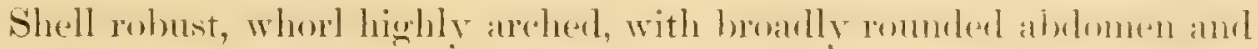
moderately convex sides. Umbilicus closed, not showing the interior 


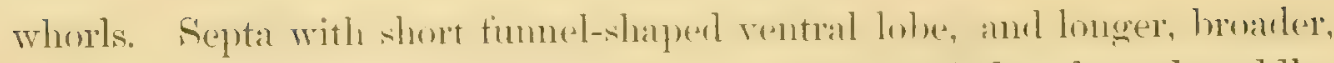
and rounded lateral lobe. Ventral saddles parabolic, lateral saddles rounded.

Occurrence-Lower Carboniferous, Kinderhook stage, Marshall group, Point aux Barques, Mich.

\section{Aganides romingert Winchell.}

1862. Goniatites romingeri, A. Winchell, Proe. Acad. Nat. Sci. Phila., 1862, p. 427.

Shell subglobose, whorl highly arched with regularly rounded venter and gently convex sides, ant but slight umbilieal depresion. C'mbilicus closed. Breadth of whorl equal to one-half of the total diameter of the shell.

Ventral lobe long, linguiform; clarate acute; lateral lobe long as ventral, narrow and sublinguiform. Ventral saddle obtuse, linguiform, unsymmetrie: lateral simlle deep, broal, extending nearly as far forward at the ventral.

This species resembles Aganides rotatorius de Koninck, but has narrower lateral lobe and is more robust on subglobose; the breadth of the whorl is one-half of the diameter, instear of only one-third, as in $A$. rotatorius.

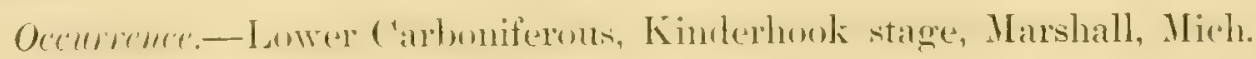

Aganides sciotoensis Miller and Faber.

Pl. VIII, figs. 2 and 3.

1592. Gomiatites sciotoensis, Miller and Faber, Jour. Cincinnati soc. Nat. Hist., Vol.

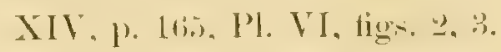

The following leseription is quoted from the paper by Miller and Faber:

Shell medium, or rather above medium size; somewhat lenticular in form, obtusely rounded on the dorsum [abdomen]. Umbilicus consisting of a shallow, funnel-shaped fossette, without exposing any of the rolutions. Volutions few, rapistly enlarging, the outer ones profoundly grooved for the reepetion of the inner ones, and depressed convex on the sides. The greatest transverse diameter is at the margin of the umbilieal fersette, and it is ahout two-thirds the dorwo-sentral diameter. Seven furrows radiate from the margin of the umbilicus on each side, curve gently forward at the superior lateral sides and then curve more abruptly backward across the dorsum [abdomen], as is shown in one specimen. Probably, if the specimen was 
perfectly preserved, it would show eight of these radiating furyows. Surface between the furrows showing traces of finer similarly sinuous lines. Body chamber and aperture unknown.

The sinmosities of the septa, as near as they can be determined from our specimen, may be described as follows: Dorsal [ventral] lobe lanceolate and pointed, superior lateral lobes longer than the dorsal, and pointed at the extrenities; dorsal [ventral] saddle sublinguiform, exadually narowing and rounded at the extrenity, lateral saddles similar in outline, the three inferior lobes short, with corresponding saddles.

Occurrence.Lower Carboniferons, Osage stage, Upper Waverly, Sciotoville, Ohio.

Aganides? shumardianus Winchell.

1562. Goniatites shumardiumus, A. Winchell, Am. Jour. Sei., 2d series, Vol. XXXIII, p. $36 t$.

1870. Goniatites shrmardianus, A. Winchell, Proc. Am. Philos. Soc., Vol. XI, p. 258.

Shell discoiclal, involute, laterally complesised. Wholl highly arohed, narrow, deeply embracing, but showing a portion of the imner whorls. Umbilicus open, width nearly one-fourth of the total dianeter. Height of whorl nearly one-half of the total diameter and once and a half times the height.

Septa of the usual Aganides type. Ventral lobe simple, tongue-shaped, pointed; lateral lobe wider and longer, also pointed; internal septa consisting of a long, slender antisiphonal lobe, with a parir of shorter laterals.

Occurrence.-Lower Carboniferous, Kinderhook stage, Lower Waverly group, Newark, Ohio.

Genus Muensteroceras Hyatt.

'The genus Muensteroceras was established by Hyatt," with Goniatites

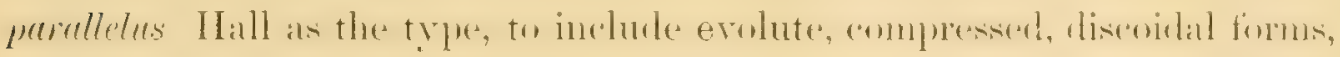
with highly arched whorls and moderately wide umbilicus. The septa are glyphioceran, and the most distinctive feature is the presence of an acute second lateral lobe outside of the umbilicus.

'The genus has usually been abandoned by later writers, being considered as a synonym of Goniatites de Haan or Glyphioceras IIyatt; indeed, it

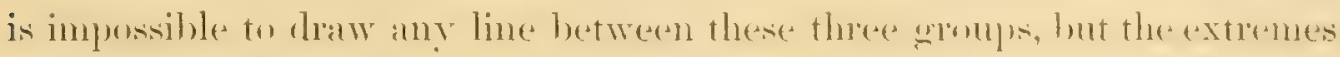
may be differentiated. 
E. Haug" proposes to retain the name, but as a subgenus under Pericychus Mojsisovics, on account of the sharp umbilical lobe. But in reality all the Glyphioceratidx have just such a lobe, only it is usually on the umbilicus, and the presence of such a lobe is hardly suthicenent justitiontion

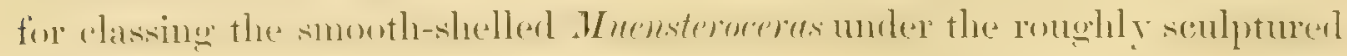
Pericychs.

The compressed form of this genus seems to indicate its origin in Aganides, by dividing the ventral lobe and widening the umbilicus.

Muensteroceras"? holmesi Swallow.

1860. Gonictites? hotmesi, G. C. Swallow, Trans. St. Louis Acad. Sci., Vol. I, p. $65 \%$.

Discoidal, involute, whorls ligh, abdomen sharply rounded, sides flattened. Whorls deeply embraring, incerasing rapilly in height. I'mbilicus narrow, funnel-shaped. Surface smooth, so far as known. Septa unknown.

Occurrence.-Lower Carboniferous, Kinderhook stage, Cooper County, Mo.

\section{Muensteroceras? indianense Miller.}

Pl. $Y$, figs. 3 and 4.

1891. Goniatites indianensis. S. A. Miller, Advance sheets Seventeenth Ann. Rept. Geol. Surr. Indiana, p. 90, Pl. XIX, figs. 2 and 3.

1892. Goniatites indianensis, S. A. Miller, Serenteenth Ann. Rept. Geol. Surr. Indiana, p. $700, \mathrm{Pl}$. XIX, figs. 2 and 3.

Shell discoidal, involute, deeply embracing, the inside whorl being entirely concealed by the outer. Whorl highly arched, laterally compressed, and indenterl to ome-half of its lexight hy the preceeding; sides flattened; abdomen rounded and rather broad. Umbilicus very narrow, not showing the imner whorls. Surface marked by four constrictions that run from the umbilicus nearly straight across the abdomen. Septa unknown.

Occurrence.-Lower Carboniferous, Kinderhook stage, Knobstone formation, Clark County, Ind. Type in the state Musem at Indiamapelis. 
MUensteroceras? Morganense Swallow.

1860. Goniatitex morgenensis, G. C. Swallow, Trans. St. Louim Acad. Ser., Vol. I, 1. $65 \%$.

Shell subglobose, whorl deeply embracing, with abdomen and sicles regularly rounded. Height of the whorl is one-half of the width and a little over one-fourth of the total diameter. Umbilicus narrow and deep, fumnel-shaped. Surface ornamented with three or four deep and broad constrictions to a revolution.

Occurrence-Lower Carboniferous, Kinderhook stage, Chouteau limestone, Missouri.

Muensteroceras osagense Swallow.

Pl. XXIV, figs. 8-12.

1860. Goniatites usengensiv, G. C. Swallow, Trans. St. Louis Acad. Sci., Vol. I, p. 659.

Shell discoidal, moderately convex, with broadly rounded abdomen and somewhit thattened sides. Whorls deeply embracing and deephy indented by the inner volutions. The umbilicus is narrow and fumelshaped, exposing only the umbilical shoulders of the inner whorls. The height of the whorl is one-half of the total cliameter of the shell, and the width is equal to the height. The last whorl is indented to one-half its height by the preceding volution. The umbilicus is one-sixth of the total diameter.

The surface of the cast is marked, on the last revolution, with six deeply incised, sinnous constrictions, showing a narew backward-pointing sinus.

The septa have a divided ventral lobe and a moderately deep lateral. The lobes are all pointed, and the saddles are romderl. Swallow comprod this species with Gilyphioneres mironotum Phillips, but the relationship is not elose.

Occurrence-Lower Carboniferous, Kinderhook stage, Cooper, Moniteau, and Pettis counties, Mo. The specimen figured in this paper is depositerl in the paleontologic collection of the Walker Musemm, Inirersity of Chicago ( $\mathrm{No} .8602)$; it was found in the ('houtean limestone of Pettis County, Mo., the more exact locality being' unknown. 'The writer's thanks are due Dr. Stuart Weller for the use of the specimen. 
Muensteroceras oweni Hall.

Pl. XIX, figs. 3-8.

1860. Goniatites oveni,.J. IIall, Thirteenth Rept. New York State Cab. Nat. Hist., p. 100 , figs. $11,12$.

1862. Goniatites oweni, A. Winchell, Am. Jour. Sci., 2d series, Vol. XXXIII, p. $36 t$. 1879. Grmentites oweni, J. Hall, Pal. N. Y., Vol. V, Pt. II, p. tī', Pl. LXXIII, figs. 3-8, Pl. LXXIV, fig. 9.

18s1. Goniatites oweni, C. A. White, Second Aun. Rept. Geol. Surv. Indiana, p. 514, Pl. VII, figs. 3 and 4.

18st. Thuensternceras oweni, A. Hyatt, Proc. Boston Soc. Nat. Hist., Vol. XXII, p. $32 t^{\circ}$.

1884. Ifuensteroceres whitei, A. Hyatt, Proc. Boston Soc. Nat. Hist., Vol. XXII, p. 326.

1856. Gomiatites meeni, J. Hall, Fifth Ann. Rept. N. Y. State Geologist, PI. XIII, figs. 4,7 .

18s8. Goniatites ourni, C. E. Beecher, Pal. N. Y., Vol. V, Pt. II, Supplement, p. 40, PI. CXXVIII, figs. 47 .

189\%. Glyphioceras oweni, Foord and Crick, Catal. Foss. Ceph. Brit. Mus., Pt. III, p. 188 , fig. 89.

1895. Pericychus (Muensteroceras) oweni, E. Haug, Études sur les Goniatites, p. 102, Pl. I, fig. 43.

1901. Glyphioceras oweni, F. Frech, Ueber devonische Ammoneen, p. 84, fig. 37 a.

Shell discoidal, laterally compressed, abdomen rounded, sides some-

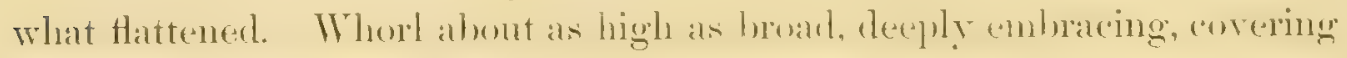

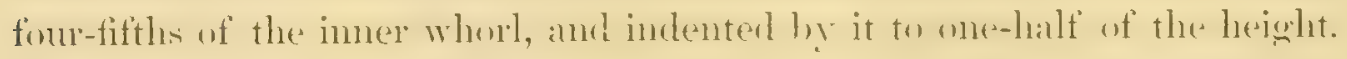

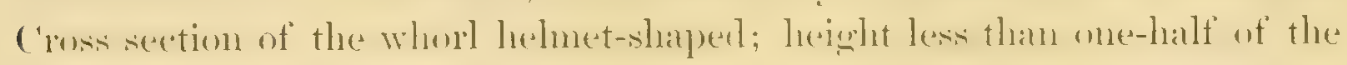
total diameter; greatest breadth a short distance above the umbilical shoulders, which are abrupt and angular. Umbilicus moderately wide, varying in width from one-fourth to more than one-third of the total diameter, and exposing the angular shoulders of all the imer whorls. 'The immer whorls are very globose, the breadth at diameter of $10 \mathrm{~mm}$. being: nearly equal to the diameter, and the umbilicus is proportionally narrower. Surface of the shell, which is rarely seen, marked by fine transverse strix. Surface of cast marked by three or four wide and shallow constrictions, begimning on the umbilical shoulders and betnding batek wat over the abdomen in a broad curve. These constrictions are variable in interval and become much more frequent on old shells.

Septa close together, consisting of a long, narrow siphonal lobe, divided by a short, notched siphonal saddle: a sharply pointed, shallow 


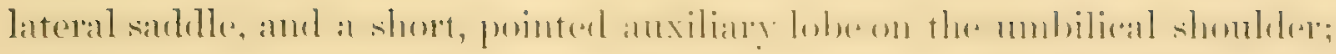
the superior lateral saddle is deep, and the second is broad and shallow. The internal septa consist of a short, pointed antisiphonal lobe and a pair of similar laterals; the antisiphonal saddle is numow, and the interior lateral is broadly rounded.

This species is most nearly related to ILuensteraceras (Glyphiocerus)

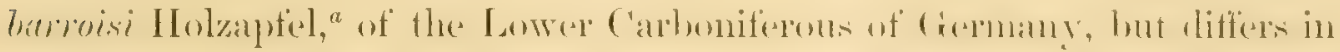
the backward-pointing curve of the constrictions, greater width of the umbilicus, more depressed whorls, and greater approximation of the septa.

The species is exceedingly variable in width of umbilicus, breadth of whorls, and involution, so that it is possible that there are several distinct but nearly related species included in this one. Prof. A. Hyatt ${ }^{b}$ proposed the name Muensteroceras whitei for a specimen figured by Dr. C. A. White under the name of Goniatites oweni Hall. But since White's figure seems to be merely a copy of Hall's illustration of the type specimen, this name becomes merely a synonym. In a large number of specimens examined by the writer there was no constaney of characters that might justify a separation into species or even varieties.

Occurrence.-Muensteroceras oweni is common in the Lower Carboniferous, Kinderhook stage, woniatite limestone of liorkford, Ind., ansoriated with II. parallelum Hall, Prolecanites lyoni Meek and Worthen, Aganides

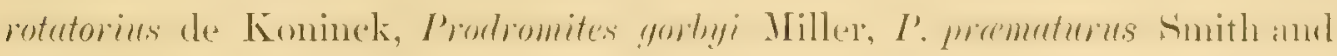
Weller. All these are of distinctly European type, except Prodromites, which is of unknown antecedents. M. oweni has also been cited by Winchell from the Kinderhook stage, Marshall group, of Michigan, and in somewhat the same association as at Rockford, Ind. 'The illustrations on Pl. XIX, figs. 3-8, are copied from Hall's Paleontology of New York, Vol. V, Pt. II, Pl. LXXIII, figs. 3-8.

\section{Muensteroceras parallelum Hall. \\ Pl. XVI, fig. 3; Pl. XIX, figs. 1, 2.}

1860. Goniatites oweni var. parallela, J. Hall, Thirteenth Rept. New York State Cab. Nat. Hist., p. 100, figs. 1\%, 14.

"Pal. Abhandl., Vol. V, p. 30, pl. 1, fige. 10, 10a-b.

broc. Boston Soc. Nat. Hist., Vol. XXII, p. 32t.

$c$ Second Ann. Rept. Geol. Surv. Indiana, Pl. VII, tigs. 3 and 4. 
1862. Goniatites oweni var. parallela, A. Winchell, Am. Jour. Sci., 2d series, Vol. XXXIII, p. 364

1879. Goniutites oreni vax. pumblele, J. Hall, Pal. N. Y., Vol. V, Pt. II, p. 4i3, Pl. LXXIII, figs. 1 and 2; PI. LXXIV, fig. 10.

185t.' Muensteroceres parellelum, A. Hyatt, Proc. Boston Soc. Nat. Hist., Vol. XXII. 1). 327 .

1897. Glyphioceras paralletum, Foord and Crick, Catal. Foss. Ceph. Brit. Mus., Pt. III, p. 189, tig. 90.

Shell discoidal involute, laterally compressed, deeply embracing, concealing nearly all of the immer whorls. Abrlomen highly arched, sides

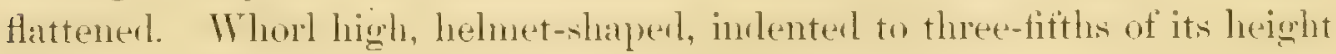
by the inner volution, width fomr-fifths of its height, which is more than one-half of the total diameter. Greatest breadth at a point even with the top of the inner volution. Umbilicus narrow, less than one-fifth of the total diameter; umbilical shoulders abrupt and angular.

Surface marked by about four backward-curving constrictions.

Septa similar to those of $\boldsymbol{M}$. oweni, but closer together:

This species is most nearly related to $\lambda L$. oveni, but differs from it in the meater lateral compression, the higher whorls, the narrower umbilicus, wreater involution, and greater aploximation of the septa. In the young shell the form is more globose, as the writer has seen on a specimen $10 \mathrm{~mm}$. in diameter, broken out of a larege shell. In this small specinen the mmbilicus was still narrow, and the sides still somewhat complessed, so that even at this stage it could be distinguished from the voung of Murnsteroceres anemi.

This young specinnen had the following dimensions as companed with the young of ALuensteroceras oweni:

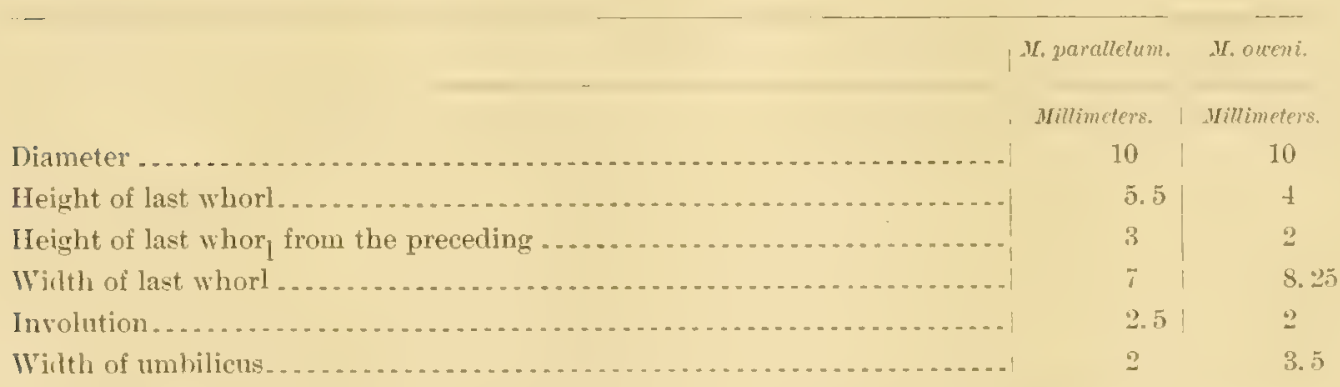

The septa at this young stage are still of the glyphioceran type, and very similar to those of the adult except that they are less approximate, and the ventral lobe is less deeply divided by the siphonal saddle. A 


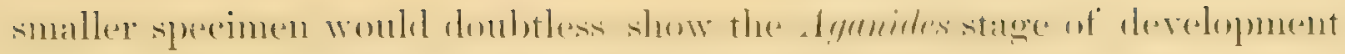
with undivided ventral lobe, but the writer did not succeed in breaking out any smaller shell than diameter of $10 \mathrm{~mm}$.

Occurrence-Lower Carboniferous, Kinderhook stage, goniatite beds of liockford, Indiana. Winchell has aiso cited this spereites from the Kinderhook, Marshall group, of Michigau.

The septa shown on Pl. XVI, fig. 3, are drawn from a specimen in the writer's collection. The illustration on P'I. XIX, figs. 1 and 2, are copied from Hall's Palicontology of New York, Vol. V, Pt. II, Pl. LXXII, figs. 1 and 2.

Genus Gonioloboceras Hyatt.

Gonioloboceras? aldei Winchell.

1562. Goniutites allei, A. Winchell, Am. Jour. Sci., 2d series, Vol. XXXIII, p. 363. 1870. Gomiutites allei, A. Winehell, Proc. Am. Philos. Soc, Vol. XI, p. 258.

18\%0. Goniatites allei, A. Winchell, Sketches of Creation, p. 116, fig. 50.

Shell discoidal, laterally compressed, involute. Abdomen highly arehed and narrowly rounderl, sides Hattened. Limbiliens alosed, not showing any of the inner whorls. Whorl increasing rapidly in height and indented to one-half of its height by the preceding volution. Surface ornat mented with fine spiral lines, and with four constrictions to a revolution. Septa consisting of a shallow, hroad, pointed extemal lobe, divided by a broad rentral sadule, which is probably notched: a hroarler and pointed lateral lobe. The first and second lateral sardles are somewhat similar to the lateral lobe, but rather rounded; internal septa consisting of a pointed dorsal, and pair of similar laterals. This form is doubtfully referred to cominloboreress, but Winchell's description is inadeguate, and his figure in Sketches of Creation is hardly more than a sketch.

ocenrence-Iswer Carboniferous, Kinderhook stage, Marshall group, ITarshall, Mich.

\section{Gonioloboceras goniolobum Meek.}

Pl. IV, figs. 1-3.

1877. Goniatites goniolobus, F. B. Meek, U. S. Geol. Expl. Fortieth Parallel, Vol. IV, Pt. I, p. 98, Pl. IX, figs. 5, 5a, 5b.

Meek's Goniatites goniolobus was taken by Hyatt ${ }^{\prime}$ as the type of the

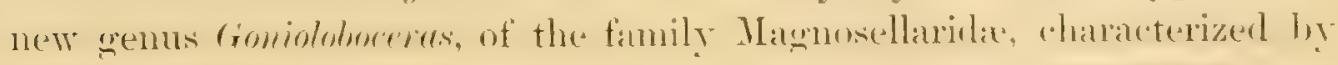


the flattened sides, narrow abdomen, and the extremely angular lobes. The specimen came from an unknown horizon and locality of the Carboniferous of New Mexico, presumably from the Coal Measures. 'The writer, however, considers this genus as a member of the Glyphioceratidx, from observations made on the young of another species. It probably came from Aganides though Muensteroceras, and in tum gave rise to Dimorphoceras by a further division of the external lobes. It seems, however, quite

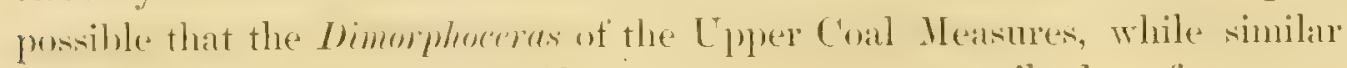
to that of the Lower. Carboniferous, may not necessarily be of common origin with it.

Occurrence-Carboniferous, Coal Measures.? New Mexico, locality unknown.

\section{Gonioloboceras? Limatum Miller and Faber.}

Pl. VIII, figs. 8 and 9.

1892. Gomiutites limutus, Niller and Faber, Jour. Cincinnati Soc. Nat. Hist., Vol. XIV, p. 166, Pl. VI, tigs. 8 and 9.

The following description is quoted from Miller and Faber's paper:

Shell small, elegant, thin, discoidal, rapidly expanding in circumference, with rery slight increase in thickness; sides flat, and dorsum [abdomen] narrowly rounded. Umbilicus small, abrupt, exposing very little of the inner whorls. Volutions expanding dorso-ventrally with very little increase transversely; the outer ones fully embracing the inner ones, flattened on the sides from the umbilicus to the middle of the superior lateral saddles, from which a flat depression extends to the margin of the rounded dorsum [abdomen].

The septa are of the Ayanides type; rentral lobe linguiform, narrow, twice as long as wide; lateral lobe broad, shallow, and pointed; ventral saddle broader than the ventral lobe and of the same length; superior lateral saddle broader than the rentral saddle, narrow, and rounded at the extremity; second lateral saddle broadly rounded. Internal septa consisting of an antisiphonal lobe and a pair of similar laterals.

This form is evidently transitional from Aganides to Gonioloboceras; it is a typical Ayanides on the younger part of the shell, but the ventral lobe seems to be divided on the last whorl.

Occurrence-Lower Carboniferous, St. Louis stage, Crab Orchard,

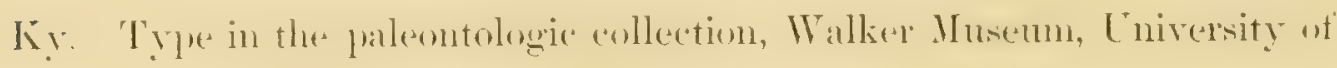
Chicago. 


\section{Goxioloioceisas Welleis Smith, sp. noy.}

$$
\text { I'l. XX, figs. 9-11; P'. XXI, figs. 1-6. }
$$

This species was at first thought by the writer to be identical with G. goniolobum Ileek, but it has the sides somewhat more flattened, is more compressed laterally, and at maturity has the venter narrow, angular, and slightly furrowed; also the rentral saddle is not notched, but has a tongueshaped forward extension. In G. goniolobum the siphonal saddle is narow, in G. velleri it is broad and rounded. These differences may be due to individual variation or to incorrect drawing of Meek's type; but none of the specimens before the writer varied in these respects.

The adolescent stage (figured on P'l. XX, figs. 9-11) of a young shell, broken ont of a mature specimen from Graham, 'T'ex, shows the characters of Muensteroceras, and proves that the genus is derived from a typical member of the Glyphioceratidx, for the shape of the shell, the wide umbilicus, flattened sides, broadly monded abdomen, anstrictions, and the septa all agree with that genus.

The shell is smooth, compressed, with flattened sides and narrow romeded venter at early maturity; angular and slightly furrowed at at later stage. The umbilicus is very narrow, showing none of the innel whorls; the whorl is involute, deeply embracing, indented to more than one-third of its height hy the preceding whorl. Surtace smooth, deroid of constrictions, ribs, or other ornaments. The septa are angular and sinuous, showing the

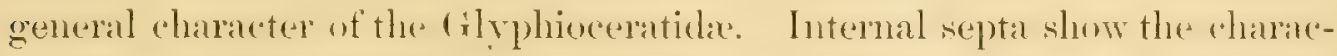
teristic sharp antisiphomal lober and the tomerue-shaped intermal lateral on each side, as do all typical members of the Glyphioceratide.

Occurrence.-The first specimen of this species was seen by the writer in the paleontologic collection of the Walker Museum, University of

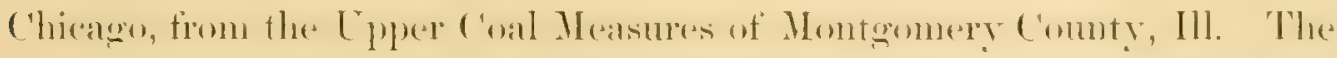
only other specimens known are from the Upper Coal Measures, Cisco formation, of Graham, Young County, 'l'ex., where they were collected by A. B. Gant. Other specimens are in the private collection of the late Prof. Alpheus Hyatt, in the U.S. National Museum, and in the private collection of the writer, obtained on a recent visit to Graham. The genus Willeroceras of IIyatt is probably only the young of Gonioloboceras, but not enough specimens are known at present to determine this. 
'T'he specific name is given in honor of Dr. Stuart Weller, of the University of Chicago.

The type is figured on Pl. XXI, figs. 1 and 2. It was presented to the writer by Dr. Gant, and was collected from the Cisco formation, Upper Coal Measures, of Graham, Tex. It is in the writer's collection in the Leland Stanford Junior University, California.

\section{Genus Dimorphoceras Hratt.}

The type of this genus " was Goniatites gilbertsoni Phillips. All the species are rather compressed, involute, smooth shells, with narow umbilicus. The surface is ornamented only by the curved cross strix of growth. The ventral lobe is divided by a deep, notched, siphonal saddle, and the two lobes thus formed are divided a second time, giving a pair of short, narrow ventral lobes on each side of the abdomen. On the middle of the flank there is a deeper, pointed lateral lobe, and another on the umbilical shoulder. Inside, concealed by the involution, is a tongueshaped antisiphonal lohe, flanked on each side by a pointed lateral. Thus there are three intemal lobes, six extemal, and a pair on the umbilical shoulders, eleven in all. 'This is the same number as in Paralegoceras, but of different character. In Puralegoceras the multiplication of lobes takes place within the umbilical border, but in Limonphores the intemal number is normal and the extra pair of lobes is formed by division of the ventral lobes. This genus probably comes from Goniolobocerts, by secondary division of the external lobes.

Occurrence.-Dimorphoceras occurs in Europe in the Lower Carboniferous and the Coal Measures; in America it is known only from the Upper Coal Ileasures, Cisco formation, near Graham, Young County, Tex., the sperinem described in this palper being the only one known to be in any collection.

Dimorphoceras texanum Smith, sp. nov.

PI. XX, figs. 12-15.

Shell discoidal, compressed, involute, with narrow umbilicus, flattened sides, and greatest breadth at the umbilical shoulders. Venter narrow, flattened, angular, and slightly furrowed at naturity, but rounded in 
youth. The surface is free from sculpture and ormamented only with lines of growth.

The septa consist of a ventral lobe, divided by a broad, notehed siphonal saddle, and the pair of external lobes thus formed are dividerl a second time by a narrow, spatulate saddle; a broad, pointed lateral lobe, and another somewhat similar on the umbilical shoulder. Inside the involution there is a long, narrow, tongue-shaped antisiphonal lobe, flanked by a pair of shorter laterals. There are thus six external lobes, a pair on the umbilical shonders, aud three internal, eleven in all. This is the number possessed by Paralegoceras, but in that genus the division of lobes takes place on the dorsal side, inside the umbilicus, while in Dimorphoceras it takes place on the ventral side.

Dimensions of specimen figured.

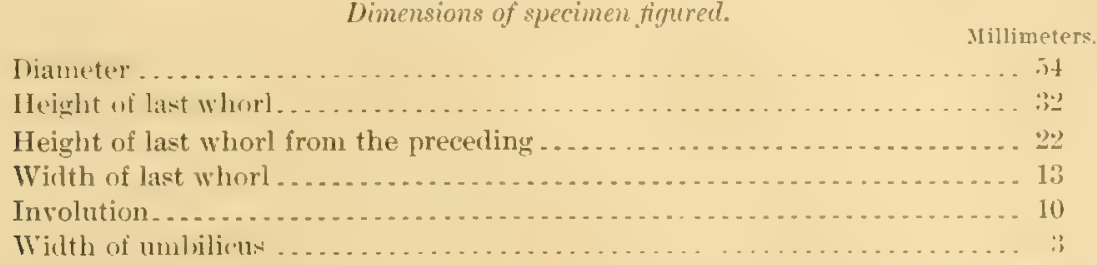

This specimen was septate throughout, and if the body chamber ahded three-fourths of a volution, the complete diameter must lave been not less than $100^{\circ} \mathrm{mm}$.

Occurrence-Upper Coal Measures, Cisco formation, west of Mars Hill, near Graham, Young County, Tex, collected by A. B. Gant. The type is in the private collection of the late Prot. Alpheus Hratt, of Cambridge, Mass., to whose kindness the writer owes the use of the specimen.

\section{Genus Milleroceras？ Hyatt.}

Milleroceras Parrishi Miller and Gurley.

Pl. XVI, figs. 6-8.

1894. Goniatites sp. indet., C. R. Keyes, Geol. Survey Missouri, Vol. V, Pt. VII, PI. LV, fig. 1.

1896. Goniatites parrishi, Miller and Gurley, Bull. Illinois State Mus. Nat. Hist. No. 11, p. 36, I'l. IV, figs. 6-8.

1900. Hilleroceras parrishi, A. Hyatt, Cephalopoda, 1900, p. 550.

This species is the type of Hyatt's supposedly new genus Milleroceras, which he assigned to the Primordialida. The writer has examined the

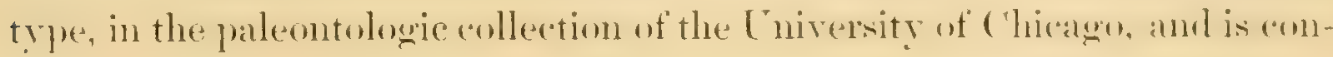


vinced that it is merely the young of some member of the Glyphioceratide, probably either Gonioloboceras or Dimorphoceras. At any rate, the oceurence of the l'rimordialida in the I"pper Coal Measures is extremely unlikely, since that family is not known above the Devonian.

Occurrence-Upper Coal Measures, Kansas City, Mo.

$$
\text { Supertamily AROFSTIDA. }
$$

The ontogeny of but few of the Paleozoic forms assigned to the Arcestidar has been investigaterl, but Triassice species show in their adolesent stageses stromer resemblances to some of these, and (nable us to piece out their history.

The genera thomelit to represent the Arcestidae in the American Carbon-

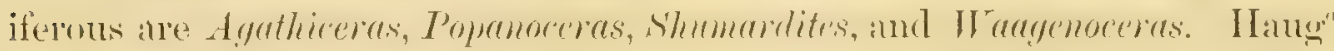
has placed the first with the (tlyphioneratidas, and the serend with the Agoniatitida, leaving only Irangenorems as an undoubted representative of the Areestidae. This classification, howerer, is based purely on resemblances of adults, hence the writer has prefermed to follow Kampinsky, whose clasisification seems to agree more elosely with the facts brought out by the writer's investigation of the ontogeny of shumarlites, ficestes, and I'arapopanoceres Also the supposed species of Alyathireres, on which IIang's ophinion was based, is shown in the present paper to be a Schistoceras, and to belong

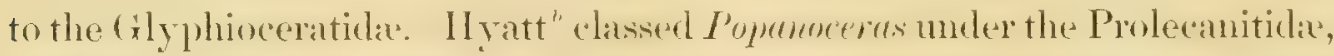
with which group, as now understomel, it has manifestly no kinship. In his most reecent work II yatt" elassed I'openoweses in the family P'opanoceratidax along with Waagenoceras under the superfamily Arcestida.

In the Paleozoic Arcestide may be found at least two families with (hamacteristios in common that point to a common origin in the gastrioceran branch of the Glyphioceratidat, but with sufticeient differences to make probahle their derivation from different genera. Agathiceres, Adrianites, Popanoceras, Stacheoceras, and possibly Doryceras and Clinolobus all seem to be nearly related, and form a transition from the goniatitic Paralegoceras, through Alyathiceres, into genuine ammonites characterized by a trianidian development of the lobes. Hyatt has classed some of these genera under the group Popanoceratidix, which term is here used for this branch of the Arcestes-like forms.

${ }^{a}$ Etudes sur les Goniatites. ${ }^{b}$ Proc. Boston Soc. Nat. Hist., Vol. XXiI, p. 337. c Cephalopoda, p. 564. 


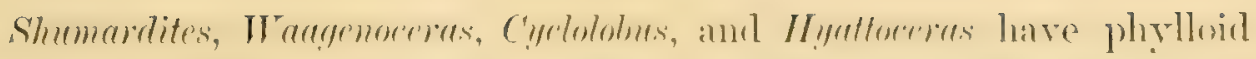

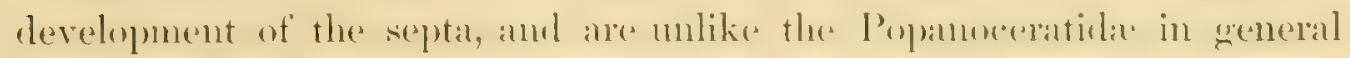
chancters. K. A. von 'Zittel has classed some of these under the group ('velolobidar, which term is here retained as a fimily name for the Pallenzoic Arcestide with phylloid septa. 'The writer has observed in Shumar-

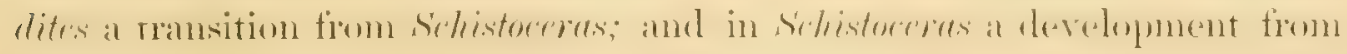

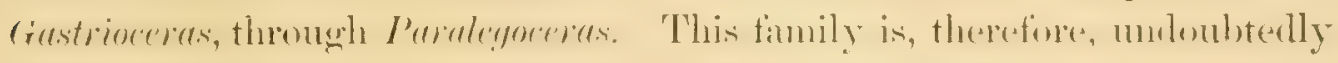
derived from the gastrioceran branch of the Glyphioceratidx.

It is not possible, at present, to determine which of these families gave rise to the typical Arcestidre of the Trias, but the writer is inclined to the opinion that they came from the Cyclolobidx. 'The young stages of some Arcestes, however, show a strong resemblance to Adrianites, and both branches may be represented among them. Popanoceras, at any rate, still persisted until the middle 'Trias, with its chatracters little chamged, and may very well have wiven rise to a number of the genera commonly asisigned to Arcestes; this genus then would prove to be polyphyletic, and the sub genera into which it is divided would be given full generic rank.

The oldest of the Arcestidx, Popanoceras, has been found in the Middle Coal Measures, while Agathiceres, fiom which it is supposed to have been derived, is not known below the Upper Coal Measures. Agathicreas probably came from either Itadegoceres or Schistoreres, although the latter genus is not known at present to antedate it. But in Gastrioceras, Paralegaceras, schistoceras, shumarlites, Wrangenoceras we have al line of descent in which the geologie serquence, the transitions of the adult forms, and the individual ontogeny are all in perfect accord.

Since these Arcestidx are so well represented in the American Coal Measures, and are unknown elsewhere in the world below the Permian, they may be considerest as having originated in the Anerican recoion, and to have reached the rest of the world afterwards by migration.

Suess ${ }^{a}$ years ago formulated the hypothesis that the appearance of ammonites in the Ifexliteranean region at the beximning of Permian time marked an invasion of tropical forms from a supposed southern region. But the evidence brought forward in this paper shows clearly that the Arcestidxe need not have come from this supposed southern region, especially as we do not know anywhere in southern Paleozone deponits members 
of the Arcestida older than the Permian. Karpinsky" has shown that Medlicottia came directly from Pronorites, which is known in the Lower Carboniferous in both Europe and America. Thus the whole argument for a Permian migration from the Southern to the Northern Hemisphere falls to the ground.

The Paleozoic Cyclolobidx are known at present only in Texas, the Ieditervantan region, and in India. The Paleozoic Popanoceratide are known in these regions (with the exception of India), in the Ural Ilomntains in Russia, and one form, Aguthereves? micromphalum Morris, has been described from the Permian of Australia. But since both stocks appear in the Coal Ifeasures of Ameriea, and sine their ancestor, Purulegoreras, is known, in America, even in the Lower Carboniferous, both Cyclolobidx and Popanoceratida probably originated in the American waters and reached the rest of the world by migration at a later date. 'Their' differences of distribution in not, therefore, argue for climatic differences, but rather for greater hardilood of the l'opanoreratidax, which is borne out by the fact not only that they migrated as far from their point of origin as Russia on the one side and Australia on the other, but also that they persisted with but little change as late as the Middle Trias.

\section{Family POPANOCERATIDE.}

Genus Agathiceras Gemmellaro.

To the writer it seems wiser to keep Agathiceras separate from Adrianites, because the former is a more primitive type, even though there should be a perfect gradation between the two groups. Two American species of Schistoceras have been placed under Agathiceras; but those species differ from the type in having an extra pair of lateral lobes, and in not possessing the mustally strong development of the spiral lines, so characteristic of all species of Aguthicens. Another chamcteristic worth noting is that in Sthistoceras the lobes and saddles are long, pointed, and tongue-shaped, while in Ayathiceras they are short and spatulate. 
Agathiceras ciscoense Smith, sponov.

PI. XXI, figs. 17-19.

In the U. S. National IIuseum is deposited a specimen that meets all the requirements of the genus Agathiceres, the type of A. ciscoense sp. nov.

'This species is rather high-whorled, with rounded venter and flattened sides. The umbilicus is closed, and thus narower than in Paralegoceras

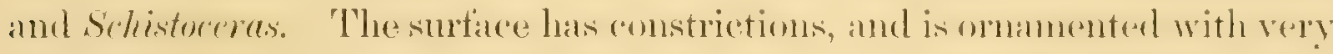
strong spiral lines or ridges narrower than the intermediate furrows, as in European species of this genus. It, however, lacks the network of fine crosis lines of growth seen on schistoceres, and this difference may turn wht to be one of the criteria for the separation of the two genera.

The septa resemble those of bchistocems in number and general shape, but the lobes are rounded and not pointed. The siphonal saddle is notched. The four lateral saddles are rounded and entire, spatulate in shape, while the four extermal lobes are constricted and tomgue shaped.

This speciess resembles A. suessi Gemmellaro, of the P'ermian Fusulina limestone of Sicily, hut is slightly more compressed. 'This difference might not be more than individual if the association and range of the two were the same, but in view of the great separation and differences in faunal association it must be specific. A. uralicum occurs in the Upper Carboniferous limestone of the Ural Mountains, but does not resemble A. riscornse except in a general way.

Occurence-In the Upper Coal Measures, Cisco fomation, of Graham, Young County, Tex., associated with a typical Missourian famal Only a single specimen is known, deposited in the U. S. National Iusemm (No. 27199), collected by A. B. Gant.

bimensions of the specimen figured:

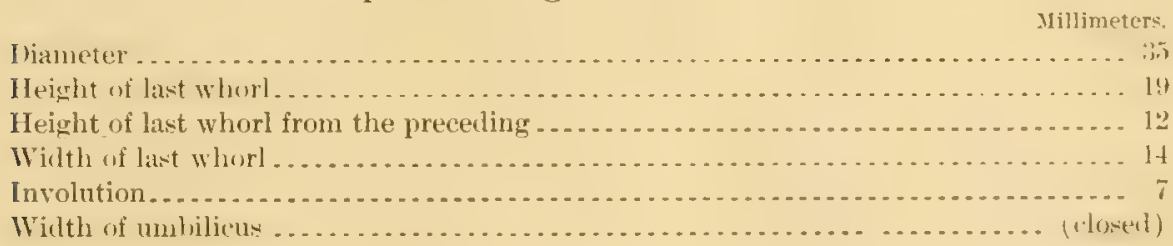




\section{Genus Popanoceras Hyatt.}

This genus was established by Hyatt" to include involute, slightly compressed forms, with ahmost closed umbilicus and little seulpture. The saddles are rounded and entire; the exterual lobes, four or more in number on each side, are serrated, either bifid or trifid.

The type is Goniatites lingianus M. V. K., from the Artinsk beds of the Permian of the Ural MIountains. Several Triassic species have usually been classed under this group, but they are now placed under Parapopa-

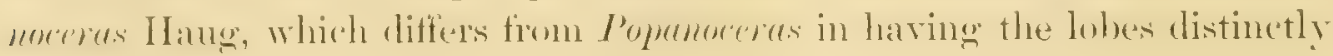
serrated, with the denticulations encroaching on the saddles.

\section{Popanoceras ganti Smith, sp. nov.}

Pl. XXT, figs. 14-16.

This species is involute, with broadly rounded venter and slightly flattened sides, very involute and close-coiled, with umbilicus almost closed. The shell has fine cross lines of growth, slightly curved forward, and five sharply defined, baekwarl-corving constrietions on the last whorl, parallel to the cross strix. The septa are typical of Popanoceras, and are divided into numerous lobes and saddles. The extemal lobes are five in number on each side, and the internal are five on each side, with an undivided antisiphonal. The saddles are all rounded and entire, the lobes all denticulate. The external lobe is short and hifid, the lateral lobes all trificl. The siphomal sirddle is notcheal by a shallow indentation. 'The shape and number of the internal lobes could be seen, but it could not be ascertained whether or not they are denticulate.

Affinities.-Popanocerus ganti resembles slightly I'. purkeri Heilprin, but differs from it in being somewhat more compresied laterally in the shorter lobes and saddles, and in having the first lateral lobe trifid instead of bifid. It is thus a more specialized form than $P$. parkeri, but simpler than $P$. valcotti White of the Permian, from which form it differs in the smaller number and greater simplicity of its lobes. It may possibly be an intermediate form in the genetic series of $P$. parkeri and $I^{\prime}$. walcotti. This 
species has only a generic resemblance to the forms from the Ural Iomatains and the Fusulina limestones of Sicily, all of which leelonge to thet Permian, and are therefore usually more complex in development.

Dimensions of the figured specimen:

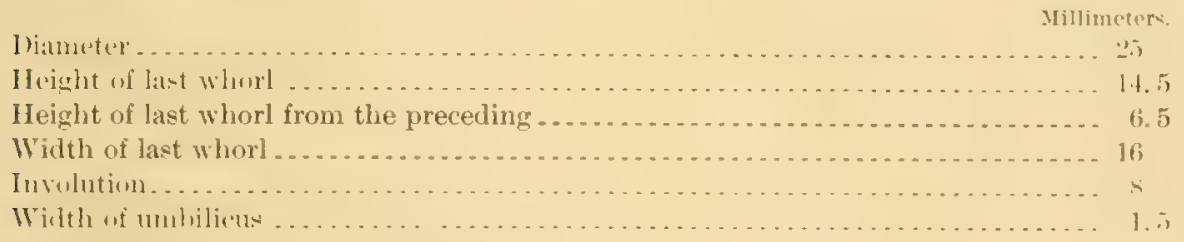

This form is more globose and primitive than most of the described species of this genus, and it is next to the oldest known member of Popanoceras, the oldest being P. parkeri of the Middle Coal Measures.

Occurrence-Upper Coal Measures, Cisco formation, Graham, Young County, 'T'ex., collected by A. B. Gant. 'Type No. 27202 in the U. S. National Museum.

\section{Popanoceras parkeri Heilprin.}

Pl. XVI, fig. 21.

188t. Ammonites purtieri, A. Heilprin, Proc. Acad. Nat. Sci. Phila., 188t, p. 53, figs. 1 and 2.

1889. Pupanocerts parkeri, A. Karpinsky, Ammoneen der Artinsk-Stufe, p. 75.

Shell subghobose involute, abdomen rounded, sides someswat flattened. whorls high and deeply embracing.

Septa divided into numerous lobes and saddles; the lobes are all digitate, the saddles entire and rounded, exeret the siphonal saddle, which is motehed. Ventral lobe long and bifid: first lateral lobe like the ventral, but shorter and broader; second lateral tripartite, and broader than the first; third lateral on the umbilical shoulders.

Occurence-Widdle Coal Measures, Strawn formation, Wise County, Tex. F. Frech ${ }^{a}$ refers to these beds as Permian, but they are some distance below the Cisco formation, and associated not with a Permian fama, but with undoubted Coal Measures species. The Strawn formation lies several thousand feet below the Wichita Permian. 


\section{Popanoceras walcotit White.}

Pl. XXII, figs. 9-11.

1559. Popanoceras walcotti, C. A. White, Am. Nat., Vol. XXIII, p. 117, Pl. I, figs. 9-11.

1591. Popanoceras walcotti, C. A. White, Bull. U. S. Geol. Survey No. 77, p. 21. Pl. I, figs. 9-11.

The following description is quoted from Dr. White's paper:

Shell discoid, periphery rounded; sides gently convex, the inner volutions amost wholly embraced by the next preceding one, and umbilici are conseduently minute. Surface marked with numerous slightly raised and slightly sinnous radiating ridges, apparently indicating stages of growth, which extend continuons ly from one umbilieus to the other acrosis the periphery; septa showing numerous short lobes and watdles, the former [the saddles] heing simple and regularly rounded at the ends and the latter [the lobes] more or less notehed or pointed at the extremity. Thase near the periphery have sometimes three digitations. and those near the umbilicuare simple and more or less pointed.

The speeinen had dianeter of about $26 \mathrm{~mm}$. and was entirely septate, hence the body chamber and aperture are unknown.

Occurrence.-Permian, military crossing of the Big Wichita River, Baylor County, Tex.

\section{Family CYCLOLOBIDA.}

Genus Shumardites Smith, gen. nov.

The type is Shumardites simondsi, sp. nov. Form subglobose, rather evolute, whorls highly arched, helmet-shaped, deeply embracing. Abdomen broadly rounded, sloping in a gentle anve to the abrupt umbilical shoulders. Umbilicus broad and deep. exposing the shoulders of the inner whorls. Surfure nearly smooth, except for a few obserure constrictions and traces of ribs on the umbilical border.

Septa complex, divided into numerous lobes and saddles; saddles all rounderd and constricted, lobes partly bifid, and becomings slightly ammonitie. Ventral lobe divided by a bottle-shaped siphonal saddle, the two lobes thus formed being unsymmetrically divided by a rather deep cleft: first lateral lobe similarly divided; second lateral lobe mucronate and tending to become trifid; third lateral lobe slightly divided: fourth lateral lobe on the umbilical shoulder, narrow and pointed; a fifth lobe stands on the umbilical border. Internal septa complex, consisting of a trifid 
antiwiphonal lobe, bitid first lateral lobe, and undividerl secombl latemal lobe. Internal saddles rounded like the extemal.

In youth the form of the whorls is gastrioceran, like Gastrioceras globulosum Ileek and Worthern, and Cr. subreacem Millex and Grurley; the comstrictions, form of the whorls, and the obserure traces of umbilical nodes all point to a gastrioceran ancestor, but the septa show a transition to the primitive Arestidex. A small specimen showed mintrinceran chanacters at diameter of $7 \mathrm{~mm}$, and those of Schistoceras at diameter of about $10 \mathrm{~mm}$., but the transition to shumardites takes place very quickly toward maturity.

In form this genus is a goniatite, but the septa have already made the transition to the ammonite stage of development; it might be placed with the Gilyphioneratidar, because of the crarlation through cirestrioceres, I'aralegneers, and s'chistoceras; but it is the most prinitive of the Aresteslike forms, and might with equal propriety be classed with the Arestidate The nearest known genus is IIyattoceras Gemmellaro, of the sicilian Permian, but shumardites has simpler septa than that genus, and may very possibly be the ancestor of it. The arrangement and shape of the lobes in Itanchoceras and other similar genera show that they have developed out of some genus like shumardites. Now, since ('yclolobus, Wrangenoceres, and Hyattoceras all show a common ancestry in shumentites or in some similar form, it is proper to group them all under the fimily C'rcholobide of "Zittel,

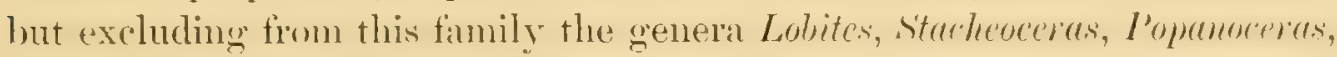

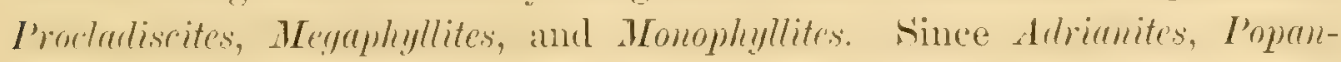
occres, and stacheoreras all seem to have been derived from Aguthireras, it is proper to class them under the family Popanoceratidar of IIyatt. Both families together would make up the Paleozoir superfanily Arcestida. But a single species of Shumardites is known, S. simondsi sp. nor., of the Upler Coal Measures, Cisen formation, or Missourian stage, of Craham, Young County, Tex. 'The generic name is given in honor of Dr. B. F. Shumard, the first State geologist of Texas.

\section{Shumaridites smondsi Smith, sp. nor.}

$$
\text { P1. III, figs. 3-13. }
$$

Shell sulgghobose, breadth equal to more than two-thirds of the cliameter'; evolute; whorls highly arched, helmet-shapeed, wice as wirle as high, 
deeply embracing, covering two-thirds of the inner rolution, and indented to ont-half of its height by the immer whorl. Abdomen broadly rounded in a curve that extends almost unchanged to the angular and steep umbilical shoulders. Umbilicus about one-third of the total diameter, deep, and exposing the umbilical shoulders of the inner whorls.

Surface smooth, so far as could be observed on the cast, except that a fer constrictions are visible, more common on the inner whorls.

Septa of the lanceolate type, saddles rounded and constricted, lohes also comstricted, and pointed. Ventral lobe divided by a notcherl siphomal saddle not quite so broad as the two divisions of the lobe. 'The ventral lohe is msymmetrically divided by a deep cleft on adventitions sadlle; the first lateral lobe is smaller than the ventral and is divided in the same unswmmetric way; the second lateral lobe is slightly larger than the first, and is mucromate in shape, showing a tendeney to beemes tripartites the third lateral lobe is similar to the first, except that it is the reverse of it. A fifth lobe, or anxiliary, sharply pointed and rather long, stands on the umbilical shoulder.

The internal septa consist of a tripartite antisiphomal lolue, a bifinl first lateral, and a simples second lateral, with a small auxiliary on the umbilical border.

The siphonal saddle is nearly as broad as the ventral lobes, the first lateral saddle is still broader, while the second and third laterals are narrow; the fourth lateral, just above the umbilical shoulder, is broad and short.

The lobes are not arranged in a straight line across the sides; but in a backwarl-pointing curve, which would suggest that the lateral lobes are secomdary, and have developeal out of a single primary lobe; this is borne out by the ontogeny of the species.

Ontoneny.-At the diameter of $7 \mathrm{~mm}$. the whorl is repressed, trapezoilal, and scarcely arched. The cast is marked by frequent deep and curved constrictions, and the septa, as shown on Pl. III, fig. 7, are gastrioceran, although the lateral lobe is begimning to hecome tripartite. This is the gastrioceran stage.

At diameter of $12 \mathrm{~mm}$. the ventral lobes have become much longer, and the lateral is divided into three nearly equal secondary lobes; at this stage the whorl is more highly arched, and the stage is transitional from Paraleyocerus to Schistoceras. The septa of this are shown on Pl. III, fig. 8. 
At diameter of $16 \mathrm{~mm}$. (one-half revolution more than at $12 \mathrm{~mm}$.) the three secondary lobes have ceased to show their orighin, and are arranged in a gentle coure arross the sides, no lomger corresponding to the shatpe of the original lateral. The whorls begin to be more highly arehed, and the stage corresponds to Schistoceras. The septa at this stage are shown on Pl. III, fig. 9.

At diameter of $22 \mathrm{~mm}$. (one-half' revolution more than at $16 \mathrm{~mm}$.) the ventral lobe begins to be divided unsymmetrically by a secondary saddle or notch; the first lateral is affected in the same way; the second lateral becomes strongly mucronate; the third lateral tends to become notched, like the ventral and first lateral. The siddles are all still roumded at this stage; the form of the whorl is as before, and the shell is making the transition from goniatite to ammonite, from the cilyphioneratide to the Arcestida; or from a distinctly Paleozoid type to an harbinger of the Ilesozoic era. The septal at this stage are slown on Pl. III, fic. 10, and the form of the whorl is shown on Pl. III, figs. 5 and 6 , which may be considered as the end of the adolescent, or paraneanic, period.

At diameter of $38 \mathrm{~mm}$. (one-half revolution more than at $22 \mathrm{~mm}$.) the ventral lobe is deeply divided on the side toward the umbilicus; the first lateral similarly divided, but reversed; the second lateral slightly tripartite; the third lateral like the first, but reversed. The saddles are deeply (onlstricted, and the general appearance of the lobes is phylloid, and sugrestive of Irangenoceras and Ityattoceras, of which genera shumardites is probably the ancestor. The septa of this, the adult, stage are shown on IPl. III, fig. 11, and the form on Pl. III, figs. 12 and 13.

The ancestry of shumardites isclearly seen in its successive stages thromgh

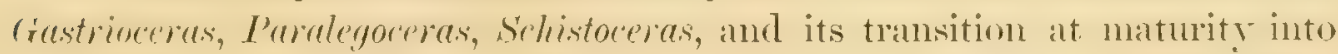
the primitive Arcestes type. That it is primitive is shown by the fact that it makes this transition at such a large size $(20 \mathrm{~mm}$. in diameter $)$, while all the Permian and Triassic forms make this transition shortly after their larval period, and at a very small size, thus illustrating the law of acceleration of development.

No other species is known with which Shumardites simondsi may be compared, for this type has not been found in the I'aleozoic deposits of other regions.

Occurrence-In the Upper Coal Measures, Cisco formation, Missomian 
stage, of Graham, Young County, Tex., associated with Gastrioceras globulosmm Meek and Worthen, lt. subcuvum Miller and Gurley, Schistocerus hildrethi Morton, S. hyatti Smith, Gonioloboceres aclleri Smith, Dimorphoceres texamm Smith, Agathiceras ciseoense Smith, s'chuchertites grahami Smith, I'openoceres yenti smith, and a typical brachiopord and pelecrpod coal Measures fauma. The beds in which these fossils were obtained lie about a thousand feet below the Wichita Permian beds. This is a remarkable assemblage of ammonites to be found below the Permian, but it will be noted, by reference to the plates acompanying this piper, that they are all primitive or transitional forms, such as one would expect to find in the Upper Coal Measures.

The type figured on Pl. III, figs. 11-13, was collected by the writer in the Cisco beds on Salt Creek, in the outskirts of Graham, Tex. Dimensions of the type:

Diameter, about

Milimeter.

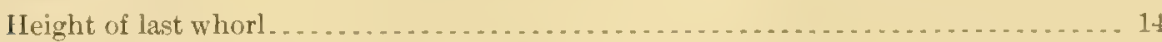

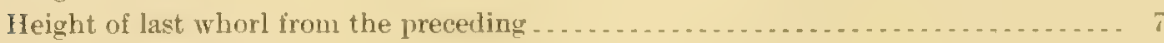

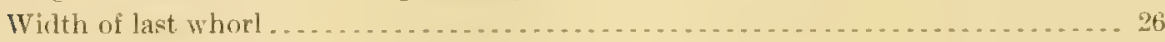

Involutim . . . . . . . . . . . . . . . . . . .

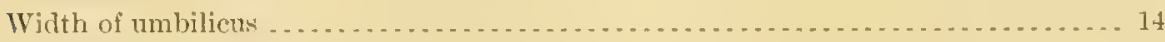

The type is in the collection of the writer, deposited in the geologic collection of Leland Stanford Junior University, California.

In the U. S. National Museum are three specimens (two of 27203 and one of 27201), which were also used in preparing the liagnosis of the germus and species, and in illustrating the development of the septa.

The specific name is given in honor of Prof. F. W. Simonds, of Austin, T'ex.

\section{Genus WaAgenoceras Gemmellaro.}

This is the most complex of American Paleozoic ammonoids, and the only one that in the strictest sense may be said to have dereloped entirely berombl the limits of the gonlatites and to have becomes a true ammonite in all its characters.

All known species of this genus have a compact Arcestes-like shape, with rounded whorl and moderately narrow umbilicus. The septa are complex, anmonitic and phylloid, the lobes and saddles numerous, and all digitate. The intemal divisions are almost as numerous as the external, in this respect strongly resembling Aicestes. 
'The shell is smooth, except for the transverse strixe of growth and the periodie constrictions on sulcations. This genus was first described by Gemmedlan" from the Permian of siveily, and has been found elsewhere only in 'Texas; it seems to be lacking in the Productus limestone of the Salt Range of India, and in the ILunginites heds of the Upper Permian of Armenia. On this account some writers have been inclined to regard

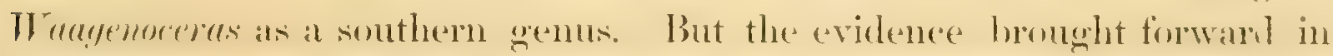
this paper shows that it probably developed in the Anerican recoion fiom the gastrioceran stock of the Glyphioceratidax, in the enenetie sevies Crastrinceras, Paralegoceras, Schistoceras, Shumardites, Waagenoceras.

The phylliform septa, the grobose wherls, and the constrictions all show that the genus could not have been derived from the Popanoceratidar, in which the septa are nerer phylliform, and the whorls usually laterally comm-

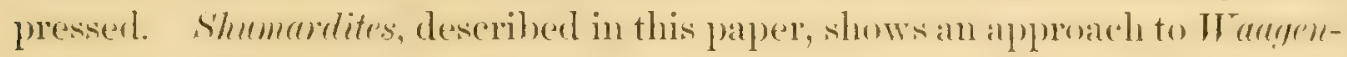
oceras, in the form of the whorls, the constrictions, and the beginning of phylliform digitation of the septa, and through this genus the family history can readily be traced back to Gastrioceras.

WaAgenoceras cummisi White.

P. XXII, figs. 4-8.

1859. Itychites cumminsi, C. A. White, Am. Nat., Vol. XXIII, p. 117, PI. I. figs. $4-8$.

1891. Waagenoceras cumminsi, (. A. White, Bull. U. S. Geol. Survey No. 77, p. 20 , Pl. I, figs. $t-8$.

1901. Popenoceres (IIyettites) crmminsi, F. Frech, Die Dyas, p. 512, figs. 3 and 4.

Shell subghobuse somewhat compleswed laterally, with hroadly rounded venter. Umbilicus rather deep and narrow, with small portion of the inner whorls showing. Cross section of whorl helmet-shaped, with greatest hreath at one-third of the height from the unbilical shoulders. Shetl nearly smooth, with fine cross strix, and fine spiral lines occasionally visible. Septa complex, the numerous lobes and saddles being all digitate: the siphonal lobe is deseply divided by a rather namow siphomal saddle, the lateral lobes are three in number, and in ardition to these theres are threese auxiliaries. 
The species seems to have reached a diameter of at least $50 \mathrm{~mm}$., but only fragments of the larger ones lave been found. The nearest known relative is Itnagenoceras stachei Gemmellaro, from the Permian Fusulina limestone of Sicily.

Occurrence and locality-Permian, Wichita stage, military crossing of the Big Wichita River, Baylor County, 'Tex.

WaAgenoceras Hilli Smith, sp. nov.

Pl. XXVII.

This species is more compressed laterally than Waugenoceras cumminsi White, has narrower umbilieus, and higher whorl, but the whorls are less deeply embracing, the involution being less tham one-half of the height of the whorl. There are five sinuous constrictions on the last revolution, which bend sharply hackwad on the abdomen. The surfite is otherwise smooth, so far as can be ascertained from the casts.

The septa are much more complex than on $W$. cumminsi at the same size, the lobes and saddles are all deephly divided; the saddles are phylliform, with three leat-like divisions; the lobes are digitate, with three principal finger-like extensions, resembling the reptal of I'hylloreres, and being more complex than those of any other species yet known of Itungenocras. There are seven lobes visible outside of the umbilicus, the ventral, five laterals, and one on the umbilical shoulder, being one less than is seen on the species described by Gemmellan" from the Permian of visily. The agreement with that geturs is not perfect, hut the "T'exas sprecies is neares to that than to any other, and the differencess are hardly sufficient for the discrimination even of a subgemus.

Dimensions of the tigurd specimen.

Millimeters

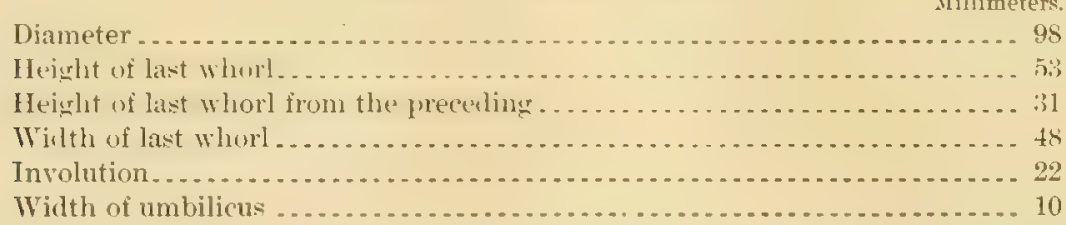

This specimen was septate throughout, so the length of the body chamber, and the full size of the shell could not be determined; but in the 
Areestida the length of the berdy chamber in at least at revolution, and this would almost double the size of the complete form.

None of the speceies described by Gemmellam are complarable with this one: they are all more depresserl and have less complicated digitation of

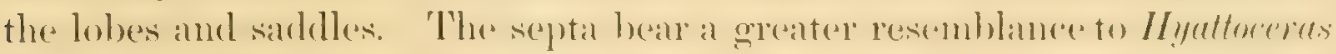

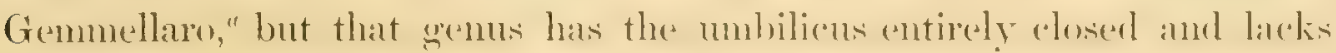
the constrictions or variees; also its saddles, while phyllifom, are distinetly bipartite and not tripartite as in Waagenoceras hilli.

Occurrence.-Waagenoceras hilli was collected by W. F. Cummins in the Double Momtain formation, CPper Permian, at the talls on salt ('rotom

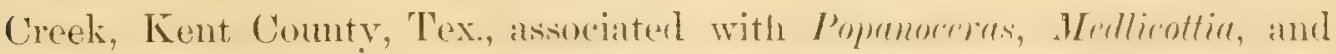
other forms possibly identical with those described by l). (.. A. White" from the Wiehita division. The type specimen was loaned the writer by the late Prof. Alpheus Hyatt.

The name is given in honor of Mr. R. T. Hill, of the U. S. Geological Survey, in recognition of his contributions to the geology of 'l'exas.

\section{SPECIES NOT GENERICALLT IDENTIFIED.}

\section{Goniatites? Colubrellus Morton.}

1836. Ammonites colutrellus, S. G. Morton, Am. Jour. Sci., 1st series, Vol. XXIX, p. 154 , pl. 28, figs. 49 and 51.

Shell discoidal, evolute, numerous convex volutions, laterally compressed. Three or four constrictions to a revolution.

Occurrence-Cupper Coal Measures, Cambridge, Guernsey ('omnty, Ohio.

\section{Goniatites? Minimus Shumard.}

1860. Goniatites minimus Shumard, Trans. St. Louis Acad. Sci., Vol. I, p. 200.

shell subgholose, involute. deeply embracing; lorearth expal to threefourths of diameter. Abdomen and sides strongly rounded. Unbilicus minute, not showing the inner whorls. Surface ornamented with exceedingly fine spiral lines; and obsedure nodes, visible on the umbilical shoulders.

Occurrence.-Middle Coal Measures, near Dovers Landing, Missouri. 


\section{Goniatites? parvus Shumard.}

1860. Goniatites parvus, B. F. Shumard, Trans. St. Lonis Acad. Sci., Vol. I, p. 199. Shell discoidal, moderately compresserl, strongly embranging, the inner whorls being concealed by the outer. Umbilicus very small. Abdomen strongly arched, sides gently convex; whorl higher than wide. Surface marked with a few obscure folds, strongest near the aperture.

Ocrumence-Upper Coal Measures, Willow spring, on Santa Fé road, Kansas.

\section{Goniatives ? POLITUS Shumard.}

1860. Goniatites politus, B. F. Shumard, Trans. St. Louis Acad. Sci., Vol. I, p. 199. Shell very much compressed laterally, thin, discoidal, involute, deeply embracing, the inner whorls being concealed by the outer. Abdomen strongly rounderl, smooth; sides evenly and gently convex, greatest thickness being about the middle of the whorl. Surface marked with obseure, sinuous folds and minute strix of growth, crossed by fine spiral lines.

Occurrence.-Middle Coal Measures, Lexington, Mo.

SPECIES NAIED BUT' NOT DESCRIBED.

Goniatites ? sulciferus Winchell.

1862. Goniatites sulciferns A. Winchell, Am. Jour. Sci., 2d series, Vol. XXXIII, p. 365:

No description given, but the suggestion is made that it may be a variety of "Goniatites" propinques Winchell.

Occurence.Lower Carboniferous, Kinderhook stage, Marshall formation, Marshall, Mich.

SPEGIES NOT AMINONOIUS.

"Ammonites" bellicosus Morton.

1836. Ammonites bellicasus, S. G. Morton, Am. Jour. Sci., 1st series, Vol. XXIX, p. 150, Pl. 11I, fig. 8.

This species is probably a nautiloid, but can not be determined.

Occurrence-Upper Coal Measures, Cambridge, Guemsey County, Ohio. 
STSTEMATIC POSITION DOUBTHUL.

Family NEOICOCERATID E.

Genus Neorcocelias Hyatt.

Neoicoceras exhornense Miller and Gurley.

Pate XVI, figs. 9-11.

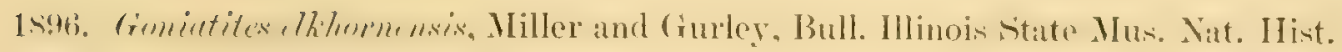
No. 11, p. 37, Pl. IV, figs. 9-11.

1900. Neoicoceras ellhornense, A. Hyatt, Cephalopoda, p. 550.

This species was taken by Hyatt as the type of a new genus and family of goniatites; the writer has examined the type specimen in the palentologic collection of the Walker Museum, University of Chicago, and is of the opinion that it is not an ammonoid at all, but a nautiloid.

Occurrence.-Middle Coal Measures, Elkhorn Creek, Kentucky. 
Tuble of the species.

\begin{tabular}{|c|c|c|c|c|c|c|c|}
\hline \multirow[b]{2}{*}{ Species. } & \multicolumn{3}{|c|}{ Lower Carboniferous. } & \multicolumn{3}{|c|}{ Coal Measures. } & \multirow{2}{*}{ Permian } \\
\hline & 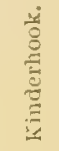 & $\frac{\vec{g}}{z}$ & 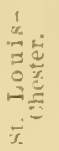 & 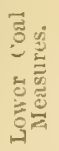 & 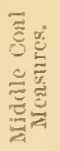 & 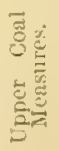 & \\
\hline
\end{tabular}

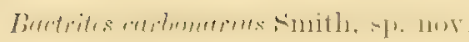

Agoniatites opimus White and Whitfield

Nomismoceres? muromse Worthen..

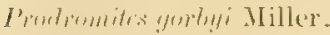

Prodromites ornatus Smith, sp. nov.

Prodromites primaturus Snith and Weller

Pronorites cyclolobus Phillips, var. arkansasensis Smith.

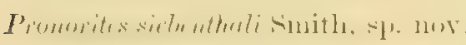

Yalliwhlu romi White.

Schuchertiles grahami Smith, sp. et gen. nov

Prolecunites? compactus Meek and Worthen

Prolementes ynemii Miller

Prolecanites gurleyi Snith, sp. nov.

Proherenits houghtoni Winchell

Prolecanites? lovisionensis Rowley

Prolecanites lyoni Meek and Worthen

Prolecanites marshallensis Winchell.

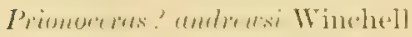

Primumetres.' Jromm next Miller.

Prionoceras? ohioense Winchell

Pericychus blairi Miller and Gurley.

P Pericyclus princeps De Koninck.

Glyphioceras calyx P'hillips

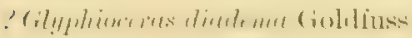

Glyphiocerts? halhauayanum MIChesney

Glyphioceras leviculum Miller and Faber.

Glyphioceras? yygmitum Winchell

Goniatites choctawensis Shumard

Goniatites erenistria Plillips

(Goniatites cumminsi Hyatt $=$ ( $\forall$. striutus Sowerby)

Gomidits greencuslensis Miller and Gurley

(Goniaties incisus Hyatt $=G$. crenistria Phillips)

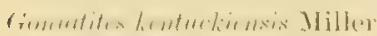

Gonictites lunutus Miller and Gurley

Goniatites newsomi Smith, sp. nov.

Gonintites sphacricus Martin

Goniatites striatus Sowerby

Gonatites subcirmlaris Miller 
Tuble of the syecis-Continued.

\begin{tabular}{|c|c|c|c|c|c|c|c|}
\hline \multirow[b]{2}{*}{ 'vereses, } & \multicolumn{3}{|c|}{ Lower Curbmiferons. } & \multicolumn{3}{|c|}{ Coni Mensures, } & I'ermian \\
\hline & 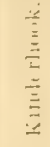 & $\dot{\vec{y}}$ & 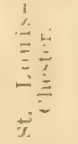 & 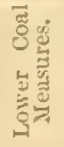 & 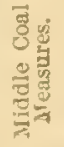 & 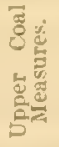 & 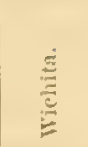 \\
\hline
\end{tabular}

Gastriorems trameri smith

Gostrioreves carlmarim von Buch

Guslriocerus compressum Hyatt

Gastriaceras entogonum Gabb)

Giastrioreras excelsum Meek

Gustriocercs globulosum Meek and Worthen.

Gastrioceras illinoisense Miller and Gurley

Gastrioceras krmsasmse Miller and Gurley

Gastrioceras kingi Hall and Whitfield

Gostrioceras listeri Martin

Gustrioceras montgomeryense Jliller and Gurley.

Gerstrinceras nolimense Cox

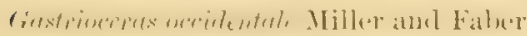

Gestrioceras plenorbiforme Shumard.

Gastrioceras subcam Miller and Gurley

Gastrioceras welleri Smith, sp. nov

Puralegoceras baylorense White.

Parregoceras iowense Meek and Worthen.

Paralegoceras neusomi Smith

I'uralegoceras texanum Shunarl

Schistoceras fultonense Miller and Gurley

Schistoceras hildrethi Morton

Schistoceras hyatti Smith.

Schistoceras missmeriense Miller and Faber

Agrarides discoidalis Smith, sp. nov

Aganides jessiex Miller and Gurley*

Agamides? propinguus Winchell

Aganides: romingeri Winchell

Aganides rotatorius de Koninck

Agunides? sciotoensis Miller and Faber

Aganides? shumardianus Winchell.

Muensteroceras? holmesi Swallow.

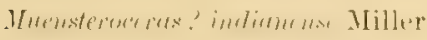

Muensteroceras osagense Swallow

Muensteroceras oueni Hall

Muensteroceras parallelum Hall.

(Muensteroceras whitei Hyatt $=M$. oweni Hall)

Cionioloboceras? allei Winchell.

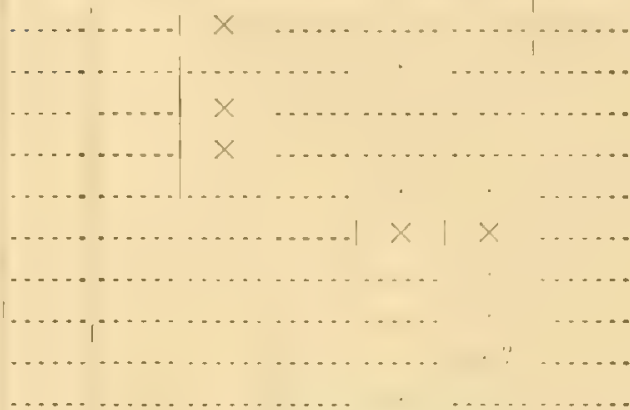


Table of the species -Continued.

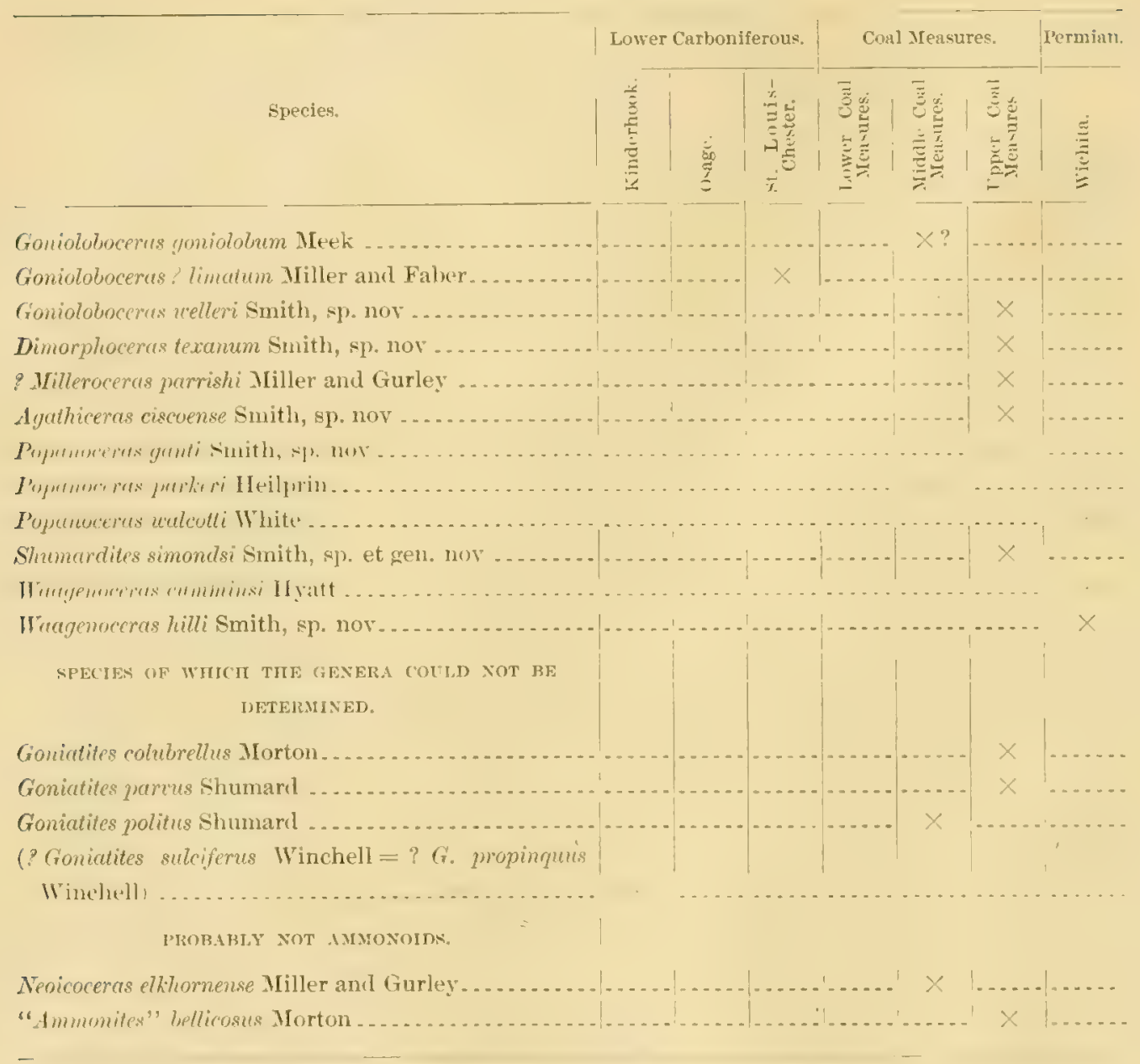




\section{BIBLIOGRAPHY.}

JEIIOIRS IN WHICH AJERICAN CARBONIFEROUS (YONIATITES ARE TOESCRIBED.

Barrors, C. Terrains anciens des Asturies et de la Galice.

Mém. Sire, réol. du Nort, Vol. II, No. 1, 1882.

Berxard, F. Traité de Paléontologre. 1895.

Beyricu, E. De Goniatitis in Montibus Rhenanis oecurrentibus. 1537.

Beitrïge \%. Kenntniss Versteinerungen rheinischen Ueberqangsgebirges. 1837.

Brasis, J. J. 'Thesaurus Devonico-Carboniferus. 1878.

Braxco, W. Beitrïge zu Entwicklungsgeschichte der fossilen Ćphalopoden. Palreontographica, Vol. XXVII, 1880.

Buch, L. vox. Ueber Goniatiten.

P'hysical. Abhandl. d. K. Akad. Wiss. Berin, 1830.

C'arke, J. M. 'The Naples fauna (fauna with Manticoveras intumescens) in Western New York.

Sixteenth Ann. Rept. New York State Geologist, 1898, p. 29-161.

Cox, E. 'T. Palæontological report of Coal Measure Mollusca.

Geological Survey of Kentucky, Vol, III, 1857.

Crick, G. C. On the muscular attachment of the aninal to its shell in some fossil Cephalopoda (Ammonoidea).

Trans. Linnean Soe. Zool., ser. 2, Vol. VII, part 4, 1898

Cumurs, W. F. Report on the geology of northwestern lexas. Second Ann. Rept. Geol. Surv. Texas, 1891.

Foord. A. H., and Crick, G. C. Catalogue of the Fossil Cephalopoca in the British Museum, Part III, 1897.

Frech, Fritz. Die Steinkohlenformation.

Lethrea Geognostica, Part I, Vol. II, No. 2, 1899.

- Die Dyas.

Lethra Geognostica, Part I, Vol. II, No. 3, 1901.

Ueber devonische Ammoneen.

Beitr. zur. Pal. u. Geol. Oesterreich-Ungarns u. des Orientu, Vol. X̃IV, 1901.

Gais, W. M. Descriptions of new species of American Tertiary fossils and a new Carboniferous cephalopod from Texas.

Proc. Acad. Nat. Sci. I’hila., 1861.

Gemalelaro, G. G. La fauna dei calcari con Fusulina della valle del fiume Sosio. Giornale Sci. Nat. Econom. Palermo, Tol. XIX, 1888, and Vol. XX, 1590.

HAL. JAMEs. Notes and observations on the fossils of the Goniatite limestone in the Marcellus shale of the Hamilton group, ete.

Thirteenth Ann. Rept. New York State Cabinet Nat. Hist., 1860.

Natural History of New York. Paliontology. Vol. V, I’t. II, 1879.

Hall. J., and Winteield, R. P. Paleontology.

U. S. Creol. Expl. Fortieth Parallel, Tol. IV, Part 1I, 1877. 
Ilavo, F. Fitules sur les Coniatites.

Mém. Sone, Gónol. lirance, P'aléont., Vol. VIf, No. 18, 1898.

Inempres, A. On a Carboniferons ammmonite from 'lexas.

Pror. Ararl. Nat. Sci. l'hila., 1884.

Herrick, C. L. Observations upon the so-ealled Warerly group of Ohio. reol. Surv, Ohio, Vol. V1I, 189.5.

Hotzapreta, E. Die Cephalopoden-führenden Kalke des unteren Carbon von Erdbach-

Breitseheid bei Ilerborn.

Pal. Ahhandl, Dames and Kayser, Vol. V, 18s8,

HYatr, ג. Cephalopoda.

In Lastman's transl. 'Zittel's Text-13uok of l'alieontology, 1900.

Curboniferous cephalopods.

secund Ann. Rept. (ieol. Surv. Texas, 18:11.

Caboniferous cephatopods. Second paper.

Fourth inn. Rept. (icol. Surv. Texas, $189 \%$.

Genera of fossil ecphatopods.

l'roc. Boston Soe. Nat. I List, Vol. XXII, 1884.

Fossil cephalopods of the Museum of Comparative Zoology. Embryology. Bu1l. Mus, Comp. Zool. ILarvard College, Vol. III, No. 5, 1872.

Kantressy, A. Ueber die Ammoneen der Artinsk-Stufe.

Mém. Acal. Imp. Sei. St. Petershourg, 7th series, Yol. XXXVII, No.2, 18s9.

Konnck, 1. G. DE. Deseription des animax fossiles qui se trouvent daus lo terrain carbonifere de Belgique. 1840-14.

—_ Fane du calcaire eabonifère de la Belgigue. 1880.

Mantin. W. Petrifacata Derbiensia. 1809.

McChessex, J. II. Descriptions of new species of fossils from the latleozoic rocks of the Writern states. 1860 .

Plates illustrating in part the new species of fossils from the P'alarozoic rocks of the Western States, ete. 1865.

Deseriptions of fossils from the Palivozoic rocks of the Western States.

Trams. Chicago Acad. Nci., Vol. 1, 1868.

McCox, F. British Palieozole fossils. 185\%.

Мвек, L. B. l'aleontology.

I. S. cieol. Expl. Fortieth l'arallel, Vol. IV, P'art I, 1877.

Notice of a very large goniatite from eastern Kansas.

Bull. U. S. Geol. Survey Terr., Vol. I, No. 6, 18:5.

MeEk, F. 13. and WokTuEN, A. H. Descriptions of new Caroniferous fossils from Illinois and other Western States.

Proe. Aled. Nat. Sci. Phila., 1860.

Indiana, ete.

Remarks on the age of the Goniatite linestone at Rockford,

du. Jour. Sci., 2d series, Yol. Xxxil, 1861.

Descriptions of new species of Crinoidea [etc.] from Illinois.

Proce, Lem. Nat. Sci. Phila., 1865.

Descriptions of invertebrates from the Curboniferous system.

Geol. Surv. Illinois, Voul. II, l'alcontology, 186ti. 
МЕeк, l. B. and Wontrus, ג. II. Deseriptions of invertebrates from the Carboniferous system.

(ieol. Surv. Illinois, Vol, V, I'aleontoligy, 187:3.

Western States.

Proc. Acarl, Nat. Fei. Philit., 18tio,

Mrrexir, S. A. North American (ieologry and Palivontology. 188\%.

l'aleontology.

Seventeenth Ann. Rept, fieol. Nurv. Indiana, 18:2.

Paleontology.

Wighteenth Ann. Rept. (ieol. Nurv. Inliana, 18\%4.

MrLeER, S. A. and FABLr, C. Descriptions of some Subcarboniforous and Carboniferous Cephalopodi.

Jour. Cincinnati Sine, Nat, 11 ist., Vol, XIV, 1892.

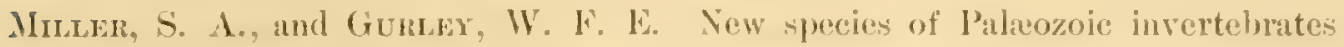
from Illinois and other States.

Ball. Hlinois State Mus. Nat. Hist. No. 11, 1896.

Morsisovics E. von. Die Cephalopoden der Mediterranen Triasprovinz.

1hhanrl. K. K. Geol. Rerchsantalt Wien, Vol. X, 1882.

Montfort DE, D. Conchyliologie systématique, Vol. I. 1808.

Montor, S. G. Appendix. Being a notice and description of the oreranic renains embraced in the preceding paper.

Aprendix to S. I'. IIildreth's paper on the Bituminous coal deposits of the Valley of the Ohio. Am. Jour. Aci., 1st series, Vol. XXIX, 18:6).

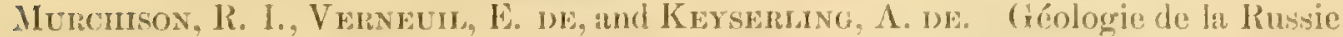
d'Europe et des montagnes de l'Oural. Vol. II. Palécontologie. $18+5$.

Primlips, I. Illustrations of the Geology of Yorkshire, Pt. II. $18: 36$.

Rowier, Fen1). Iethera Geognostica, P’t. I, Palacozoica, Vol. 1I. 1852-5t. Geologie von Oberschlesien. 1870.

Lethas Geonnostica, Pt. I, Jethaxa Palacozoica, Vol. I. 1876.

Rovyer, F. IDOLPI. Beitrïge zur geologischen Kenntniss der nordwestlichen Harzgebirges. I'aleontographica, Vol. III. 1850-52. Vol. V, 1855. V'ol. 1X, 1860.

Rowler, R. R. Description of a new genus and five new species of fossils from the Devonian and Subcarboniferous rocks of Missouri. Am. Geologist, Vol. XVI, No, 4, 1895.

SAxpberger, F. Die Versteinerungen des rheinischen Sehichtensystems in Nasiau. $1850-56$.

Sinuard, B. F. Description of new fossils from the Coal Measures of Missouri and Kansas.

Trans. St. Louis Acarl. Sci., Vol. I, 1858.

Palaontology.

Gienl. Survey Missouri, 1855.

- Descriptions of new Palcozoic fossils. Trane. St. Louis Acad. Sei., Vol. II, 1863.

Surtir. o. P. Marine fosilis from the Coal Measures of A lrkansas. l'roc. Am. Philos. Soc, lou. XXXil, 1896. 
Surti, J. P. The development of Glyphioceras and the phylogeny of the Glyphoceratidr.

Proc. Cal, Acad. Sci., 3il series, Geology, Vol, I, 1897.

Suith, .J. P., and Weller, StuART. Prodromites, a new ammonite genus from the Lower Carboniferous.

Jour. Geol., Vol. IX, No. 3, 1901.

Sowerby, J. Mineral Conchology of Great Britain, Vol. I. 1814.

Steinuane, G., and Dönerlein, L. Elemente der Paläontologie. 1890.

Swallow, G. C. Descriptions of new fossils from the Carboniferous and Deronian rocks of Missouri.

Trans. St. Louis Acad. Sci., Vol. I, 1860.

Tzwetaev, M. Nantiloidea et Ammonoidea de la section inférieure Calcaire Carbonifère Russie.

Mém. Comité Géol. St. Pétersbourg, Vol. VIII, To. f, 1898.

Verneuru, E. De. Note sur le parallélisme des roches des dépôts paléozoïques de l'Amérique Septentrionale avec ceux de l'Europe, etc. Bull. Soc. Géol. France, 2d series, Vol. IV, 1847.

WaAgen, W. Salt Range Fossils.

Pal. Indica, Ser. XIII, Vol. I, 1879.

IVeller, Stuart. The Batesville sandstone of Arkansas.

Trans. New York Acarl. Sci., Vol. XVI, 1897.

Kinderhook Faunal Studies. II. The Fauna of the Chonopectus sandstone at Burlington, Iowa.

Trans. St. Louis Acad. Sci., Vol. X, No, 3, 1900.

_ A bibliographic index of North American Carboniferous invertebrates. Bull. U. S. Geol. Survey No. 153, 1898.

White, C. A. On the Permian formation of 'Texas. Am. Naturalist, Vol. XXIII, 1889.

The Texas Permian and its Mesozoic types of fossils.

Bull. U. S. Geol. Survey No. 77. 1891.

Paleontology. Fossils of the Indiana rocks.

Second Anu. Rept. Dept. Stat. and Geol. Indiana, 1881.

Winte, C. A., and Whitfield, R. P. Observations on the rocks of the Mississippi Valler, ete.

Proc, Boston Soc. Nat. Hist., Vol. VIII, 186\%.

Winchelt, A. Notice on the rocks lying between the Carboniferous limestone of

the Lower Peninsula of Michigan and the limestone of the Hamilton group, etc. Am. Jour. Sci., 2 d series, Vol. Xxxill, 1862.

Descriptions of new species of fossils from the Marshall group of Michigan. Proc. Acad. Nat. Sci., I'lila., 1865.

Notices and descriptions of fossils from the Marshall group of the Western States. Proc. Am. Philos, Soc, Vol. XI, 1870.

Wortiex, A. H. Paleontology. Geol. Survey Illinois, Vol. VIII, 1890.

Zittel, K. A. vox. Grundzïge der Palæontologie. 1895. Handbuch der Palxontologie, Pt. I, Vol. II. 1885. 


\section{P L A TES.}


PLATE III. 


\section{PLATE III.}

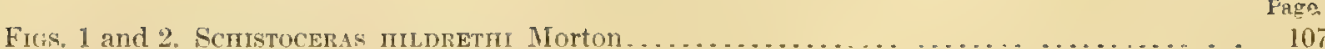

Upper Coal Measures, Cambridge, Ohio.

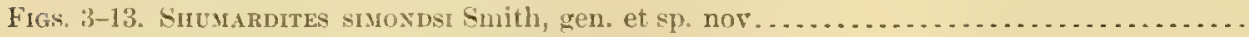

Upper Coal Measures, Cisco formation, Grahaw, Tex.

Figs. 3 and 4. Views of young shell, at diameter of $22 \mathrm{~mm}$, showing gastrioceran shape of whorl.

Figs. 5 and 6 . Partial restoration of the above specimen.

Fig. 7. Septa showing gastrioceran character and beginning of division of lateral lobe, at diameter of 7 mm., 10 times enlarged.

Fig. 8. Septa at diameter of $12 \mathrm{~mm}$., transitional from P'uralegoceras to Schistoceras; 3.6 times enlarged.

Fig. 9. Septa at diameter of $16 \mathrm{~mm}$. (one-half revolution more than tig. 8), 3.6 times enlarged. (Septa inverted.)

Fig. 10. Septa at diameter of $22 \mathrm{~mm}$. (one-half revolution more than fig. 9), 4 times enlarged.

Fig. 11. Septa at $38 \mathrm{~mm}$. (one-half revolution more than fig. 10), showing mature characters; drawn from specimen shown in figs. 12 and 13, 1.6 times enlarged.

Figs. 12 and 13. Type specimen, natural size.

Note.-Figs. 1 and 2 are figs. $40 a$ and $40 b$ of PI. I of Etude sur les Goniatites. 

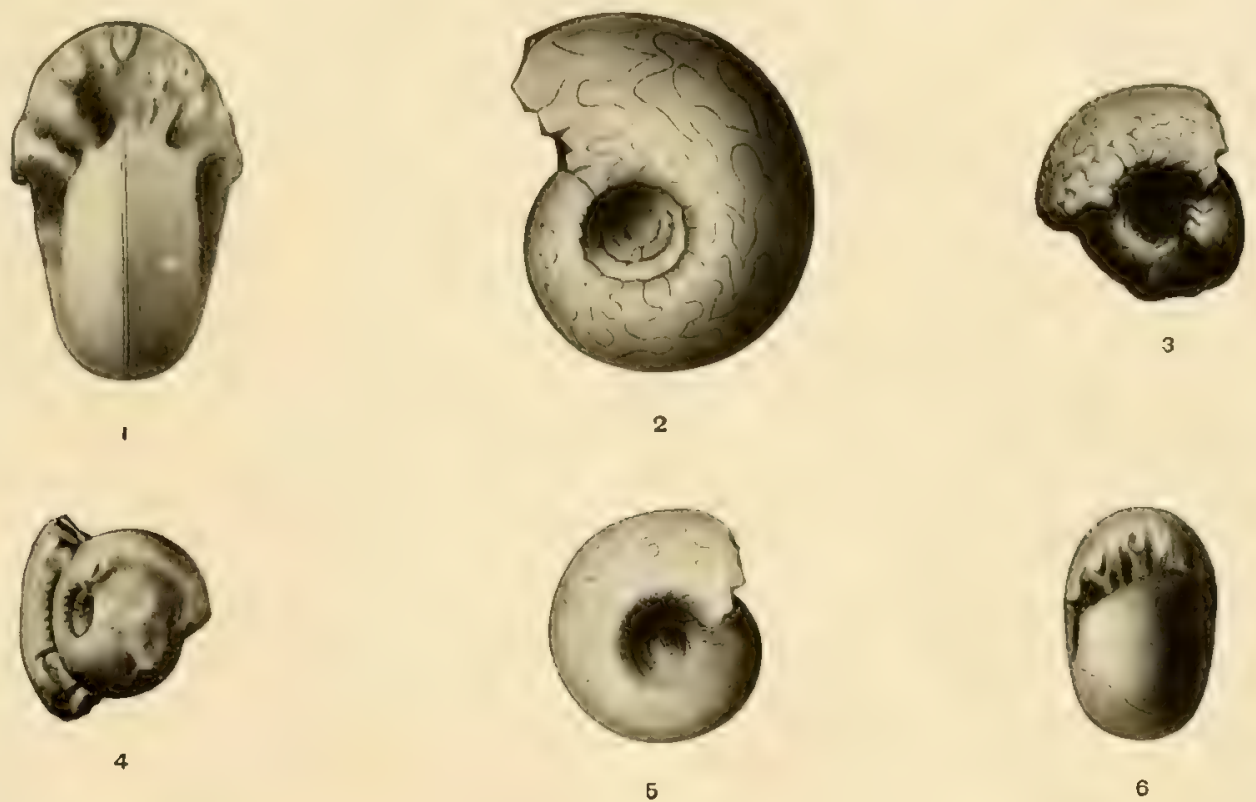

4

6
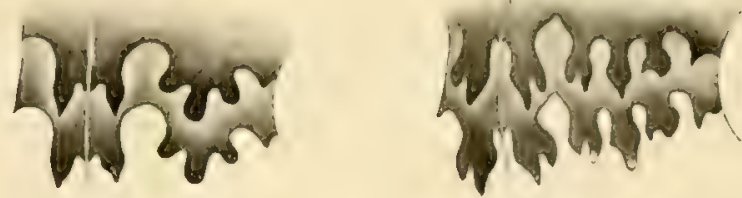

8
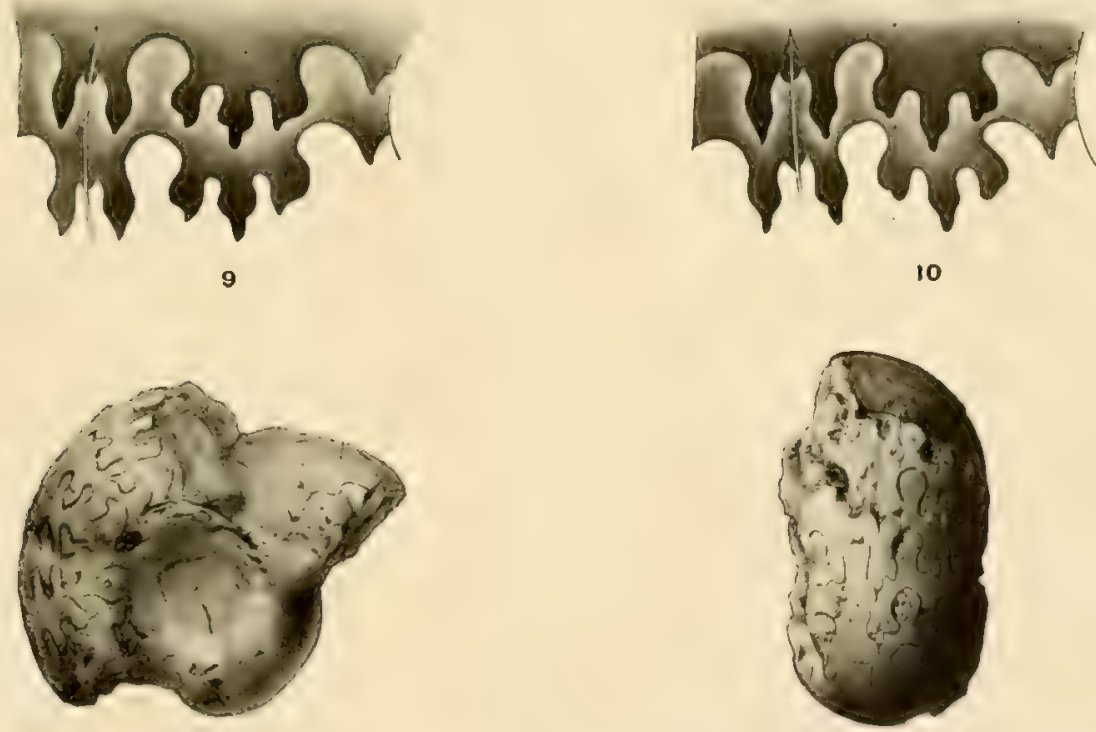

12

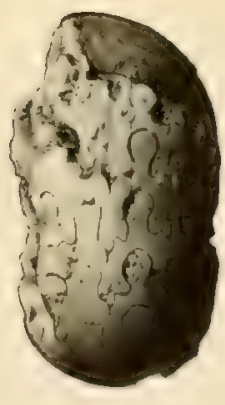

13 

PLATE IV. 


\section{PIATE IV.}

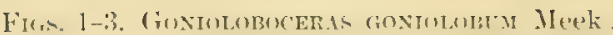
Coal Measures, New Mexico.

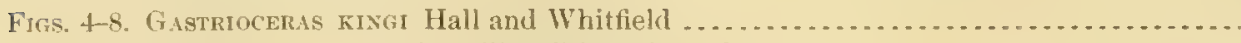

Coal Measure, Eberhardt Mill, White Pine, Nev.

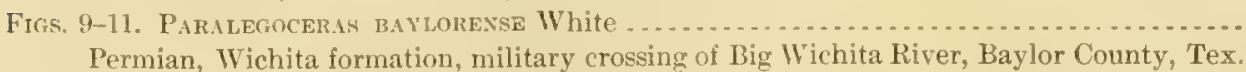

Figs. 12-14. Paralegoceras iowense Meek and Worthen ................................. Middle Coal Measures, Alpine, Iowa.

Note.-Figs, 1-3 are from U. S. Geol. Expl. Fortieth Parallel, Vol. IV, Pt. I, Pl. IX, figs. 5, 5a, 5 b. Figs, t-8 are from U.S. Geol. Expl. Fortieth Parallel, Vol. IV, Pt. II, PI. VI, figs. 9-14. Fics, 9-11 are from Bull. U. S. Geol, Survey 5o. 77, P. II, figs. 1-3.

Figs. 12-1t are from Geol. Surv, Illinois, Vol. II, Pl. IXI, figs. 3a-c. 


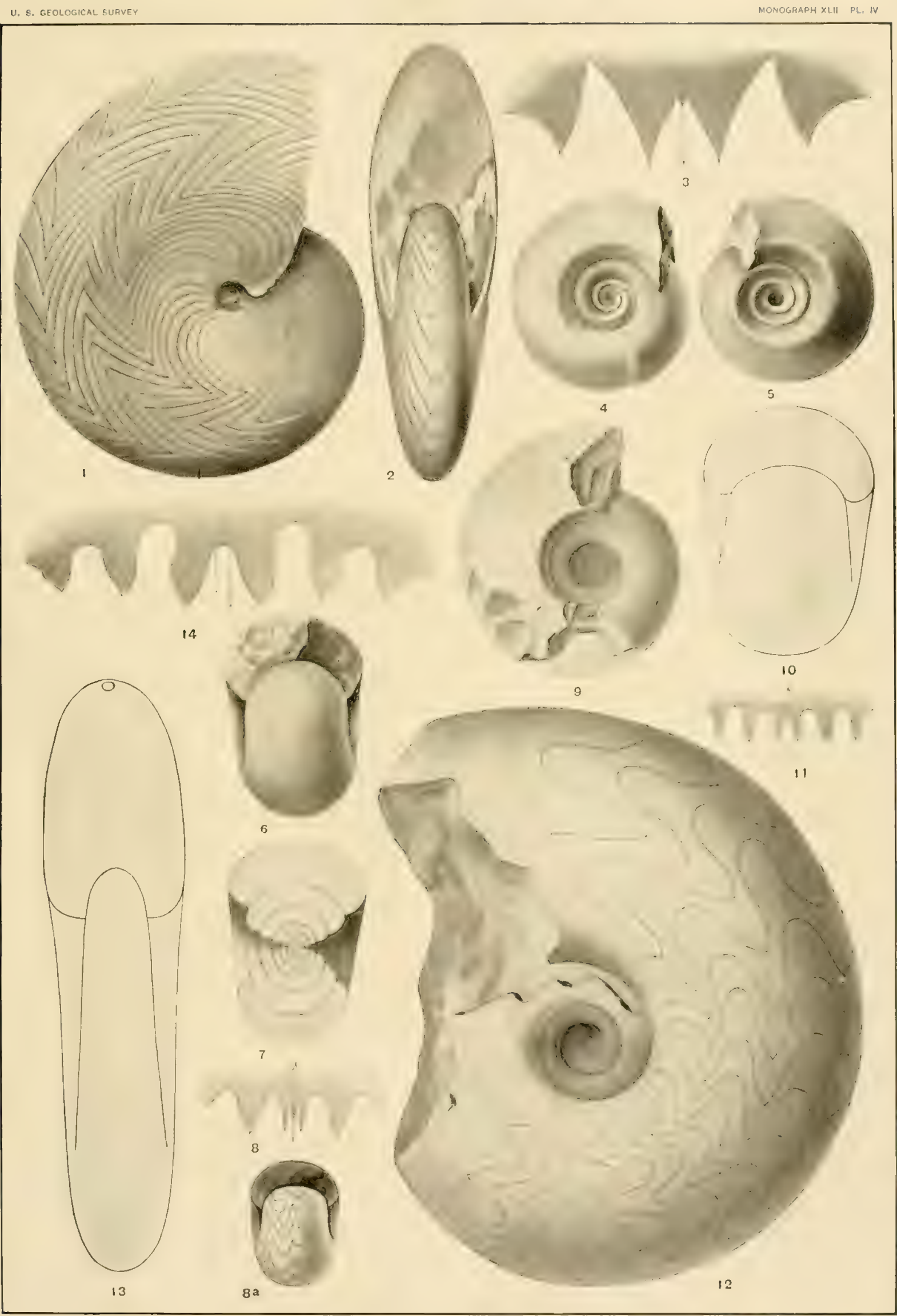

CARBONIFEROUS AMMONOIDS. 



\section{PLATE V.}


PLATE $V$.

Page.

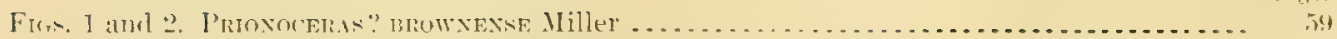

Lower Carboniferous, Kinderhook group, Brown County, Ind.

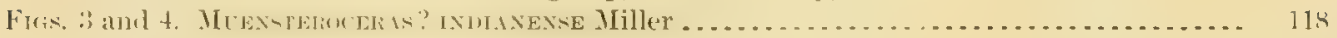

Lower Carboniferous, Kinderhook group, Clark County, Ind.

Figs. 5-7. Prolecanites? cospictus Mleek and Worthen ............................

Middle Coal Measures, Menard County, 111.

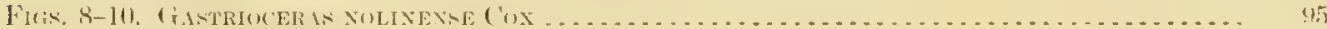

Iiddle Coal Measures, Nolin Iron Works, Edmonson County, Ky.

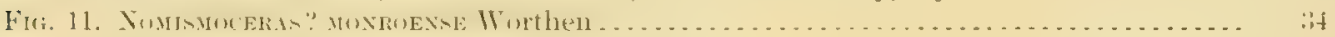

Lower Carboniferous, St. Louis group, Monroe, Ill.

Note.-Figs. 1 and 2 are from Seventeenth Ann. Rept. Geol. Surv., Indiana, Pl. XVIII, figs. 3 and 4 .

Figs. 3 and 4 are from Seventeenth Ann. Rept. (ieol. Surv., Indiana, 1'. XIX, figs. 2 and 3.

Eigs. 5-7 are from Geol. Surv. Illinois, Vol. V, Pl. XXII, figs. "2 a-c.

Figs. 8-10 are from Geol. Surv. Kentucky, Vol. III, Pl. X, figs. 1, 1a, 1b.

Fig. 11 is from Geol. Surv. Illinois, Vol. VIII, Pl. XXVI, fig. 5. 


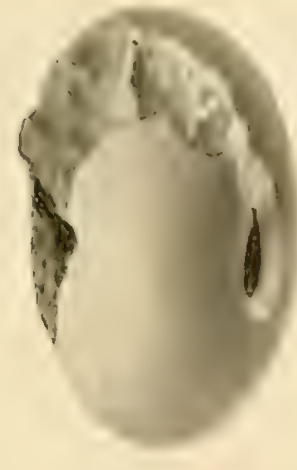

1

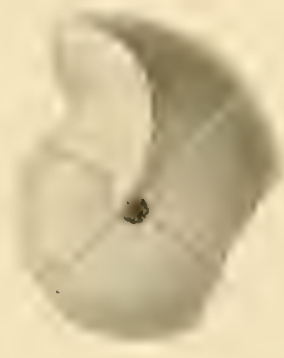

3
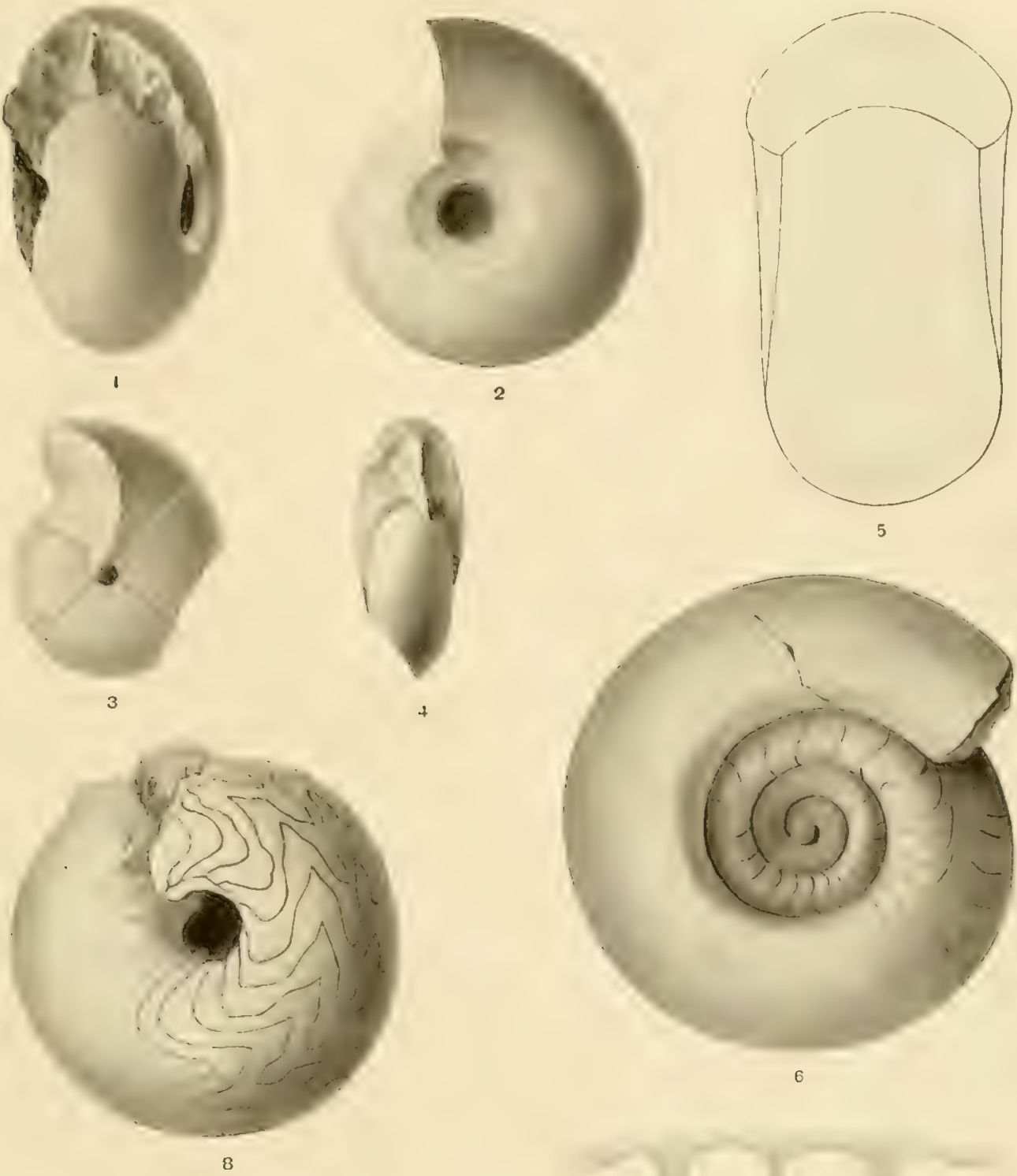

$+$
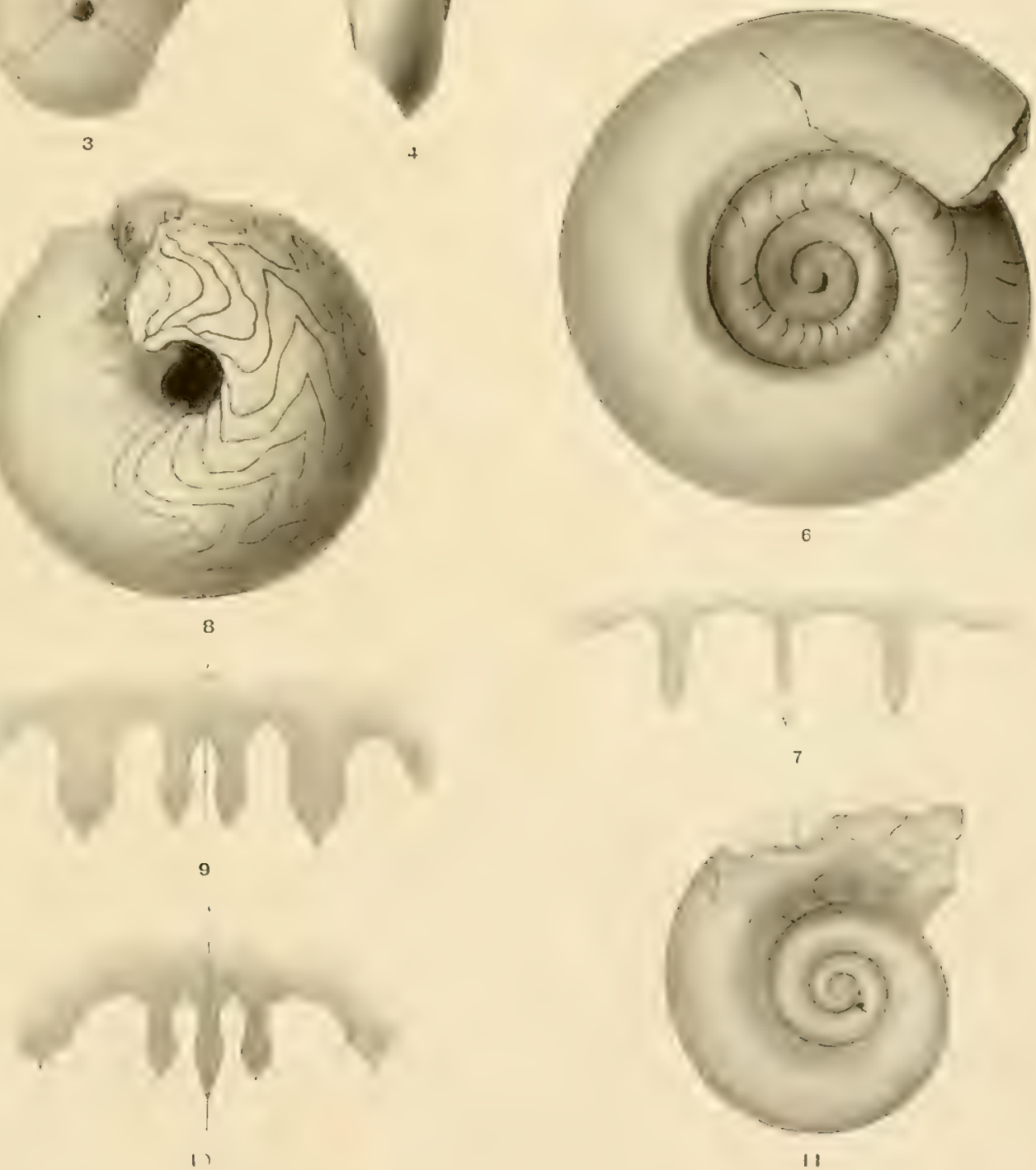

PLATE VI. 


\section{PLA'T'E VI.}

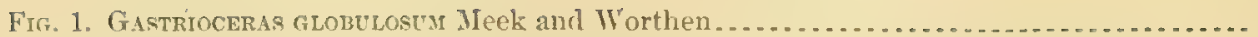

Middle Coal Measures, near Boles, Ark. Shows the surface markings of the shell.

Coal Measures, Elkhorn Creek, Kentucky.

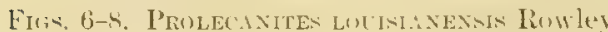

Lower Carboniferons, Kinderhook stage, Louisiana, Mo.

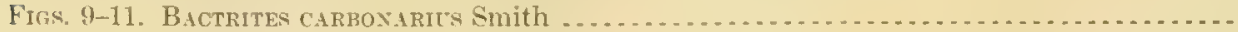

Lower Carboniferous, St. Louis-Chester stage, Moorefield, Ark.

Note-Fig. 1 is from Proc. Am. Philos. Soc., Vol. XXXV, Pl. XVIII, fig. 4.

Figs. 2-5 are frnm Bull. Illinois State 1Lus. Nat. Hist. No. 11, Pl. V, figs. 2-5.

Figs. 6-8 are after a specimen loaned by the Walker Museum, University of Chicago. 

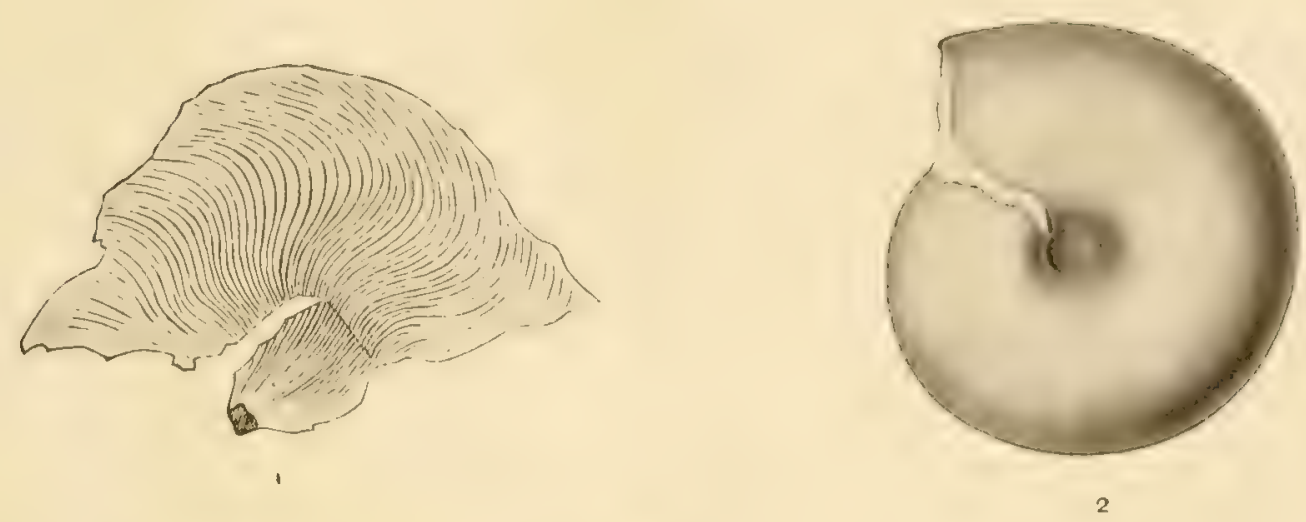

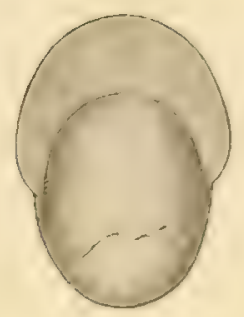

3

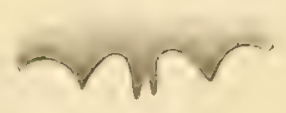

4

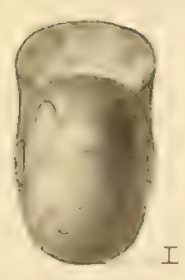

7

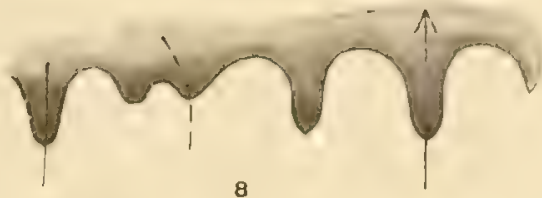

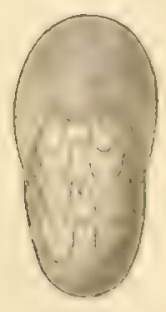

5

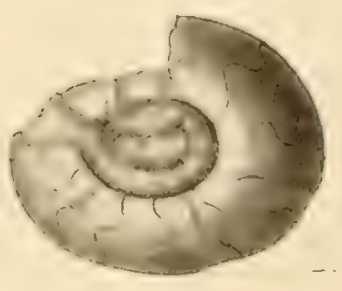

6

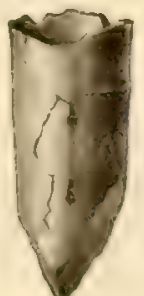

10

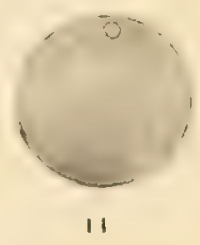





\section{PLATE VII.}

ION XIII-1:2-11 


\section{PLATE VII.}

l'age.

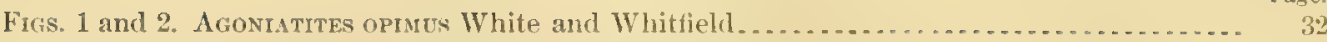
Lower Carboniferous, Kinderlıok stage, Burlington, Iow.

Fig. 1, outline of the whorl.

Fig. 2, side view.

Noте. - These drawings are copied from Dr. Stuart Weller's paper, Kinderhook Faunal Studies, II, The Fauna of the Chonopectus sandstone at Burlington, Iowa: Trans. St. Louis Acad. Sci., Vol. X, No. 3, Pl. VIII, fig. 1 ; and Pl. IX, fig. 1. 


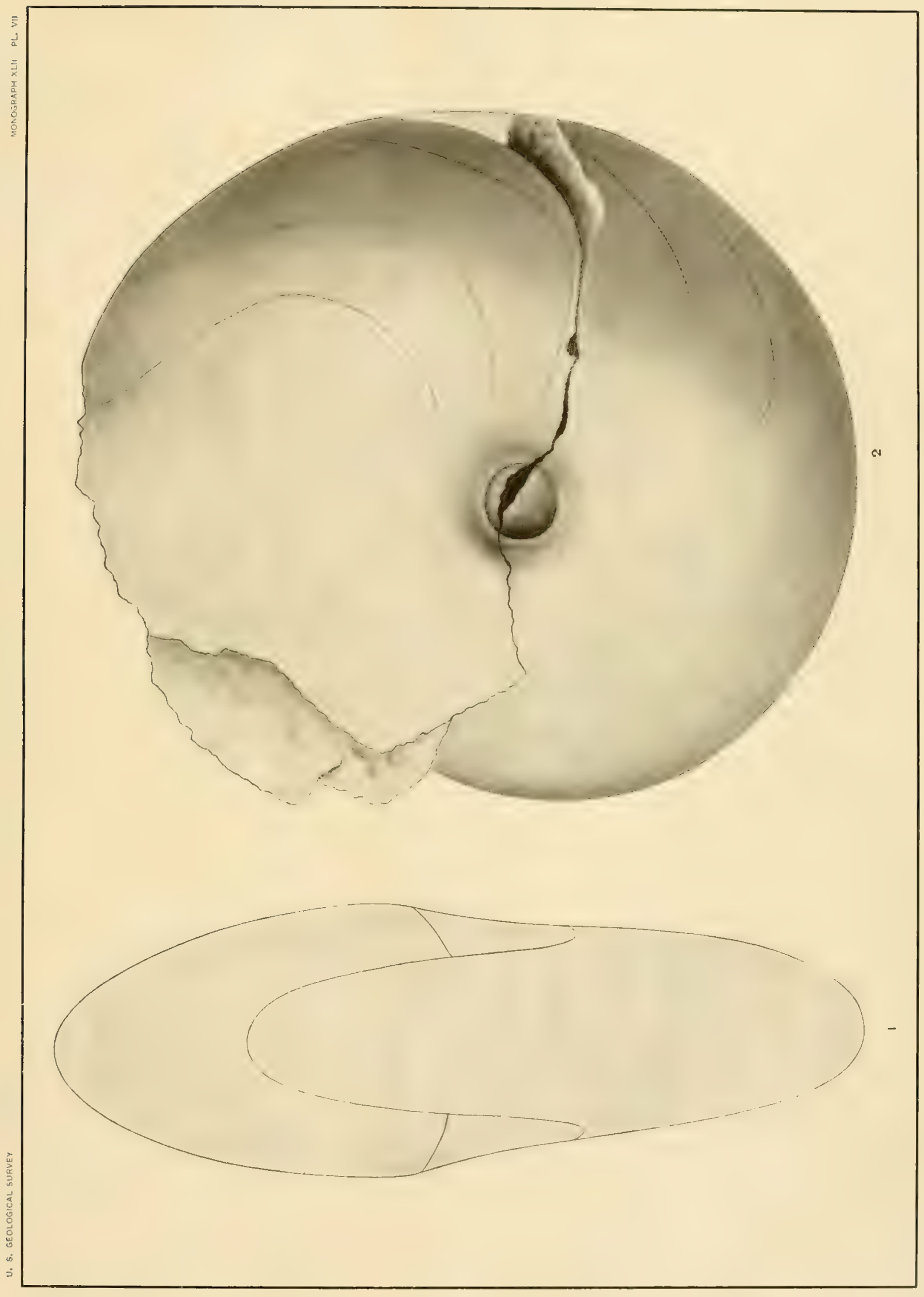



PLATE VIII. 


\section{PLATE VIII.}

Fif. 1. Schistoceras missouriexse Millet and Faber . . . . . . . . . . . . . . . . . . . ...... 111

Upper Coal Measures, near Kansas City, Mo.

Firs. 2 and 3. Aganides? sciotoexsis Miller and Faber.

Lower Carboniferous, Osage stage, Sciotoville, Ohio.

Figs. 4, 5, and 5 $a$. Pholecanites greenil Miller

Lower Carboniferous, Kinderhook stage, New Albany, Ind.

Figs. 6 and 7. Gastrioceras occidentale Miller and Faber

Middle Coal Measures, Elkhorn Creek, Kentucky.

Fits, 8 and 9. Grovioloboceras? Limatum Miller and Faber.

Lower Carboniferous, St. Louis stage, Crab Orchard, Ky.

Fifs. 10 and 11. Gly PHioceras Leviculcm Milier and Faber.

Lower Carboniferous, St. Louis stage, Crab Orchard, $\mathrm{Ky}$.

NoTE.-Figs. 1-3 and 6-11 are taken from Jour. Cincinnati Soc. Nat. Hist., Vol. XIV, PI. VI

Figs. 4 , 5, and 5 are taken from Seventeenth Ann. Rept. Geol. Surv. Indiana, I'. X, figs. 5 and 6 . 

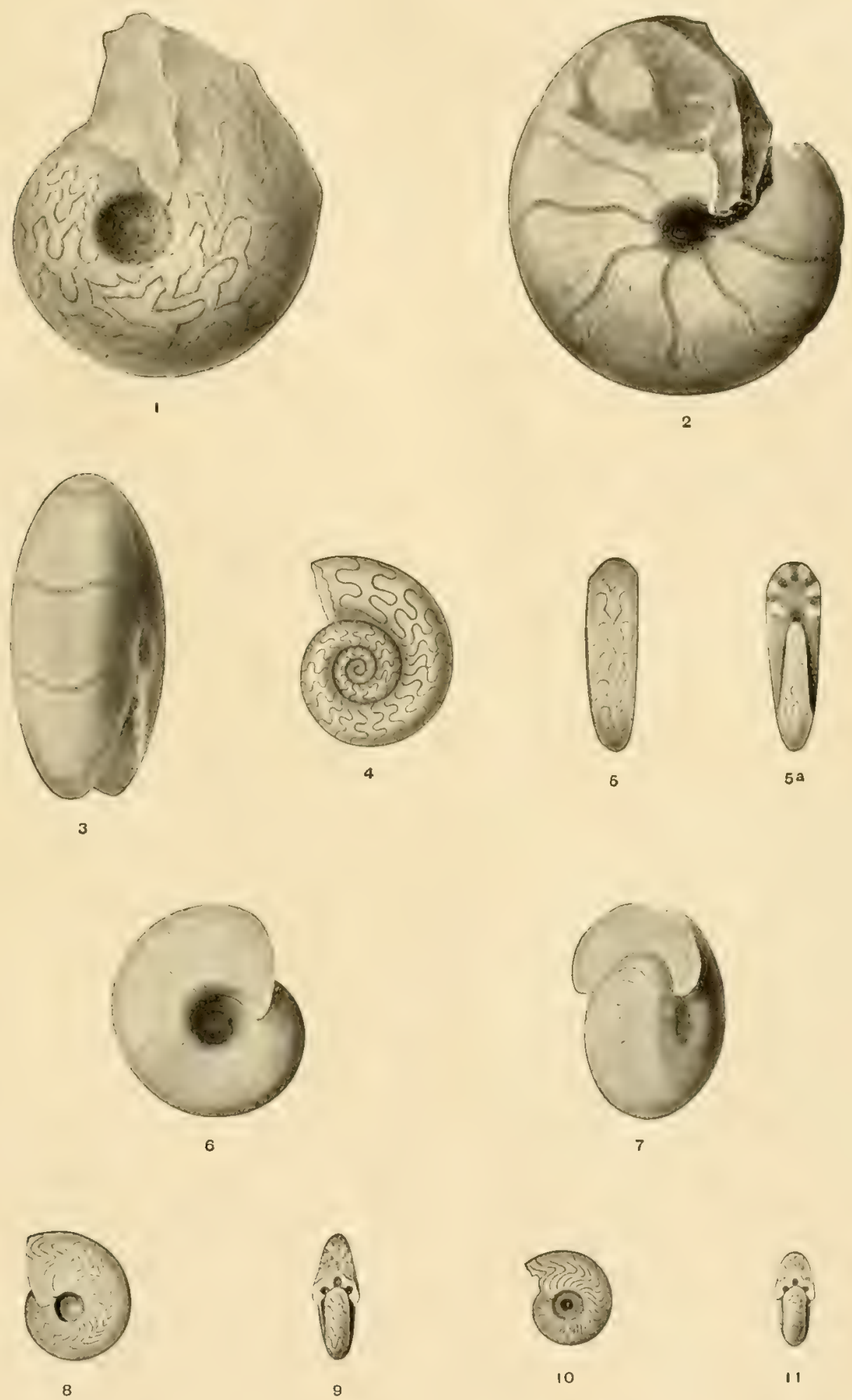

PLATE IX. 


\section{PLATE IX.}

l'tite.

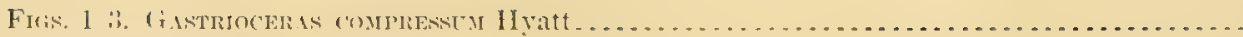

Lower Carboniferous, St. Iouis-Chester stage, Bend formation, San Saba County, neas Bend, Tex. specimen Nat. Museum.

Figis. 4-7. Paralegoceras Iowexse Meek and Worthen . . . . . . . . . . . . . . . . . . . . . . .

Lower Carboniferous, St. Louis-Chester stage, Bend formation, near Bend, San Saba County, Tex.

Figs. 4 and 5. Immature shell.

Fig. 6. Septa at this stage.

Fig. 7. Fnlargerl view of the shell at this stage.

Note.-Figs. 1-3 are from Second Ann. Rept. Geol. Surv. 'Texas, tigs. 57-59 (p. 355).

Figs. 4-7 are from Fourth Ann. Rept. Geol. Surv. Texas, figs. 52-55 (p. 474).

Itit' 

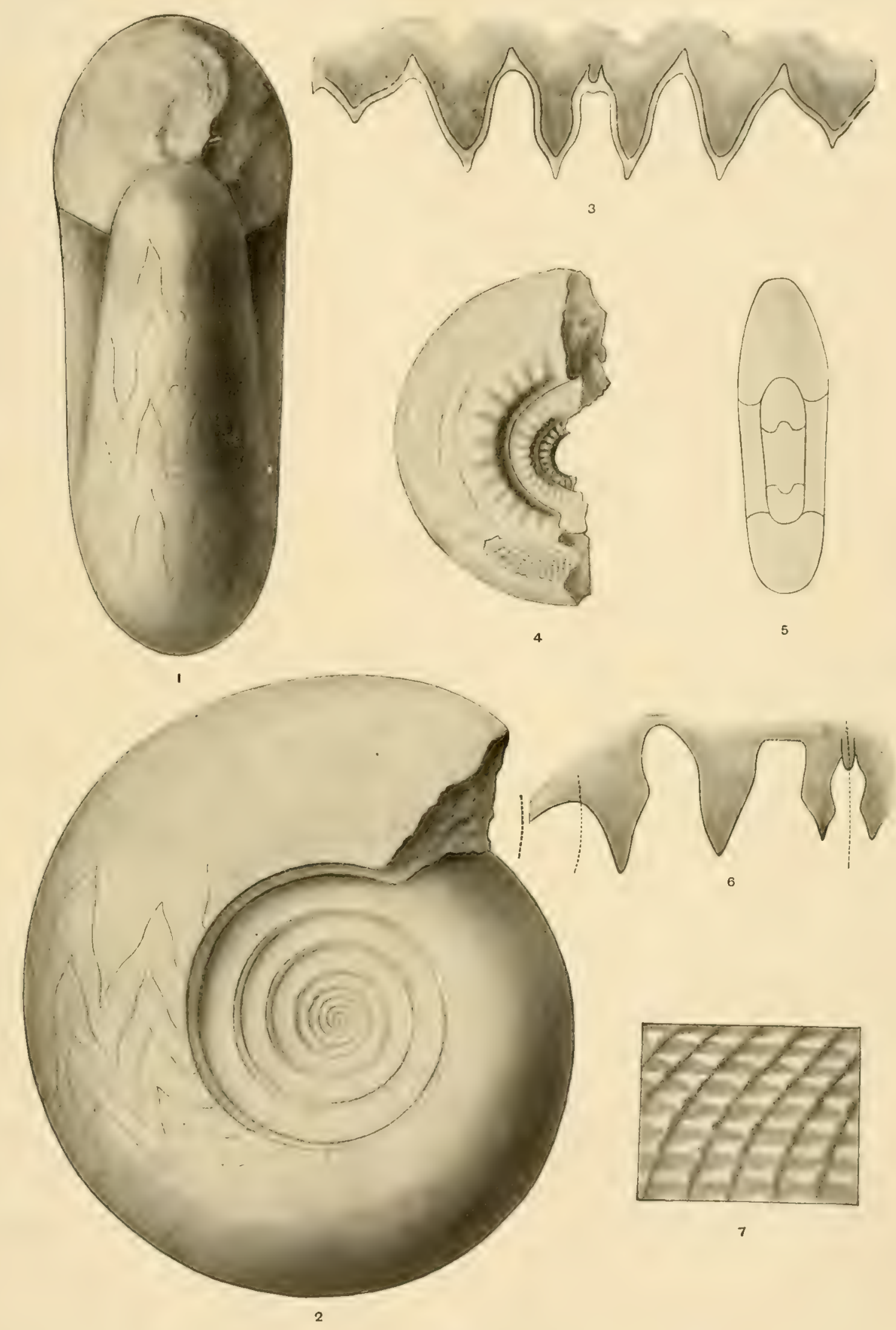

PLATE X. 


\section{PLATE $\mathrm{X}$.}

Figs, 1-11. Goniatites striates Sowerby (=Glyphioceras cumminsi Hyatt) ................ Lower Carboniferous, St. Louis-Chester stage, Bend formation, 5 miles west of Lampasas, Tex.

Figs. 1 and 2. Adolescent stage.

Fig. 3. Shell at this stage.

Figs. 4 and 5. Early adolescent stage.

Fig. 6. Shell at this stage.

ligs. 7 and 8. Early adolescent stage.

Figs. 9 and 10. Fully matured stage.

Fig. 11. Shell at this stage.

Figs. 12-16. Goniatites crenistria Phillips (=Glyphioceras incisum Hyatt) ..... . . . . . . . . .

Lower Carboniferous, St. Louis-Chester stage, Bend formation, near Richland Springs, San Saba County, Tex.

Figs. 12 and 13. Larly adult stage.

Figs. 14 and 15. Cross stria on niature shell.

Fig. 16. Restoration of the form after fig. 15.

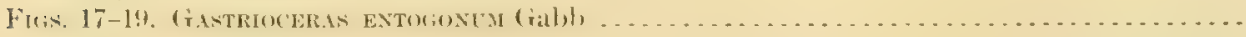

Lower Carboniferous, St. Louis-Chester stage, Bend formation, 5 miles west of Lampasas, Tex.

Figs. 17 and 18. Front and side view.

Fig. 19. Shell enlarged.

Noте - This plate is taken from Fourth Ann. Rept. Geol. Surv. Texas, P1. XLVII. 

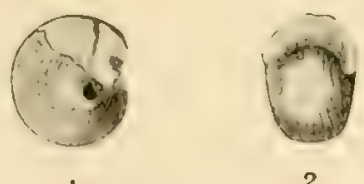

2
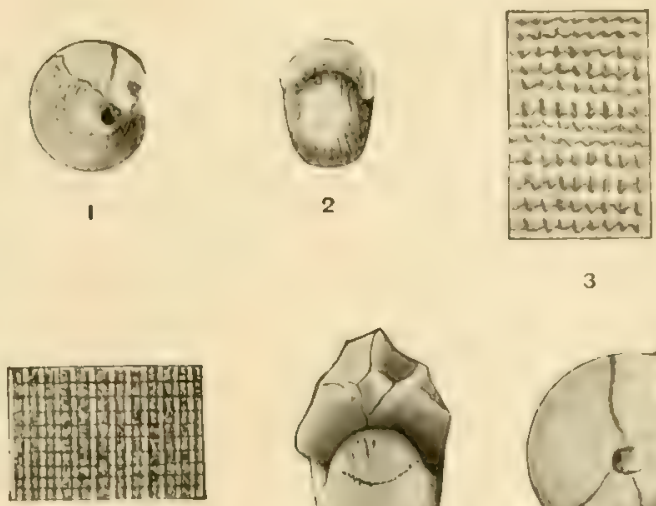

6
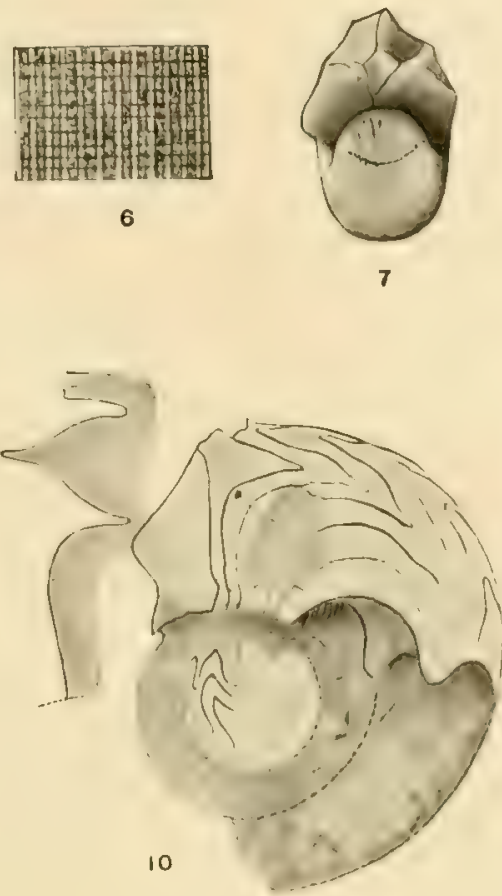
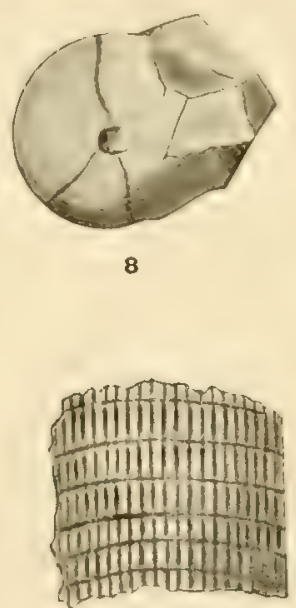

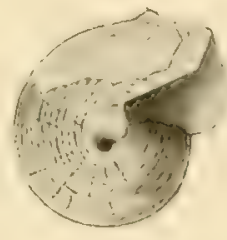

4

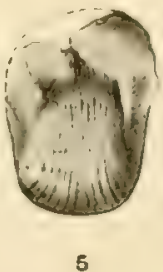

5

I I
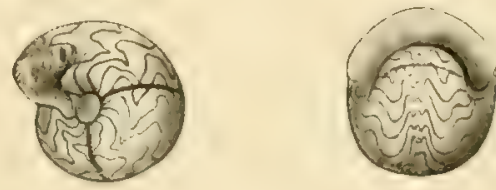

13

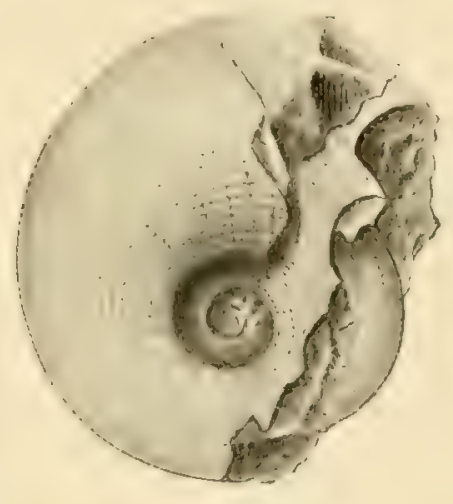

9

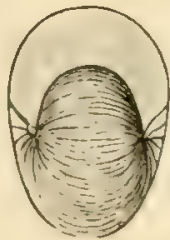

16
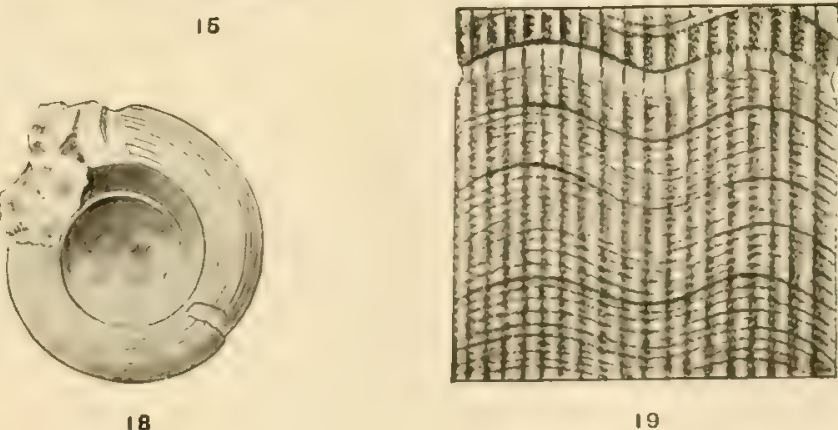



\section{PLATE XI.}




\section{PLATE XI.}

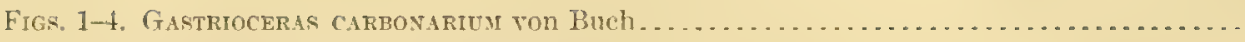

Middle Coal Measures, near Boles, Scott County, Ark.

Fig. 1. Side view of a composite artificial cast, from three specimens.

Fig. 2. Side riew of a septate fragment.

Fig. 3. Cross section of whorl.

Fig. 4. Sutures.

Figs. 5-7. Pronorites simbextifali Smith, sp. nov.

Middle Coal Measures, near Boles, Scott County, Ark.

Fig. 5. Side view of septate fragment.

Fig. 6. Cross section of whorl.

Fig. 7. Sutures.

Figs. 8-13. Gastrioceras BRANneri Smith

Lower Carboniferous, Chester stage, Pilot Mountain, Carroll County, Ark.

Fig. 8. Side view.

Fig. 9. Front view.

Fig. 10. Rear view.

Fig. 11. Cross section.

Fig. 12. Sutures of adult, twice enlarged.

Fig. 13. Sutures at diameter $23 \mathrm{~mm}$., twice enlarged. spec: Nat. IIus.

Tote.-Figs. 1-7 formed Pl. XX, Proc. Am. Philos. Soc, Tol. XXXV.

Figs. 8-13 formed part of Pl. XXIII, Proc. Am. Philos. Soc, Vol. XXXV. 

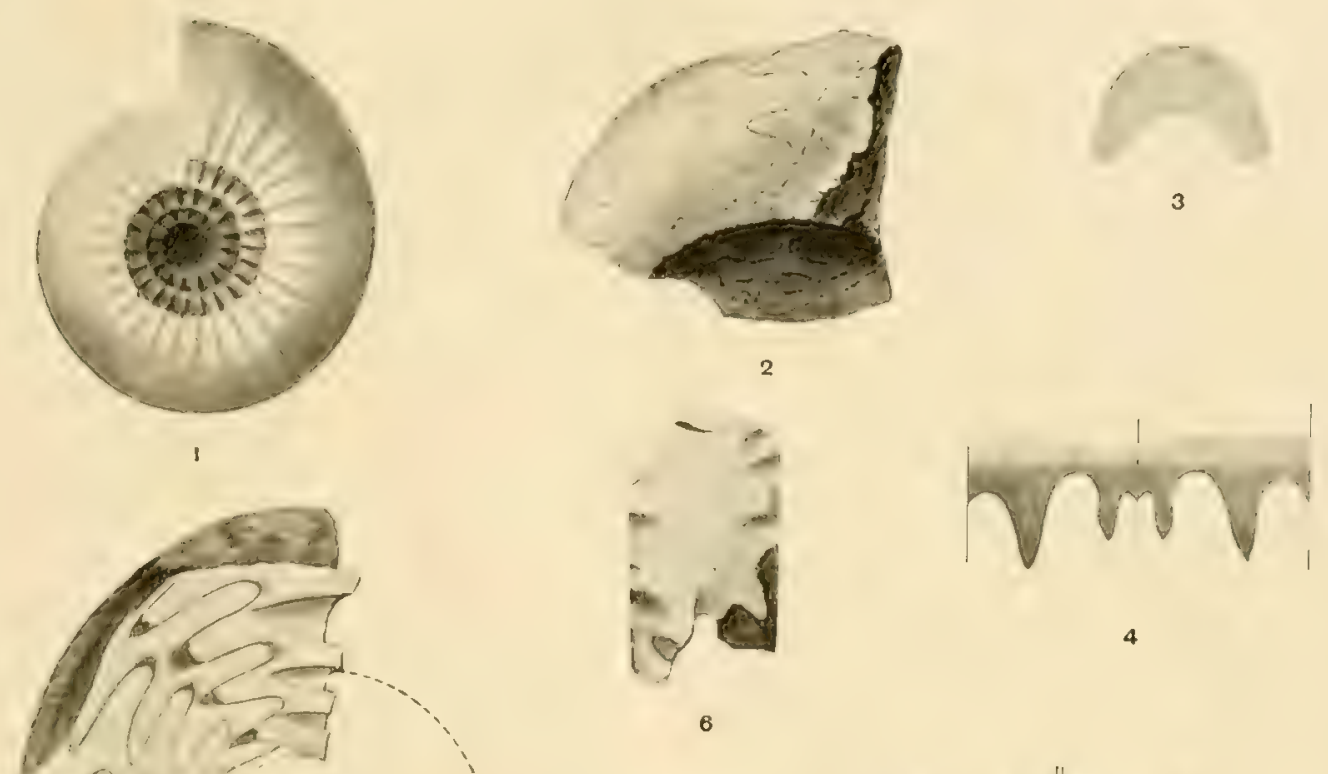

$\int f(L)$
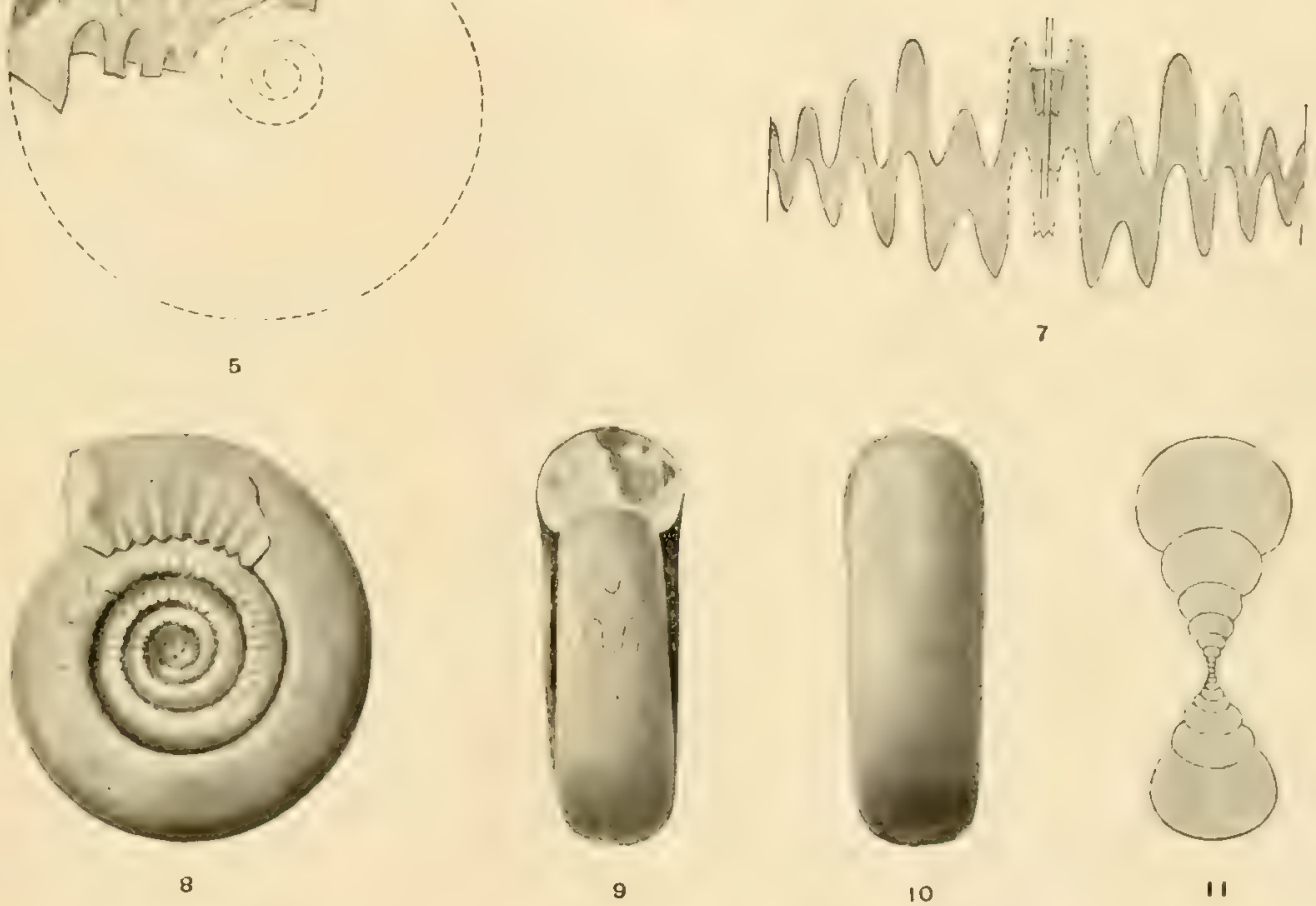

I I
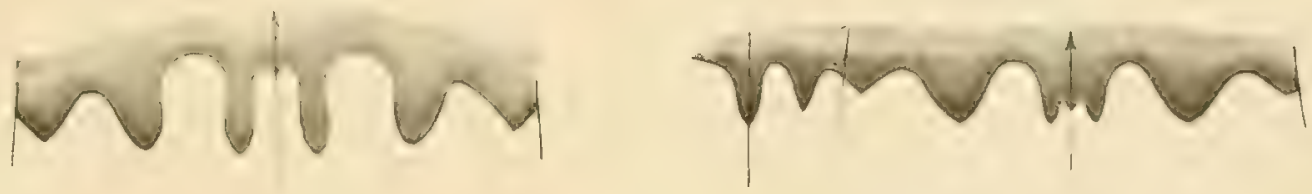

12 

PLATE XII. 


\section{PLAT'E XII.}

Figs. 1, 2. Proxorttas prepermict's Karpinsky (to minw the young stages)

Fig. 1. First two sutures.

Fig. 2.. Embryo chamber.

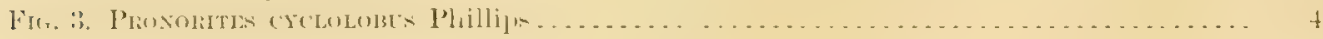

Fig. 3. Sutures, twice enlarged.

Figs 4-9. Paralegoceras newsomi Smith sp. now

101

Lower Coal Measures, Morrillton, Ark.

Fig. 4. Side view, partly restorerl.

Fig. 5. Front view.

Fig. 6. Side view of inner whorl taken out of the large specimen shown in fig. 1 .

Fig. 7. Front view.

Fig. 8. Sutures taken from the inner whorl of $25 \mathrm{~mm}$. diameter.

Fig. 9. Sutures on the outer whorl.

Fif. 10. GLYPHOCERAs DIADEMA Goldfuss, showing development of the sutures

1. First suture.

b. Second suture.

c. Third suture.

d. At $1.25 \mathrm{~mm}$. diameter.

e. At $2.25 \mathrm{~mm}$.

f. Adult.

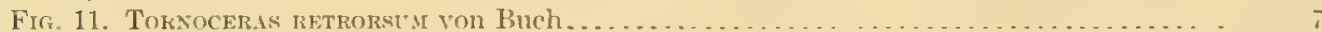

๙. First suture.

b. Second snture.

c. At $1.75 \mathrm{~mm}$. diameter.

d. At $2.50 \mathrm{~mm}$.

e. At $10 \mathrm{~mm}$., adult.

Figs. 12-15. Pronorites crclolobl's Phillips variety arkansasexsis Smith ................

Lower Carboniferous, Chester stage, Pilot Mountain, Carroll County, Ark.

Fig. 12. Side view.

Fig. 13. Rear view.

Fig. 14. Front view.

Fig. 15. Sutures.

ipec. Nat. Mus.

Note.-Figs. 1-3 were part of PI. XXIII, Proc. Am. Philos. Soc., Vol. IXXV; figs. 1 and 2 are after Karpinsky, Ammoneen der Artinsk-Stufe, Pl. I, fig. 2, e, f, g; fig. 3 is after Phillips, Geol. Yorkshire, Pt. II, Pl. XX, fig. 42.

Figs. +11 were part of Pl. XIX, Proc. Am. Philos. Soc, Vol. XXXY; fig. 10 is atter Branco, Palaeontographica, Vol. XXVII, Pl. IV, fig. 1; fig. 11 is after Branco, Paleontographica, Vol. XXVI, Pl. V, fig. 7.

Figs. 12-15 were part of Pl. XXIV, Proc. Am. Philos, Soc, Vol. XXXV. 

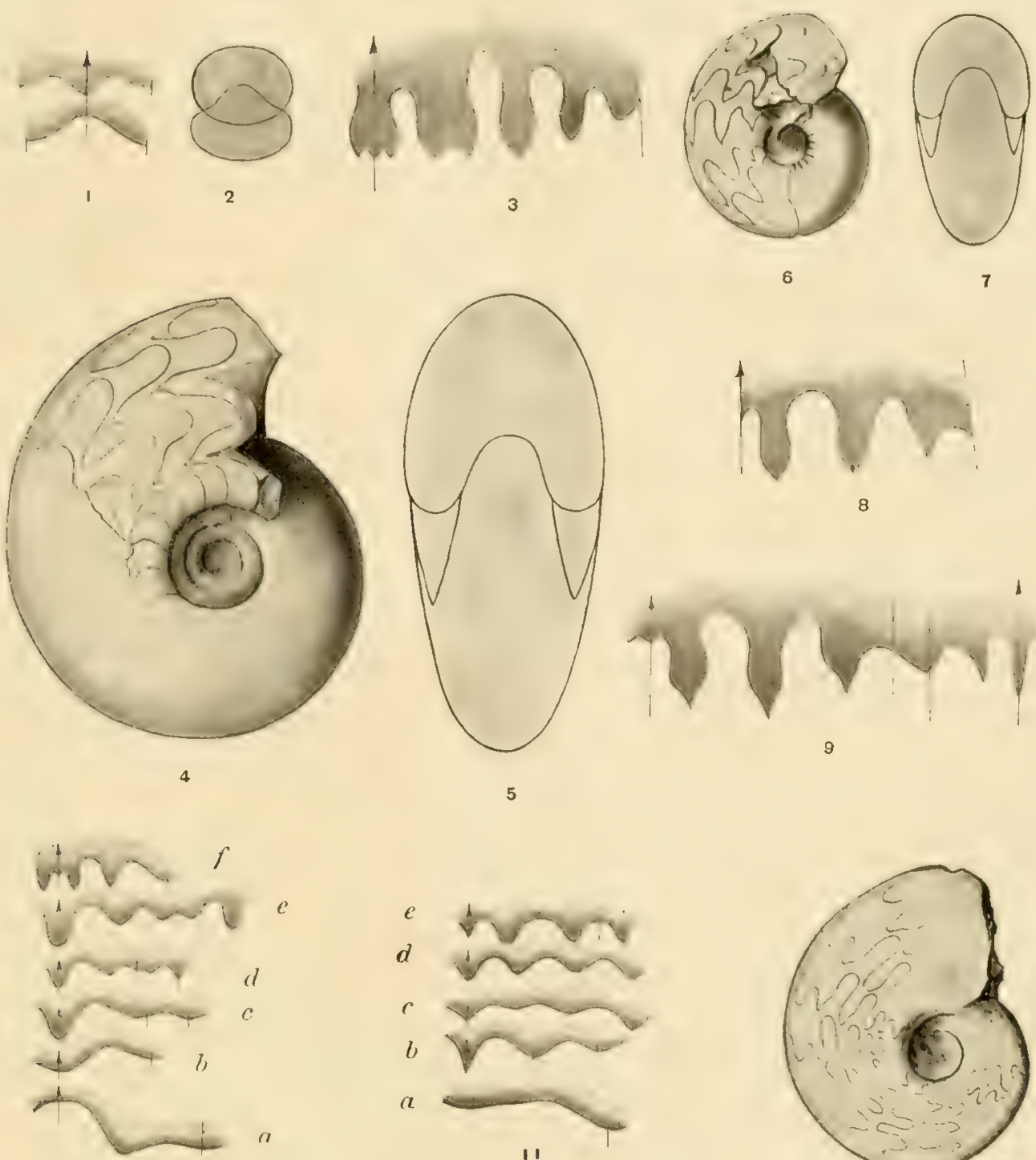

10
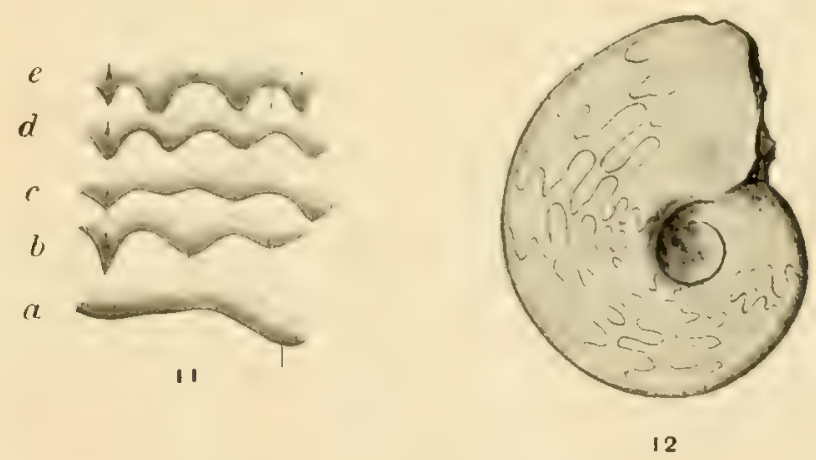

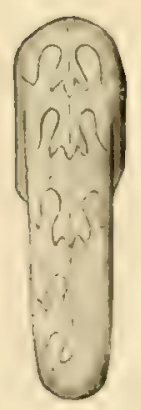

13

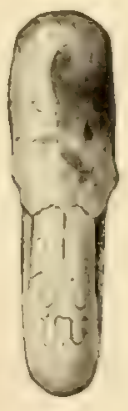

14

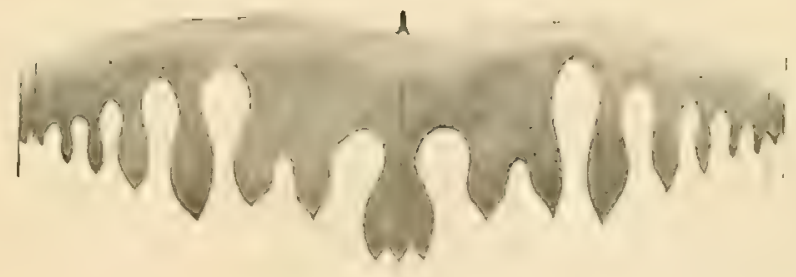

15 

PLATE XIII. 


\section{PLATE XIII.}

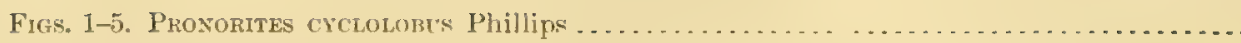

Ural Mountains.

Fig. 1. Side view.

Fig. 2. "Cross section of a volution, Mergicenas stage."-Karpinsky.

Fig. 3. "Cross section of a volution, Paraprolecanites stage."-Karpinsky.

Fig. 4 , a, b. Natural size.

Fig. 5, a-f. Showing development of the sutures, from the Ibergiceras to the Promorites stage.

Figa. 6-15. Gastrioceras Listeri Martin

Middle Coal Measures, Boles, Ark.

Fig. 6. Side view.

Fig. 7. Rear view,

Fig. 8. Front view. Artificial cast, magnified twice.

Fig. 9. Side view.

Fig. 10. Side view, largest specimen.

Fig. 11. Cross section of whorl.

Fig. 12. Artificial cast.

Figs. 13-15. Development of the sutures.

Хоте.-Figs. 1-5 formed part of Pl. XXIV, Proc. Am. Philos. Soc., Vol. XXXV, from Ammoneen der Artinsk-Stufe, Pl. I.

Figs. 6-15 formed Pl. XVI, Proc. Am. Philos. Soc., Vol. XXXV. 


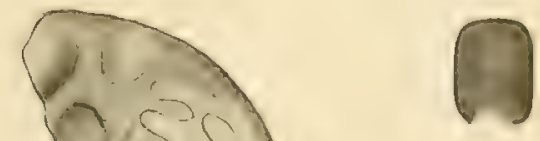

2
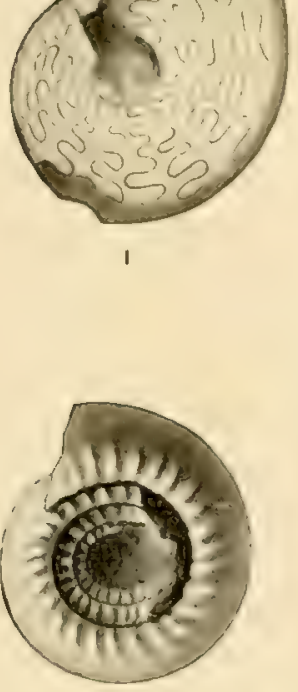

6

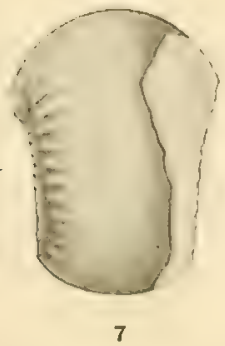

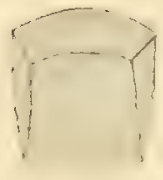

8 ax + voulog d wang $c$ $\operatorname{lon} a$

5

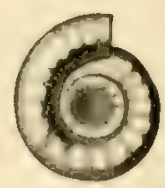

9

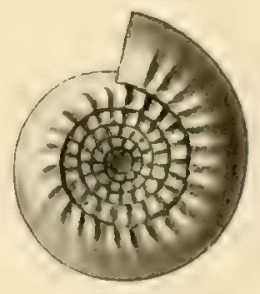

12

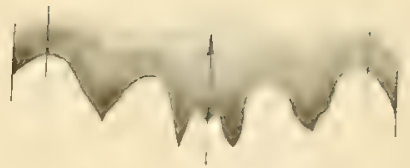

13

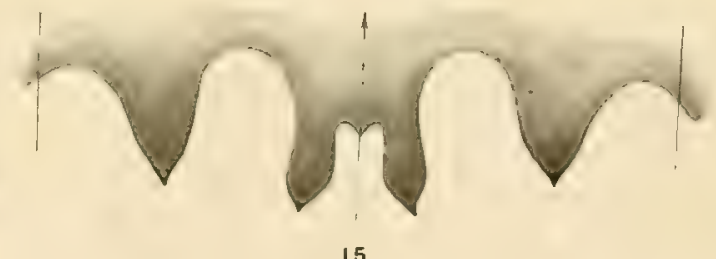





\section{PLATE XIV.}




\section{PLATE XIV.}

(All figures on this plate are forty times enlarged.)

Figs. 1, 2, Protoconch.

Fig. 1. From above.

Fig. 2. From front; diameter $0.46 \mathrm{~mm}$.

Figs. 3-5. Protoconch of same or a nearly related species from Scott County, Ark.

Fig. 3. From above.

Fig. 4. From front.

Fig. 5. From side.

Figs. 6-8. Protoconch with first two sutures.

Fig. 6. From above.

Fig. 7. From front.

Fig. 8. From side.

Figs. 9, 10. Larval stage, diameter of $0.74 \mathrm{~mm}$, protoconch and one-half of first whorl, showing the first four sutures, from phylembryonic to the paranepionic substage.

Fig. 9. From side.

Fig. 10. From front.

Figs. 11, 12. Larval stage, diameter of $0.92 \mathrm{~mm}$., first whorl, showing first eight sutures, and transitions from the metanepionic (Anarcestes stage), through paranepionic (Paroloceras stage) to ananeanic (Prionoceras) stage.

Fig. 11. From front.

Fig. 12. From side.

Note.-This was Plate XIII, Proc. Cal. Acad. Sci., 3 series, Geology, Vol. I.

All specinens figured on this plate, except figs. $3,4,5$, came from the Lower Carboniferons, St. Lonis-Chester stage, Moorefield, Ark. 

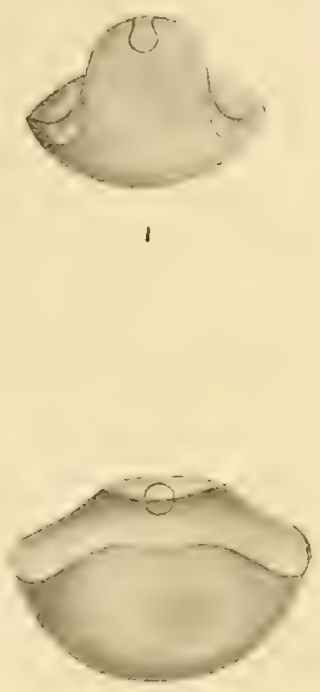

4
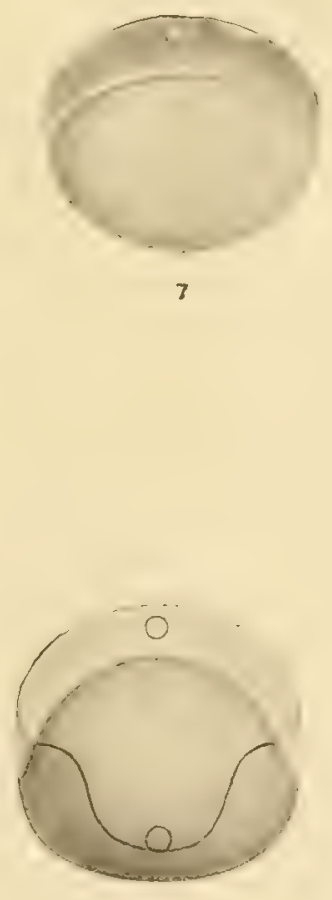

10
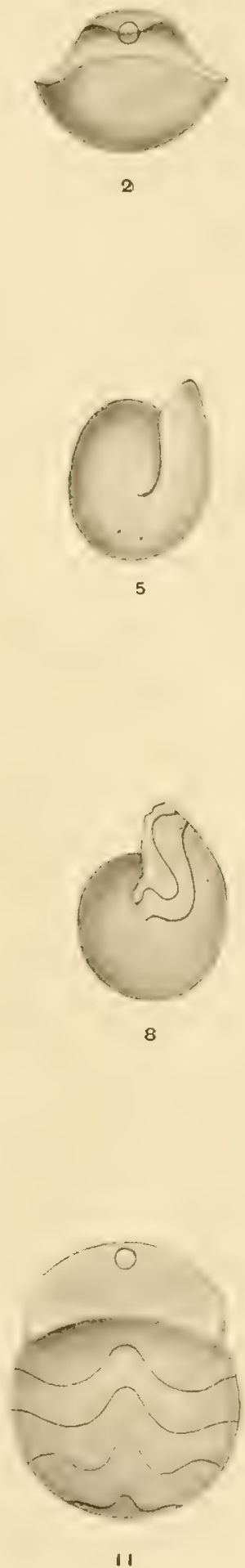
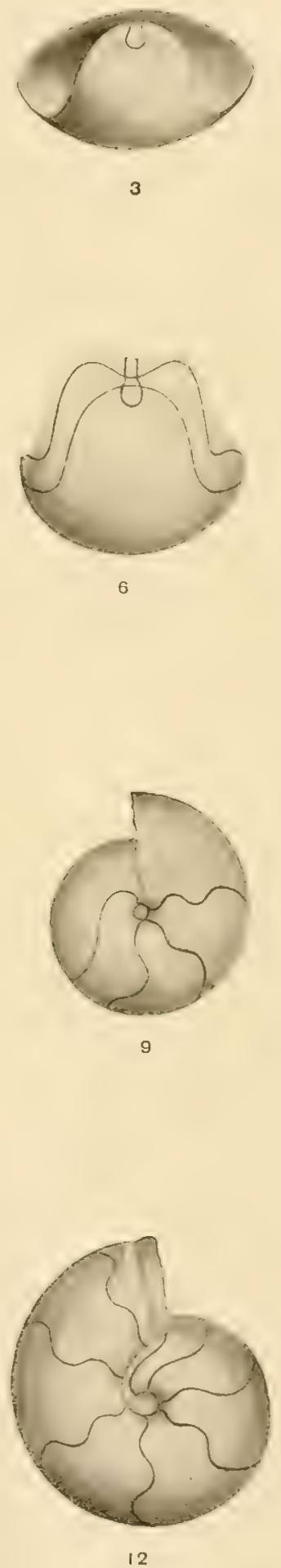



\section{PLATE XV.}

MON XLII-112- 12 


\section{PLATE XV.}

( 11 figures on this plate are twenty times enlarged, except fig.9, which is twice natural size.)

GUNiatites cRenistria Phillips

Figs. 1, 2. Adolescent stage, $1 \frac{3}{4}$ whorls, diameter of 1.29 mm., last whorl is ananeanic (Prionocercs stage) and shows transition from paranepionic.

Fig. 1. Front.

Fig. 2. Sicle.

Figs, 3, 4. ddolescent stage, diameter of 1.37 mm., 17 whorls, Primocems stage.

Fig. 3. From front.

Fis. t. From side.

Fips 5, 6. Adolescent stage, diameter of 1.64 mm., :28 whorls, Prionocems stage.

Eig. 5. From front.

Fig. 6. From side.

Figs. 7, 8. End of adlolescent stage, diameter of $2.25 \mathrm{~mm}$; $2 \frac{3}{4}$ whorls; transition from Prionoceres to Gomiatites in the division of the ventral lobe, and beginning rounding of the whorl.

Fing. 7. From front.

Fig. 8. From side.

Fig. 9. Farly aclult stage, liameter of $15 \mathrm{~mm}$.

Nots.-This was Pl. XIV, Proc. Cal. Acad. Sci., 3d series, Geology, Vol. I. All specinens tigured on this plate came from the Lower Carboniferous, St. Louis-Chester stage, Moorefield, Ark. 

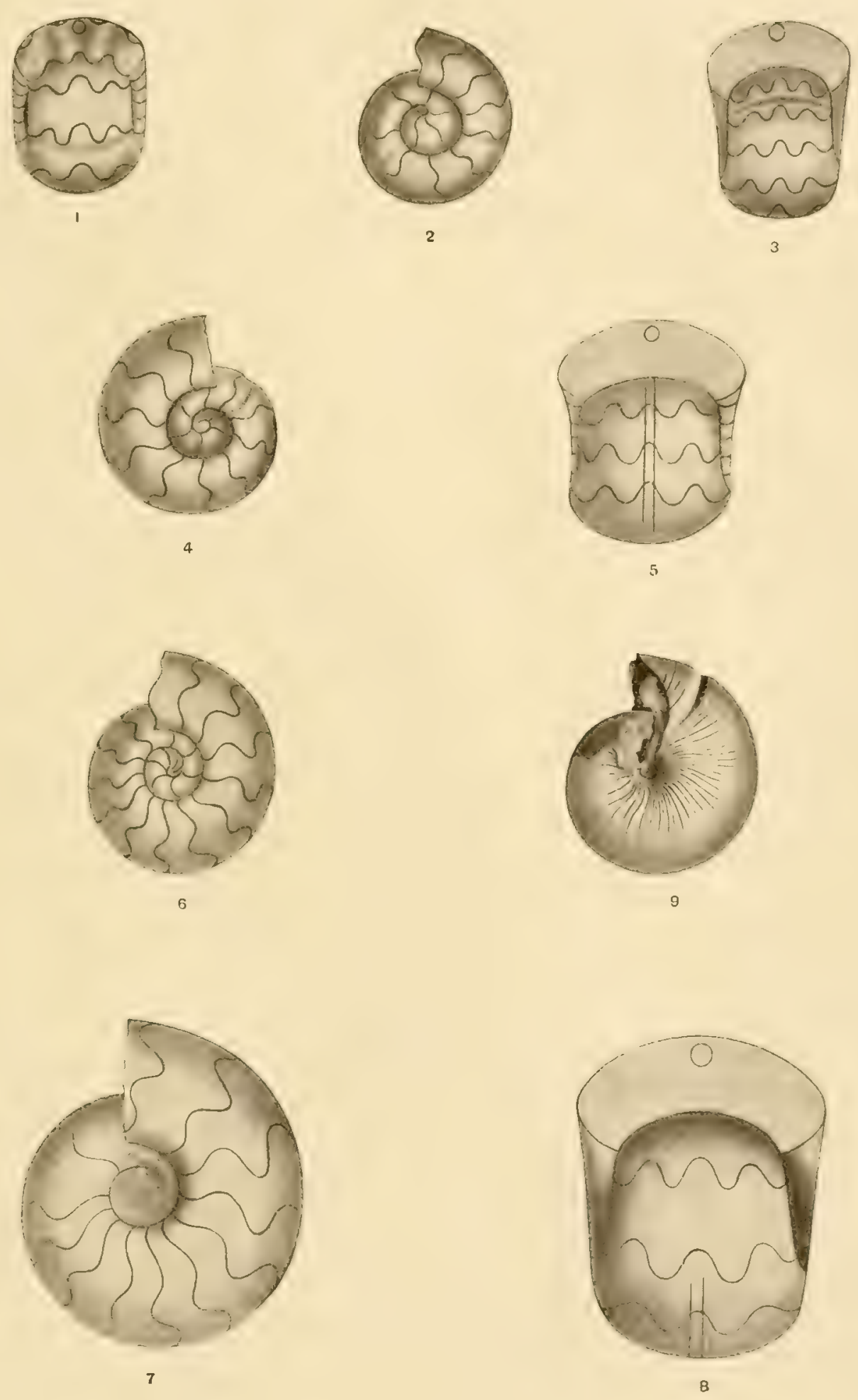

PLATE XVI. 


\section{PLA'TE XVI.}

Fig. 1. Goniatites Crenistma Phillips, showing development of septa

Page.

Lower Carboniferous, St. Louis-Chester stage, Moorefield, Ark.

$6 s$

a. First septum, ananepionic.

b. Second septum, metanepionic.

c. Third septum, metanepionic:

d. Fourth septum, paranepionic.

e. Fifth septum, one-half revolution, diameter $0.74 \mathrm{~mm}$., paranepionic.

f. Eighth septum, one revolution, diameter $0.92 \mathrm{~mm}$, ananeanic (Prionoceras).

g. Ananeanic septum, $1 \frac{3}{4}$ revolutions, diameter $1.29 \mathrm{~mm}$.

$h$. Septum at $1 \frac{7}{6}$ whorls, diameter $1.37 \mathrm{~mm}$.

i. Septum at $2.25 \mathrm{~mm}$., 23 revolutions, transitional from Prionoceras to Goniatites.

$j$. Septum at $15 \mathrm{~mm}$., early adult. All figures magnified 20 times, except $j$, which is twice enlarged.

Fig. 2. Gastrioceras excelsum Meek

Middle Coal Measures, Pope County, Ark.

vi. Septa.

b. Cross section of whorl.

Fir. 3. Munssteroceras parallelum Hall

Lower Carboniferous, Kinderhook stage, Rockford, Ind.; septa natural size.

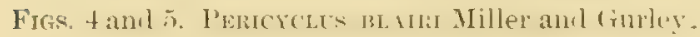

Lower Carboniferous, Kinderhook stage, Sedalia, Mo.

Figs. 6-8. MLlleroceras Parrismi Miller and Gurley

Upper Coal Measures, Kansas City, Mo.

Fisim. 9-11. Neoicoceras Elghorsexse Miller and Gurley

Midkle Coal Measures, Elkhorn Creek, Kentucky.

Figs. 12-14. Gistroceris montgoneryexse Miller and Gurley.

Upper Coal Measures, Montgomery County, Ill.

Figs, 15-17. Scuistoceras fultoxexse Miller and Gurley

Upper Coal Measures, Fulton County, Ill.

Fict. 18. Septa of Prolecanites Lyosi Meek and Worthen..............................

Lower Carboniferous, Kinderhook stage, Rockford, Ind.

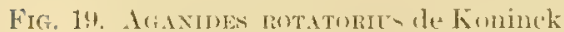

Lower Carboniferous, Kinderhook stage, Rockford, Ind.

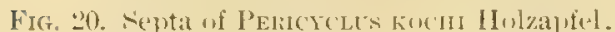

Lower Carboniferous, Tournaisian stage, Erdbach, Germany.

Fic. 21. Septa of Popanoceras parkeri Heilprin

Middle Coal Measures, Strawn formation, Wise County, Tex.

Note.-Figs 4-17 loaned by the University of Chicago, from Bull. Illinois State Mus. Nat. His., No. 11.

Fig. 18 is after Frech, Die Steinkohlenformation, Pl. ILVI, A, fig. 11.

Fig. 20 from Pal. Abhandl., Vol. V, Pl. III, fig. 6.

Fig. 21 is from Proc. Acad. Sci. Phila., 188t, p. 53.) 


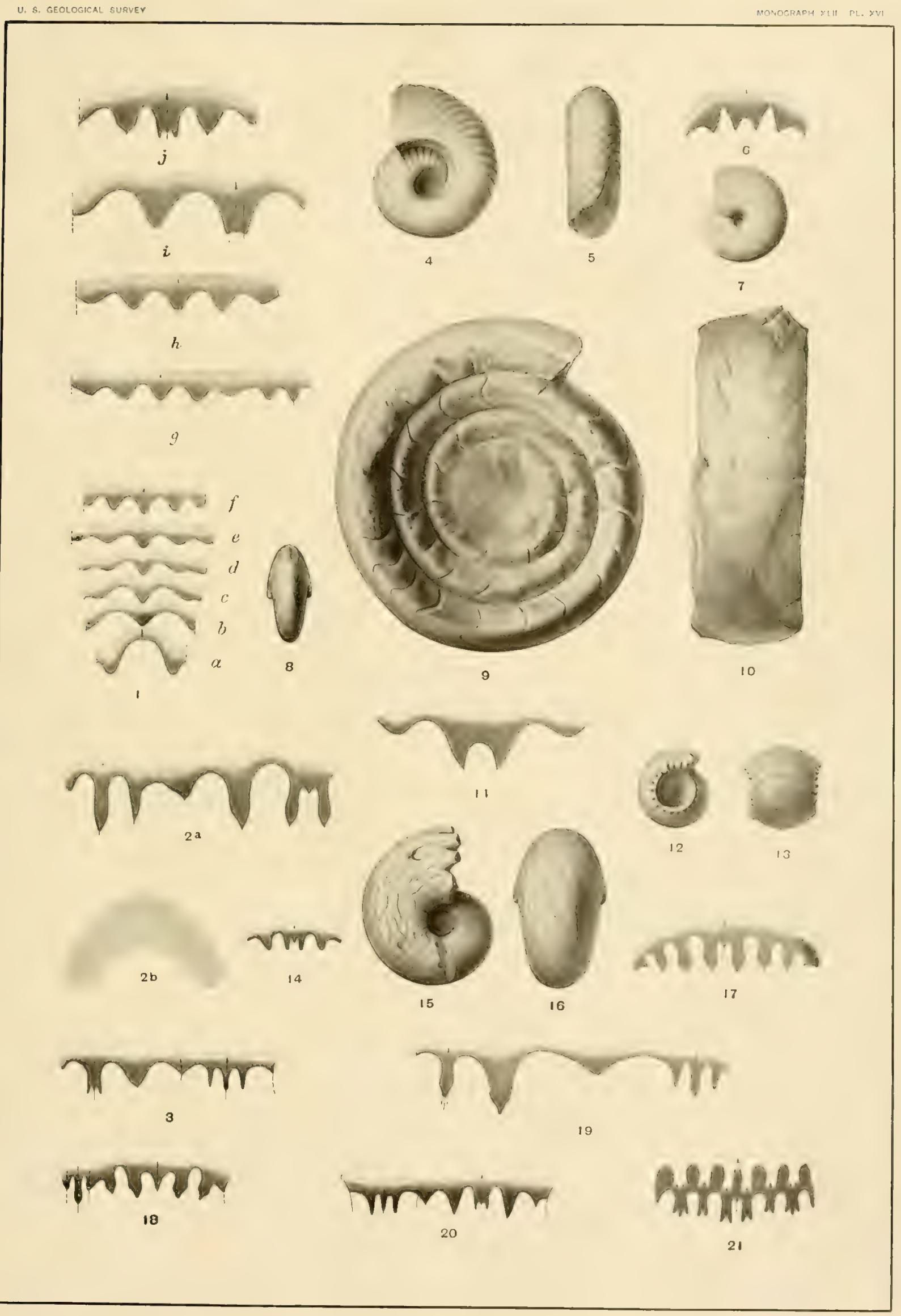



PLATE XVII. 


\section{PLATE XVII.}

Fro. 1. (roviatites kentuckingas Miller

Lower Carboniferous, Crab Orehard, Ky:

Ficis, 2-5.). Gosiatites sew,

Lower Carboniferous, St. Louis-("hester stage, Batesville, Ark.

Figs. 2, 3. Natural size.

Fig: 4. Inner coil of specimen shown in fig. 3; dianeter y um., 3 times enlarged.

Fig. 5. Three times enlargerl.

Fins, 6-8. Gastrioceras illixuisexse Miller and Gurley . . . . . . . . . . . . . . . . . . . . .

Upper Coal Measures, Montgomery County, III.

Figs. 9-11. Gastrincerds Kaxsisense Miller and (rurley.

Upper Coal Measures, Kansas City, Mo.

Fins. 12-14. Goximtites GRexcistuexsis Miller and Gurley

Lower Carboniferous, (ireencastle, Ind.

Figs, 15-17. Gastrioceras subcarta Miller and Gurley

Upper Coal Measures, Montgomery County, 111.

FIGs. 18-20. AgAxides JEssie. Jliller and fiurley.

Lower Carboniferous, Serlalia, MI\%.

Note-Figs, 1 and 6-20 loaned by the Univervity of Chicago, from Bull. Illinois State Mus. Nat. Hist. No. 11. 


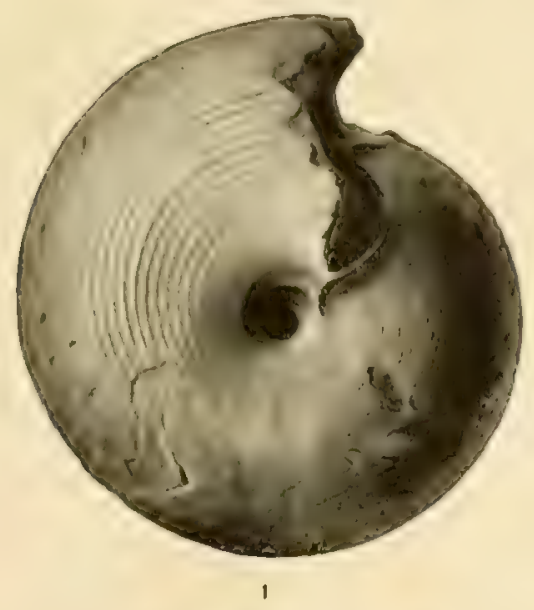

nime

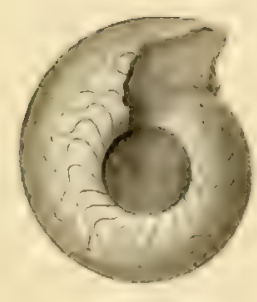

9
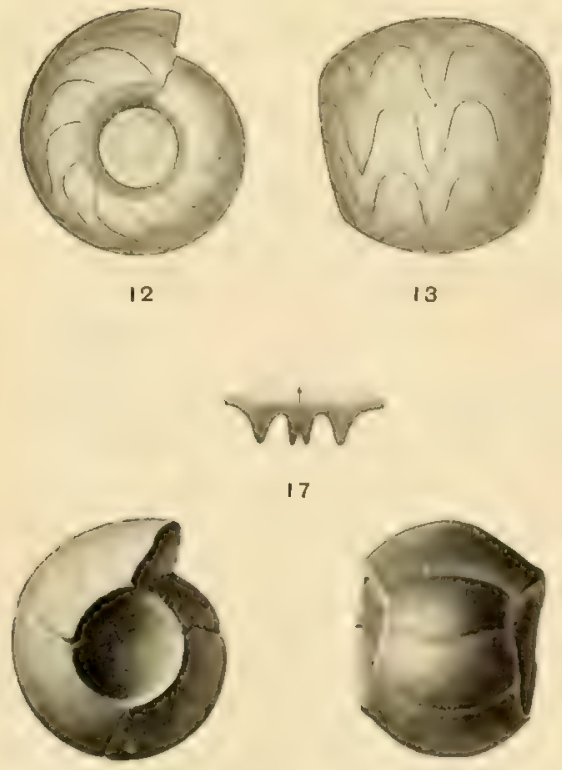

15
13

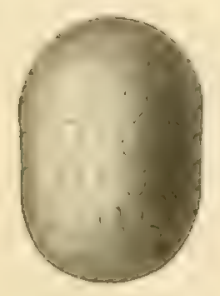

11

5
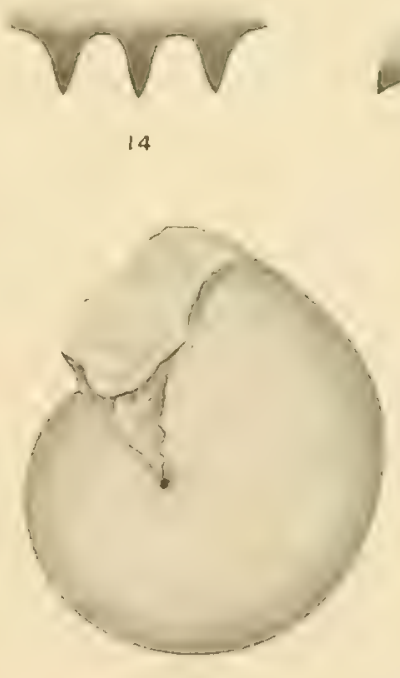

18
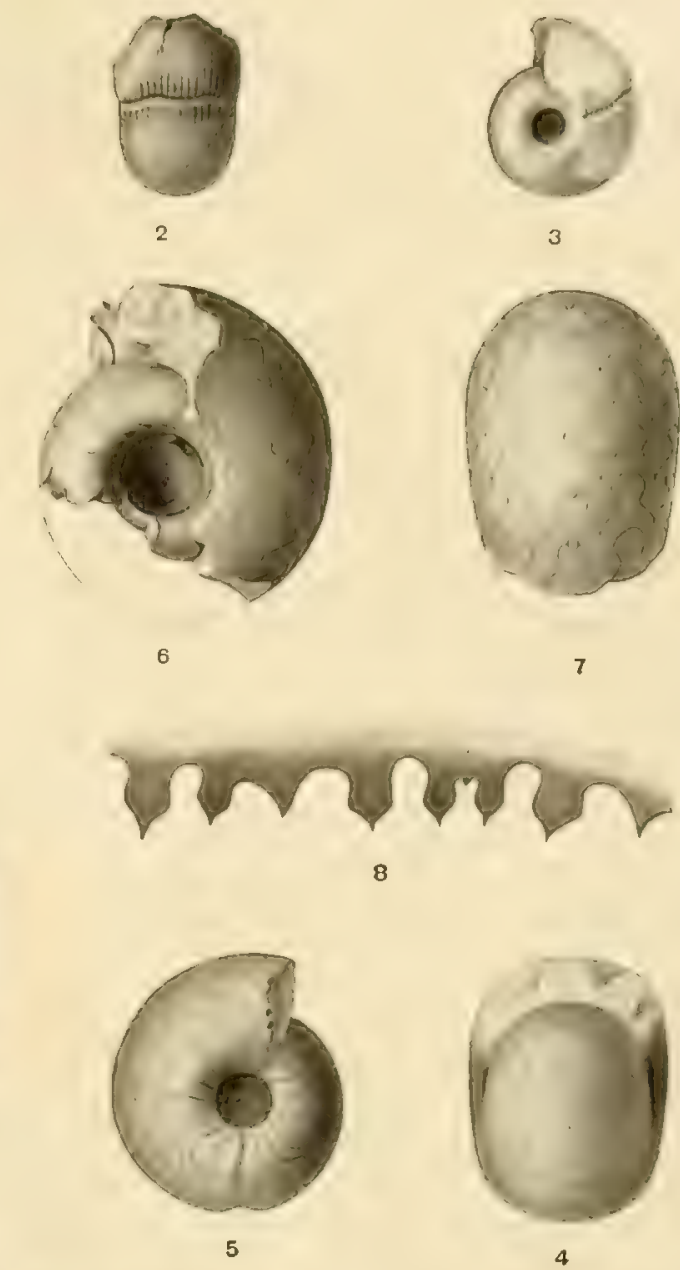

3

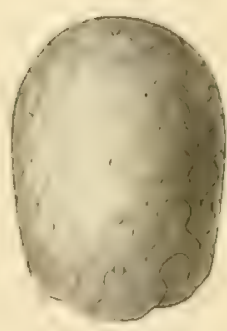

7

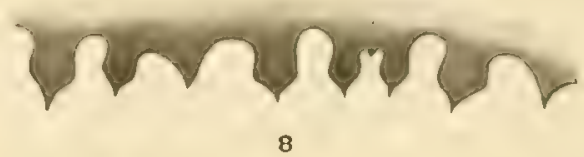

4
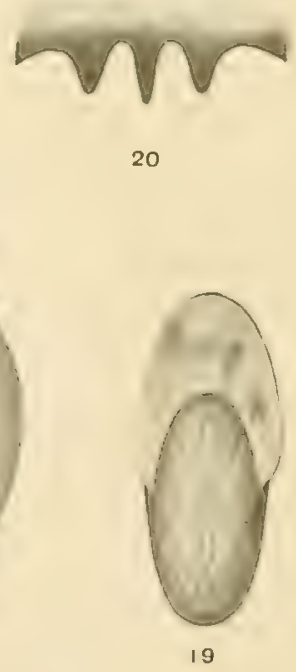



\section{PLATE XVIII.}




\section{PLA'TE XVIII.}

Pages.

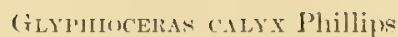

Lower Carboniferous St. Louis-Chester stage, Moorefield, Ark.

Figs. 1-3, Larval stace, diameter $0.98 \mathrm{~mm} ., 20$ times enlarged; corresponding to Parodoceras

Figs. 4 and 5. Early adolescent stage, corresponding to l'rionoceras; diameter $1.56 \mathrm{~mm}$., $1 \frac{2}{3}$ coils, 20 times enlargert.

Figs. 6-8. Later adolescent stage, transitional from Prionoceras to Gilyphiocerts; diameter $2.25 \mathrm{~mm} ., 3 \frac{1}{8}$ coils, 13 times enlarged.

Figs. 9-11. Mature stage, diameter $4.25 \mathrm{~mm} ., 4 \frac{1}{2}$ coils, 10 times enlarger.

1 ist 


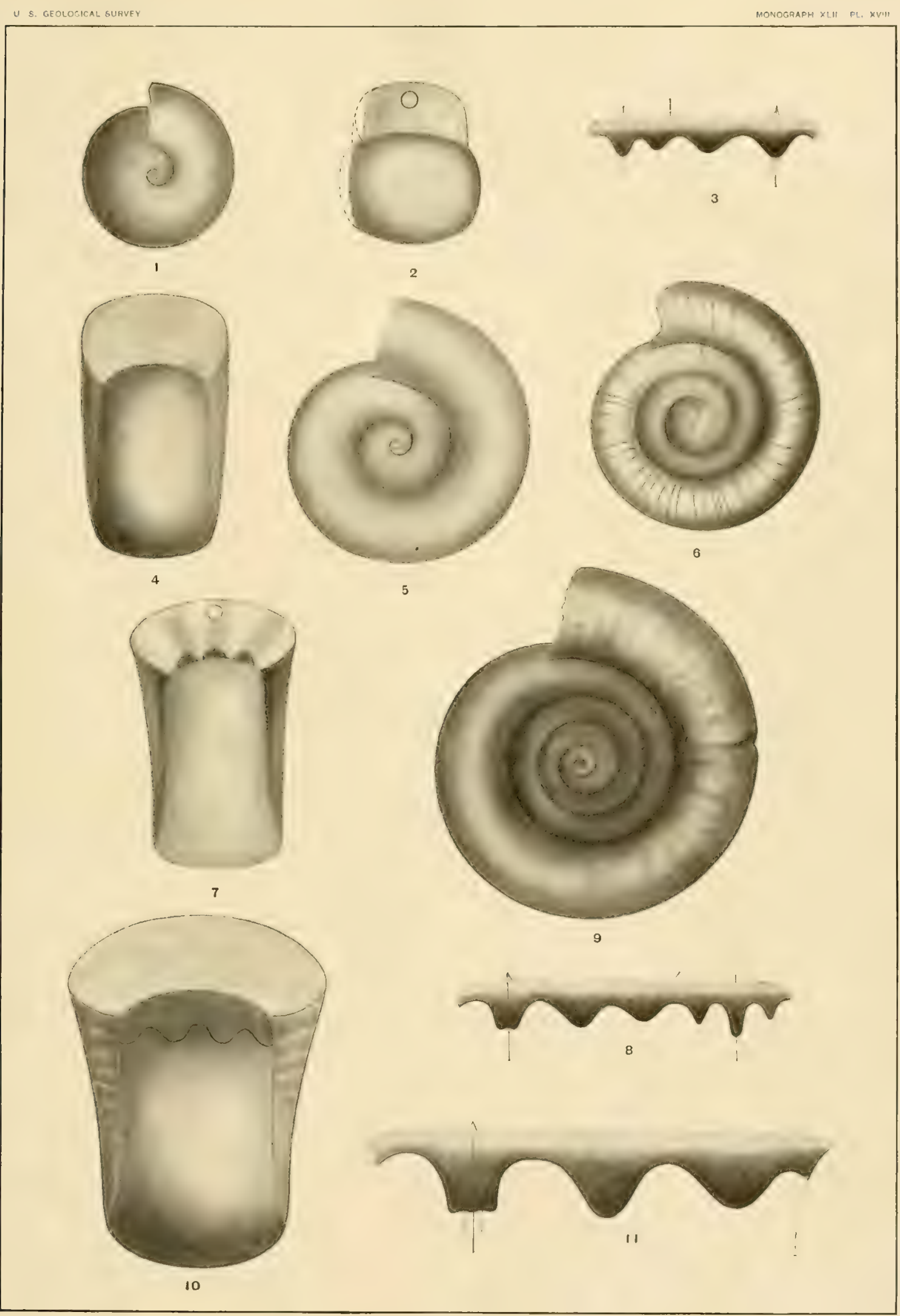





\section{PLATE XIX.}




\section{PI.ATE XIX.}

Figs, 1 and 2. Muensteroceras Parallelty Hall................................ 121

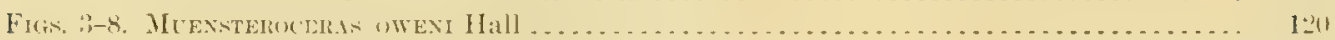

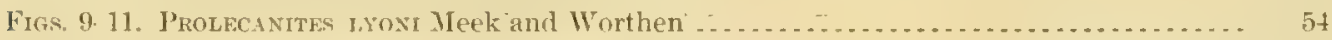

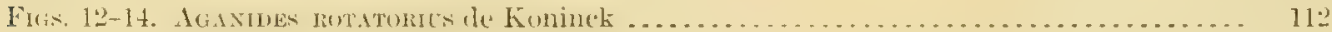

NoTE, - The figures on this plate are slightly reduced by photography from Pal. N. Y., Vol. V, Pt. II, Pl. LXXIII.

All specimens on this plate from the Lower Carboniferous, Kinderhook stage. goniatite bed, Rockford, Ind. 

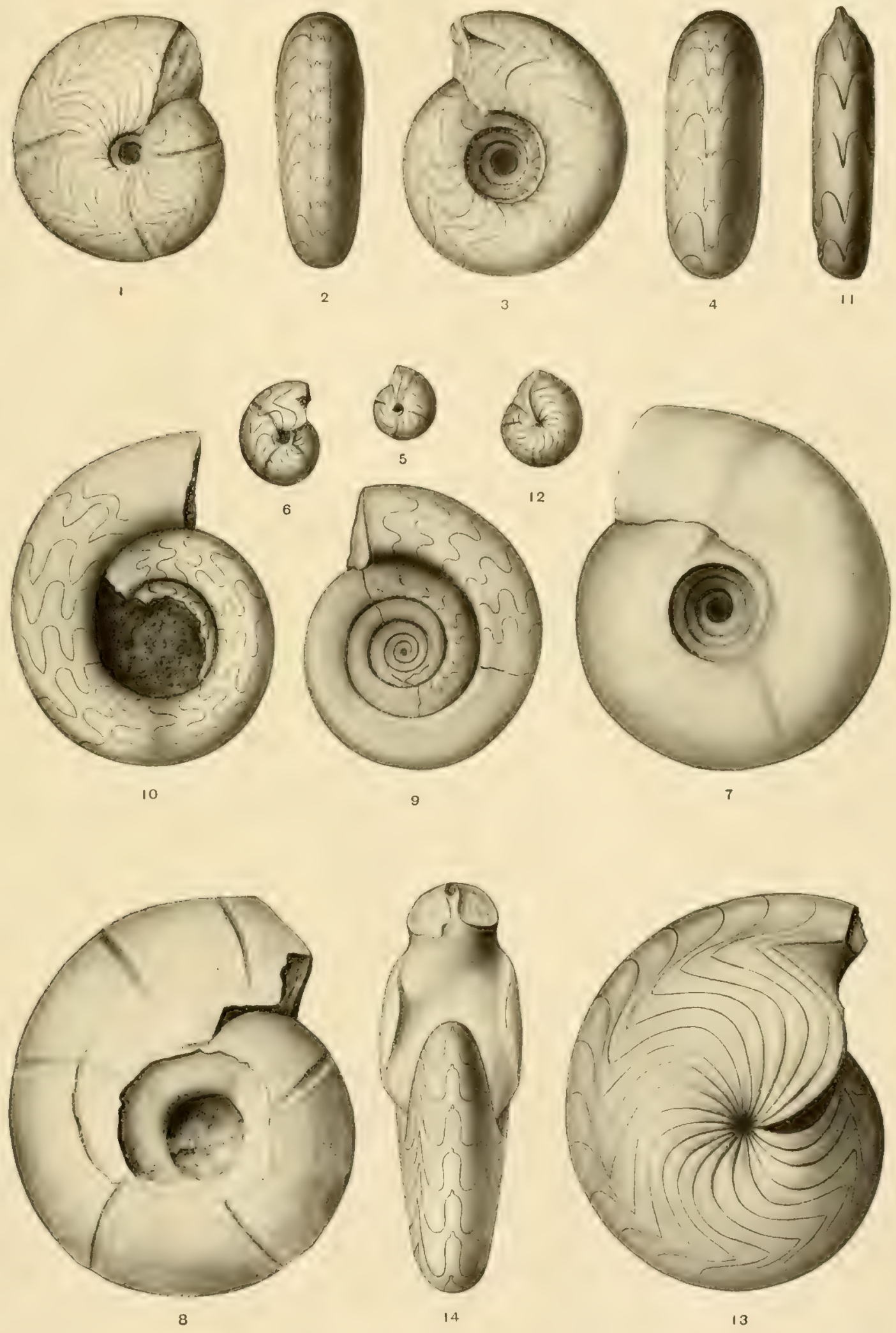



\section{PLATE XX.}




\section{PLATH XX.}

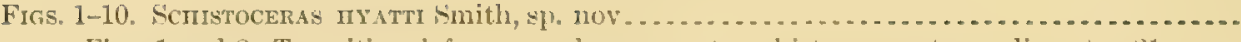

Figs. 1 and 2. Transitional from paralegoceran to schistoceran stage, diameter $21 \mathrm{~mm}$. twice enlarged.

Figs. 3 and t. barly adult, schistoceran stage, diameter $40 \mathrm{~mm}$., natural size, showing the surface of shell.

Figs. 5 and 6 . Adult stage, diameter 43 mm., natural size. This was Hyatt's type of the genus Schistoceras.

Figs. 7 and 8 . Adult stage, diameter $67 \mathrm{~mm}$, natural size.

Frgs. 9-11. Gonioloboceras welleri Smith, sp. nov . . . . . . . . . . . . . . . . . . . . . .

Adolescent, glyphioceran stage, diameter 7.5 mm., enlarged 5 times.

Figs. 12-15. Drmorphoceras Texanum Smith, sp. nov. (The cross section, tig. 13, is about

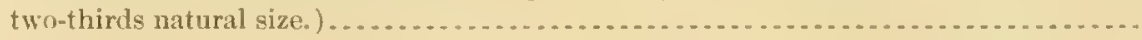

Nore.-All specimens on this plate from Upper Coal Measures, Cisco formation, (iraham, Young County, Tex. 


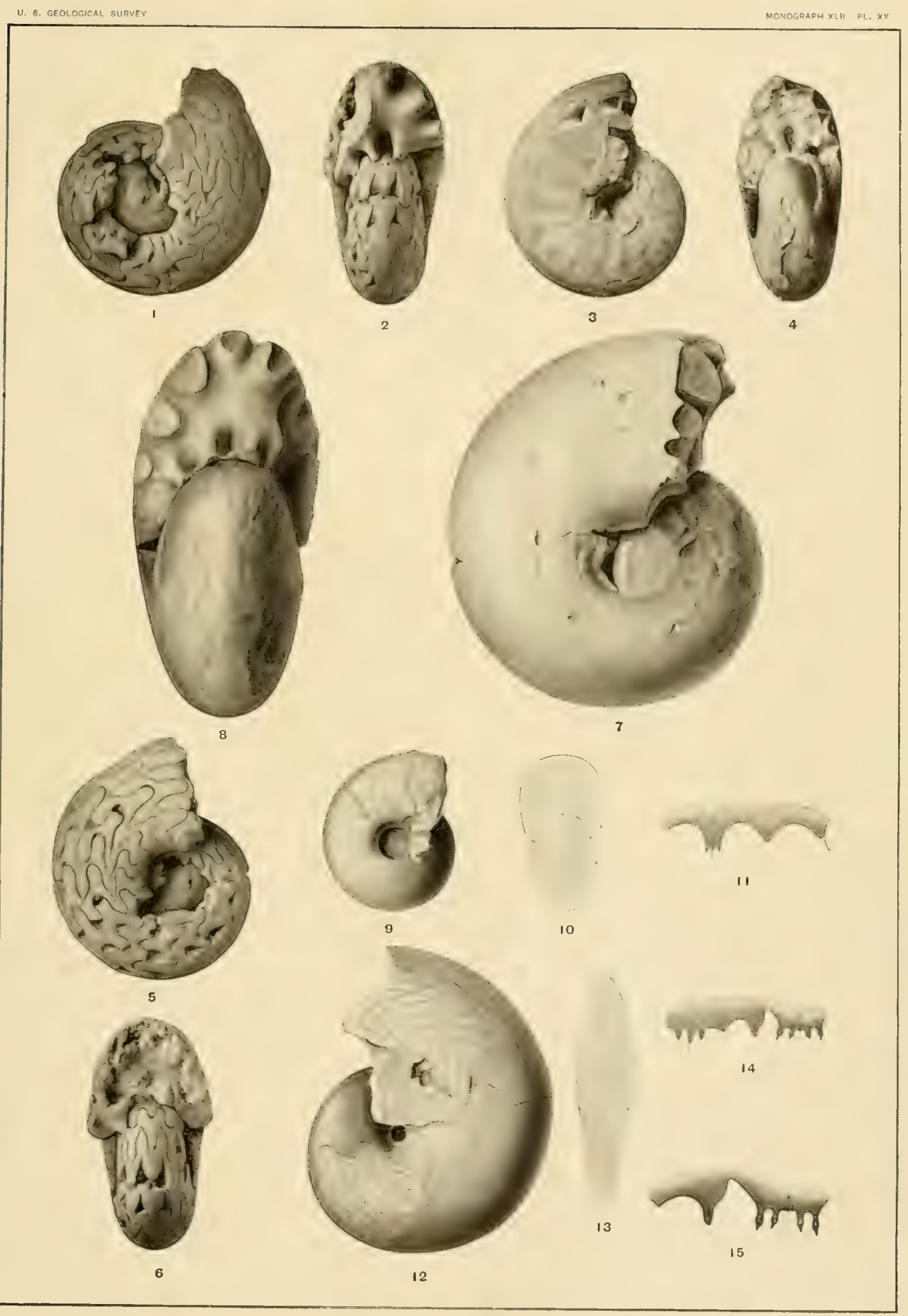



PLATE XXI. 


\section{PLATE XXI.}

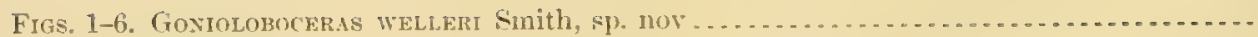

Natural size.

Figs. 1 and 2. Larly adolescent stage, with rounded abdomen.

Figs. 3 and 4 . Adult stage, with angular and slightly furrowed ablomen.

Fig. 5. External septa.

Fig. 6. Internal sentu.

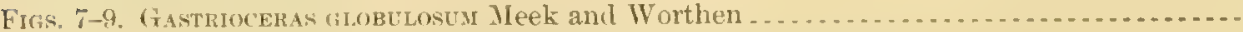

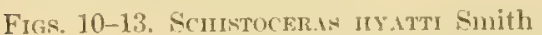

Fig. 10, a and b. Castrioceran stage, 4 times enlargenl; diameter $5.5 \mathrm{~mm}$.

Fig. 11, a, b, and c. Paralegoceran stage, 4 times enlarged; diameter $10.5 \mathrm{~mm}$.

Fig. 12. Septa transitional from paralegoceran to schistoceran stage; diameter $21 \mathrm{~mm}$; twice enlarged.

Fig. 13. Adult septa, diametex $42 \mathrm{~mm}$, natural size.

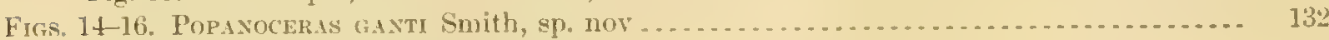

(The details of the internal septa, fig. 16 , could not be male out.)

Figs. 17-19. Agatmiceras cIscoense Smith, \$p. nov . . . . . . . . . . . . . . . . . . . . ..... 131

Figs. 20-22. Schuchegtites graman Smith, sp. nov . . . . . . . . . . . . . . . . . . . . . 50

Fоть-Allspecimens on this plate from the Upper Coal Measures, Cisco Iormation, Graham, Foung County, Tex. 

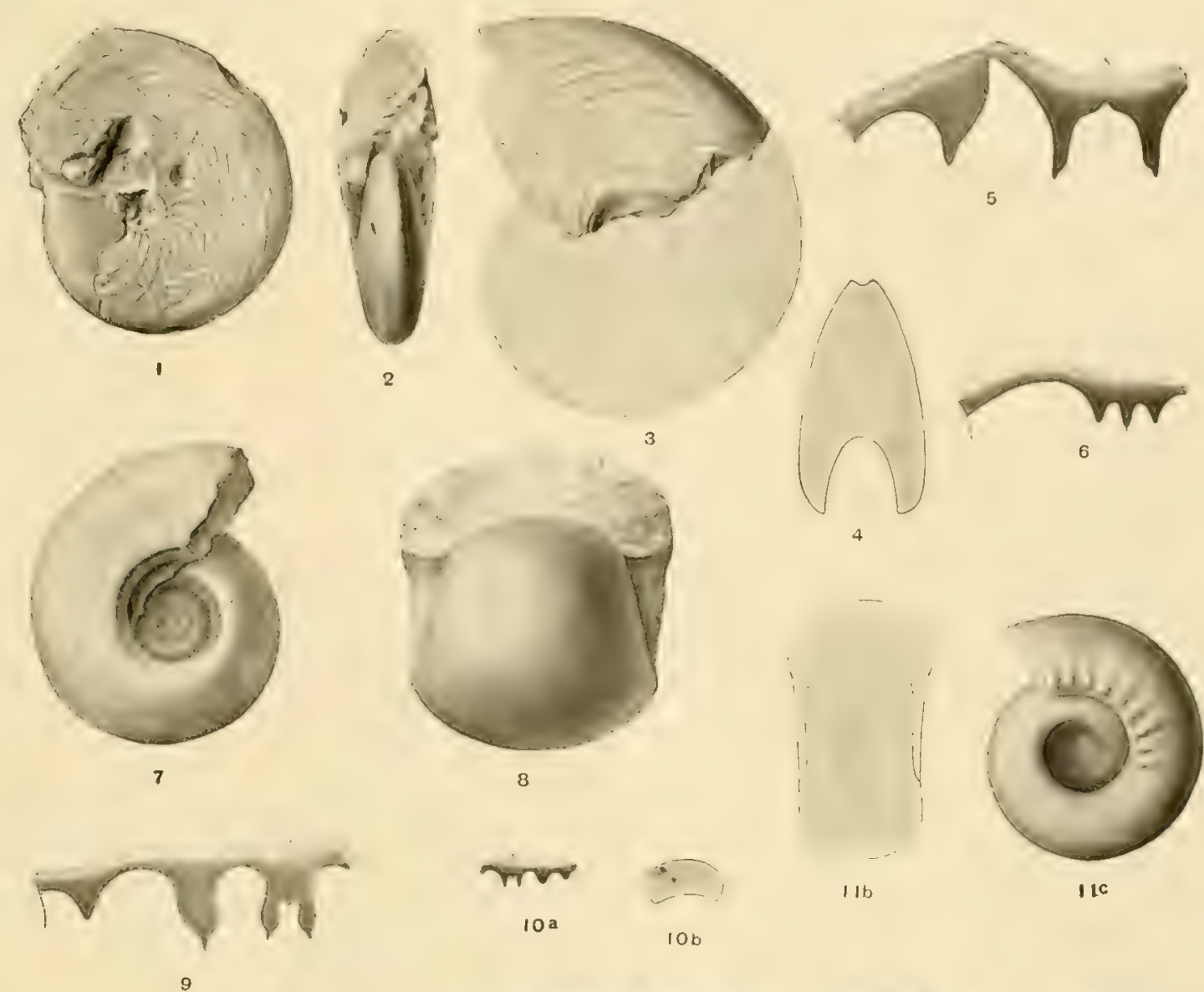

Trminr
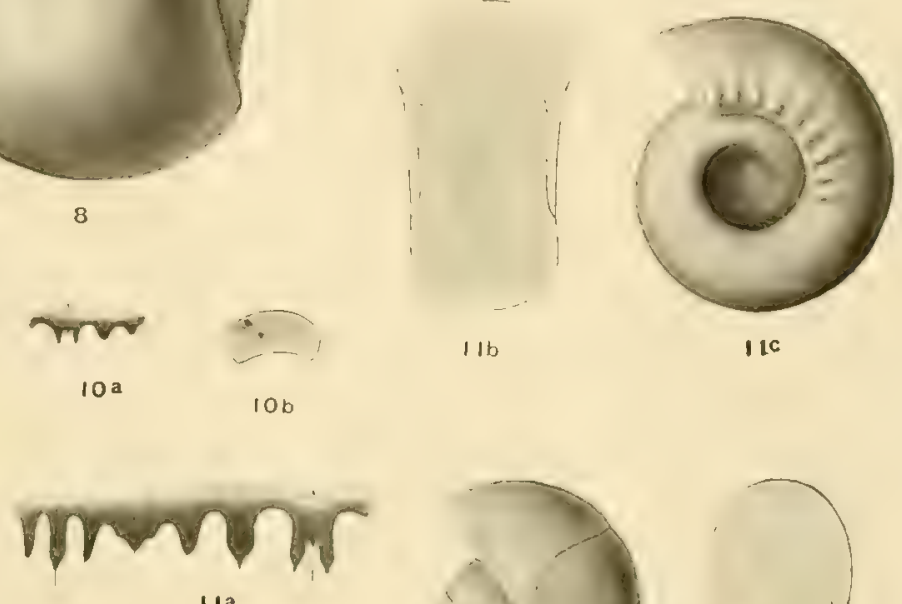

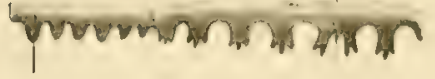
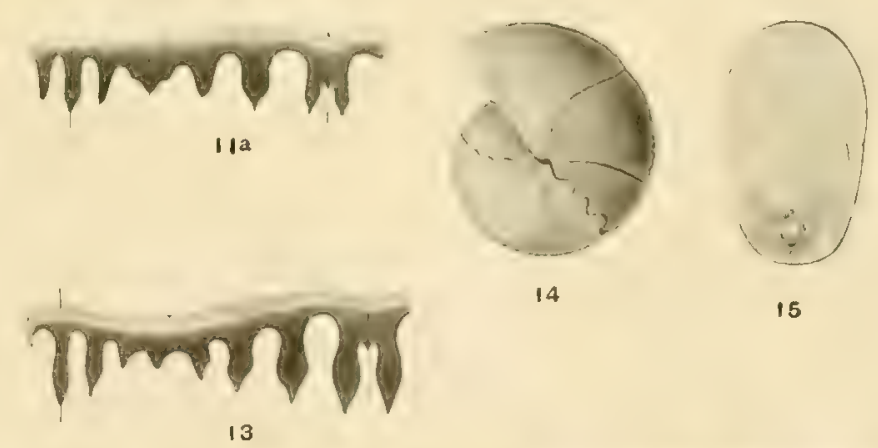

14

15

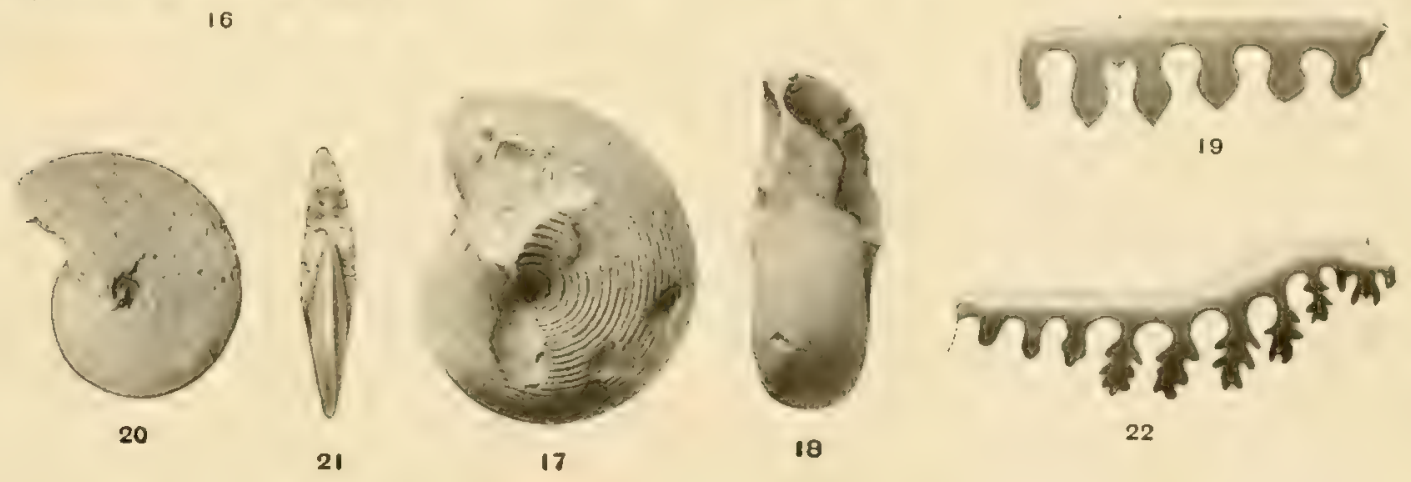



PLATE XXII. 


\section{PTATE, XXII.}

Pinge.

Figs, 1-3. MFDLicotTia copei White

Wichita Permian, military crossing of Big Wichita River, Baylor County, Tex. Specimen in Nat. Mus.

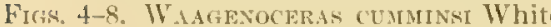

Wichita Permian, locality same as above.

Specimen in Nat. Mus.

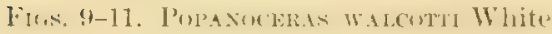

Wichita Permian, Iocality same as above.

Specimen in Nat. Mus.

Note, - This plate was P'I. I, Bull. U. S. (ieol. Survey No. 7T.

$19 \cdot 2$
48 

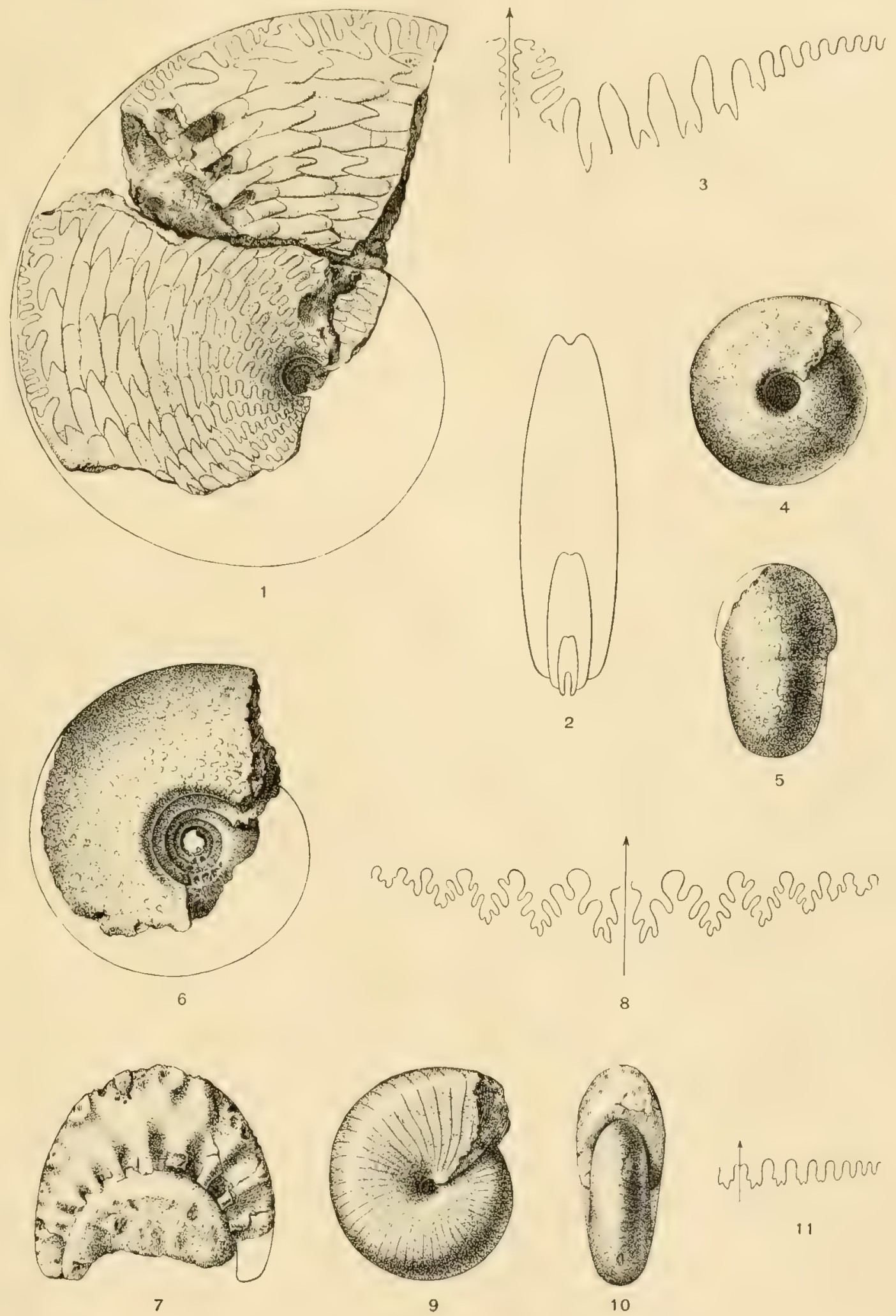

Wh की nonor 



\section{PLATE XXIII.}

HON XIII- (1) $2-13$ 


\section{PLATE XXIII.}

I'itict:

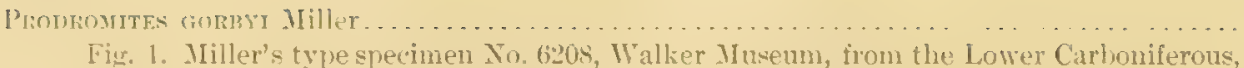

$: 3$ Kinderhook stage, Chouteau limestone, I’in Hook Bridge, Pettis County, Mo.

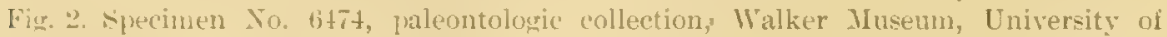
(himaso, from the Lower Carboniferous, Kinderhook stage, Chouteau limestone, Pettis County, Mo.

Sote.-Fig. I was P'. VI, Jnur. Geol., Vol. IX; specimen loaned by the University of Chicago. Fig. 2 is after P'l. VII, Jour. Geol., Vol. IX. 


PLATE IXIV. 


\section{PLATE, XXIV}

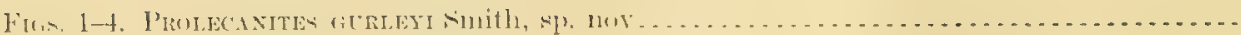

Lower Carboniferous, Kinderhook stage, Cedar (iap, Wright County, Mo.

Figs. 1-3. Side, front, and rear view, enlargerl twice.

Fig. 4. Septa from the same specimen, enlarged 4 times.

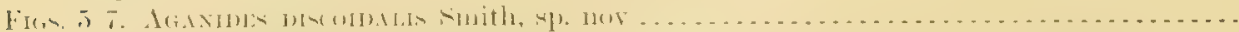

Lower Carboniferous, Kinderhook stage, Chouteau limestone, Pettis County, Mo.

Figs. 5 and 6 . Side and front views.

Fig. 7. Septa of same specimen, enlarged twice.

Figis. 8-12. MIUENSteroceras OSAGense Swallow

Lower Carboniferous, Kinderhook stage, Chouteau limestone, Pettis County, Mo.

Figs. 8-10. Both sides and frout, enlarged twice.

Figs. 11 and 12. Side view of same specimen, with part of the outer whorl removed, to show the septa (fig. 12), enlarged twice, septa enlarged $t$ times.

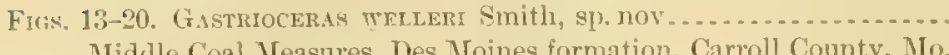

Middle Coal Measures, Des Moines formation, Carroll County, Mo.

Figs. 13-15. Side, front, and rear views of the type specimen, enlarged twice.

Figs. 16-18. Side, front, and rear views of another specimen, showing the septa, enlarged twice.

Figs. 19 and 20. Side and front views of a smaller specimen, eularged twice, to show the surface ornamentation. 

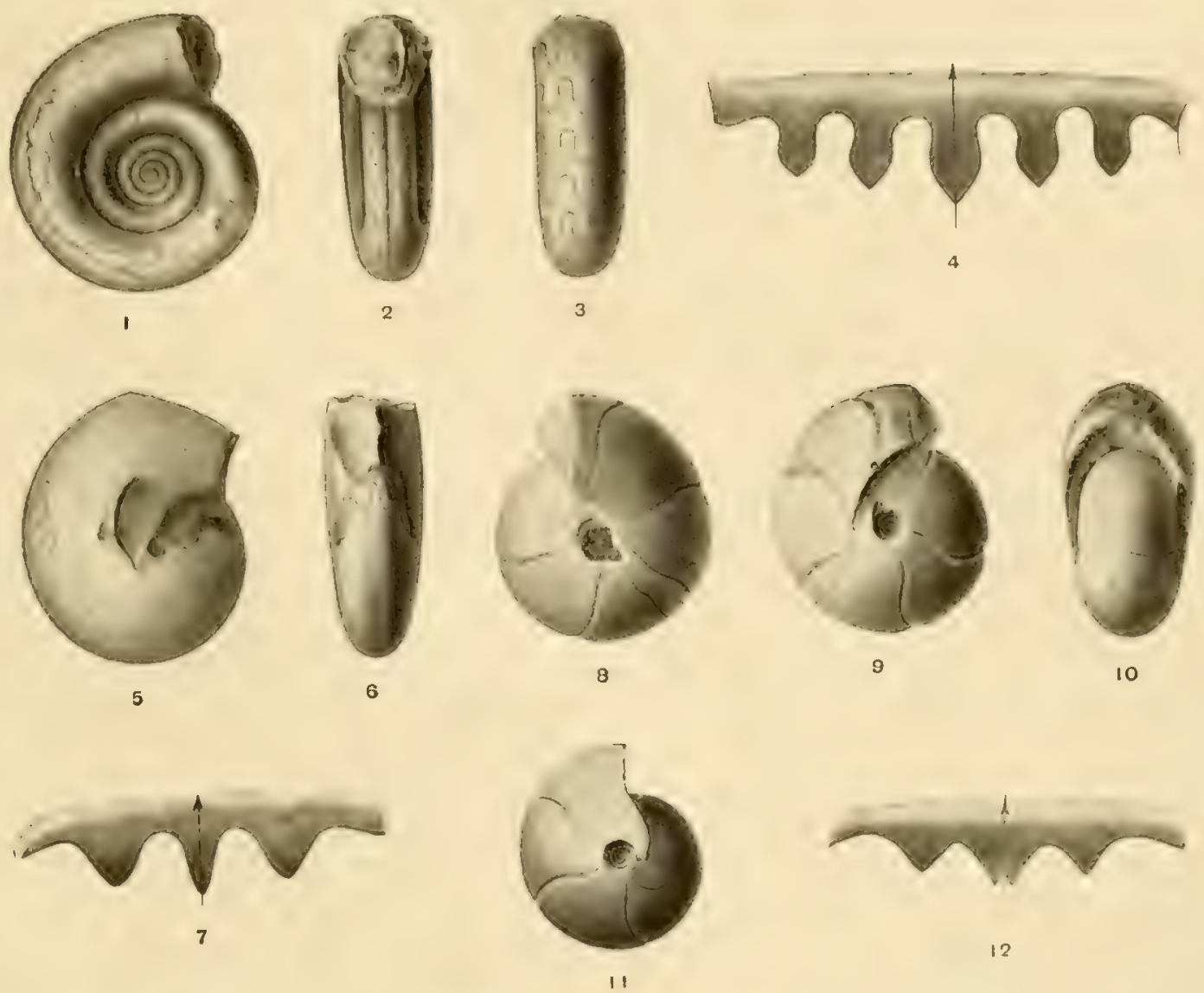

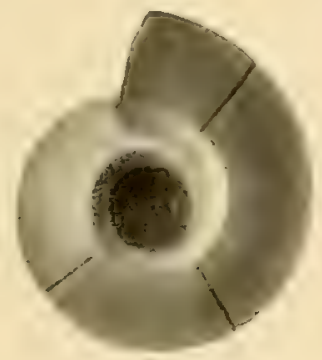

16

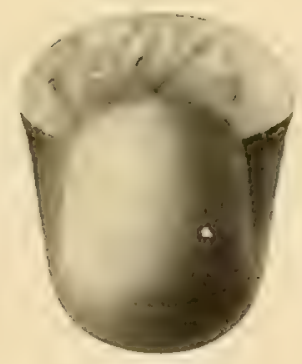

17

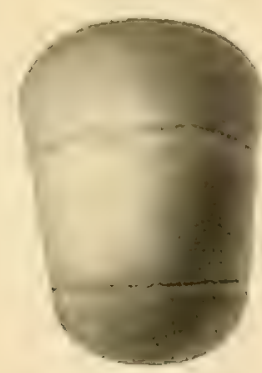

15

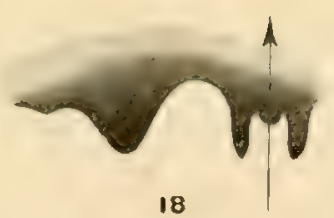

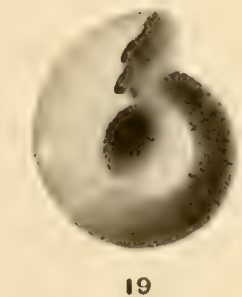

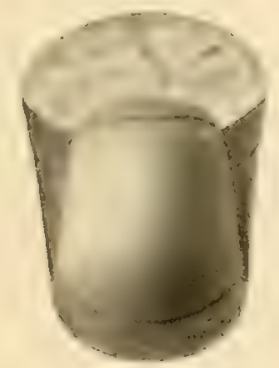

14

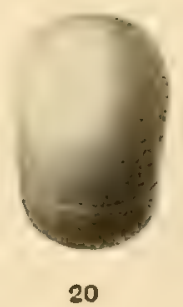



PLATE XXV. 


\section{PLATT: XXT.}

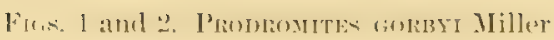

Lower Carboniferons, Kinderhook, Burlington, Iowa. No.6222, paleontologic collection, Walker Musenm, University of Chicago.

Fisis, 3 and 4 . Pronronites pr.matiris smith and Weller

From the Lower Carboniferous, Kinderhook, of Rockford, Ind. No. 6223, paleontologic collection, Walker Museum, University of Chicago.

Fic, 5. Septa of Henexstroma MoJsisovicsi Diener

For comparison with the septa of Prodromites.

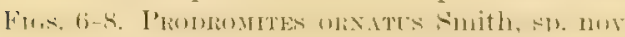

Lower Carboniferous, Kinderhook stage, Choutean limestone, I'ettis County, In.

Figs. 6-7. Side and front views, natural sizes.

Fig. 8. Septa, enlarged 3 times.

(Note-Figs. 1-5, Pl. VIII, Jour. Geol., Vol. IX, No. 3, were loaned by the University of Chicago; fig. 5 is from Pal. Indica, Ser. $\mathrm{XV}$, Cephalopoda of the Lower Trias, PI. XX, fig. lc.) 

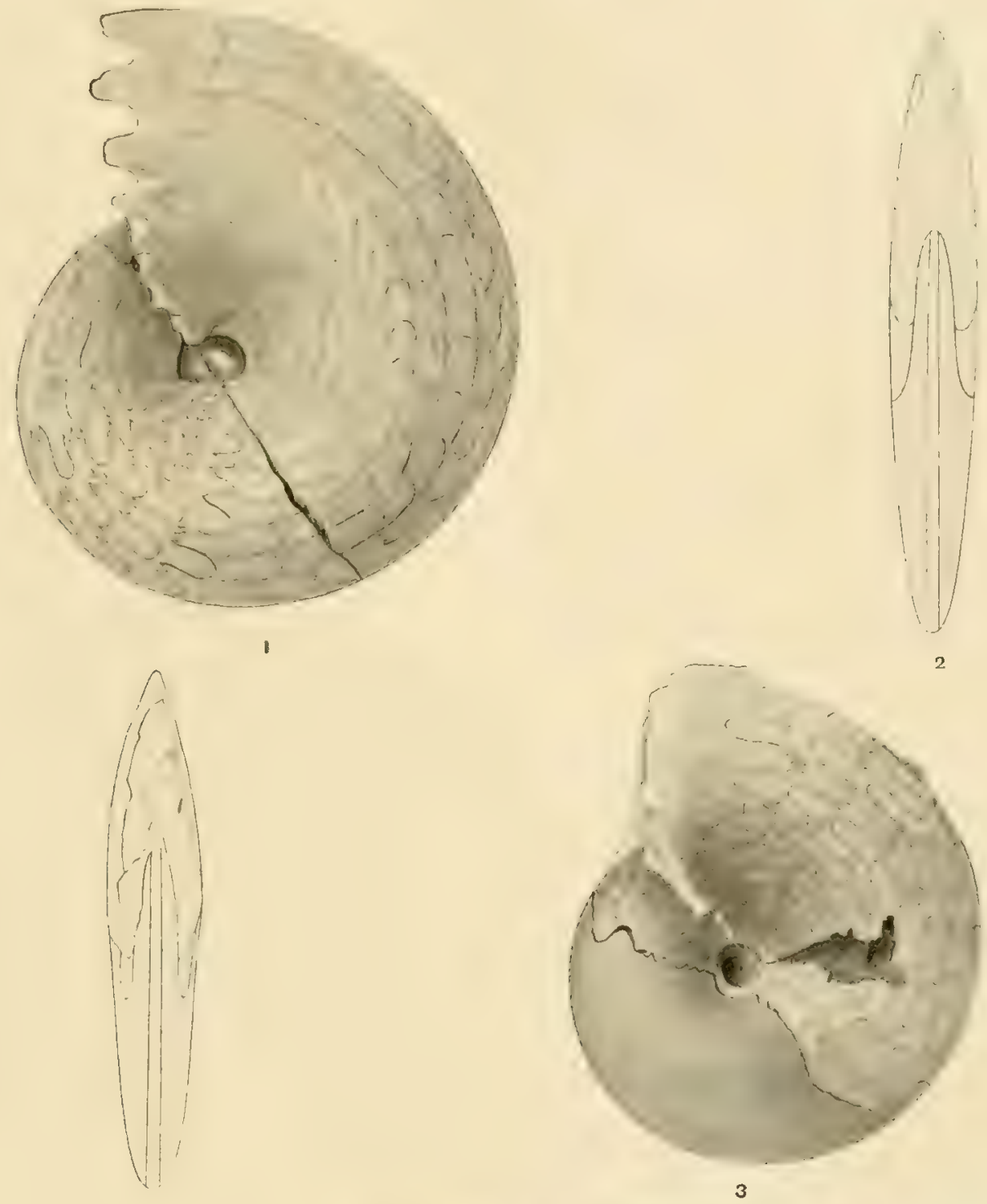

4
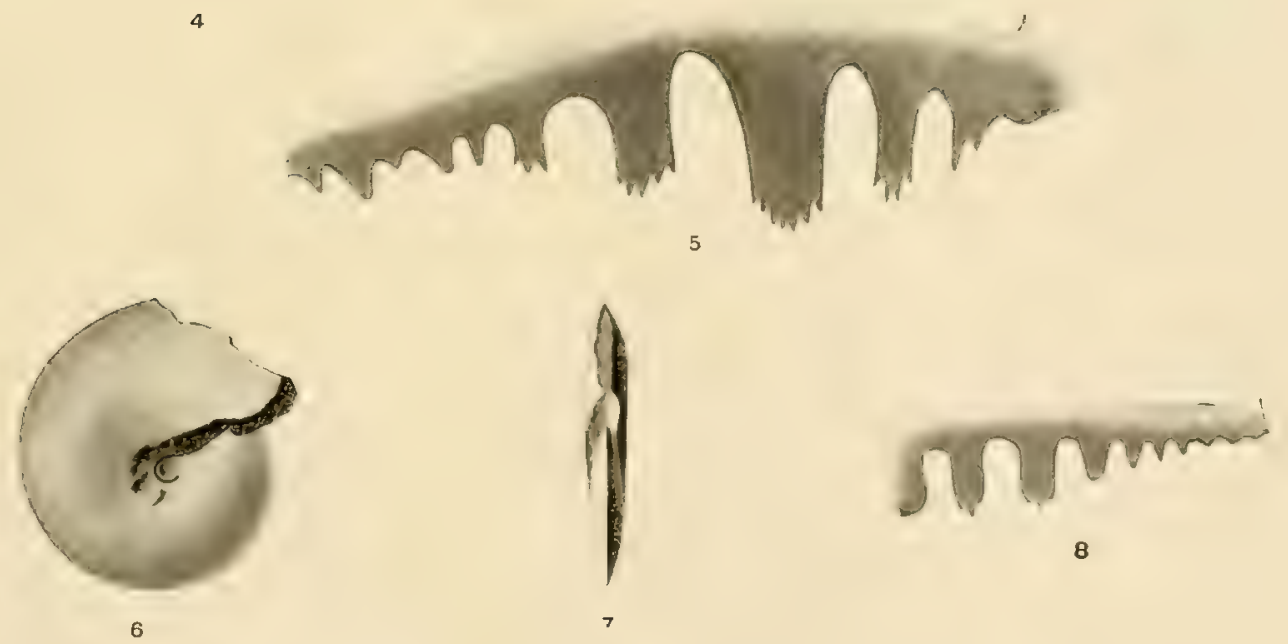


\section{PLATE XXVI.}

Ficis, 1-5. Goxiatites crexistrid Philips. . . . . . . . . . . . . . . . . . . . . . . . . . . . .

Figs. 1,2. Early adult stage, $1 \frac{1}{2}$ times enlarged, Lower Carboniferous, St. Louis-Chester stage, Moorefield, Ark.

Fig. 3. Septa, natural size, Moorefield, Ark.

Fig. 4. Septa, from the Lower Carboniferons limestone of the Iberg, near Cirmud, in the Hartz, 112 times enlarget.

Fig. 5. Surface ornamentation, Lowex Carboniferous, St. Louis-Chester stage, Boles, Ark.

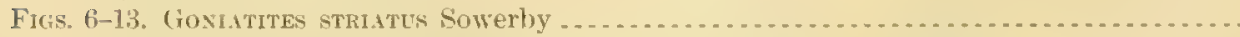

Figs. 6, 7. Lower Carboniferous, St. Louis-Chester stage, Batesville, Ark,, 9.3 mm. diameter, 5 times enlarged.

Fig. 8. Lower Carboniferous, St. Louis-Chester staye, Batesville, Ark., 14 mm. diameter, 112 times enlarged.

Fig. 9. Adult septa enlarged, Batesville, Ark.

Fig. 10. Intemal septa enlarged, Batesville, Ark.

Fig. 11. Septa of young twice enlarged, Batesville, Ark.

Fige. 12, 13. Adult, natural size, Batesville, Ark.

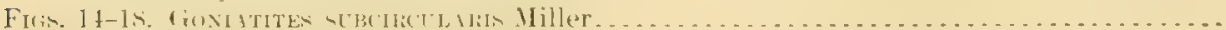

Figs. 14, 15. Three times enlarged, St. Louis-Chester stage, Batesville, Ark.

Figs. 16, 17. Twice enlarged, Batesville, Ark.

Fig. 18. Septa from the above specimen. 


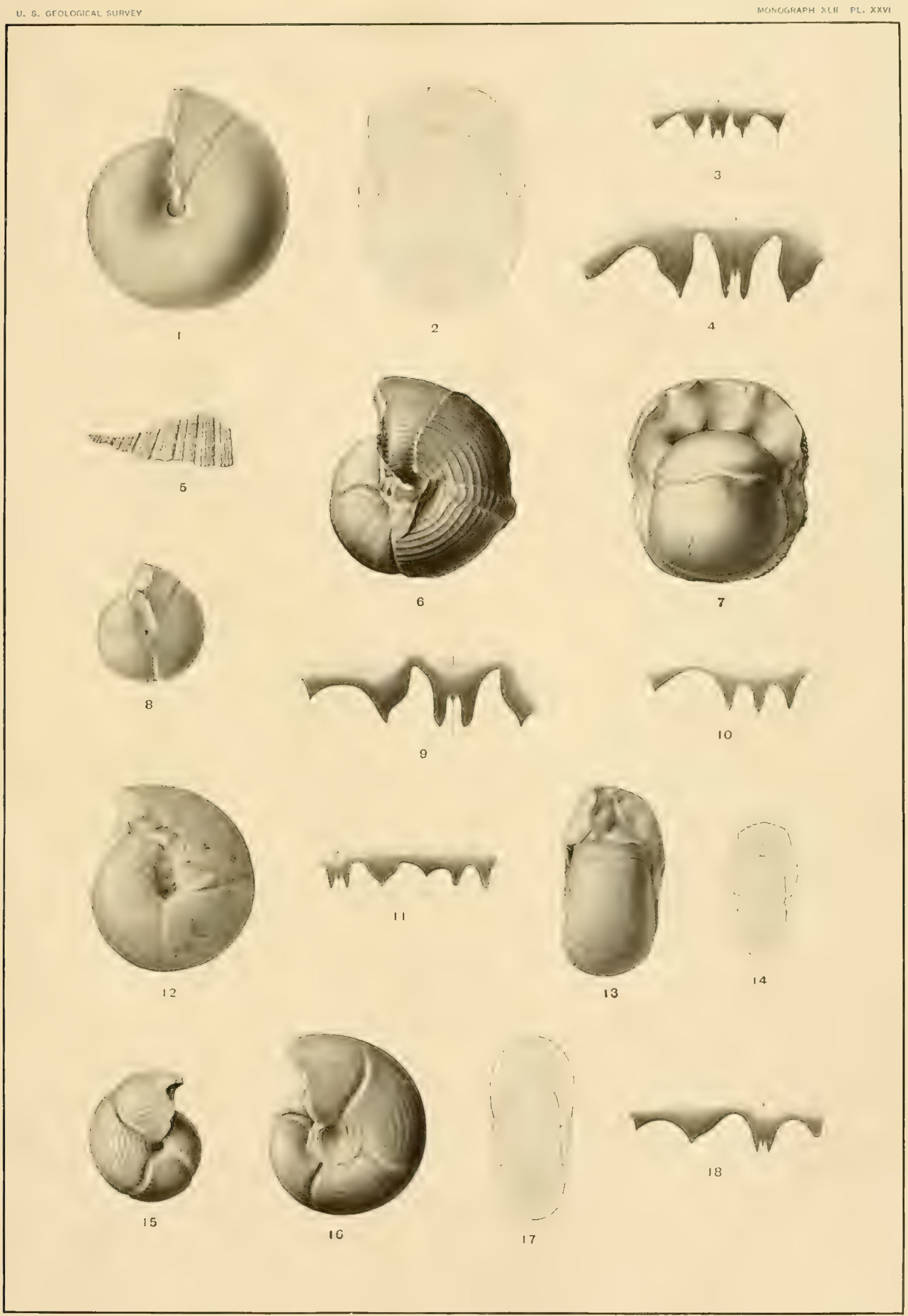

CARBONIFEROUS AMMONOIDS 



\section{PLATE XXVII.}




\section{PLATE XXVII}

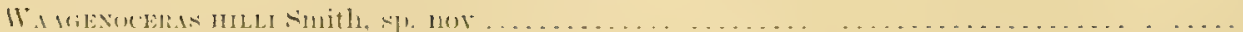

Upper Permian, Double Mountain formation, falls of Salt Croton Creek, Fent County, Tex. (Enlarged $1 \frac{1}{2}$ times.)

Note-From whotograph by Franklin, Palo Alto.

$2(12$ 


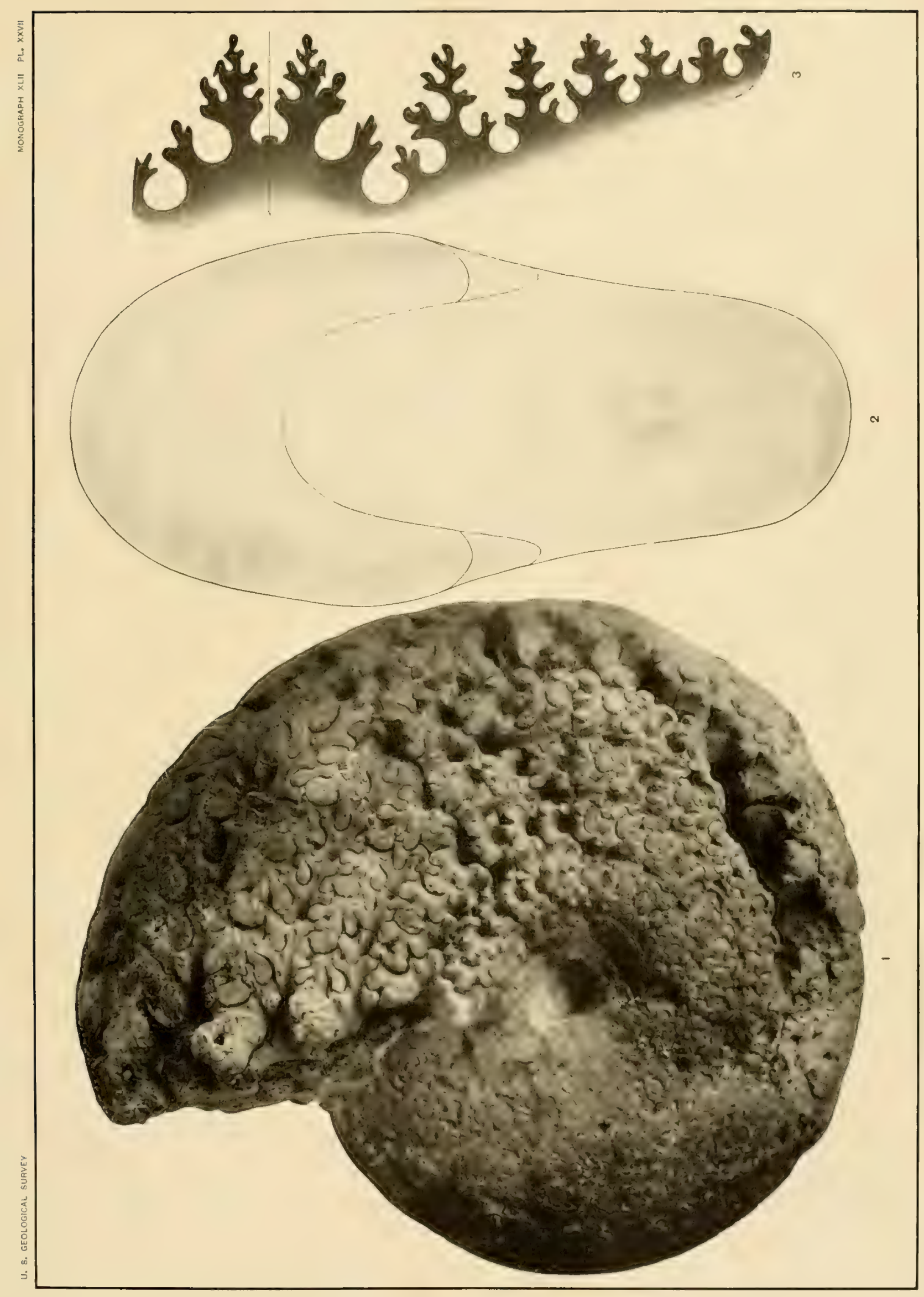

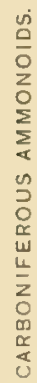



PLATE XXVIII. 


\section{PLATE XXVIII.}

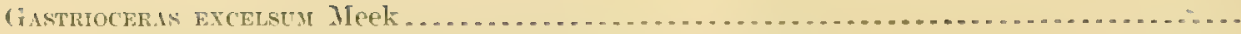

specimen To. 6:26, paleontologic collection, Walker Museum, University of Chicago. Upper Coal Measures, OAage, Kans.

Fig. 1. side riew, natural size.

Fig. 2. Septa, natural size, traced from the specimen.

Note.-Photograph loaneil by Dr. Stuart Weller, Univerwity of Chicago. 


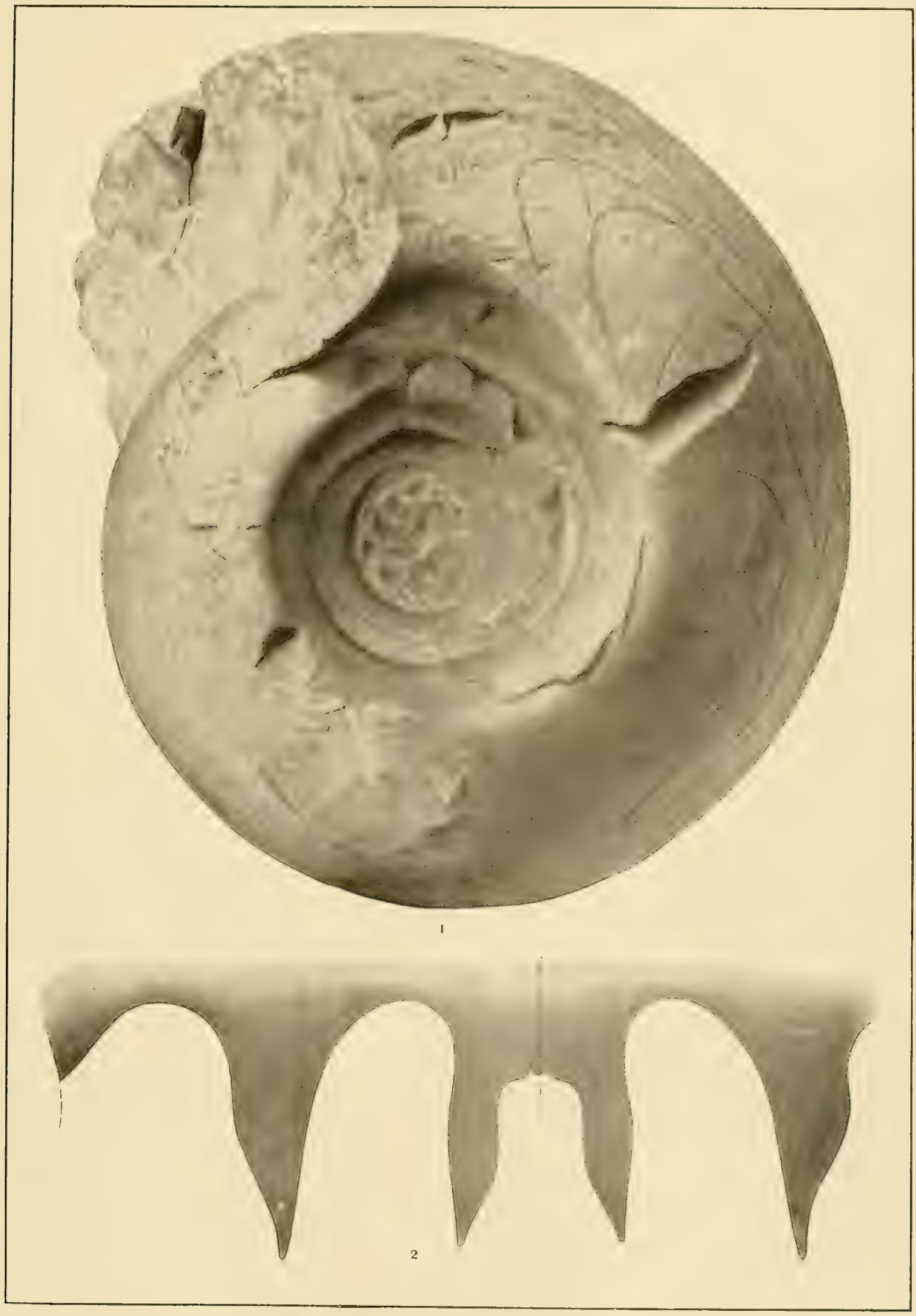





\section{PLATE XXIX.}




\section{PLATE XXIX.}

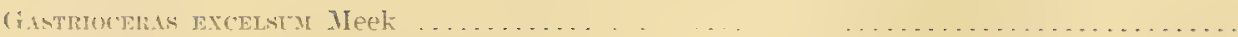

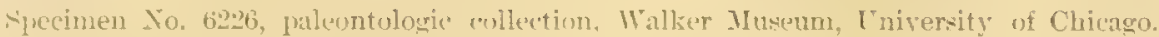
Upper C'oal Measures, (Kage, Kans.

view from alove, natural size.

Nork-Photograph loaner ig Dr. Stuat Weller, Iniversity of chicago. 


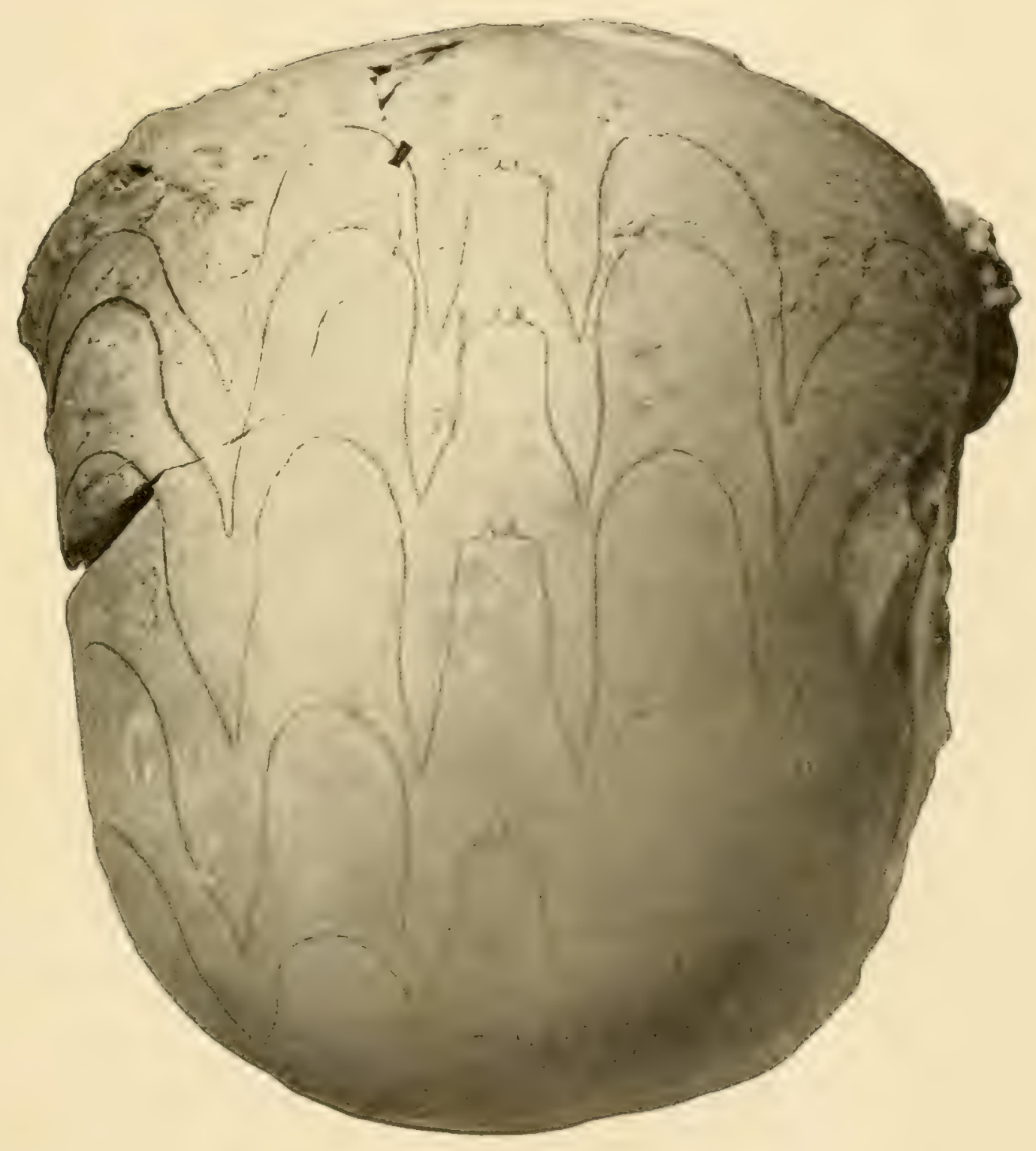





\section{N DEX.}

(Names in italir are synonyms; figures in black-face type are numbers of pages on which detailed descriptions appent: figures in italic denote illustrutions, )

A.

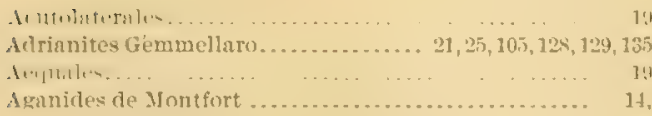

$19,20,21,24,25,27,55,517,57,58,67,7 t i, 11:-117,121$

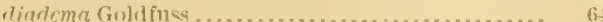

di.coidalis Smith, n. sp .............. 13, 11+115, 145, 196

ixon Hail ................................ 11 .

jexiert Miller and furler............... 13, 115, 14.5, 15.

princeps rle koninck .......................... it

propingulus Winchell ............... 13, 115-116, 115

romingeri Winchell......................... 13,114

Intatorius de lioninck ...................... Ii

$37,112-114,116,121,145,180,186$

? seintoensis Miller and Faber....... 14, 116-117, 145, 16\%

shumarlianms Winchell.................. 13, 117, 11.5

sphavieus Mnrtin............................

var. menistria........................... lis

var. y striatus ............................... so

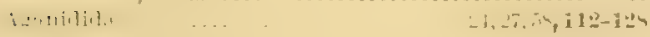

Agrthiceras (iemmellaro .........................

$204,28,105,106,167,104,109,128,130-131$

(risenense smith, si. nov............ 16, 1:1, 138, 146, 19n

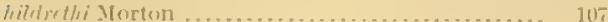

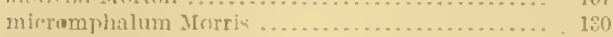

-resi Genmellaro......................... 10, 131

urilicum .................................... 131

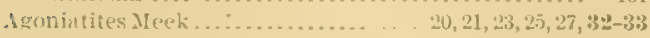

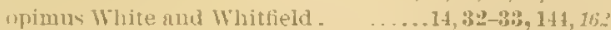

Agonintitidax............... …21,23,27, $32-333,124$

Ammonites ............. . .

hellicosts Morton ... .... . . . . 14: 14ti

revbonntus vun Buch.. . . . . . . . . . is is

collubellus diforton

diredeme Goldfixw

fildethi Mrorton

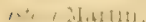

purkern Heilprin . .

mincepar de koninus.

rututurias rle Koninck.

vyluaticus Martin ..

strintus sowerlsy

texien Gichel

Anmonoid genern, table of Paicozoic...

A mumourids, elowitication of Pnleomic......

of dmerican Carbuniferons, genern represented..... 19-3.

Anarcestes Mojnisuries ....... 19,20,21,23, 52,54, $66,57,72,76$

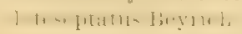

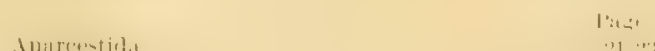

Aphyllites Mojsisovirs.........................

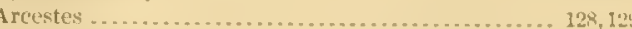

Arcestider ......................... 20, 25, 58,106, 1:9-141

Arthaber, G. von, cited on Permian fauna of Armenia. 21

Bact rites Samblerger.

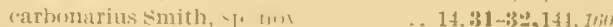

Ractritilie ..... . . 23,27,31-31:

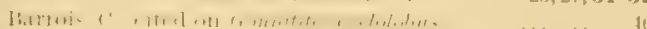

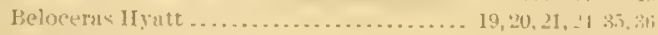

belocerntida ............................ $21,27,34-1$

livemelatiu.

Bend formation, spures foumul in ............... 11

Beneekeinæ ................................

Beyrich, sulndivioms made by ................. 19

Jigsby, J. J., cited ou foniatics princeps............ (i)

Buston group, speeies found in ..................

Branemeras II

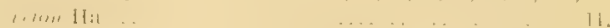

rotatorinut de koninck ................... 112,114

Branner, J. C... acknow ledgments to .............. II

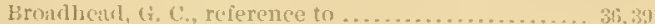

Buch, L. von, reierence ti ....................

$1:$

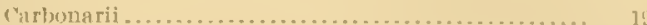

Carboniftrous, ammonoids of American ........... 25, 2s correlation tuble of .... . . . . . . . . . . . . . . . . 17-1s

stratigraphy of American.................... 13-17

Cinnites Mojuisovic's........

celoecergs HIfutt

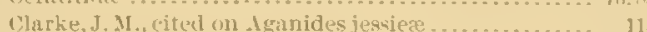

Clear Fork berls, species found in ................

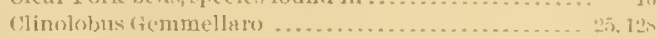

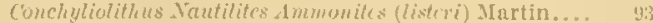

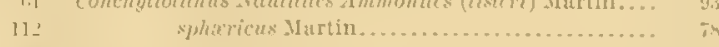

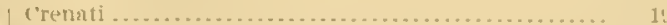

Crick, G. C. Tic Fonorl, A. H., and Crick, G. C.

Cummins, $W$. F. atcknowledgments to ............. I1

Cyclolobidxe.......................25,28, 2:29, 1:\$-141

Cyclolobus Wisgen ................... 20,25, 1229,135

Clymenia Guembel....................... 19, 19.

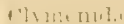

Clyphites Wungen .......................... 
INDFX.

I)

Dirrelices Gemmellaro.

Diener, C., cited on Hedenstroemia mojsisovicui ..... pited on Medlicottia........................... 4i

Dimeroceras Hyatt . ...................... 23, 57,67

Dimorphocere. ................................ 33

Dimorphoceras Hyatt.

$24,26,27,58,76,124,126-127,128$

texanum Smith, sp, nor ...... 16, 126-127, 13s, 146, 18 .

Donrceras Gemmellaro ......................... 25, 12

Double Mountain beds, species found in ............ 16

Dumble, E. T, acknowledgments to ............... 11

\section{F.}

Fayerteville shale, species found in ............... 1

Fonrd, A. H. and Crick, G. C., cited on Schistoceras .. 105

Frech, $F_{-1}$ cited on Glyphioceratidx................ 57

cited on Goniatites divisus ...................

cited on Hronoritinge ......................... 41

(i.

Gant, A. B., acknowledgments to ................. 11 Gastrioceras Hyatt ............ 19, 20,21, 26, 27, 52, 57, 58, 65, $76,82-99,102,103,105,110,111,128,135,137,139$

hranneri smith................ 14,46, $\$ 3 \mathbf{3}-84,145,1$ i earhonarium von Buch ......... 15, \$1-\$6, 91, 96, 145, 176 compressum Hyatt...................... \$6, 145, 166 coronatum Foord and Crick................. s. diunema Goldfuse .............................. bit entogonum Gabb ...................... 11, \$7, 163 excelsim Meek .............. 15, \$4-\$9, 145, 150,204,200 Tlobulosum Yeek and Worthen................ 15, $16,83,89-110,97,95,135,138,145,160,191)$ illinoisense Niller and Gurley .......... 15, $1,145,18 \ldots$ jossa Verneuil . . . .......................... $83,81,90$ Jisteri Martin............ 15, $84,85,86,9:-94,95,145,172$ kansasense Miller and Gurles........ 15,91-92, 145, 15 kingi Hall and Whitfield..............92-9:4,95, 145, 15t marianum II. V.K. . . . . . . . . . . . . ........ $84,93,94$ montgomeryense Miller and Gurley ...... 15,95, 145,150 molinense $\mathrm{Cox}$.................... 15, $15-96,145,15$. oreidentale Miller and Faber ............. 15,96,145, 16 planorbiforme shumard ................ 15,47, 14 russiense Tzwetaev . ......................... 8. $82,10 \%$ subcarum siller and Gur]ey... 15, 16, 97, 135, 13s, 145, 1S: welleri smith, sp. nov ................ 15,95, 115, 19t;

Genmellaro, G. G. cited on Agrathiceras............ 105 cited on Waagenoceras ........................ $13 y$ families recognized by ...................... 20

(ienera, table of Paleozoic ammonoid.............. 23-24 Genufracti................................... 19 Gephyroceras Hyatt....................... 19, 20,21,23 Gephyroceratidæe .................. 20,21,23,24,27,33-34 Glyphioceras Hyatt. $20,24,26,27,57,5 \%, 62-616,76,79,82,8 t, 90,117$ calyx Phillips................ 14, 15, (j2-193, 14, 1s: corbonarium ron Buch ........................ \&5 crenistrin ................................ bis cumminsi Hyatt...................... $70,7 \%, 80,81,101$ diarlema Goldfus ............ 6is-6t, $60,67,90,144,172$ rlubulosum Meek and Worthem ............... by hathawayamum Mcchesney ............. 15, 6t-6j, 144 incisum Hyatt . ......................... 68, 70, 101 leviculum Miller and Faber............ 14,6.3, 141, 164 lixitit Mirtin... micronotum Phillips .......................... 119 mutabile Phillips. . . . . . . .................... 62, 63,66 obtusum Phillips

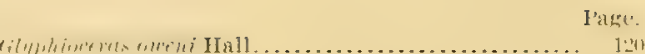

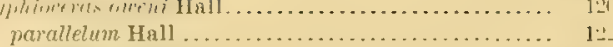

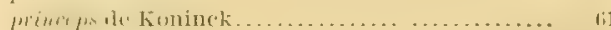
promidum Winchell ...................... 1:i, (i.j)-6it, 1 t

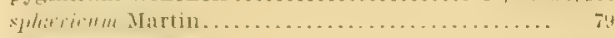

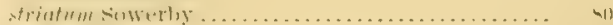
Arithum Phillip .................... (it, tit subcrenntum Frech

Glybumertidit.

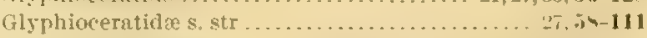

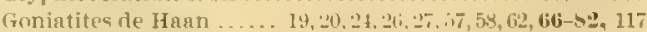
allei Winchell...............................660.123 molrewsi Winchell........................... 5y barlonatus VI, Y.K. K. tito bumlme wis white ....................... lelvalianus de Koninck ..................... 54 hey richianum de Koninck ........................ fis blaivi Miller and Gurley ..................... ti brunnense Miller .............................. 59 culy.x Phillips ............................. 62 corbenurius von Buch .......................... 84, 45 choctawensis Shumard ................... 67-6s, 1 t4 ? colubrellus Morton .................... 15, 141, 14ti compactus Meek and Worthen................. 5 , crenistrin Illillips ............................ 14 . $15,63,66,67,65-\mathbf{i 6}, 79,80,31,144,165,176,175,140,200$ cumminsi. cyclolubre Hhillips........................ 43, ti thiulmun Goldfuss ............................. $62,0.63$ livizus Muenter .......................... nis flkhormmis Miller and (iurley................. 113 entomomus Gabb........................... si

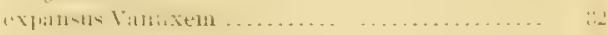
fultomensis Miller and Gurley .................. 10. 10\% gilbertsoni l'hillips .......................... 1:t globulosus Meek and Worthen ............... 88, 59,94

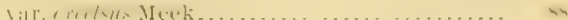

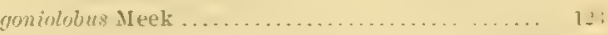

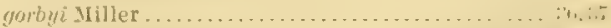

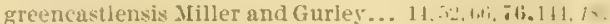
yrecnii Miller ................................ hathrnayoma Mochesner ..................... 64

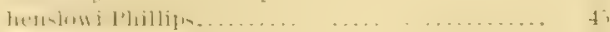

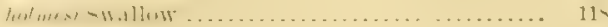
houghtoni Winchell ......................... ...

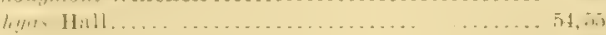
illinoiscusis Miller and (iurley................... 91 indirnensis Miller. ............................ 11m imensis Meek and Worthen.................. 100, 101

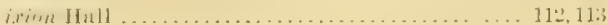

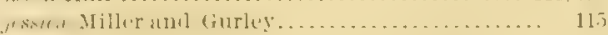
kanstscnx is Miller and Gurley .................. 91 kentuchirnsis Miller.................. 1\$,75.\$1,144,14. kingi Ifall and Whittield ....................

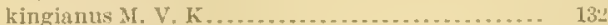
levirnlus Miller and Faber. . . . . . . . . . . . . . . . . 65 limalus Miller and Faber........................ 121 linenris Mnenster. . . . . . . . . ................. 5n listeri Martin ............................6. $6 ., 5, y:$ louisionensis liowley.......................... 54 lunatus Miller and Gurley .......... 15, 7\%-75, 241, 160 Iyoni Meek and Worthen....................... 5t, 5,3 mammillifer Sindberger ....................... 67

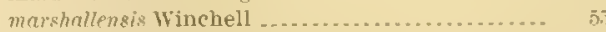
? minimus shumard ..................... 141, 140 missouriensis Miller and Faber ................ 111 mixolobus sandberger ...................... 45,51 munmentis Worthen .................... 3 
INDEX.

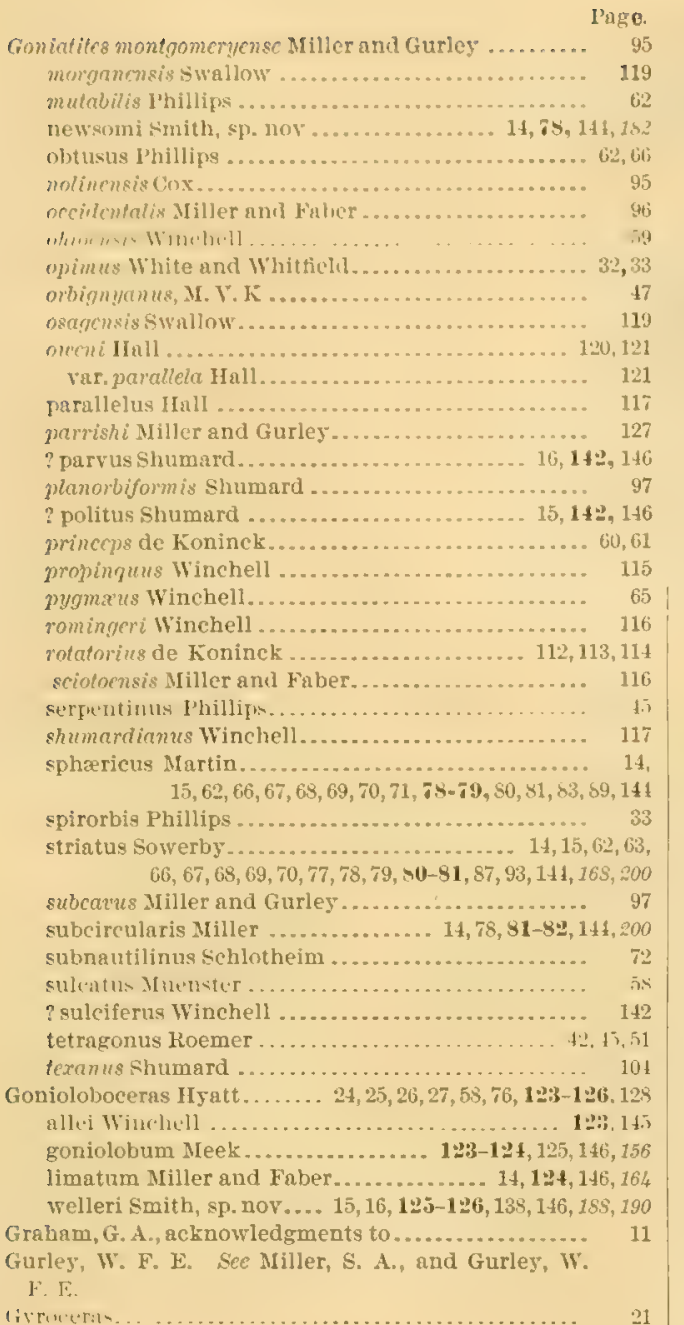

H.

Iran de, citel on Goniatites

Hiluerites, .Injoisuri(n.........................

Haug, E., cited on Gastrioceras carbonarium ........ cited on Glyhioceras.

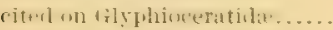

cited on Goniatites.

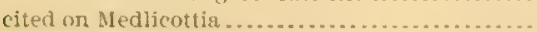

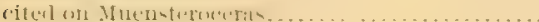

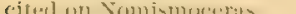

cited on Prolecrnites.

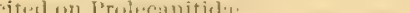

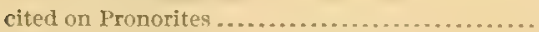

cited on Schistoceras.

cited on Schistecems fultonenge ...........

cited on Schistoceras bildrethi ................

classiticution by ...............................

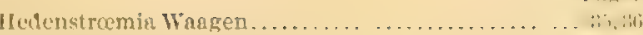
mojsisoricsi biencr. ......

lledenstromint ................. . . . . . .

Holzapfel, b. cited on Ibereiceras .............

cited on thergicerus tetragonus loenser......... $d 2$

riterl on Xomismnerns........................ 31

cited on l'ericyelus kochi .......................... 60

IIomoceras Hyatt................................20, 62 calux Phillips ................................ 69

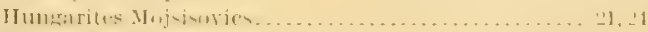

Hungaritidx. ................................ 2

Hyatt, A. acknowledgments to ................... 11

(ited on Annrcestes...........................

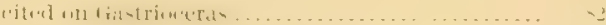

cited on Glyphioceratidre..................... 5 i

cited on Goniatites sphericus ................ 66

citw] on Mnumbluracer,

cited on Muensteroceras 0 weni................. 121

cited on Nomismoceras ........................ 33

cited on Paralegoceras......................... 103

cited on laralegoceras iowense.................. 101

rited on I'ericyclus ............................. 60

cited on Popanoceras ........................... 13:

cited on Prionnceras.......................... $5 \mathrm{~s}$

quoted on Gastrioceras compressum............. 80

quoted on Gastrioceras entogonum.............. s si

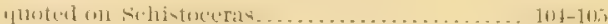

subdirisions made by ............................ 19-20

Hrattoceras Gemmellaro................. 25, 129, 155, 137

I.

Ibergiceras Karpinsky................... 41, 42, 45, 51

tetragonus Roemer ............................41, 42

Ibergiceratidæ.................................. 21, 51

Irregulares . .................................... 19

J.

Jackson, R. T., acknowleulgments to ............... il

K.

Karpinsky, A., eited on fauna of Utral Mountains..... 20 cited on Gastrioceras globulosum . ............. 90 cited on Medlicottia......................... 48, 130 quoted on Pronorites cyclobus var, arkansasensis. 44 cited on Pronorites cyclolobus var. uralensis ...... th cited on schistoceras........................ 10.8 Kinderhook, fossils of ........................ 1:it-1 Koninck, L. G. de, cited on Pronorites crelolobus ....

L.

Lanceolati ....................................... 19

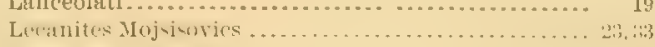
Lecanitidae ....................................

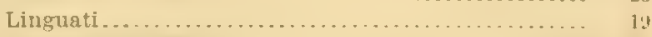

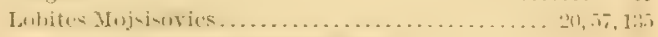
Liwer Coul Mensures, speries fornt in ............ 1;

\section{II.}

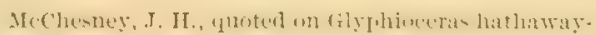

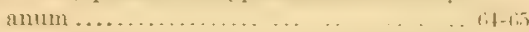
Mæneceras Hyatt....................... 19, 20, 21, 23 Magnosellares ................................... 19 Magnosellaridx.................................. 20, 123 Manticoceras 11 yatt ........................... 20,23

Marshall group, species found in .................... 13 
Neek, F, B., and Worthen, A. H. quoted on Paralegoceras iowense
Page.

Meekoceras

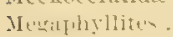

Sedlicotia Waggen. $20,21,24,26,27,41,42,17-49,141$ copei white..................... 16, 18-49,141, 19, Medlicottinæe ................................... 36, 48

Midale Conl Measures, species found in .............. 15

Miller, S. A., cited on prodromites .................... 3

Miller, S. A., and Faber, C., quoted on Aganides sciotoensis. quoted on Gonioloboceras limatum .............. 116-117

Miller, S. A., and Gurley, W. F. E., quoted on Gastrioceras illinnisense quoted on sehistoceras fultonense............... 100

Milleroceras Hyatt ............. 27, 24, 27, 58, 125, 127-120 parrishi viller and Gurley........ 15, 125-123, 116, 150

Mimoceras Hyatt .................. . . . . 19, 21,23

Mojsisovics, E, von, cited on Anarcestes........... 72 cited on Prolecanites........................ 51 subdirisions made by ...... ................. 19

Hinuminlitw.

TIuensteroceras ITyatt - barroisi Holzapfel $20,24,25,27,57,58,76,117-123,124,125,145$ ?holmesi swallow... ? inclianense Miller..

]: 11 $14,11, \overline{1}, 1$;

? morganense Swallow.

$13,119,145$

osagense Swallow $13,14,119,145,196$ oweni Hall.............. 13,37,55, 120-121.122,145, 156 parallelum Ilall .........13,37,55, 121-123, 145, 150, 156 whitei Hyatt... 120,121

\section{N.}

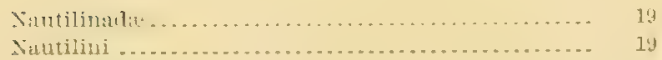

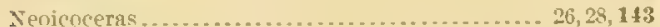
elkhornense Miller and Gurley .......... 15, 143,146, 150 Nomismoceras Hyatt ............. 20,21, 23, 26, 27, 33-31 monroense Worthe1 ..................11,34, 14t, 15s Noritidæ............................ 19, 24, 27, $19-51$

O.

Orbulita sphxricus Martin................... is Osage stage, species of ......................... 11 (utuctrus firiestmeh ........................21,21

P.

Paleozoic ammonoid genera, table of. . ... 23-24 Paleozoic ammonoids, classification of . . $19-25$ ? Paraceltites Gemmellaro .......................... 24 Paralecanites Diener ............................ $\quad 23$ I'arulegocertis Hyat

$24,26,27,57,58,76,82,84,91,49-104,105,106$, $109,110,111,12+, 128,130,131,135,136,137,139$ baylorense White ...............16,89,99-100, 145, 156 illinoiscnsis Miller and Gurley ................... 91 iowense Meek and Worthen ...................... 14,

$15,100-101,102,103,145,156,166$ newsomi Smith, Sp, nop $\ldots-2 .-15,101-10$ t, 145 texanum shumard......................14, 103, 104, 145 tschernyschewi Karpinsky ....................... 103 Parapopanoceras ................................. 128 Paraprolecanites Karpinsky...........21, 24, 33, 42, 45, 51 I'q rapronurites............................41, 42
I'arodoceras II yatt. Page 20,27, 23,56,57,72,76

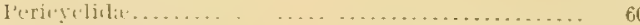
fericyclus Mojsisovics.......................... 14 $19,20,24,25,26,27,57,60-61,67,76,118$ blairi Miller and Gurley. .............. 13, 60-61, 141, 180 kochi Holzapfel ..........................60, 60,190 oweni IIall .................................... 120 ? princeps de Koninck...................... 61, 144

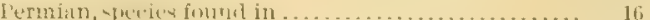
Pharciceras Hyatt. ... . . . . . . . . . . . . . . . . . . . . 20, 21, 24 ? Phenacoceras Frecl............................ 24 Phillips, J., cited on Pronorites cyclolobus ........... 46 Phylloceras.................................... 140 Hinacites Mojsisovics . . . . . . . . . . . . . . . . . . . . . . 19, 20, 21,23 Pinacoceratida. ................................. 20. 20,35, 36 Popanoceras Hyntt - . 20, 21, 25, 20, 2s, 128, 129, 132-134, 135, 14

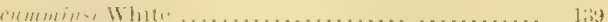
ganti Smith, sp, nov .......... 16, 13:-133, 13s, 146, 190 parkeri Heijprin . .................. 15, 132, 133, 146, 180 walcotti White................. 16, 132, 134,146,192 Popanoceratida..................... 25, 28, 128, 130-134 Primordiales.................................... 19 Primordinlida.................................. 20 Prinnocerns Hyatt. $19,20,21,24,25,27,56,57$, ò-60, $67,73,74,76$ andrewsi Winchell........................ 13,59, 144 helvalianum de Koninck.................... 56, 73 ? brownense Miller ........... . . . . . . . . . 5 $59,144,158$ compactum I I e.ek and Worthen ................. 52 divisum Muenster ............................. 73 ? olioense Winchell................... $59-60,144$ Probeloceras Clarke.......................... 21 I'rucludiscitu's. . . . . . . . . . . . . . . . . . . . . . . . . 135 Prodromites smith and Weller ........ 24, 25, 26, 27, $34-\mathbf{1 1}, 47$ gorbyi Miller, $13,14,34,36,37-39,40,41,55,121,144,194,19.5$ ornatus smith, sp. nov............... 13,39-\$0, 14t, 198 prematurus smith and Weller ................. 13,

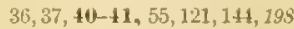

I'rinin:In-

cestriensis Meek.

21 mleck............................... is

Prolecanites Mojsisovica . . . . . . . ................. 14, $19,20,21,24,25,26,27,34,42,45,51-56$ ? compactus Jeek and Worthen . ....... 15, jᄈ, 14t, 158

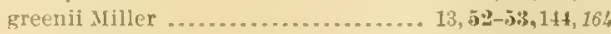
gurleyi Smith, sp. nov ................. 13,53, 141, 196 henslowi Sowerby ......................... 5 houghtoni Winchell ................ 13, is;-ist,14t ?louisianensis Rowley .................... 13, 54,141 lyoni Meek and Worthen..................... 13, $37,52,53,54-55,56,144,160,150,186$ marshallensis winchell................. 13, 50-50 15,144 serpentinus Phillips ..................... 42 I'rule'tunitula ................................... 51

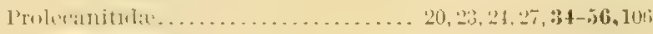
Prolectuitith s. str . . . . . . . . . . . . . . . . \$1-56 Prolobites Karpinsky............................ 21, 23 Promedlicottia ............................. 42 Pronannites Haug................................... 21, 24 Pronorites Mojsisovics ..... 19,20,21, 24, 26, 27, 11-47, $45,50,51$ barroisi Karpinsky............................. to to cyclolobus Phillips .............41, $43,46,51,54,172,174$ var. arkankasensis Smilh ...... 14, 13-17,34,141,172 var, uralensis Karpinsky .............. $43,45,46,47$ mixolobus Phillips .......................... 56 prepermicus Karpinsky .... . ................. $17: 2$ siebenthali......................15, $\mathbf{4}, 144,170$ Pronoritidæ. ........................... 24, 27, 11-19 Propinacoceras Gemmellaro....................21, 24, 11 


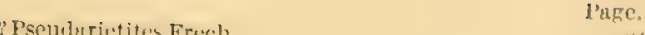

Pseudonomismoceras Frech.......................

Plychites cumminei White .............................

Ptychitidx...................................... 5s

li.

Rockford, Ind., species found at ................... 13

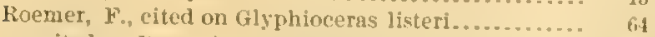

cited on Pronorites cyclolobus ................... 46

\section{$s$.}

Siggeceras Majuiverice. 20

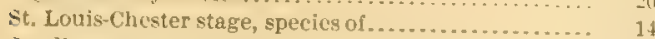

Sandberger, G. and F., subdivisions made by .......... 19

Sandbergeroceras Hyatt.................... 19, 20, 21, 24

strrati .....................................

Schistoceras IIyatt ................... 20,24,26,27,58,76,

$10 \leftarrow-111,128,129,130,131,135,136,137,139$ fultonense Miller and Gurles .... 15, 105, 106-105, 145, 130 hildrethi Morton .............................. 15,

$16,102,105,107-108,109,111,139,145,154$ hyatti Smith, sp. now ........................ $104,106,107,108-111,145,158,190$ missouriense Miller and Faber... 16, 103, 107, 111,145.164 Schucbert, Charles, acknowledgments to ........... 11 Scbuchertites Smith, gen, nov ............ 24, 26, 27, 49-50 grahami Smith, sp. nov ............ 16, 50 (0-51, 138, 144, 190

Shumard, B. F., quoted on Goniatites chocti wensis .. 67-6,5 quoted on Paralegoceras texanum ............. 104 Shumardites Smith .......... 25, 26, 28, 128, 129, 18t-139, 139 simondsi Smith, sp. nov ........ 16, 131, 13i-139, 146, 154 sicanites Gemmellaro ........................ 24, 11,42 Simonds, F. W., reknowledgments to ............... Simplices ....................................... 19 Spirula ..........................................

Sporadoceras HIytt.................. 19, 20,21, 23,57,67 mammilliferum Sandberger.................... 67 subinvolutum Muenster ........................... 67 Stacheoceras Gemmellaro ................... 21, 25, 128, 135 Steinmann. G., classification by . . 21
Suess, E., cited on Ammonites in Meritermonen l'age. region..................................

$\mathrm{T}$.

Thalassocerus Gemmellaro ...................... 21,25 Timanites Mojsisovies ................................ 21, 21,23 Tornoceras Hyatt................. 19, 20, 21, 23, 56, 57,58,115 retrorsum von Buch........................

Trixnoceras II yatt............................. $20,21,24$

Trutitua...................

Tropitidx.............................. $20,58,70,83$

Tzwetaev, M., cited on Brancoceras rotatorium...... 114

U.

Upper Coal Mersures, snecics found in $15-16$

w.

Wargen, W., cited on Hedenstromia genera recognized by.

20

agenocerns Gemmellaro .......................... 20 ,

cumminsi white stachei 6 , nov ................ 16, 140-141,146, 202

Fiv

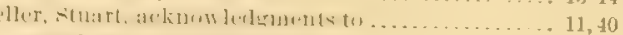

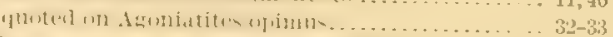

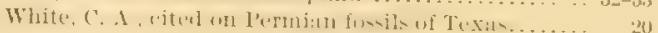
quoted on Paralegoceras baylorense............. quoted on Popanoceras Walcotti ................... 134

Wichita beds, species found in ......................

Worthen, A. II. See Meek, F. B., and Worthen, A. H

$\mathrm{X}$

Xenaspis Wragen .............................. ${ }_{23}$

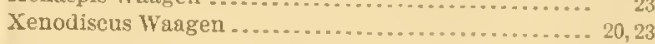

Z.

Zittel, K. A. von, cited on Gastrioceras.............. $\$ 82$ cited on Prionoceras..................................... 


\section{.}




\title{
PUBLICATIONS OF UNITED STATES GEOLOGICAI SURVEY.
}

\author{
[Monograph CLII.]
}

The serial publications of the United States Geological Surver consist of (1) Annual Reports, (2) Monographs, (3) Professional Paper's, (4) Bulletins, (5) Mineral Resources, (6) Water-Supply and Irrigation Papers, (7) Topngraplic Atlas of the

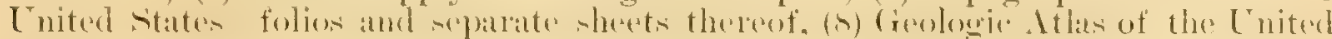
States-folios thereof. The classes numbered 2, 7, and 8 are sold at cost of publication; the others are distributed free. A circular giving complete lists ma be had on application.

\section{MONOGRAPHS.}

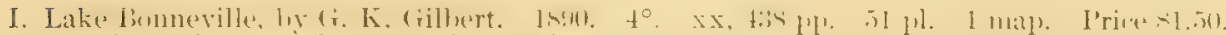

II. Tertiary History of the Grand Cañon district, with atlas, by C. E. Dutton, Capt., U. S. A. $1852 . \quad t^{\circ}$. xir, $26 \pm$ pp. $\quad+2$ pl. and atlas of $2 \pm$ sheets folio. Price sio.

III. Geology of the Comstock lode and the Wrashoe district, with atlas, by G. F. Becker. 1882. $4^{\circ}$. $\mathrm{xv}, 422 \mathrm{pp} .7 \mathrm{pl}$, and atlas of 21 sheets folio. Price $\$ 11$.

IV. Comstock mining and miners, by Eliot Lord. 1883. $4^{\circ}$. xiv, $451 \mathrm{pp} .3 \mathrm{pl}$. Price $\$ 1.50$.

T. The copper-bearing rocks of Lake Superior, by R. D. Irving. 1883. 40. xvi, 464 pp. $151.29 \mathrm{pl}$, and maps. Price $\$ 1.85$.

VI. Contributions to the knowledge of the older Mesozoic flora of Virginia, by IV. W. Fontaine. 1883. $4^{\circ}$. xi, $144 \mathrm{pp}, 5+1.54 \mathrm{pl}$. Price 81.05 .

VII. Silver-lead deposits of Eureka, Nevada, by J. S. Curtis. 18S4. $4^{\circ}$. xii, $200 \mathrm{pp.} 16 \mathrm{pl}$. Price 81.20 .

VIII. Paleontology of the Eureka district, by C. D. Walcott. 185t. $t^{\circ}$. xiii, 298 pp. $2 t 1.2 t$ pl. Price 81.10.

IX. Brachiopoda and lamellibranchiata of the Raritan clays and greensand marls of New Jersey, by R. P. Whitfield. 1885. $4^{\circ}$. $\mathbf{x x}, 338 \mathrm{pp} .35 \mathrm{pl}$. 1 map. I'rice $\$ 1.15$.

I. Dinocerata. A monograph of an extinet order of gigantic mammals, by O. C. Marsh. 1886. $4^{\circ}$. xviii, 243 pp. 56 l. $56 \mathrm{pl}$. Price $\$ 2.70$.

XI. Geological history of Lake Lahontan, a quaternary lake of northwesteri Nevada, by I. C. Russell. 1855. $4^{\circ}$. xiv, 288 pp. 46 pl. and maps. Price \$1.75.

XII. Geology and mining industry of Leadrille, Colorado, with atlas, by S. F. Emmons. $1886 . \quad 4^{\circ}$. xxix, $770 \mathrm{pp} .45 \mathrm{pl}$. and atlas of 35 sheets folio. Price $\$ 8.40$.

XIII. Geology of the quicksilver deposits of the Pacific slope, with atlas, by G. F. Becker. 18s8. $4^{\circ}$. xix, $486 \mathrm{pp}$. $7 \mathrm{pl}$. and atlas of 14 sheets folio. Price $\$ 2$.

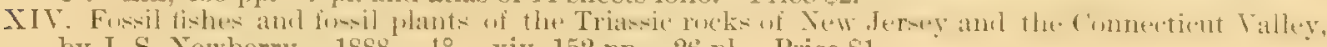
by J. S. Newberry. 1888. $4^{\circ}$. xiv, $152 \mathrm{pp} .26 \mathrm{pl}$. Price $\$ 1$.

XV. The Potomac or younger Mesozoic Hora, by W. II. Fontaine. 18s9. $4^{\circ}$. xiv, $377 \mathrm{pp.} 180 \mathrm{pl}$ Text and plates bound separately. Price \$2.50.

XVI. The Paleozoic tishes of North America, by J. S. Newberry. 18s0. $4^{\circ} .340 \mathrm{pp} .53 \mathrm{pl}$. Price 81.00.

XVII. The flora of the Dakota group, a posthumous work, by Leo Lesquereux. Edited by F. H. Knowlton. 1891. $4^{\circ} .400 \mathrm{pp}$. 66 pl. Price $\$ 1.10$.

IVIII. Gasteropoda and Cephalopoda of the Raritan clays and greensand marls of New Jersey, by R. P. Whittield. 1891. 40. $402 \mathrm{pp} .50 \mathrm{pl}$. Price $\$ 1$.

XIX. The Penokee iron-bearing series of northern Wisconsin and Jichigan, R. D. Irving and C. I: Van Hise. 1892. $4^{\circ}$. xix, $534 \mathrm{pp}$. Price $\$ 1.70$.

XX. Geology of the Eureka district, Nevada, with an atlas, by Arnold Hague. 1892. 40. xii, 418 pp. 8 pl. I'rice 55.25.

XXI. The Tertiary rhymchophorons Coleoptera of the United States, by S. HI. Scudder. $1893.4^{\circ}$. xi, 206 pp. 12 pl. Price 90 cents.

XXII. A manuel of tongraphic methods, by Henry Gannett, chief topographer. 1893. $4^{\circ}$. xiv, 300 pp. $18 \mathrm{pl}$. Price $\$ 1$.

XXIII. Geology of the Green Mountains in Massachusetts, by Raphael Pumpelly, T. N. Dale, and J. E. Wolff. 189t. 40. xiv, $206 \mathrm{pp}$. $23 \mathrm{pl}$. Price $\$ 1.30$. 
XIIV. Mollusca and Crustacea of the Miocene formations of New Jersey, by R. P. Whitfield. 1594. $4^{\circ} .193 \mathrm{pp} .24 \mathrm{pl}$. Price 90 cents.

XIY. The Glacial Lake Agassiz, by Warren Upham, 1895. $4^{\circ}$. xxiv, $658 \mathrm{pp} .38 \mathrm{pl}$. Price $\$ 1.70$. XXVI. Flora of the Amboy clays, by J. S. Newberry; a posthumous work, edited by Arthur Hollick. 1895. $t^{\circ} .260 \mathrm{pl} .58 \mathrm{pl}$. Price $\$ 1$.

XXiII. Geology of the Denver Basin in Colorado, by S. F. Emmons, Whitman Cross, and G. H. Eldridge. $1896.44^{\circ} .556 \mathrm{pp} .31 \mathrm{pl}$. Price 51.50.

XXVIIL. The Marquette iron-bearing district of Michigan, with atlas, by C. R. Tan Hice and $W . S$. Bayley, including a chapter on the Republic trough, by H. L. Smyth. $1895 . \quad 4^{\circ} .608$ pp. 35 pl. and atlas of 39 sheets folio. I'rice $\$ 5.75$.

IXIX. Geology of old Hampshire County, Massachusetts, comprising Franklin, Hampshire, and Hampden counties, by B. K. Emerson. 1898. 4․ xxi, $790 \mathrm{pp.} 35 \mathrm{pl}$. I'rice $\$ 1.90$.

XXX. Fossil Meduse, by C. D. Walcott. 1898. 40. ix, 201 pp. 47 pl. Price \$1.50.

XXXI. Geology of the Aspen mining district, Colorado, with atlas, by J. E. Spurr. 1898. $4^{\circ}$. $x \times x v$, $260 \mathrm{pp} .43 \mathrm{pl}$. and atlas of 30 sheets folio. I'rice 83.60

XXXII. Geology of the Yellowstone National Park, Part II, descriptive 'geology, petrography, and paleontology, ly Arnold Hague, J. P. Iddings, W. H. Weed, C. D. Walcott, G. H. Girty, T. W. Stanton, and F. H. Knowlton. 1899. 4\% xvil, 893 pr. 121 pl. Price 5.2.45.

IXXII. Geology of the Narragar sett Basin, by N. S. Shaler, J. B. Woodworth, and A. F. Foerste. 1899. $4^{\circ} . \mathrm{xx}, 402 \mathrm{pl}$. $31 \mathrm{pl}$. Price 81.

XXXIV. The glacial gravels of Maine and their associated deposits, by G. H. Stone. $1899 . \quad 4^{\circ}$. xii, 499 pp. 52 j. Price $\$ 1.30$.

XXYV. The later extinct floras of North America, ly J. S. Newberry; editerl by Arthur Hollick. 1898. $4^{\circ}$. xviii, $\left.295 \mathrm{~m}\right) 68 \mathrm{pl}$. Price 81.25.

XXXYI. The Crystal Falls iron-bearing district of Michigan, by J. M. Clements and H. L. Smyth; with a chapter on the Sturgeon River tongue, by IV. S. Bayley, and an introduction hy C. R. Van Hise. 1899. $4^{\circ}$. xxxvi, 512 1p. 53 j,. Price 52.

XIXVII. Fossil flora of the Lower (Cal Measures of Missouri, by David White. 1899. $4^{\circ} . \quad x i, 467$ pp. 73 pl. P'rice $\$ 1.25$.

XXXVIII. The Illinois glarial lobe, by Frank Leverett. 1899. $4^{\circ} . \quad \mathrm{xxi}, 81 \overline{7}$ pl. 24 pl. Price 81.60.

XXXIX. The Eocene and Lower Oligocene coral faunas of the United states, with descrintions of a few doubtiully Cretaceous species, by T. W. Taughan. 1900. to. $263 \mathrm{lp}$. 24 pl. Price $\$ 1.10$.

XI. Adephagons and clavicom Coleoptera from the Tertiary deposits at Florissant, Colorado, with descriptions of a few other forms and a systematic list of the non-rhyncophorous 1 ertiary Coleoptera of North America, by S. H. Scudder. 1900. t. $^{\circ} 14 \mathrm{sp}$. 11 pls. Price so cents.

XLI. Glacial formations and drainage features of the Erie and Ohio basing, by Frank Leverett. 1902. $4^{\circ} .802 \mathrm{pI} .26 \mathrm{pls}$. I'rice $\$ 1.75$.

XLII. Carboniferous ammonoids of America, by J. I'. Smith. 1903. 40. 211 p. 29 pls. Price 85 cents.

In press:

XLIII. The Mesabi iron-bearing district of Minnesota, by C. K. Leith.

XLIY. I'seudoceratites of the Cretaceons, hy Alpheus Ilyatt, edited by T. IV. Stanton.

XLV. The Vermilion iron-bearing district of Minnesota, by J. II. Clements.

All remittances must be by MoNEY ORDER, made parable to the Director of the United States Geological Surrey, or in CuRRENCr - the exact amount. Checks, drafts, and postage stamps can not be accepted. Correspondence should be addressed to

The Director.

United States Geological Survey. W ASHiNGTON, D. C. 
[Take this leaf out and maste the separater titles upon three of your catalogue carls. The first and second titles need no addition: over the third write that subject under which you would place the bonk in your library.]

\section{LIBRAIY CATALOGUE SIJIS.}

United States. Inymement of the interior. ( $L^{\top}$.S. geologicul survey.) Department of the interior | - | Monographs | of the | United States geological surrey | Volume ILII | [Seal of the department] |

Washington | government printing oflice | 1903

Sicond title: United States geological survey | Charles D. Walcott, director | - The | Carboniferous ammonoids of America | by | James Perrin Smith | [Vignette] |

Washington | government printing office | 1903

1. $211 \mathrm{pp}, 29$ pls.

Smith (James Perrin).

United States geological survey | Charles D. Walcott, director $|-|$ The | Carboniferous ammonoids of America | by | James Perrin Smith | [Vignette] |

Washington | government printing office | 1903

4․ $211 \mathrm{pp}, 29 \mathrm{pls}$.

[UNITED STATES. Department of the interior. (U. So geolagical survey.) Monograph XLII.]

United States geological survey | Charles D. Walcott, di rector $|-|$ The | Carboniferous ammonoids of America | by | James Perrin Smith | [Vignette] |

Washington | government printing oftice | 1903

40. $211 \mathrm{pp}, 29 \mathrm{pls}$.

[UNITED STaTES, Dcportment of the interior. (U. S. geological survey.) Monograph XIII.] 





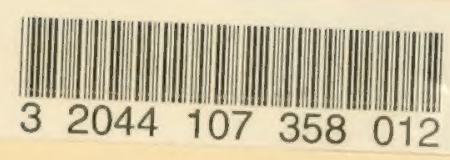


